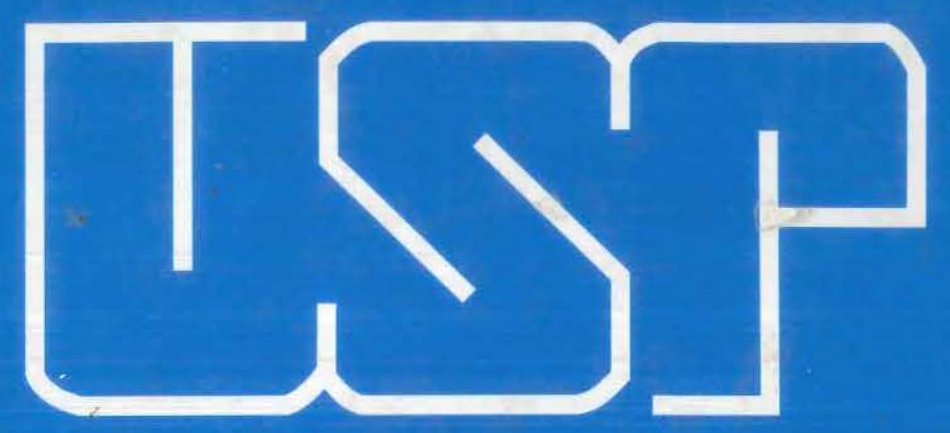

Campus de Săo Carlos

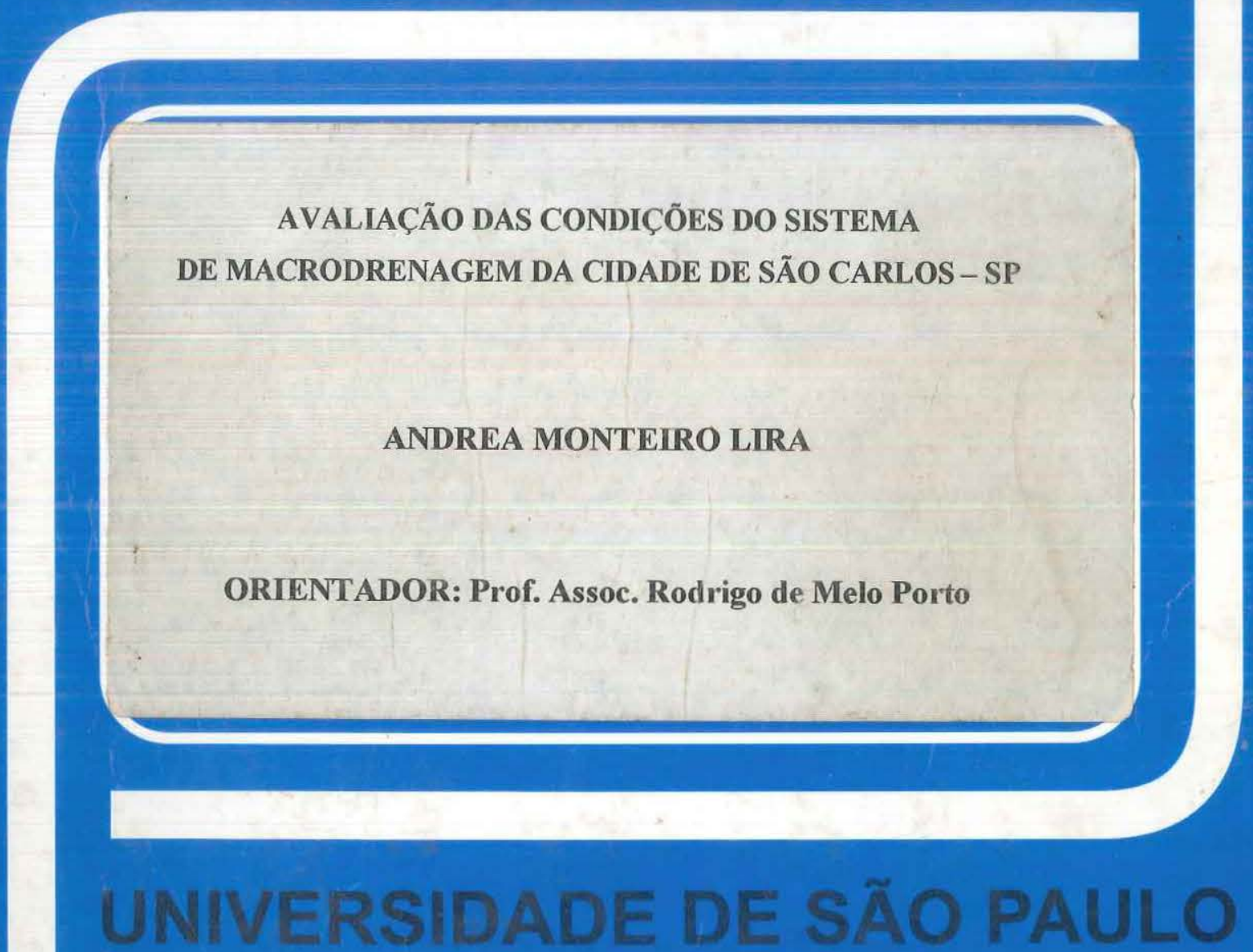

UNIVERSIDADE DE SÃO PAULO

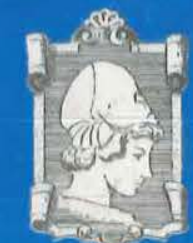

ESCOLA DE ENGENHARIA 
Andrea Monteiro Lira

\section{AVALIAÇÃO DAS CONDIÇÕES DO SISTEMA DE MACRODRENAGEM DA CIDADE DE SÃO CARLOS - SP}

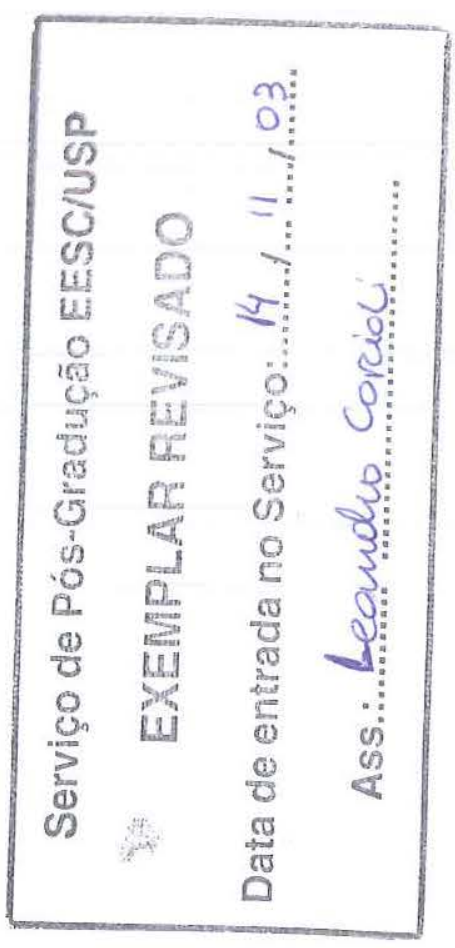

Dissertação apresentada à Escola de Engenharia de São Carlos da Universidade de São Paulo, como parte dos requisitos para a obtenção do Título de Mestre em Hidráulica e Saneamento.

Orientador: Prof. Associado Rodrigo de Melo Porto
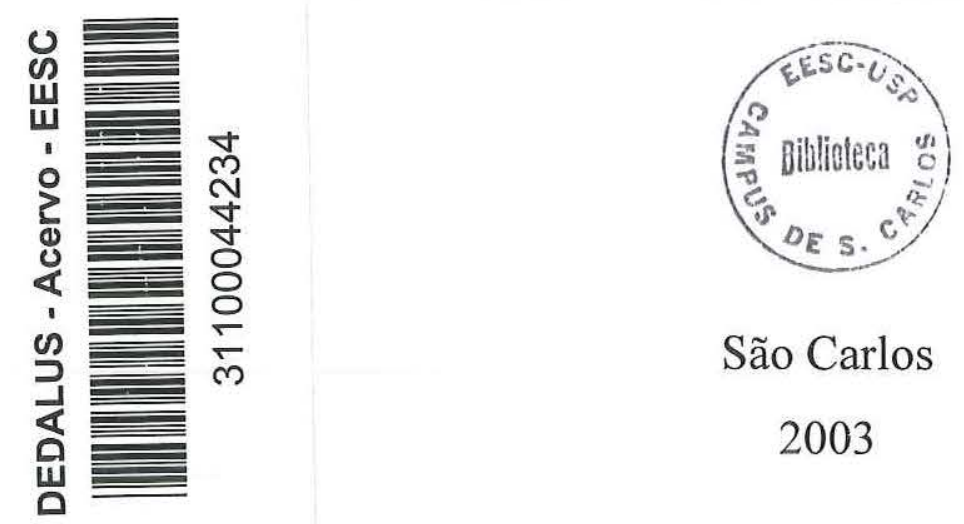

São Carlos 
Dissertação (Mestrado) -- Escola de Engenharia de São Carlos-Universidade de São Paulo, 2003.

Área: Hidráulica e Saneamento.

Orientador: Prof. Assoc. Rodrigo de Melo Porto.

1. Controle de enchentes. 2. Drenagem urbana. 3. Diagnóstico. 4. Urbanização. I. Título. 
FOLHA DE JULGAMENTO

Candidata: Engenheiro ANDREA MONTEIIRO LIRA

Dissertação defendida e julgada em 12-09-2003 perante a Comissão Julgadora:

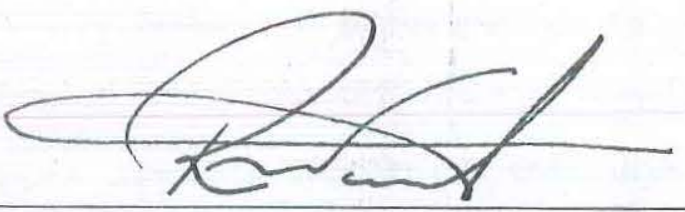

Prof. Assoc. RODRIGO DE MELO PORTO (Orientador)

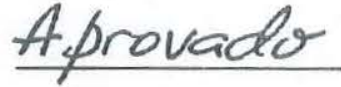

(Escola de Engenharia de São Carlos/USP)
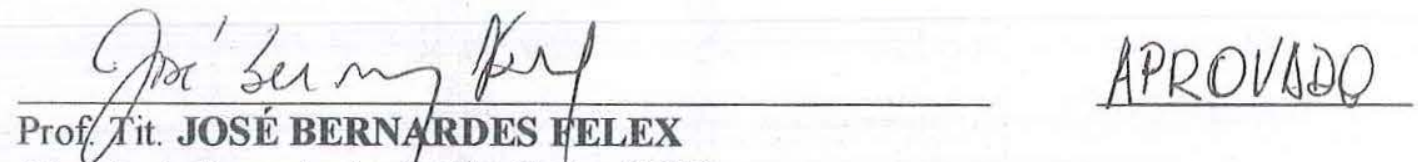

(Escola de Engenharia de São Carlos/USP)

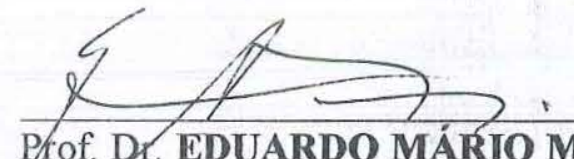

(Escola de Engenharia de São Carlos/USP)

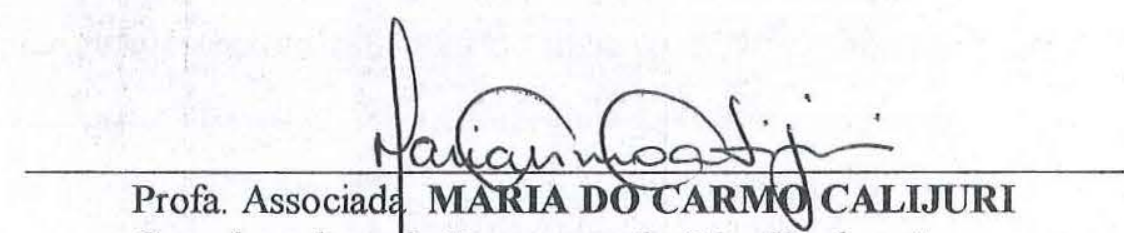

Coordenadora do Programa de Pós-Graduação em

Engenharia (Hidráulica e Saneamento) e

Presidente da Comissão de Pós-Graduação 


\section{PEGADAS NA AREIA}

"Uma noite eu tive um sonho...

Sonhei que estava andando na praia com o Senhor, e através do céu, passavam cenas da minha vida. Para cada cena que se passava, percebi que eram deixados dois pares de pegadas na areia: um era o meu e o outro era do senhor.

Quando a última cena da minha vida passou diante de nós, olhei para trás, para as pegadas na areia, e notei que muitas vezes, no caminho da minha vida, havia apenas um para de pegadas na areia. Notei também que isso aconteceu nos momentos mais difíceis e angustiosos do meu viver. Isso aborreceu-me deveras e perguntei então ao Senhor:

- Senhor, tu me disseste que, uma vez que resolvi te seguir, tu andarias sempre comigo, em todo o caminho. Contudo, notei que durante as maiores atribulações do meu viver, havia apenas um par de pegadas na areia. Não compreendo por que nas horas em que eu mais necessitava de ti, tu me deixaste sozinho.

O Senhor me respondeu:

- Meu querido filho. Jamais eu te deixaria nas horas da prova e do sofrimento. Quando viste, na areia, apenas um par de pegadas, eram as minhas.

Foi exatamente aí que eu te carreguei nos braços". 
Dedico este trabalho primeiramente a Deus que iluminou os meus passos, e em seguida, aos meus pais e avós maternos que são pessoas distintas e essenciais na minha trajetória de vida, sem os quais eu não teria conquistado este título. 


\section{AGRADECIMENTOS}

Ao professor, orientador Rodrigo de Melo Porto, pela excelente colaboração e dedicação durante toda a elaboração deste trabalho.

Ao Conselho Nacional de Desenvolvimento Científico e Tecnológico (CNPq), pela bolsa de estudo concedida.

Aos demais professores da EESC/USP e em especial aos Profs. Drs. do Departamento de Hidráulica e Saneamento Eduardo Mário Mendiondo, Edson Cezar Wendland, Swami Marcondes Villela e Luisa Fernanda Ribeiro Reis pelo apoio prestado.

A todos os funcionários da EESC/USP, especialmente aos do Departamento de Hidráulica e Saneamento, que se disponibilizaram nas horas mais precisas.

Aos amigos da EESC/USP, principalmente aos do laboratório de simulação numérica, a Regina Mambeli Barros e a Rafael Lucio Esteves pela atenção e apoio na conclusão desta dissertação.

A Raphael Machado, aluno de Engenharia Elétrica desta escola, que me auxiliou na compreensão da linguagem do programa utilizado neste estudo.

A Prefeitura Municipal de São Carlos que forneceu dados quando possível.

Aos meus pais José Valter Lira e Rachel Monteiro Lira, pelo amor e apoio, e pela confiança que depositaram em mim neste mestrado e essencialmente, pela educação que me deram.

Aos meus irmãos Adriana Monteiro Lira e José Valter Lira Filho, pelo carinho e confiança.

A minha irmã Ana Rachel Monteiro Lira Tomaz, ao seu marido Geraldez Tomaz Filho e aos sobrinhos Ana Beatriz e Lucas, um carinho especial pelo incentivo.

Aos meus familiares pela confiança e apoio financeiro, e em especial aos meus avós maternos Evandro Maciel Monteiro e Valderez Pinto Monteiro, que sempre estiveram e estarão presentes na minha vida, e também por considerá-los meus pais.

Ao meu noivo Océlio Queiroga Cartaxo Filho pelo companheirismo, cumplicidade e principalmente, pelo incentivo de todas as horas, e também aos seus familiares. 


\section{SUMÁRIO}

LISTA DE FIGURAS.............................................................................. i

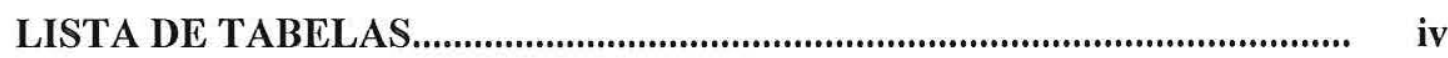

LISTA DE SIGLAS................................................................................. vi

RESUMO_............................................................................................ vii

ABSTRACT .......................................................................................................... viii

1 INTRODUÇÃO...................................................................................

2 OBJETIVOS.................................................................................

2.1 Objetivo Geral.......................................................................................... 5

2.2 Objetivos Específicos................................................................................ 5

3 REVISÃO BIBLIOGRÁFICA....................................................................

3.1 Introdução.................................................................................................... 7

3.2 Processo de urbanização e impactos ambientais.................................................. $\quad 10$

3.3 Urbanização da cidade de São Carlos................................................................. 15

3.4 Sistemas de drenagem urbana.................................................................... 20

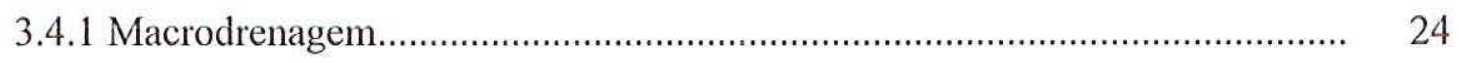

3.4.2 Microdrenagem................................................................................ 28

3.4.3 Plano diretor de São Carlos.......................................................................... 28

3.5 Controle de inundações urbanas........................................................................ 30

3.5.1 Medidas estruturais.................................................................................. 33

3.5.2 Medidas não-estruturais.......................................................................... 36

3.5.3 Controle de inundação com obras hidráulicas................................................. 37

3.6 Escoamento superficial.............................................................................. 37

3.6.1 Modelos de escoamento superficial............................................................ $\quad 39$

3.6.2 Componentes do hidrograma...................................................................... 41 
3.6.3 Modelos para simulações de hidrogramas de cheias........................................ 45

3.6.3.1 Modelo SCS............................................................................................ 45

3.6.3.2 Modelo de regionalização de Diaz e Tucci.................................................... 51

3.6.3.3 Método de Snyder....................................................................................... 54

3.6.3.4 Método de Nash........................................................................................ 56

3.6.3.5 Método de Gray................................................................................... 58

3.7 Modelos hidrológicos................................................................................... 59

3.7.1 Modelo ABC ............................................................................................... 65

3.7.2 Modelo ABC 4........................................................................................ 66

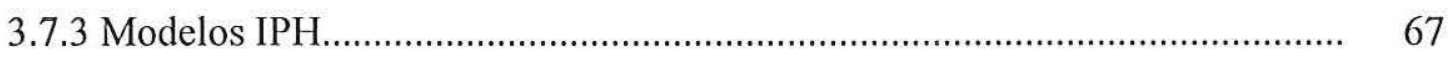

4 MATERIAIS E MÉTODOS................................................................. 69

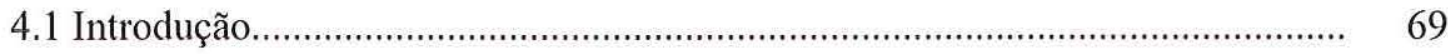

$4.2 \mathrm{O}$ modelo EESC.................................................................................................... 71

4.2.1 Configuração da rede de drenagem............................................................ 72

4.2.2 Transformação chuva-vazão..................................................................... 73

4.2.3 Propagação de cheia............................................................................... 78

4.3 Utilização do modelo EESC........................................................................... 80

4.4 Modificação do modelo EESC........................................................................ 83

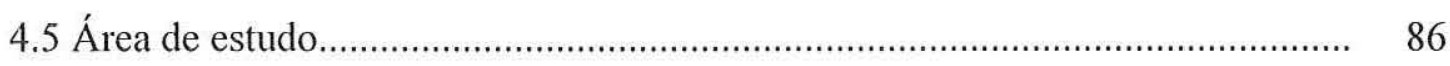

4.5.1 Características gerais do município de São Carlos...................................... 88

4.5.2 Caracterização das bacias de estudo........................................................... 88

4.5.3 Tipo de solo do município de São Carlos...................................................... 92

4.5.4 Uso do solo urbano de São Carlos................................................................... 93

4.5.5 Infra-estrutura do município de São Carlos...................................................... 94

5 RESULTADOS E DISCURSSÕES............................................................. 97

5.1 Discretização da Bacia do Monjolinho........................................................... 97

5.2 Alterações dos parâmetros................................................................................ 98

5.3 Simulações............................................................................................... 100 
5.4 Hidrograma observado.............................................................................. 114

5.4.1 Levantamento da curva-chave da seção do Mercado Municipal...................... 119

5.4.2 Levantamento da curva-chave da seção do Fórum......................................... 121

5.4.3 Ajuste dos parâmetros do modelo EESC......................................................... 124

5.4.4 Verificação do modelo EESC......................................................................... 127

6 CONCLUSÕES E RECOMENDAÇÕES....................................................... 132

6.1 Conclusões.......................................................................................... 132

6.2 Recomendações....................................................................................... 134

ANEXO A - Temas estruturados dos debates para elaboração do Plano Diretor de São Carlos................................................................................................... 138

ANEXO B - Relatório Pólis de São Carlos e Conferência da Cidade - CDROM..................................................................................................

ANEXO C - Rede de macrodrenagem de São Carlos - Sem modificações.......

ANEXO D - Rede de macrodrenagem de São Carlos - Com modificações.....

ANEXO E - Programa do modelo EESC - Subrotina Nash e subrotina Diaz e Tucci.

ANEXO F - Arquivos de entrada.

176

ANEXO G - Programa do modelo EESC - Disquete

ANEXO H - Perfil da seção utilizada neste estudo e retirada do relatório elaborado pelo escritório de consultoria e projetos de engenharia ltda - Shs.. 


\section{LISTA DE FIGURAS}

FIGURA 1 - Seqüência de passos de um estudo de drenagem urbana.

FIGURA 2 - Distribuição percentual das populações urbana e rural no Brasil entre 1940 e 2000.

FIGURA 3 - Processos que ocorreram numa área urbana.

FIGURA 4 - Localização do município de São Carlos no Estado de São Paulo....

FIGURA 5 - Expansão urbana de São Carlos.

FIGURA 6 - O gerenciamento da drenagem e as suas inter-relações.

FIGURA 7 - Canalização de uma parte do Córrego do Tijuco Preto, na marginal, em frente a USP

FIGURA 8 - Canalização de um trecho do Córrego do Gregório, ao lado do Mercado Municipal.

FIGURA 9 - Hidrograma tipo.

FIGURA 10 - HU Sintético de Snyder.

FIGURA 11 - Modelo Nash - Cascata em reservatórios.

FIGURA 12 - Metodologia de um processo de simulação.

FIGURA 13 - Configuração de uma bacia de drenagem.

FIGURA 14 - Hidrograma Unitário Sintético Triangular.

FIGURA 15 - Posicionamento dos parâmetros do HU regionalizado de Diaz e Tucci

FIGURA 16 - Especificação das seções RM 1 a RM 9 do trecho 13, tramo 1, entre as seções 1.12 e 1.13 do Rio Monjolinho (RM).

FIGURA 17 - Representação de uma seção transversal genérica, com 3 níveis d'água

FIGURA 18 - Mapa do Município de São Carlos, com a especificação das microbacias hidrográficas. 
FIGURA 19 - Bacia do Monjolinho.

FIGURA 20 - Trecho canalizado do Córrego do Gregório, na região central de São Carlos.

FIGURA 21 - Trecho do Córrego do Gregório, na região do Mercado Municipal, a mais atingida pelas enchentes

FIGURA 22 - Região central de São Carlos, onde as áreas comerciais (Padaria Caiçara) são mais atingidas pelas enchentes (Córrego do Gregório).

FIGURA 23 - Área residencial atingida pelas enchentes (proteção contra enchentes)

FIGURA 25 - Uso do solo na área urbana de São Carlos.

FIGURA 26 - Área urbana de São Carlos, com as condições de infra-estrutura da cidade.

FIGURA 27 - Hidrogramas de cheia da sub-bacia 35, que representa a área de montante da Bacia do Tijuco Preto

FIGURA 28 - Hidrogramas de cheia da sub-bacia 41, sem modificações.

FIGURA 29 - Hidrogramas de cheia da seção 6.2, com modificações.

FIGURA 30 - Hidrogramas de cheia da sub-bacia 49, sem modificações.

FIGURA 31 - Hidrogramas de cheia da seção 8.2, com modificações.

FIGURA 32 - Hidrogramas de cheia da seção 7.2, sem modificações

FIGURA 33 - Hidrogramas de cheia da seção 11.2, com modificações.

FIGURA 34 - Hidrogramas de cheia da seção 1.7.

FIGURA 35 - Hidrogramas de cheia da seção 1.7, com alteração no PP e N.

FIGURA 36 - Hidrogramas de cheia da seção 2.3.

FIGURA 37 - Hidrogramas de cheia da seção 2.3, com alteração no PP e N........

FIGURA 38 - Influência do número de deflúvio na vazão de pico, para TR = 10 anos. 
FIGURA 39 - Influência do número de deflúvio na vazão de pico, para TR $=25$ anos.

FIGURA 40 - Influência do número de deflúvio na vazão de pico, para TR $=50$ anos.

FIGURA 41 - Foto aérea da região do Mercado Municipal, onde foram coletados os dados de MACHADO (1981).

FIGURA 42 - Foto aérea da região do Fórum, onde foram coletados os dados de SILVA (2003).

FIGURA 43 - Posto 5 ao longo do Córrego do Gregório, próximo ao Fórum........

FIGURA 44 - Córrego do Gregório - Seção de medição do Mercado Municipal.

FIGURA 45 - Curva-Chave do Córrego do Gregório, na seção do Mercado Municipal.

FIGURA 46 - Curva-chave na seção do posto 5 do Córrego do Gregório.

FIGURA 47 - Perfil correto da seção de medição dos dados para a curva-chave do trabalho de Silva (2003).

FIGURA 48 - Cuva-chave utilizada neste trabalho, a partir dos dados de Silva (2003)

FIGURA 49 - Hidrogramas calculados e hidrograma observado para a seção do Mercado Municipal.

FIGURA 50 - Hidrogramas calculados e hidrograma observado para a seção do Fórum

FIGURA 51 - Hidrogramas calculados para a seção do Fórum, com TR $=5$ anos.

FIGURA 52 - Hidrogramas calculados para a seção do Fórum, com TR = 10 anos.....

FIGURA 53 - Hidrogramas calculados para a seção do Fórum, com TR $=25$ anos.

FIGURA 54 - Hidrogramas calculados para a seção do Fórum, com TR $=50$ anos.

FIGURA 55 - Hidrogramas calculados para a seção do Mercado Municipal, com $\mathrm{TR}=25$ anos.

FIGURA 56 - Hidrogramas calculados para a seção do Mercado Municipal, com $\mathrm{TR}=50$ anos 


\section{LISTA DE TABELAS}

TABELA 1 - População Residente, por situação do domicílio e por sexo no Brasil entre 1940 e 2000

TABELA 2 - Causas e efeitos da urbanização sobre as inundações urbanas...........

TABELA 3 - Evolução populacional do município de São Carlos entre 1940 e 2000

TABELA 4 - Medidas estruturais.

TABELA 5 - Resumo das características dos modelos de escoamento.

TABELA 6 - Valores do parâmetro $\mathrm{CN}$ para bacias rurais

TABELA 7 - Valores de CN para bacias urbanas e suburbanas.

TABELA 8 - Correção de CN para outras condições iniciais de umidade

TABELA 9 - Grupos analisados

TABELA 10 - Equações dos diferentes grupos

TABELA 11 - Valores de "n" para cada trecho

TABELA 12 - Número de seções por trecho em relação ao córrego

TABELA 13 - Valores de $\alpha$ e $\beta$ de toda a rede de macrodrenagem de São Carlos.

TABELA 14 - Valores das variáveis utilizadas no arquivo SUBDAD para as sub-bacias criadas.

TABELA 15 - Valores das vazões de pico para os três métodos com o referente tempo, sub-bacia 35 .

TABELA 16 - Valores da vazão de pico para os três métodos com o referente tempo, sub-bacia 41 e seção 6.2

TABELA 17 - Valores da vazão de pico associado ao tempo para os três métodos, sub-bacia 49 e seção 8.2 .

TABELA 18 - Valores da vazão de pico associado ao tempo para os três métodos, seções 7.2 e 11.2 . 
TABELA 19 - Valores da vazão de pico associado ao tempo para os três métodos, seção 1.7 .

TABELA 20 - Valores da vazão de pico associado ao tempo para os três métodos, seção 2.3 ...

TABELA 21 - Descarga para cada evento medido.

TABELA 22 - Valores da vazão de pico associado ao tempo para os três métodos e para os hidrogramas observados 1 e 2 .

TABELA 23 - Valores da vazão de pico associado ao tempo para os três métodos, na seção do Fórum

TABELA 24 - Valores da vazão de pico associado ao tempo para os três métodos, na seção do Mercado Municipal. 


\section{LISTA DE SIGLAS}

ABNT - Associação Brasileira de Normas Técnicas

ABRH - Associação Brasileira de Recursos Hídricos

APP - Área de Preservação Permanente

CNPq - Conselho Nacional de Desenvolvimento Científico e Tecnológico

CDCC - Centro de Divulgação Científica e Cultural

DAEE - Departamento de Águas e Energia Elétrica

EESC - Escola de Engenharia de São Carlos

FEPASA - Ferrovia Paulista SA

HU - Hidrograma Unitário

HUI - Hidrograma Unitário Instantâneo

HUS - Hidrograma Unitário Sintético

HUT - Hidrograma Unitário Triangular

HUST - Hidrograma Unitário Sintético Triangular

IBGE - Instituto Brasileiro de Geografia e Estatística

SCS - Soil Conservation Service

USP - Universidade de São Paulo 


\section{RESUMO}

LIRA, A. M. (2003). Avaliação das Condições do Sistema de Macrodrenagem da Cidade de São Carlos - SP. Dissertação (Mestrado) - Escola de Engenharia de São Carlos, Universidade de São Paulo, São Carlos, 2003.

Devido às conseqüências, cada vez mais freqüentes, provocadas por enchentes ao longo da história da cidade de São Carlos, SP, houve grande interesse em analisar as áreas mais afetadas desta cidade, pois as inundações atingem a população de forma intensa e provoca prejuízos sociais e econômicos. Entre essas razões o crescimento da urbanização pode ser apontado como causa da intensa modificação no uso do solo, que diminui a infiltração e aumenta o volume de escoamento superficial, tendo como conseqüência alterações no ciclo hidrológico. Em consideração a todas essas questões, este trabalho visa contribuir na avaliação das condições de urbanização e seu impacto nos hidrogramas de cheias em pontos críticos da área urbana de São Carlos. Além disso, este estudo pretende subsidiar novos projetos, bem como na verificação hidráulica das estruturas de macrodrenagem, focalizando o Plano Diretor de Drenagem Urbana desta cidade. O modelo EESC foi utilizado para determinar hidrogramas de cheias, através de três metodologias estabelecidas, mais especificamente o método de Nash, o do Soil Conservation Service (SCS) e o método de regionalização de Diaz e Tucci. Como resultados, algumas sugestões foram feitas na condição de auxiliar projetos de engenharia do sistema de macrodrenagem, buscando a segurança e bem estar da população e eficiência dos sistemas.

Palavras-chave: controle de enchentes; drenagem urbana; diagnóstico; urbanização. 


\section{ABSTRACT}

LIRA, A. M. (2003). Evaluation of the Macrodrainage Conditions in the City of São Carlos - SP. M.Sc. Dissertation - Escola de Engenharia de São Carlos, Universidade de São Paulo, São Carlos, 2003.

São Carlos City, State of São Paulo, Brazil, has been struck by flood events. Several are the reasons why such floods have become more and more frequent, contributing to socials and economics damages. Among these reasons one that can be pointed out is the increase of urbanization, which causes intense modifications in the soil use, decreases the infiltration and increases the runoff and, consequently, changes the hydrological cycle. This work aims to contribute to the evaluation of the conditions of urbanization and its impacts on the floods hydrographs in critical points of the urban area of São Carlos. The main purpose of the study is to provide technical information for new projects as well as for the hydraulic verification of the existing macrodrainage structures, focusing on the master plan of urban drainage of the city. The EESC model was used to determine the floods hydrographs by three established methods, more specifically the method of Nash, SCS (Soil Conservation Service) and the regionalization method of Diaz and Tucci. As a result, some suggestions have been made in order to guide engineering projects of macrodrainage system, which seek for the safety and welfare of the population and the efficiency of the systems.

Keywords: control of inundations; urban drainage; diagnosis; urbanization. 


\section{INTRODUÇÃO}

No início do século $\mathrm{XX}$, houve um rápido aumento da população urbana no mundo, principalmente nos países em desenvolvimento, onde o processo de urbanização começou a se acentuar na década de 60. Nos países desenvolvidos, não foi tão acentuado quanto nos países subdesenvolvidos, pois esse processo já se havia iniciado desde a década de 30 .

Os municípios brasileiros apresentaram, ao longo dos anos, um crescimento significativo da população urbana que devido às migrações dentro do país, principalmente a fuga do homem do campo para as cidades, levou ao crescimento desordenado e diversificação social de sua população. Este crescimento gerou grandes metrópoles em capitais de Estados brasileiros e estas regiões metropolitanas possuem um núcleo principal e várias cidades circunvizinhas, decorrência do desenvolvimento urbano.

A urbanização intensificou as alterações e transformações do uso e ocupação do espaço e os efeitos por ela gerados fazem-se sentir sobre todo o aparelhamento urbano relativo a recursos hídricos: abastecimento de água, transporte e tratamento de esgotos sanitários e drenagem pluvial que, por sua vez, causam marcas permanentes nos processos de infiltração e drenagem de áreas urbanizadas.

As cidades brasileiras despreparadas, do ponto de vista da oferta adequada de infra-estruturas urbanas, de moradia e, até mesmo de empregos, estão enfrentando sérios problemas com inundações esporádicas em suas malhas urbanas, que causa os mais variados prejuízos, desde vidas humanas até destruições de infra-estruturas urbanas de pavimentação, redes de água, esgoto, energia elétrica, etc.

A taxa de crescimento significativo da população, e por conseqüência o aumento das superfícies impermeáveis da bacia, pela pavimentação das ruas e calçadas, pelos 
telhados e áreas de estacionamento, vem apresentando um grande problema para as médias e grandes cidades brasileiras.

A impermeabilização reduz significantemente o volume de infiltração das chuvas, motivo pelo qual aumenta o escoamento superficial que ocasiona um hidrograma de cheia com pico maior e prematuro.

Como a falta de planejamento na área urbana é intensa no País, se torna fundamental a existência de sistemas de drenagem urbana que funcionem de maneira eficiente, para garantir o escoamento das massas líquidas, a segurança e o bem-estar da população, pois são evidentes os sérios problemas que a falta ou ineficiência desses podem trazer aos municípios.

A implantação de uma política de intervenção de controle de inundações, de caráter não-estrutural, como planejamento e disciplinamento do uso do solo nas áreas inundáveis e de encostas, e medidas de retenção e detenção do escoamento superficial, são necessárias para o processo de redução de inundações urbanas. Além disso, também se pode optar por medidas estruturais, como ampliações de seções, retificação de córregos, construção de diques, etc., só que estas medidas têm um custo elevado e são de longo prazo.

Há muito tempo o objetivo principal da drenagem urbana foi remover as águas pluviais em excesso da forma mais eficiente possível para evitar transtornos, prejuízos e riscos de inundações, por isso, as ações concentram-se na execução de projetos e obras e na análise econômica dos benefícios e custos dessas medidas estruturais. Essas medidas, além de onerosas, não representam por si só solução eficaz e sustentável dos problemas mais complexos de drenagem urbana.

Para melhores soluções desses problemas é necessária a compreensão mais integrada do meio urbano e das relações entre os sistemas que o compõem. A existência de cadastro confiável das redes de água, esgoto e sistemas de drenagem, serviço de limpeza pública adequado, pavimentação das vias públicas, vontade política de buscar soluções são alguns dos fatores fundamentais para se ter a solução do problema. Bem como, a atuação mais abrangente por parte dos responsáveis pelo setor que necessariamente deve envolver aspectos legais, institucionais, tecnológicos e sociológicos.

Portanto, pode-se dizer que os problemas que afetam os sistemas de drenagem urbana só serão minimizados quando houver gerenciamento adequado dos mesmos, o 
que permitirá melhor utilização do dinheiro público e menores prejuízos.

O município de São Carlos está localizado nas cabeceiras do Rio Monjolinho que possui nessa região, como afluente principal, o Córrego do Gregório, que atravessa a parte mais densa da cidade.

Devido à grande expansão da cidade de São Carlos, a rede de drenagem tornouse ineficiente em vários locais. Apenas o trecho do Córrego do Gregório que atravessa a parte central da cidade está canalizado e, com isso, as canalizações dos córregos passaram a ser prioritárias e estão sendo iniciadas.

Os estudos de cheias urbanas têm-se intensificado com ênfase para análise e desenvolvimento de modelos hidrológicos, estudos de avaliação e adaptação de medidas estruturais e medidas não estruturais as nossas condições urbanísticas e sociais.

Neste trabalho, as técnicas hidrológicas de drenagem urbana aplicam-se a bacias hidrográficas de pequeno porte, que para o cálculo das vazões de cheia se utiliza o método racional, pois as hipóteses deste método adequam-se às características de comportamento hidrológico destas bacias hidrográficas, mas para este estudo se aplicou a técnica baseada na teoria do Hidrograma Unitário (HU), porque esta permite considerar a variação da intensidade de chuva no tempo e o amortecimento na bacia.

O uso da técnica do Hidrograma Unitário Sintético (HUS), para determinação dos hidrogramas de projeto, foi considerado por não dispor de séries históricas de registros de vazões urbanas, que possam ser utilizadas neste estudo de macrodrenagem, mas apenas dados de precipitação, mesmo assim com reduzido número de postos.

Diante disso, este trabalho busca traçar algumas diretrizes para o gerenciamento dos sistemas de macrodrenagem urbana da cidade de São Carlos, e será analisada a importância da determinação de parâmetros e da análise da metodologia a ser estudada na solução dos problemas de drenagem urbana nos centros urbanos. Para atingir os objetivos será feita uma aplicação na solução de problemas em pontos críticos de inundação, na cidade de São Carlos.

Os dados levantados foram introduzidos no modelo EESC, que utiliza três metodologias para a obtenção dos hidrogramas de cheias, o método de Nash, o do Soil Conservation Service (SCS) e o método de regionalização de Diaz e Tucci. Os hidrogramas calculados foram comparados entre si e logo em seguida, foram feitas análises críticas entre eles, para poder se determinar qual destes métodos é o mais favorável para a geração dos hidrogramas de cheias. 
Os objetivos propostos neste estudo estão abordados no capítulo 2 e foram executados detalhadamente, visando o aprendizado e conteúdo desta dissertação.

O capítulo de revisão bibliográfica abordou diversos aspectos relacionados à drenagem urbana, que enfatizou os sistemas de macrodrenagem. Alguns itens como impactos da urbanização no ciclo hidrológico, elaboração de plano diretor da cidade de São Carlos, parâmetros e métodos usados para obtenção de hidrogramas, foram apresentados detalhadamente neste capítulo. Além disso, foram citados vários usos dos sistemas alternativos de drenagem para combate às inundações.

A metodologia utilizada no desenvolvimento deste trabalho está representada no capítulo 4, onde apresenta a Bacia Hidrográfica utilizada neste estudo, procurando destacar aspectos e características relacionadas com o sistema de drenagem urbana. Os resultados e discussões dos parâmetros para a obtenção dos hidrogramas e os métodos utilizados para gerar os hidrogramas estão especificados no capítulo 5.

No capítulo 6, se concluiu os resultados obtidos de todo o estudo realizado, as recomendações que ao concluir o trabalho se achou necessário fazer e o que se poderá ser feito futuramente para dar continuidade ao trabalho, complementando-o ainda mais. 


\section{OBJETIVOS}

\subsection{Objetivo geral}

O objetivo geral deste trabalho é contribuir para o aprimoramento das técnicas de projeto do sistema de macrodrenagem da cidade de São Carlos e aperfeiçoar um modelo hidrológico distribuído por sub-bacias para simulação de hidrogramas de enchentes oriundos de precipitação de alta intensidade e curta duração, para bacias urbanas. Além disso, objetiva-se avaliar as condições atuais e futuras da urbanização e seu impacto nos hidrogramas de cheias em vários pontos críticos da área urbana de São Carlos; auxiliar a elaboração de diretrizes de um futuro plano diretor de drenagem urbana, medida altamente recomendável, que constitui estratégia essencial para a obtenção de boas soluções.

O presente trabalho pretende sugerir recomendações, que possam ser utilizadas na execução de sistemas de macrodrenagem de águas superficiais, procurando qualidade de vida da população e dos sistemas.

\subsection{Objetivos específicos}

Os objetivos específicos que levam ao desenvolvimento deste projeto, com o intuito de se alcançar o objetivo geral, consistem em avaliar e diagnosticar os sistemas de macrodrenagem urbana de São Carlos:

- Reavaliar os parâmetros hidráulicos do modelo hidrológico distribuído por subbacias EESC;

- Propor nova discretização do conjunto de sub-bacias, da cidade de São Carlos, para uso do modelo EESC; 
- Analisar métodos para determinação de vazões de projetos nas bacias de cabeceira, pela avaliação e comparação de três métodos para o cálculo do hidrograma unitário;

- Fazer simulações do comportamento hidrológico da bacia para condições atuais e futuras. 


\section{REVISÃO BIBLIOGRÁFICA}

\subsection{Introdução}

De acordo com Tucci (2001, p.25 e 29), apenas na segunda parte do século 20, a Hidrologia, que define como "uma ciência interdisciplinar que tem tido evolução significativa em face aos problemas crescentes, resultados da ocupação das bacias, do incremento significativo da utilização da água e do resultante impacto sobre o meio ambiente do globo", se consolidou, através do desenvolvimento de programas de observação e quantificação sistemática dos diferentes processos que ocorrem no ciclo hidrológico.

A hidrologia evoluiu de uma ciência descritiva e qualitativa, para uma área onde os métodos quantitativos têm sido explorados através de metodologias matemáticas e estatísticas, melhorando de um lado os resultados e de outro explorando melhor as informações existentes e a utilização da hidrologia em recursos hídricos, que estuda o comportamento físico da ocorrência e o aproveitamento da água na bacia hidrográfica, quantifica os recursos hídricos no tempo e no espaço, e avalia o impacto da modificação da bacia hidrográfica sobre o comportamento dos processos hidrológicos.

O pouco planejamento da ocupação do homem na bacia, que visou no passado o mínimo custo e o máximo benefício de seus usuários, sem maiores preocupações com a preservação do meio ambiente, tem ao longo dos anos, com o crescimento demográfico e a exploração da água, deteriorado os recursos naturais. A complexidade dos sistemas hídricos cresceu devido à diminuição da disponibilidade dos recursos hídricos e deterioração da qualidade das águas. Como conseqüência, projetos com múltiplas finalidades tenderam a ser desenvolvidos, além do aumento do interesse público pelo impacto dos aproveitamentos hídricos sobre o meio ambiente. 
O planejamento da ocupação da bacia hidrográfica é uma necessidade numa sociedade com usos crescentes da água, e que tende a ocupar espaços com riscos de inundação, além de danificar o seu meio.

A tendência atual envolve desenvolvimento sustentado da bacia hidrográfica, que implica o aproveitamento racional dos recursos hídricos com o mínimo de dano ao meio ambiente.

$\mathrm{Na}$ área de hidrologia experimental, foram criadas em diferentes países, bacias representativas e experimentais visando ao entendimento e quantificação de processos físicos que ocorrem na bacia, tais como reflorestamento e desmatamento, erosão do solo e escoamento superficial. Os estudos visam a um melhor entendimento desses processos e a embasar o planejamento do uso da bacia hidrográfica.

O desenvolvimento na hidrologia moderna está ligado ao uso da água, ao controle da ação da mesma sobre a população e ao impacto sobre a bacia e o globo terrestre.

A hidrologia aplicada está voltada para os diferentes problemas que envolvem a utilização dos recursos hídricos, preservação do meio ambiente e ocupação da bacia. A utilização de recursos hídricos envolve disponibilidade hídrica, regularização de vazão, planejamento, operação e gerenciamento dos recursos hídricos.

Quanto à preservação do meio ambiente, modificações do uso do solo, regularização para controle de qualidade da água, impacto das obras hidráulicas sobre o meio ambiente aquático e terrestre, são exemplos de problemas que envolvem aspectos multidisciplinares em que a hidrologia tem uma parcela importante.

Segundo Vicentini (2000), a exemplo dos países em desenvolvimento, os estudos da hidrologia urbana devem não só abranger os estudos quantitativos e qualitativos da urbanização no escoamento da bacia como também propor novas soluções e medidas, compatíveis com a situação econômica vigente, de forma a minimizar os efeitos da urbanização na bacia hidrográfica. Diante deste novo paradigma, ganha força o conceito da bacia hidrográfica como unidade de estudo e planejamento, a exemplo do que vem sendo abordado nos comitês de bacias, contudo o Brasil está encaminhando para atingir o grau de desenvolvimento de uma cultura própria de drenagem.

A "hidrologia urbana" pode ser definida como "o estudo dos processos hidrológicos em ambientes afetados pela urbanização, e quando o interesse maior é a 
drenagem urbana o escopo dos estudos pode ser bastante simplificado e geralmente se limita ao estudo das cheias" (TUCCI, 2001, p.811).

Segundo Hall* (1984 apud TUCCI, 2001, p.943), a Figura 1, adaptada de Hall ilustra o procedimento padrão de um estudo de drenagem urbana em 5 passos.

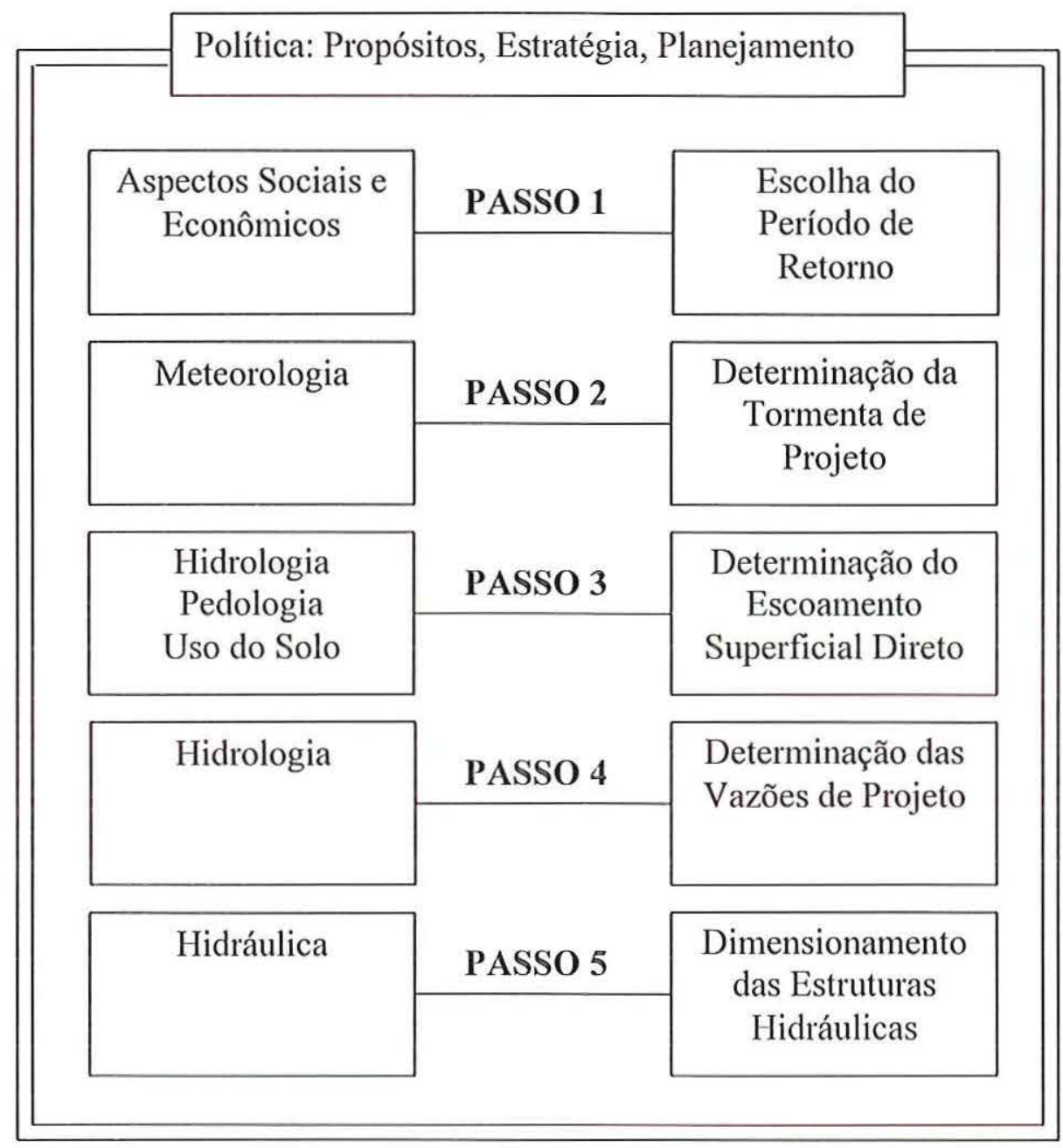

Figura 1 - Seqüência de passos de um estudo de drenagem urbana.

Fonte: Tucci (2001, p.813).

\footnotetext{
* HALL, M.J. (1984). Urban Hydrology. Elsevier Applied Publishers, London and Swindon, UK, p.299 apud TUCCI, C.E.M. (2001). Hidrologia Ciência e Aplicação. Associação Brasileira de Recursos Hídricos (ABRH), Porto Alegre: Ed. Universidade/UFRGS, $2^{\mathrm{a} e d .}$ p.943.
} 
Nessa figura a determinação de projeto, da chuva excedente e do hidrograma de projeto pertencem ao campo da hidrologia urbana. O passo 1, escolha do período de retorno, situa-se em um contexto sócio-econômico, enquanto o passo 5, dimensionamento de estruturas hidráulicas e/ou definição de outras ações, referem-se à fase de projeto das medidas a serem implantadas na bacia. Os processos hidrológicos contidos nos passos 2, 3 e 4 serão limitados em relação aos aspectos de interesse específico da drenagem urbana e apresentados no decorrer deste estudo.

A drenagem urbana no Brasil foi implantada sem nenhuma normatização, e até os dias atuais ainda se verifica que não há convalidação e/ou adoção de uma norma técnica que regulamente os projetos de drenagem urbana, o que existe são tentativas de normas com a publicação de manuais e trabalhos científicos.

O desenvolvimento de modelos matemáticos tem se intensificado nas últimas décadas atingindo um alto grau de desenvolvimento. Estes modelos são desenvolvidos nos grandes centros de pesquisa do país e estão disponíveis aos projetistas, o que permite a realização de simulações nas bacias e obtenção de prognósticos quanto ao seu desenvolvimento urbano.

O país segue uma tendência mundial de desenvolvimento de algoritmos matemáticos, mas pouco se tem feito na obtenção de dados reais para a calibração destes modelos, principalmente para as pequenas bacias urbanas, cuja principal característica é a redução do tempo de resposta da bacia diante da intensificação do processo de urbanização.

\subsection{Processo de urbanização e impactos ambientais}

De acordo com Ferreira (1986) defini-se urbanização como "o fenômeno caracterizado pela concentração cada vez mais densa de população, em aglomerações de caráter urbano".

Segundo Tucci (1995), no Brasil, o processo de urbanização acelerado ocorreu depois da década de 60 , e gerou uma população urbana praticamente sem infraestrutura, principalmente na década de 80 , quando os investimentos foram reduzidos.

Tal fenômeno está relacionado ao abandono do campo devido, principalmente, à industrialização agrícola que gerou desemprego e fez com que ocorresse fuga dos campos para as cidades. Devido a isso, os municípios brasileiros, principalmente os que 
tiveram aumento considerável em sua área urbana tem seus sistemas de infra-estruturas afetados, com o elevado incremento da população urbana.

Na Tabela 1 estão apresentados os dados obtidos pelo Censo Demográfico de 2000, realizado pelo Instituto Brasileiro de Geografia e Estatística (IBGE), onde a percentagem de população urbana no Brasil era em relação ao total 31,24\% em 1940, subiu para 44,67\% em 1960 e entre os anos de 1960 e 1970, quando se iniciaram as migrações no País, verifica-se que no ano de 1970 a população rural caiu para 44,08\% e a população urbana cresceu para $55,92 \%$, já na Figura 2, observa-se claramente a inversão do quadro populacional brasileiro, que os municípios do Brasil tem sofrido nas últimas décadas.

Tabela 1 - População Residente, por situação do domicílio e por sexo no Brasil entre 1940 e 2000.

\begin{tabular}{|c|c|c|c|c|c|}
\hline Ano & $\begin{array}{c}\text { População } \\
\text { Total } \\
\text { (hab) }\end{array}$ & $\begin{array}{c}\text { População } \\
\text { Rural } \\
\text { (hab) }\end{array}$ & $\begin{array}{c}\text { População } \\
\text { Urbana } \\
\text { (hab) }\end{array}$ & $\begin{array}{c}\text { População } \\
\text { Rural } \\
\text { (\%) }\end{array}$ & $\begin{array}{c}\text { População } \\
\text { Urbana } \\
\text { (\%) }\end{array}$ \\
\hline $\mathbf{1 9 4 0}$ & 41.236 .315 & 28.356 .133 & 12.880 .182 & 68,76 & 31,24 \\
\hline $\mathbf{1 9 5 0}$ & 51.944 .397 & 33.161 .506 & 18.782 .891 & 63,84 & 36,16 \\
\hline $\mathbf{1 9 6 0}$ & 70.070457 & 38.767 .423 & 31.303 .034 & 55,33 & 44,67 \\
\hline $\mathbf{1 9 7 0}$ & 93.139 .037 & 41.054 .053 & 52.084 .984 & 44,08 & 55,92 \\
\hline $\mathbf{1 9 8 0}$ & 119.002 .706 & 38.566 .297 & 80.436 .409 & 32,41 & 67,59 \\
\hline $\mathbf{1 9 9 1}$ & 146.825 .475 & 35.834 .485 & 110.990 .990 & 24,41 & 75,59 \\
\hline $\mathbf{1 9 9 6}$ & 157.070 .163 & 33.993 .332 & 123.076 .831 & 21,64 & 78,36 \\
\hline $\mathbf{2 0 0 0}$ & 169.799 .170 & 31.845 .211 & 137.953 .959 & 18,75 & 81,25 \\
\hline
\end{tabular}




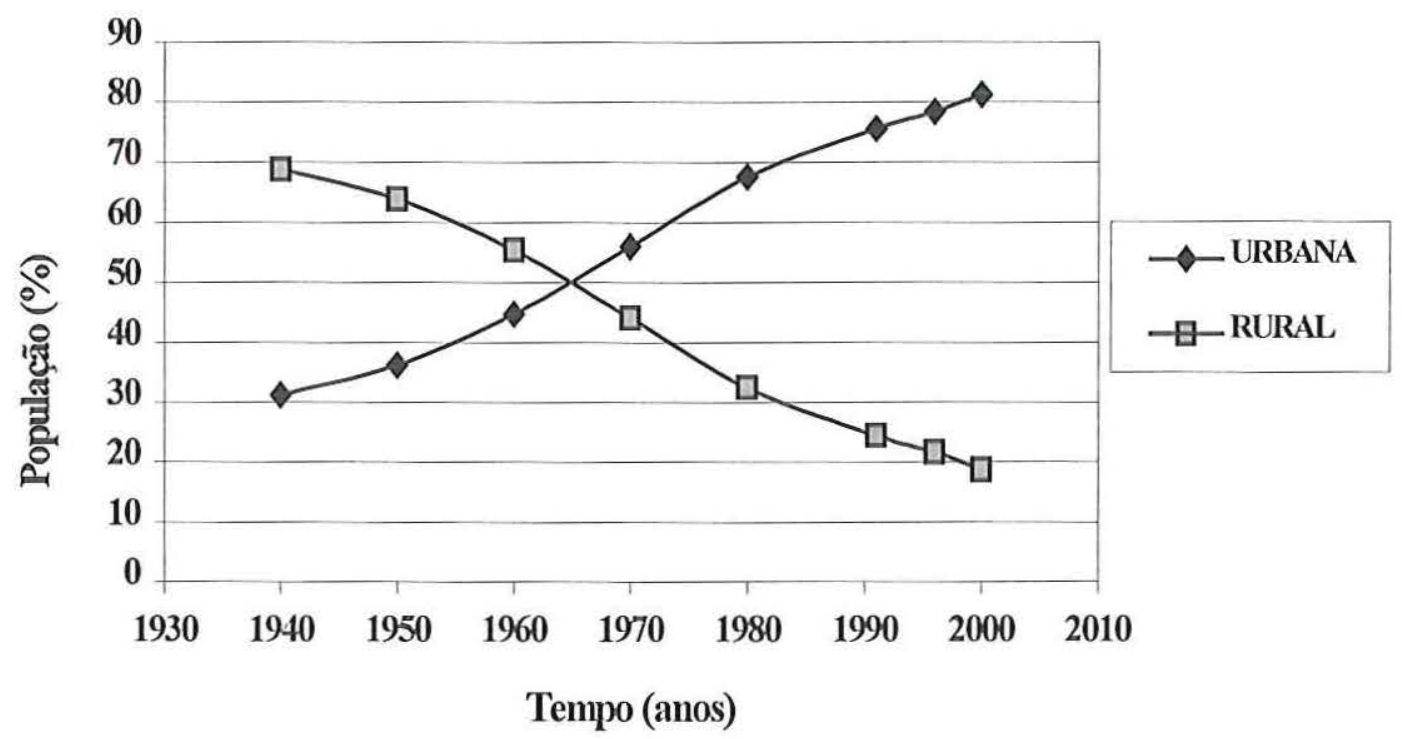

Figura 2 - Distribuição percentual das populações urbana e rural no Brasil entre 1940 e 2000.

Fonte (Tabela 1 e Figura 2): IBGE - Censos Demográficos de 1940 a 2000.

A população procurou habitar zonas mais altas aonde o rio dificilmente chegaria, mas com o crescimento desordenado e acelerado das cidades, as áreas de risco, como as várzeas inundáveis, também foram ocupadas.

A questão com a qual o administrador municipal se defronta com relação à população carente, que ocupa áreas de alto risco de inundações, ao transferir essa população para área mais segura, outros grupos se alojam nos mesmos lugares, como resultado das dificuldades econômicas e das diferenças sociais.

Tucci (1995) afirma que as enchentes nas áreas urbanas são decorrentes de dois processos, cada qual com características próprias: a ocupação das áreas ribeirinhas e a urbanização. O primeiro processo se caracteriza como natural, no qual o rio ocupa o seu leito maior, de acordo com eventos chuvosos extremos. Este leito é ocupado inadequadamente pelo espaço urbano.

O segundo processo tem efeito significativo na resposta hidrológica da área da bacia e conseqüentemente na hidrologia das regiões a jusante. Este efeito é traduzido por aumento do escoamento superficial devido ao aumento das áreas impermeáveis e redução no tempo de resposta da bacia, além disso, reduz a capacidade de recarga dos aqüíferos que produz variações intensas no nível dos cursos d'água. 
A urbanização tende a ocorrer no sentido de jusante para montante na macrodrenagem urbana, devido às características de relevo. Com a impermeabilização do solo através de telhados, ruas e pátios, entre outros, parcela significativa da água que infiltrava nesses locais passa a escoar por condutos e aumenta o escoamento superficial.

De acordo com Tucci (1995), as inundações podem ser provocadas por:

- Estrangulamento da seção do rio por pilares de ponte, estradas, aterros para aproveitamento da área, assoreamento do leito do rio e lixo;

- Remanso devido à macrodrenagem, rio principal, lago, reservatório ou oceano;

- Erros de execução e projeto de drenagem de rodovias e avenidas, entre outros. Adutoras, pontes ou rodovias freqüentemente são projetadas sem que seu impacto sobre a drenagem seja levado em consideração.

Tucci (2001), através da Tabela 2, explicita claramente as relações de causa e efeito da urbanização sobre as inundações urbanas.

Tabela 2 - Causas e efeitos da urbanização sobre as inundações urbanas.

\begin{tabular}{|c|c|}
\hline Causas & Efeitos \\
\hline Impermeabilização & Maiores picos e vazões. \\
Rede de Drenagem & Maiores picos a jusante. \\
Lixo & $\begin{array}{c}\text { Degradação da qualidade da água; } \\
\text { Entupimento de bueiros e galerias. } \\
\text { Redes de esgotos deficientes }\end{array}$ \\
Degradação da qualidade da água; \\
Moléstias de veiculação hídrica; \\
Desmatamento e & Inundações: consequiências mais sérias. \\
Mesenvolvimento Indisciplinado & Maiores picos e volumes; \\
Ocupação das várzeas & Assoreamento em canais e galerias. \\
& Maiores prejuízos; \\
& Maiores picos; \\
& Maiores custos de utilidades públicas. \\
\hline
\end{tabular}

Fonte: Tucci (2001, p.807). 
No entanto, segundo Tucci (2001), a urbanização tem também conseqüências não hidrológicas que interferem significativamente nas questões de drenagem urbana, principalmente se consideradas as condições brasileiras das últimas décadas, marcadas por crescimento acelerado e caótico das populações urbanas. Os impactos mais importantes são citados a seguir:

\section{Conseqüência sobre a ocupação do solo:}

a) Proliferação de loteamentos executados sem condições técnicas adequadas;

b) Ocupação de áreas impróprias (principalmente várzeas de inundação e cabeceiras íngremes);

c) Proliferação de favelas e invasões;

d) Ocupação extensa e adensada dificultando a construção de canalizações e eliminando áreas de armazenamento.

\section{Consequiências do comportamento político e administrativo:}

a) $\mathrm{O}$ crescimento acelerado acirra a disputa por recursos entre os diversos setores da administração urbana e faz prevalecer à tendência de atuar corretivamente em pontos isolados;

b) Medidas para disciplinar a ocupação do solo são dificultadas por conflitos de interesses;

c) Políticas de médio e longo prazo são invariavelmente relegadas a segundo plano.

De acordo com Tucci (2001), a Figura 3, explicitada em Hall (1984), mostra como se inter-relacionam os diversos processos que ocorrem em uma área urbana. 


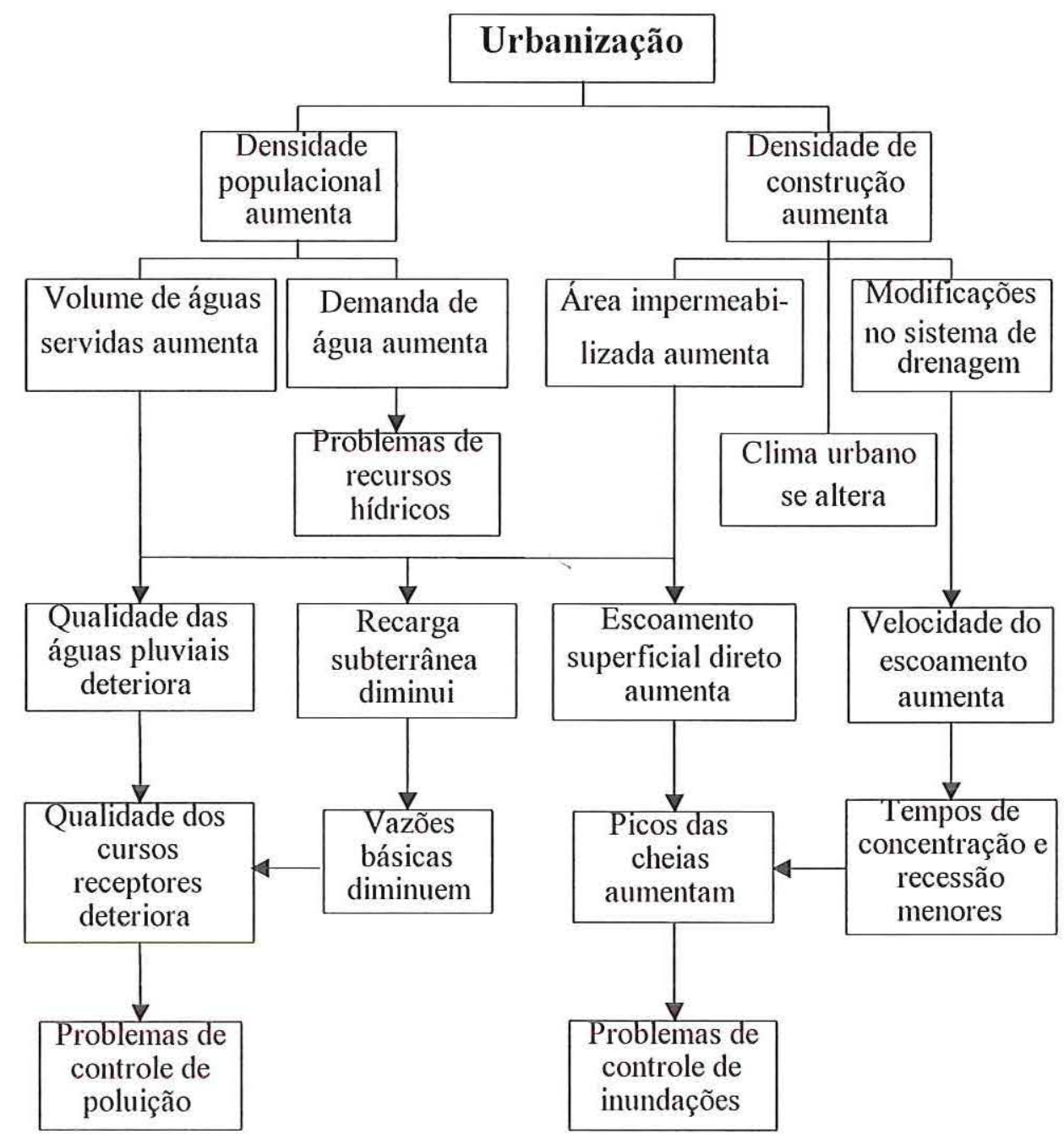

Figura 3 - Processos que ocorreram numa área urbana.

Fonte: Tucci (2001, p.808).

O impacto da urbanização tende a aumentar a necessidade de ampliação da capacidade dos condutos com conseqüente aumento de custos. Normalmente esse processo evolui a partir de pequenas áreas dentro de um contexto de aprovação de loteamentos.

3.3 Urbanização da cidade de São Carlos

As transformações no uso e ocupação do espaço no território, ou seja, as alterações das formas de distribuição da população no território em relação às 
modificações na produção que, com o decorrer dos desdobramentos ocorridos no capitalismo e nos movimentos econômicos locais, apontam para o aumento do tamanho das cidades e para o crescimento e diversificação social de sua população.

A determinação dos vetores de crescimento na região de estudo, onde hoje se encontra o município de São Carlos, é necessária no sentido de avaliar seu efeito no sistema de drenagem urbana da cidade e permitir planejamento do desenvolvimento urbano, de modo a orientar a ocupação do solo e evitar prejuízos muitas vezes incontornáveis, uma vez não previstos.

Assim como outras cidades do oeste paulista, o surgimento e o desenvolvimento de São Carlos esteve vinculado ao ciclo cafeeiro. Com a integração à rede ferroviária, a partir de 1884, a cidade se inseriu mais efetivamente à economia paulista.

Alguns pesquisadores como Devescovi (1987) e Bisinoto (1988), têm enfocado a evolução urbana de São Carlos desde a época colonial, buscando as causas do surgimento, do traçado, do efeito dos vários ciclos econômicos sobre as aglomerações e o processo de afluxo de grande contingente do campo para a cidade.

Segundo Bisinoto ${ }^{*}$ (1988 apud BARBASSA, 1991, p.327) a cidade surgiu com um aglomerado de casas no cruzamento do Córrego do Gregório e o caminho que ligava Piracicaba a Cuiabá. O crescimento se fazia com doações de terras por fazendeiros à igreja, locais que os especuladores lotearam, em pontos que lhes foram convenientes. A construção de meios de transportes, como rodovias e ferrovias, orientou o crescimento urbano. Os transportes coletivos afetaram também a distribuição da cidade. Na época dos bondes, por motivos econômicos, a cidade era adensada; foi o uso de ônibus que espalhou a cidade.

Com a crise do café nos anos 30 do século XX, várias pequenas indústrias faliram e isso aconteceu porque, neste período, as indústrias da capital começaram a concorrer com as do interior. Com a reversão do processo de desconcentração industrial que se deu a partir dos anos 70, as cidades do interior de São Paulo foram beneficiadas com a instalação de indústrias. Na primeira metade da década de 70, a cidade de São Carlos recupera os níveis de participação do início dos anos 40, pois o valor da

\footnotetext{
• BISINOTO, D.A. (1988). Evolução Urbana de São Carlos. Dissertação (Mestrado) - Escola de Engenharia de São Carlos, Universidade de São Paulo (USP), Departamento de Arquitetura. São Carlos, 1988 apud BARBASSA, A.P. (1991). Simulação do Efeito da Urbanização sobre a Drenagem Pluvial na Cidade de São Carlos/SP. 327p. Tese (Doutorado) - Escola de Engenharia de São Carlos - Universidade de São Paulo (USP), Departamento de Hidráulica e Saneamento. São Carlos, 1991.
} 
produção industrial atinge $0,58 \%$ do total estadual, enquanto a população ocupada na indústria são-carlense sobe de $0,55 \%$ para $0,61 \%$, em 1959 .

A exemplo do que aconteceu com outras cidades brasileiras, a população de São Carlos também passou de rural à urbana, como se pode observar na Tabela 3, onde estão apresentados os resultados fornecidos pelo IBGE da evolução da população sãocarlense, através do censo demográfico desde 1940 a 2000.

Tabela 3 - Evolução populacional do município de São Carlos entre 1940 e 2000.

\begin{tabular}{|c|c|c|c|c|c|}
\hline Ano & $\begin{array}{c}\text { População } \\
\text { Total } \\
\text { (hab) }\end{array}$ & $\begin{array}{c}\text { População } \\
\text { Rural } \\
\text { (hab) }\end{array}$ & $\begin{array}{c}\text { População } \\
\text { Urbana } \\
\text { (hab) }\end{array}$ & $\begin{array}{c}\text { População } \\
\text { Rural } \\
\text { (\%) }\end{array}$ & $\begin{array}{c}\text { População } \\
\text { Urbana } \\
\text { (\%) }\end{array}$ \\
\hline $\mathbf{1 9 4 0}$ & 48.609 & 22.863 & 25.746 & 47,03 & 52,97 \\
\hline $\mathbf{1 9 5 0}$ & 47.731 & 15.028 & 32.703 & 31,48 & 68,52 \\
\hline $\mathbf{1 9 6 0}$ & 62.045 & 11.194 & 50.851 & 18,04 & 81,96 \\
\hline $\mathbf{1 9 7 0}$ & 85.425 & 9.686 & 75.739 & 11,34 & 88,66 \\
\hline $\mathbf{1 9 8 0}$ & 119.542 & 9.307 & 110.235 & 7,79 & 92,21 \\
\hline $\mathbf{1 9 9 1}$ & 158.221 & 9.813 & 148.408 & 6,20 & 93,80 \\
\hline $\mathbf{2 0 0 0}$ & 192.923 & 9.554 & 183.369 & 4,95 & 95,05 \\
\hline
\end{tabular}

Fonte: IBGE - Censos Demográficos de 1940 a 2000.

Em 1940, a população rural representava $47,03 \%$ do total da população do município, já nos anos 70, somente 11,34\%. Atualmente, reside na zona rural apenas 4,95\% da população são-carlense. Apesar de possuir um vasto território rural e uma importante estrutura produtiva agrícola, a base econômica do município é urbana, onde se destaca a indústria, o comércio e serviços.

O texto de Perez Junior (2003), relata que a cidade de São Carlos, outrora, chamada de São Carlos do Pinhal, dada a quantidade de pinheiro do Paraná (Araucária), dista 244 km de São Paulo, a 830 metros de altitude em relação ao nível do mar, com $22^{\circ} 02^{\prime \prime}$ de latitude Sul de e $47^{\circ} 52^{\prime \prime}$ de longitude Oeste.

Segundo o Relatório Pólis (2002), esta cidade está situada no centro do Estado de São Paulo, como mostra a Figura 4, com área total de $1.140,90 \mathrm{Km}^{2}$, e a população atual totaliza 192.923 habitantes, sendo que $95,21 \%$ dos habitantes residem na área urbana. 


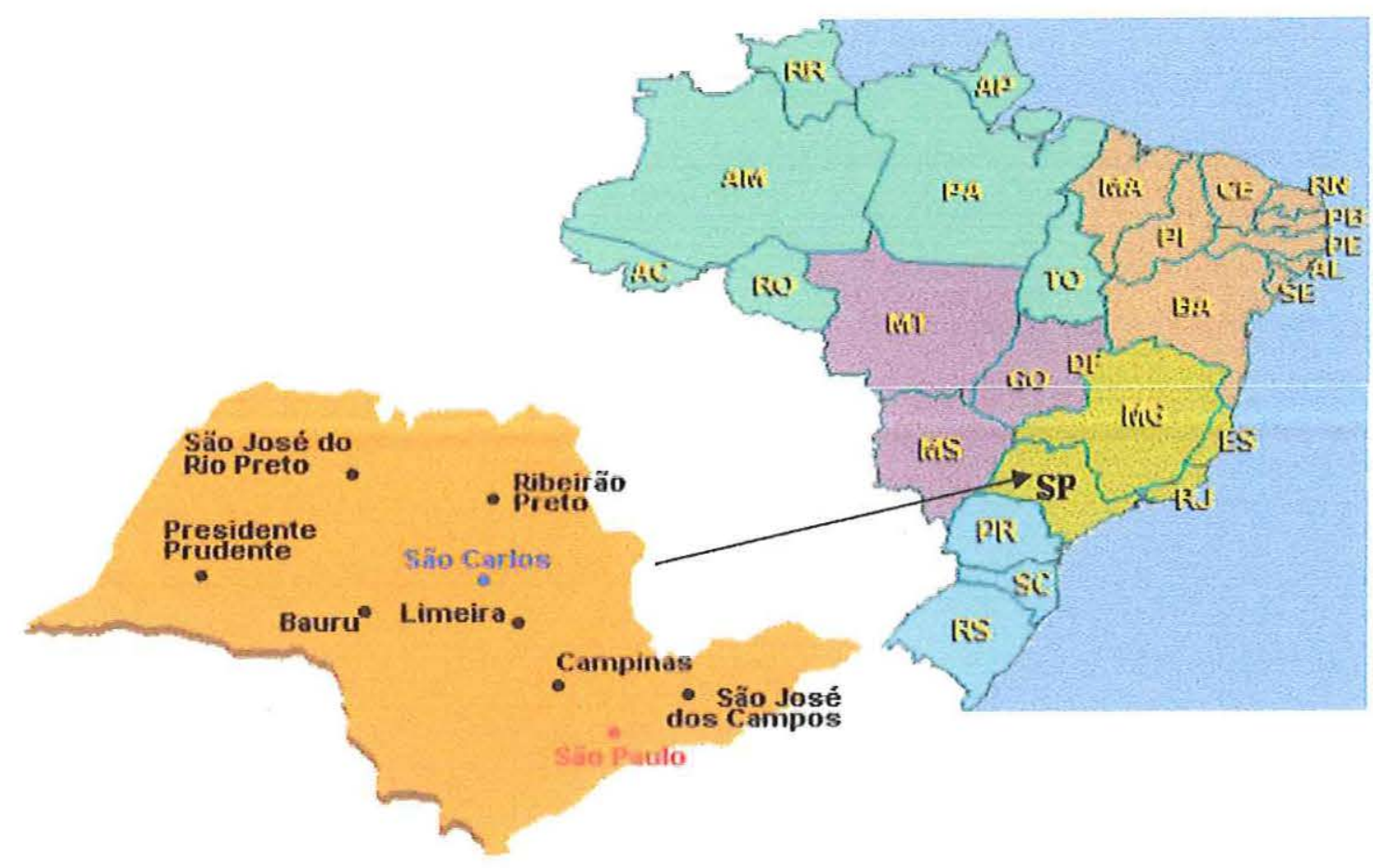

Figura 4 - Localização do município de São Carlos no Estado de São Paulo.

Os municípios confrontantes com a região de São Carlos são Rincão a $58 \mathrm{Km}$ Norte, Araraquara a $45 \mathrm{Km}$ Oeste, Descalvado a $35 \mathrm{Km}$ Leste e Brotas a $60 \mathrm{Km}$ Sul. Essa região é cortada pela Bacia do Rio Mongi-Guaçu e pela Bacia do Tietê-Jacaré. Aquela drena águas para o Rio Pardo e esta, para o Tietê.

A cidade de São Carlos é banhada pelos rios/córregos do Gregório, Monjolinho, Espraiado, Jararaca, Fazzari, Santa Maria do Leme, Paraíso, Tijuco Preto, Pombas, Água Quente, Mineirinho, Medeiros, Matinha, Dois Portões, Ponte de Taboa e Simeão.

A partir dos anos 70, com a instalação da Universidade Federal, nota-se a ocupação para além da área urbana circunscrita pela Rodovia Washington Luiz, na direção norte, nas proximidades da Área de Preservação Permanente (APP), localizada na bacia hidrográfica do Monjolinho, importante produtor de água do município.

De acordo com Aguiar* (1988 apud BARBASSA, 1991, p.327) autor do mapeamento geotécnico de $186 \mathrm{Km}^{2}$ em torno da cidade de São Carlos, avaliou que as

- AGUIAR, R.L. (1988). Mapeamento Geotécnico da Área de Expansão Urbana de São Carlos - SP: Contribuição ao Planejamento. Departamento de Geotecnia, EESC, 1988, 2V. apud BARBASSA, A.P. (1991). Simulação do Efeito da Urbanização Sobre a Drenagem Pluvial na Cidade de São Carlos/ SP. p.327. Tese (Doutorado) - Escola de Engenharia de São Carlos Departamento de Hidráulica e Saneamento, Universidade de São Paulo. São Carlos, 1991. 
regiões sul e sudoeste são de difícil urbanização devido às altas declividades da bacia do Córrego da Água Quente e à presença limitada da rodovia para Ribeirão Bonito.

À nordeste e sudeste, há dois obstáculos ao crescimento urbano: a rodovia Washington Luiz e preservação de mananciais ali existentes. Ao norte e ao oeste tem-se alguns loteamentos aprovados e grande fazendas, sobre os quais recaem regiões de desenvolvimento preferencial.

Através da Figura 5, pode-se perceber a expansão da área urbana com início em 1940 até 2002, e também, do ponto de vista territorial, nos anos 70 acontece uma ruptura na lógica de ocupação da cidade. A ocupação da malha urbana ocorre de forma descontínua e se inicia o processo de ocupação periférica, sem ou com infra-estrutura precária, típica das cidades brasileiras.

Nos anos 80, a ocupação do loteamento popular conhecido como Cidade Aracy, definiu a expansão urbana na direção sudoeste. Com a fixação da população de baixa renda nas áreas suscetíveis à erosão e as Áreas de Preservação Permanente, agravaramse os problemas ambientais e de infra-estrutura na periferia.

$\mathrm{Na}$ direção noroeste, área mais adequada para ocupação do ponto de vista geotécnico e ambiental, localizam-se loteamentos populares, como por exemplo, Santa Angelina, loteamentos de alta renda, o Shopping Center, e o novo campus da USP (Campus II/USP). Observa-se atualmente nessa região a concentração de projetos de alto padrão.

O principal conflito na forma de ocupação do território de São Carlos é de natureza ambiental. A cidade cresceu sobre áreas impróprias, que ocasiona graves problemas de erosão, drenagem e de proteção dos mananciais. Esta situação foi reforçada pela legislação de parcelamento do solo extremamente permissiva, que não exige dos agentes privados a execução de obras de infra-estrutura básica. 


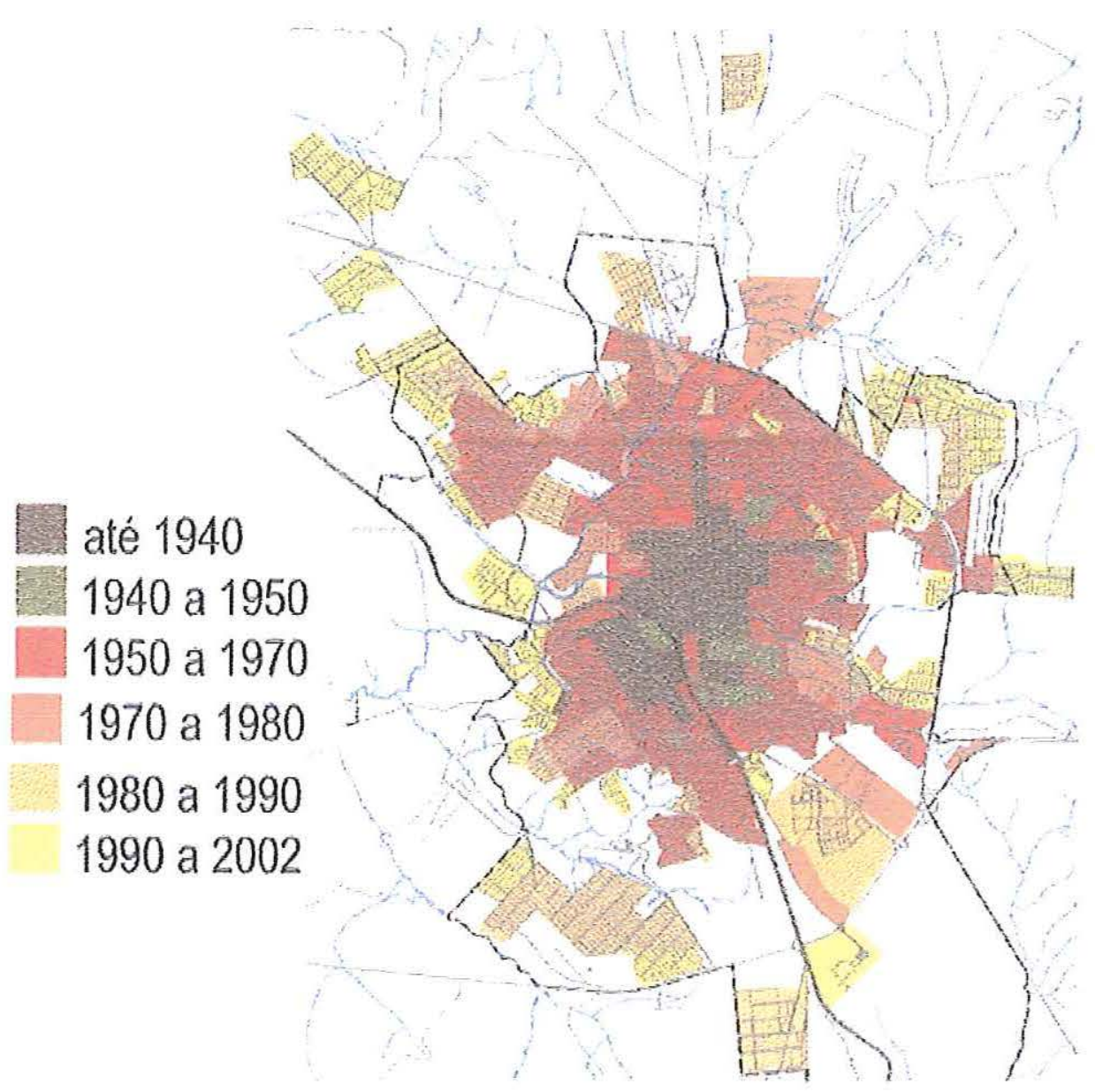

Figura 5 - Expansão urbana de São Carlos.

Fonte: Relatório Pólis (2002, p.21).

\subsection{Sistemas de drenagem urbana}

De acordo com Tucci (2001, p.805), o termo drenagem urbana é entendido, no seu sentido mais amplo, "como o conjunto de medidas que tenham por objetivo minimizar os riscos a que as populações estão sujeitas, diminuir os prejuízos causados por inundações e possibilitar o desenvolvimento urbano de forma harmônica, articulada e sustentável".

Costa Junior (2003, p.32), formulou o conceito de desenvolvimento sustentável, como "aquele que atende as necessidades do presente sem comprometer a possibilidade 
de gerações futuras atenderem as suas próprias necessidades". Ele ainda destaca que a sustentabilidade para alguns autores possui várias abordagens além da econômica e cita que Figueiredo (2000) fala que a sustentabilidade possui cinco dimensões: dimensão social, econômica, ecológica, espacial e cultural.

A estruturação do espaço urbano e neste caso, o processo de implantação dos sistemas de drenagem, deve incorporar esses conceitos relacionados com as diversas dimensões da sustentabilidade, principalmente, a ecológica, econômica e social.

Segundo Costa Junior (2003), a proposição de uma drenagem urbana sustentável é inacessível, pois existe atualmente uma incompatibilidade muito elevada entre a produção e ocupação do meio urbano, e os sistemas de drenagem. Ele ainda cita que Butler e Parkinson (1997) defendem sistemas de drenagem "menos insustentáveis", onde o processo de gerenciamento da drenagem urbana deve se pautar em medidas diversificadas, que utilizem técnicas e tecnologias estruturais e não-estruturais.

As propostas de medidas sustentáveis para a drenagem urbana, segundo Butler e Parkinson (1997), enfatizam o aspecto de controle do escoamento superficial na fonte geradora, através de retenção, detenção e infiltração. Durante muito tempo o objetivo principal da drenagem urbana foi remover as águas pluviais em excesso da forma mais eficiente possível para evitar transtornos, prejuízos e riscos de inundações.

Segundo Tucci (2001), soluções eficazes de drenagem urbana dependem dos seguintes fatores:

- Existência de uma política para o setor que defina objetivos a serem alcançados e os meios (legais, institucionais, técnicos e financeiros) para atingi-los;

- Existência de uma política para ocupação do solo urbano devidamente articulada com a política de drenagem urbana, principalmente no que se refere à ocupação das várzeas de inundação;

- Processo de planejamento que contemple medidas de curto, médio e longo prazos em toda a bacia, e integre as medidas de drenagem de águas pluviais no complexo maior do ambiente urbano;

- Existência de entidade eficiente que domine as tecnologias necessárias, implante obras e medidas, desenvolva atividades de comunicação social, promova a participação pública, estabeleça critérios, aplique leis e normas e, enfim, exerça, de forma positiva, a liderança do setor; 
- Domínio da tecnologia adequada para planejamento, projeto, construção e operação das obras;

- Organização de campanhas de educação e esclarecimento da opinião pública.

Maksimovic e Todorovic ${ }^{*}$ (1998 apud VICENTINI, 2000, p.171), afirmaram que os sistemas de drenagem são partes integrantes da infra-estrutura urbana. Nos países desenvolvidos grandes quantidades de recursos têm sido gastos com infra-estrutura urbana; isto ocorre devido à necessidade de um gerenciamento da água urbana e da elevação da consciência pública da poluição causada pelo efluente urbano.

As mudanças nas regras da drenagem urbana e o desenvolvimento de tecnologia de processamento de informações têm imposto a necessidade do desenvolvimento de produtos e ferramentas para a solução dos problemas apresentados. Simulações computacionais, projetos, otimização, controle em tempo real e gerenciamento são alguns dos recursos atualmente utilizados para o desenvolvimento dos sistemas de drenagem.

Segundo Vaz Filho (2000), a Figura 6, percebe-se claramente que os sistemas de drenagem de águas superficiais possuem várias inter-relações e o bom funcionamento depende de perfeito relacionamento do mesmo com uma série de outros subsistemas. A existência de cadastro confiável das redes de água, esgoto e sistemas de drenagem, serviço de limpeza pública adequado, pavimentação das vias públicas, vontade política de buscar soluções, são alguns dos fatores fundamentais para se ter a minimização ou até mesmo a solução do problema.

\footnotetext{
"MAKSIMOVIC, C.; TODOROVIC, Z. (1998). Non-Structural vs. Structural Alternatives in Sustainable Urban Runoff Management. International Workshop on Non-Structural Flood Control in Urban Areas, São Paulo: IWRA, 1998, p.1-22 apud VICENTINI, T.A. (2000). Análise do Efeito da Urbanização nas Cheias Urbanas Monitoramento de Bacias Experimentais. p.171. Tese (Doutorado) - Universidade Estadual de Campinas (UNICAMP). Campinas, 2000.
} 


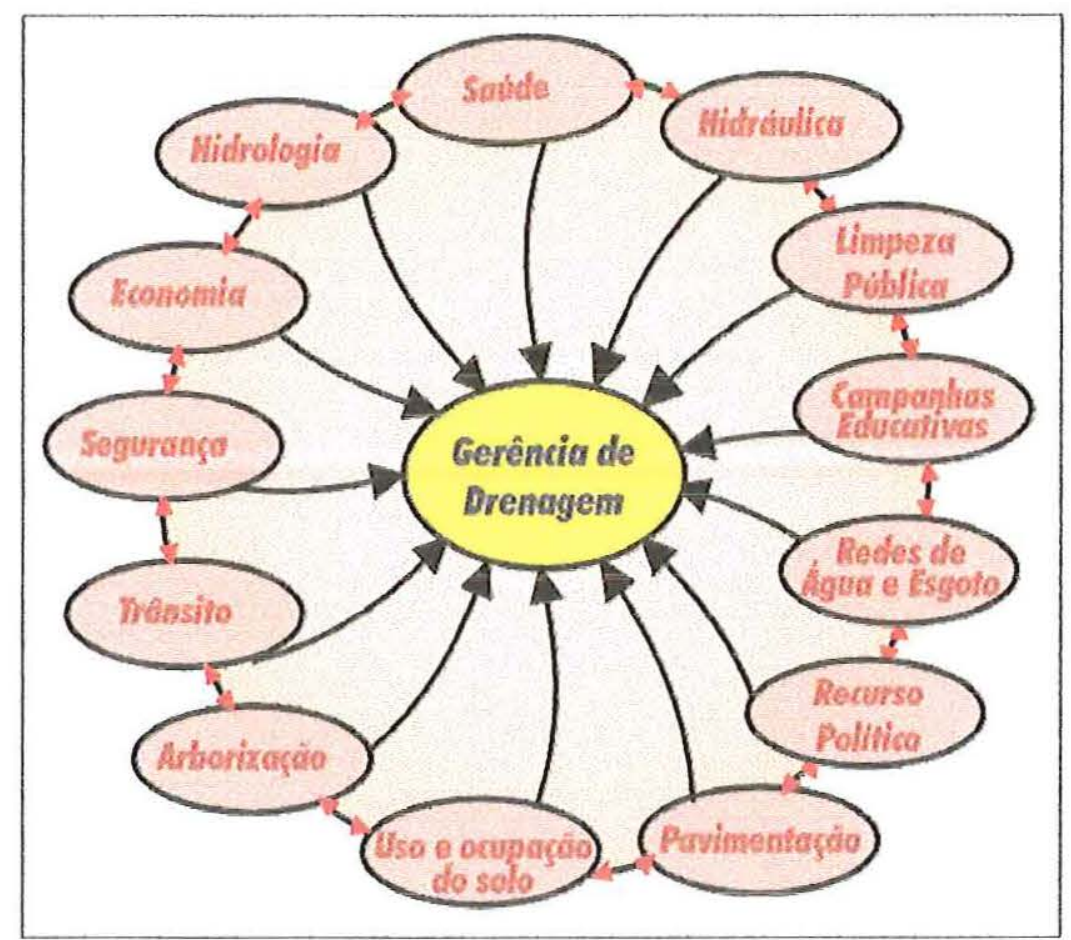

Figura 6 - O gerenciamento da drenagem e as suas inter-relações.

Fonte: Vaz Filho (2000, p.4).

Portanto, pode-se dizer que os problemas que afetam os sistemas de drenagem urbana só serão minimizados quando houver gerenciamento adequado dos mesmos, o que permitirá melhor utilização do dinheiro público e menores prejuízos.

As técnicas hidrológicas de estudo de drenagem urbana aplicam-se a bacia hidrográfica de pequeno e médio porte e, por isso, é importante dispor de algum critério de distinção entre essas bacias para poder escolher os métodos e parâmetros hidrológicos mais adequados a cada tipo de bacia.

Segundo Tucci (2001), a distinção entre esses tipos de bacia será sempre imprecisa e dependente de certo grau de subjetividade, dado a natural variação dos parâmetros que influem no comportamento hidrológico da bacia. Os critérios mais comuns, entretanto, classificam como bacia pequena aquela cuja área de drenagem seja inferior a $2,5 \mathrm{Km}^{2}$ ou o tempo de concentração seja inferior a 1 hora. Para bacias médias os limites superiores são, respectivamente, $1000 \mathrm{Km}^{2}$ e 12 horas.

Às principais conseqüências dessa classificação referem-se à escolha do método para cálculo das vazões máximas e à forma de determinar os parâmetros hidrológicos utilizados nesses métodos. Em bacias pequenas usa-se o método racional, porque as 
hipóteses deste método adequassem às características de comportamento hidrológico dessas bacias. A equação do método racional é a seguinte:

$Q=0,278 C I A$

onde Q - vazão máxima, em $\mathrm{m}^{3} / \mathrm{s} ; 0,278$ - fator para correção de unidade; C coeficiente de escoamento superficial da bacia; I - intensidade da precipitação de projeto, em $\mathrm{mm} / \mathrm{h}$; A - área da bacia, em $\mathrm{Km}^{2}$.

As bacias médias normalmente se utilizam técnicas baseadas na teoria do Hidrograma Unitário (HU), porque estas bacias permitem considerar a variação da intensidade da chuva no tempo e o amortecimento na bacia. A aplicação do método racional a bacias médias não é recomendável, porque superestima as vazões de pico.

A drenagem urbana inicia-se em edificações com os coletores pluviais ligados a rede pública, na drenagem superficial das sarjetas que recebe a parcela superficial das ruas, calçadas, pátios e outras áreas-impermeáveis ou permeáveis que geraram escoamento superficial. O escoamento proveniente das sarjetas, que entra na rede através dos bueiros, e o proveniente dos coletores residenciais são drenados pelos condutos pluviais que alimentam os condutos secundários até os principais sistemas compostos de pequenos rios (arroios, riachos ou ribeirões) que compõem a macrodrenagem urbana.

A drenagem urbana é dimensionada em dois níveis principais: microdrenagem e macrodrenagem. As estruturas de macrodrenagem destinam-se à condução final das águas captadas pela drenagem primária, dando prosseguimento ao escoamento dos deflúvios oriundos de ruas, sarjetas, valas e galerias, que são estruturas de microdrenagem. A macrodrenagem de uma zona urbana corresponde à rede de drenagem natural, pré-existente nos terrenos antes da ocupação, constituída pelos córregos, riachos e rios.

\subsubsection{Macrodrenagem}

A macrodrenagem é um conjunto de obras que visa melhorar as condições de escoamento de forma a atenuar os problemas de erosão, assoreamento e inundação ao longo dos principais talvegues. Ela é responsável pelo escoamento final das águas, a 
qual pode ser formada por canais naturais ou artificiais, galerias de grandes dimensões e estruturas auxiliares. A macrodrenagem de uma zona urbana corresponde à rede de drenagem natural pré-existente nos terrenos antes da ocupação, sendo consituída pelos igarapés, córregos, riachos e rios localizados nos talvegues e valas.

Tucci (2001), entende-se por macrodrenagem as intervenções em fundos de vale que coletam águas pluviais de áreas providas de sistemas de microdrenagem ou não. Nesses fundos de vale o escoamento é normalmente bem definido, mesmo que não exista um curso de água perene. Ela pode ser caracterizada como os escoamentos em fundos de vale que normalmente são bem definidos mesmo que não correspondam a um curso de água perene.

Os canais são cursos d'água artificiais destinados a conduzir água à superfície livre. A topografia do terreno, natureza do solo e o tipo de escoamento, determinam a forma da seção a ser adotada, as inclinações de taludes e declividade longitudinal dos canais. Apesar de independentes, as obras de macrodrenagem têm um estreito relacionamento com o sistema de drenagem urbana, portanto, devem ser projetadas conjuntamente para uma determinada área.

As obras de macrodrenagem consistem em:

- Retificação e/ou ampliação das seções de cursos naturais;

- Construção de canais artificiais oú galerias de grandes dimensões;

- Estruturas auxiliares para proteção contra erosões e assoreamento, travessias e estações de bombeamento.

As razões para a necessidade de implantar ou ampliar nos centros urbanos, as vias de macrodrenagem são:

- Saneamento de áreas alagadiças;

- A ampliação da malha viária em vales ocupados;

- Evitar o aumento de contribuição de sedimento provocado pelo desmatamento e manejo inadequado dos terrenos, lixos lançados sobre os leitos;

- A ocupação dos leitos secundários de córregos. 
Para isso, são necessárias obras de macrodrenagem que sejam eficientes e atendam a população sem causar danos sociais e econômicos. Então alguns critérios e estudos devem ser seguidos para se realizar essas obras:

- Levantamento topográfico que permita:

- Avaliar o volume da água empoçada;

- Conhecer a superfície do pântano em diferentes alturas;

o Determinar a profundidade do ponto mais baixo a drenar;

○ Encontrar a localização de uma saída apropriada;

- Determinar o traçado dos canais ou valas.

- Estudo da origem da água que alimenta a área alagada, análise das conseqüências prováveis da vazão máxima e mínima, o uso da água e a reprodução de vetores:

- Estudo do subsolo com ênfase na sua permeabilidade;

- Distâncias a zonas povoadas, de trabalho ou lazer;

- Exame das possibilidades de utilizar o material ao escavar as valas;

○ Estudo das conseqüências ecológicas e da aceitação da drenagem pela população.

As obras de macrodrenagem buscam evitar as enchentes devido à bacia urbana, isto é, construção de canais, revestidos ou não, com maior capacidade de transporte que o canal natural e bacias de detenção. As Figuras 7 e 8 representam a canalização de um trecho dos córregos do Tijuco Preto e do Gregório, afluentes da Bacia do Monjolinho, que fazem parte da rede de macrodrenagem da cidade de São Carlos.

Segundo Tucci (2001), o dimensionamento hidrológico da canalização projetada deve ser capaz de conduzir a vazão de projeto. Os critérios usualmente recomendados para a determinação das vazões de projeto são: - os cálculos hidrológicos devem considerar a ocupação futura da bacia; - o período de retorno recomendado é 100 anos.

Como as bacias passíveis de obras de macrodrenagem tendem a ser bacias de porte médio, normalmente se utilizam métodos de cálculos de cheias baseados na teoria do Hidrograma Unitário. A tendência atual é cada vez mais acentuada no sentido da utilização de modelos de simulação matemática em face das inúmeras vantagens que esses métodos apresentam (TUCCI, 2001). 


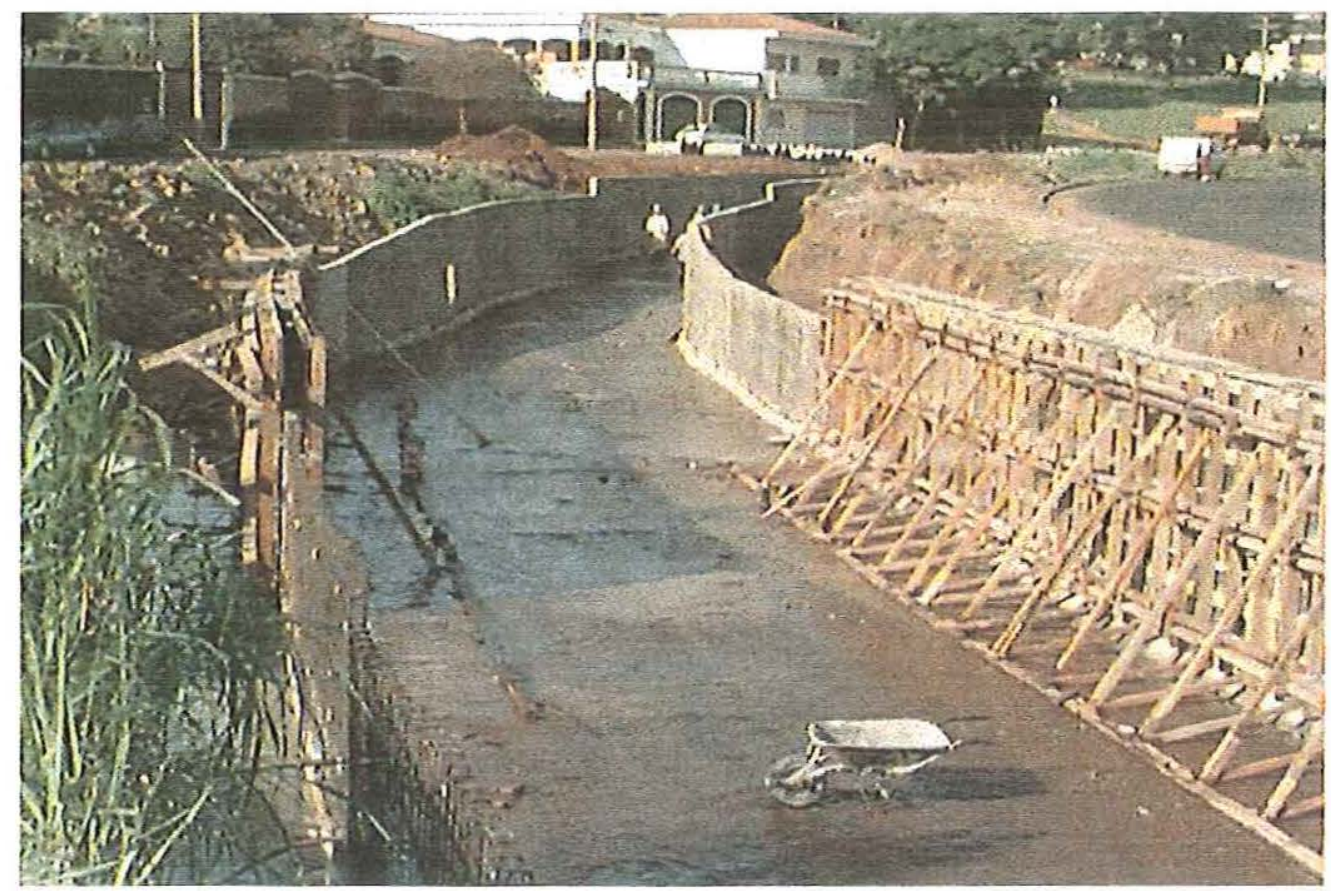

Figura 7 - Canalização de uma parte do Córrego do Tijuco Preto, na Av. Trabalhador São Carlense, em frente à USP.

Fonte: Pedro Caballero (Defesa Civil, 1999).

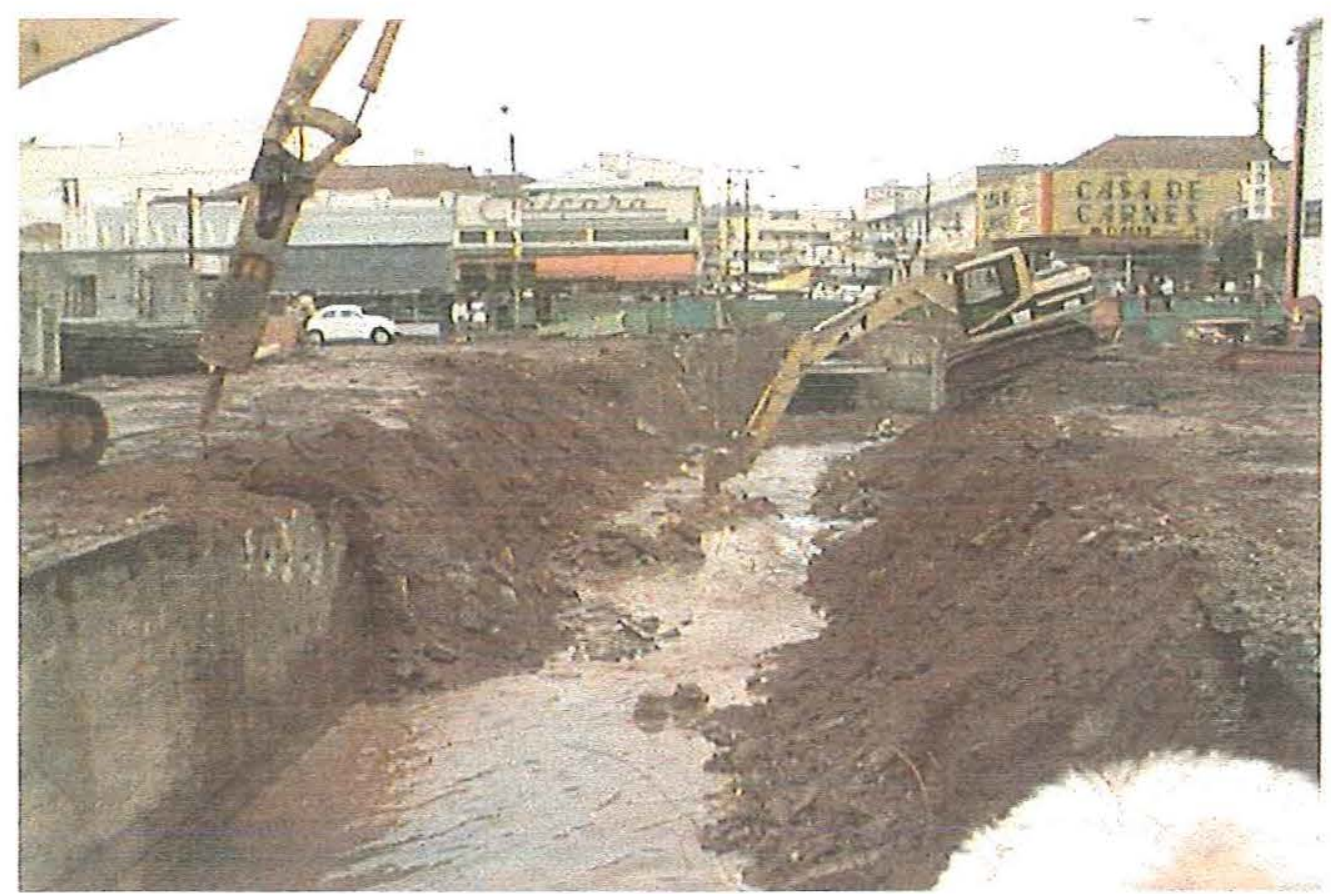

Figura 8 - Canalização de um trecho do Córrego do Gregório, ao lado do Mercado Municipal.

Fonte: Pedro Caballero (Defesa Civil, 2003). 


\subsubsection{Microdrenagem}

Segundo Vaz Filho (2000), nas cidades, as águas das chuvas após caírem nos telhados e/ou quintais das residências, escoam por estes até chegarem ao primeiro elemento do sistema de microdrenagem urbana, ou seja, as ruas. Os caudais escoam pelo conjunto guia-sarjeta-pavimento e sarjetões até serem captados pelas bocas-delobo, e destes, através de ramais de ligação, até chegarem às galerias de águas pluviais, para daí serem encaminhados até os condutos finais localizados nos fundos de vale. Além desses dispositivos, as caixas de ligação e/ou passagem, os poços de visita, os muros de ala, etc., também compõem o sistema de microdrenagem urbana.

A microdrenagem urbana é definida pelo sistema de condutos pluviais em nível de loteamento ou de rede primária urbana, que propicia a ocupação do espaço urbano ou periurbano por uma forma artificial de assentamento, adaptando-se ao sistema de circulação viária. A definição dos componentes que formam a microdrenagem é a seguinte:

- Boca de lobo: dispositivos para captação de águas pluviais, localizados nas sarjetas;

- Sarjetas: elemento de drenagem das vias públicas. A calha formada é a receptora das águas pluviais que incidem sobre as vias públicas e que para elas escoam;

- Poço de visita: dispositivos localizados em pontos convenientes do sistema de galerias para permitirem mudança de direção, mudança de declividade, mudança de diâmetro e limpeza das canalizações;

- Tubos de ligações: são canalizações destinadas a conduzir as águas pluviais captadas nas bocas de lobo para a galeria ou para os poços de visita;

- Condutos: obras destinadas à condução das águas superficiais coletadas.

\subsubsection{Plano diretor de São Carlos}

O Plano Diretor do município de São Carlos está em processo de elaboração, que se iniciou em meados do ano de 2001, através de intensas pesquisas realizadas junto às Universidades, Centros de Pesquisas, bancos de dados Estaduais e Federais, bem 
como Secretarias, Autarquias e Fundações Municipais e, com maior intensidade no ano de 2002.

Junto ao processo de elaboração do Plano Diretor da cidade também foram incorporados debates realizados em eventos abertos, tais como, o seminário sobre o Estatuto da Cidade nas Cidades Médias, que ocorreu em outubro de 2001, as atividades do Fórum da Cidade de novembro de 2001, a Conferência da Cidade realizada em 24 de agosto de 2002, entre outros.

A Conferência da Cidade foi um momento fundamental deste processo em que a administração municipal e a sociedade puderam compartilhar e debater um diagnóstico do município, com seus problemas, seus conflitos e, principalmente, suas potencialidades. A Conferência, assumindo de forma consensual a dimensão participativa do processo de elaboração do Plano Diretor, aprovou a criação de um Comitê Consultivo do Plano Diretor, com representação de entidades da sociedade civil e de uma Comissão Executiva, composta por representantes da administração municipal.

O Comitê Consultivo aprovou um cronograma de reuniões para debater e aprofundar o diagnóstico e a identificação de conflitos e potencialidades do desenvolvimento do município, segundo os temas a seguir:

- Legislação;

- Saneamento, Preservação e Recuperação Ambiental na Cidade e no Município;

- Territorialização das Atividades Econômicas;

- Processo de Desenvolvimento Urbano.

Os temas citados acima estão apresentados mais detalhadamente, no ANEXO A, através de uma estrutura desenvolvida pelo Comitê Consultivo da Prefeitura Municipal de São Carlos. Além disso, após a Conferência da Cidade, a Prefeitura Municipal de São Carlos elaborou um CD-ROM com um conjunto de informações de dados obtidos das apresentações e dos debates deste último evento. O ANEXO B contém um CDROM, com as informações obtidas desta Conferência, que foi bastante útil para este estudo. 
Seqüencialmente, a esse evento, iniciou-se o processo de escuta da sociedade através de entrevistas com representantes das principais entidades da cidade, com o objetivo de compreender como as entidades da sociedade civil e os membros do Conselho do Orçamento Participativo (OP) vêem o processo de construção do Plano Diretor da cidade.

Este processo foi realizado em agosto de 2002 por representantes do Instituto Pólis, pelo Secretário de Habitação e Desenvolvimento Urbano e pela Diretora de Desenvolvimento Urbano. Os dados fornecidos pelo Instituto Pólis também estão inseridos no CD-ROM, do ANEXO B.

Em conseqüência disso, serão definidas e discutidas as principais diretrizes para a conformação da Lei do Plano Diretor, que tem como objetivo a obtenção de um importante instrumento de política e gestão do território, em forma de lei, que deverá contemplar princípios e regras que orientarão a ação do poder público e da sociedade, nas diferentes formas de ocupação e uso do solo nas áreas urbanas e rurais do município. Ao mesmo tempo, construir coletivamente a democratização da cidade, garantir a justiça social e a inclusão social, preservando o nosso patrimônio cultural, histórico e ambiental e oferecer melhor qualidade de vida a todos os cidadãos de hoje e das próximas gerações.

\subsection{Controle de inundações urbanas}

As inundações ocasionadas pela ocupação em áreas ribeirinhas são principalmente, por um processo natural no qual a população ocupa o leito maior do rio, que de acordo com os eventos chuvosos extremos, possui em média o tempo de retorno superior à dois anos. Os rios geralmente possuem dois leitos, o leito menor onde a água escoa na maior parte do tempo e o leito maior, onde a população habita em período de estiagem ou de seqüiência de anos secos.

Os impactos sobre a população são causados, sobretudo, pela ocupação inadequada do espaço urbano. Essas condições ocorrem por não existir nenhuma restrição quanto ao loteamento de áreas de risco de inundação, em quase todas as cidades brasileiras. A razão para o loteamento destas áreas de riscos pelos empresários, é a seqüência de anos sem enchentes. Além disso, a invasão de áreas ribeirinhas, que pertencem ao poder público, pela população de baixa renda e a ocupação de áreas de 
médio risco, que são atingidas com freqüência menor, mas que quando o são, sofrem prejuízos significativos.

Os principais impactos sobre a população são os prejuízos de perdas materiais e humanas; a interrupção da atividade econômica das áreas inundadas; contaminação por doença de veiculação hídrica como leptospirose, cólera, entre outros e contaminação da água pela inundação de depósitos de material tóxico, estações de tratamentos e outros equipamentos urbanos.

Quanto à inundação devido à urbanização ocorre principalmente pela forma em que a drenagem urbana é projetada nas cidades e pela impermeabilização das superfícies que produzem aumento do escoamento superficial em detrimento do escoamento subterrâneo. O desenvolvimento urbano pode também produzir obstruções ao escoamento como aterros e pontes, drenagens inadequadas e obstruções ao escoamento junto a condutos e assoreamento.

À medida que a cidade se urbaniza, os impactos gerados são o aumento das vazões máximas devido ao aumento da capacidade de escoamento através de condutos e canais e impermeabilização das superfícies; o aumento da produção de sedimentos devido à desproteção das superfícies e a produção de resíduos sólidos e a deterioração da qualidade da água superficial e subterrânea, devido a lavagem das ruas, transporte de material sólido e as ligações clandestinas de esgoto cloacal e pluvial e contaminação de aqüíferos.

A forma desorganizada como a infra-estrutura urbana é implantada, tais como: (i) pontes e taludes de estradas que obstruem o escoamento, (ii) redução de seção do escoamento, (iii) deposição e obstrução de rios, canais e condutos de lixos e sedimentos e (iv) projetos e obras de drenagem inadequadas, também é um fator causador que leva as enchentes, devido à população, pois a cidade necessita ter uma infra-estrutura adequada para oferecer boas condições de vida a população.

O desenvolvimento urbano causa impacto no ciclo hidrológico com a retirada da cobertura vegetal, que provoca vários efeitos alterando os componentes do ciclo hidrológico. Com a urbanização, a cobertura da bacia é alterada para pavimentos impermeáveis e são introduzidos condutos para escoamento pluvial, que gera alterações no ciclo.

As alterações são redução da infiltração no solo, aumentando o escoamento superficial e por isso são construídos condutos pluviais para o escoamento superficial, que o torna mais rápido, ocorrendo redução do tempo de deslocamento. Desta forma as 
vazões máximas aumentam, antecipando seus picos no tempo; com a redução do aqüífero, tende a diminuir o nível do lençol freático por falta de alimentação e por isso reduz o escoamento subterrâneo e devido à substituição da cobertura natural ocorre uma redução da evapotranspiração.

De acordo com Tucci e Marques (2001), as medidas de controle atualmente adotadas nas áreas urbanas brasileiras quanto as áreas ribeirinhas e devido à urbanização têm sido realizado de forma equivocada com sensíveis prejuízos para a população. Portanto, eles apresentam uma proposta de controle de inundações e da drenagem urbana nas cidades brasileiras descrita a seguir:

\section{Inundações ribeirinhas}

O controle das inundações ribeirinhas depende dos efeitos produzidos em médias e grandes bacias que envolvem vários municípios. Um programa de inundação deste tipo deve ser desenvolvido com bases Estaduais e Federais baseadas no seguinte:

- Levantamento das cidades que periodicamente sofrem enchentes ribeirinhas;

- Mapeamento das áreas de inundações das cidades;

- Desenvolvimento de zoneamento de áreas de inundação, definindo os critérios de ocupação por município;

- Implementação das medidas do zoneamento dentro da legislação do Plano Diretor urbano da cidade.

Para estas ações serem executadas é preciso que entidades de fomento estaduais e federais criem um programa de incentivo através de: (i) fundo para elaboração dos estudos necessários, que por ser resultando do fundo da bacia hidrográfica; (ii) apoio dos órgãos de financiamento como Caixa Econômica a nível federal para a infraestrutura necessária ao direcionamento do desenvolvimento da cidade para as áreas seguras, tais como vias para novos bairros, pontes, etc.; (iii) bloquear qualquer financiamento de construção em áreas de risco previstas no zoneamento das cidades; (iv) prever recursos adicionais para as cidades que desenvolveram programa de zoneamento das áreas de inundação em caso de calamidade. 


\section{Drenagem urbana}

Os impactos da drenagem urbana podem ser analisados dentro de dois contextos espaciais diferentes, apresentados a seguir:

- Os impactos que extrapolam o município, ampliando as enchentes e contaminando a rede de rios para jusante, denominado de impacto da enchente $e$ poluição difusa nos rios que envolvem as cidades;

- O impacto dentro das cidades: estes impactos são disseminados dentro da cidade, que atingem a sua própria população. O controle neste caso é estabelecido através de medidas desenvolvidas dentro do município através de legislação municipal e ações estruturais específicas.

O primeiro tipo de impacto é a resultante das ações dentro da cidade, que são transferidas para o restante da bacia. Para o seu controle podem ser estabelecidos padrões a serem atingidos e geralmente são regulados por legislação ambiental e de recursos hídricos federal ou estadual.

Neste impacto, o controle é realizado a nível de comitê de bacia, que estabelece padrões a serem obtidos e recomenda o uso dos elementos básicos do Plano. O segundo tipo de impacto envolve a definição da legislação municipal, quanto a ocupação da várzea de inundação e impermeabilização do solo.

A maior parte dos problemas decorre da falta de capacidade de planejamento e de implementação de políticas adequadas do ponto de vista quantitativo como qualitativo, além disso, não basta apenas planejar é necessário desenvolver as ações adequadas para que o planejamento seja efetivamente implementado dentro da realidade. As ações da sociedade somente contrariam um planejamento adequado quando os mesmos são irreais ou a população é mal informada sobre as suas conseqüências, como acontece com a drenagem.

\subsubsection{Medidas estruturais}

Segundo Tucci e Marques (2001) as medidas estruturais são obras de engenharia implementadas para reduzir o risco das enchentes e também modificam o sistema fluvial, evitando os prejuízos decorrentes das enchentes. Essas medidas podem ser extensivas e intensivas. As medidas extensivas são as que agem na bacia, procurando 
modificar as relações entre precipitação e vazão; como a alteração da cobertura do solo, que reduz e retarda os picos de enchente e controla a erosão da bacia.

Simons et al. (1977 apud TUCCI, 2001, p.943) as medidas intensivas são aquelas que agem no rio e podem ser de três tipos: (i) aceleram o escoamento com construção de diques, que aumenta a capacidade de descarga dos rios e corte de meandros; (ii) retardam o escoamento com reservatórios e bacias de amortecimento; (iii) obras como canais de desvio, que desvia o escoamento.

As principais características das medidas estruturais estão resumidas na Tabela 4 e algumas dessas medidas são descritas a seguir:

- Controle da cobertura vegetal - a cobertura vegetal interfere no processo de precipitação-vazão, reduzindo as vazões máximas, devido ao amortecimento do escoamento, ainda reduz a erosão do solo que pode aumentar, gradualmente, o nível dos rios e agravar as inundações. O reflorestamento de bacias envolve um custo significativo, o que torna esta medida freqüentemente inviável;

- Controle da erosão do solo - o aumento da erosão implica a redução da área de escoamento dos rios e conseqüente aumento de níveis. O controle da erosão do solo pode ser realizado pelo reflorestamento, por pequenos reservatórios, pela estabilização das margens e práticas agrícolas corretas;

- Diques - são muros laterais de terra ou concreto, inclinados ou retos, construídos a uma certa distância das margens, que protegem as áreas ribeirinhas contra o extravasamento. Os efeitos de redução da largura do escoamento confinando o fluxo são o aumento do nível de água na seção para a mesma vazão, aumento da velocidade e erosão das margens e da seção e redução do tempo de viagem da onda de cheia, que agrava a situação dos outros locais a jusante. O maior risco existente na construção de um dique é a definição correta da enchente máxima provável, pois existirá sempre um risco de colapso, quando os danos serão piores se o mesmo não existisse;

- Modificação do rio - as modificações na morfologia do rio visam aumentar a vazão para um mesmo nível, reduzindo a sua freqüência de ocorrência. Isso pode

\footnotetext{
- SIMONS, D.B. et al. (1977). Flood Flows, Stages and Damages. Fort Collins: Colorado State University apud TUCCI, C.E.M. (2001). Hidrologia Ciência e Aplicação. Associação Brasileira de Recursos Hídricos (ABRH), Porto Alegre: Ed. Universidade/UFRGS, $2^{\mathrm{a}}$ ed., p.943.
} 
ser obtido pelo aumento da seção transversal ou pelo aumento da velocidade. Para aumentar a velocidade é necessário reduzir a rugosidade, tirando obstruções ao escoamento, dragando o rio, aumentando a declividade pelo corte de meandros ou aprofundando o rio;

- Reservatórios - o reservatório retém parte do volume da enchente, que reduz a vazão natural, procurando manter no rio uma vazão inferior àquela que provocava extravasamento do leito. O volume retido no período de vazões altas é escoado após a redução da vazão natural. O reservatório pode ser utilizado quando existe relevo conveniente a montante da área atingida, mas exige altos custos de conservação e desapropriações.

Tabela 4-Medidas estruturais.

\begin{tabular}{|c|c|c|c|}
\hline Medida & $\begin{array}{l}\text { Principal } \\
\text { Vantagem }\end{array}$ & $\begin{array}{c}\text { Principal } \\
\text { Desvantagem }\end{array}$ & Aplicação \\
\hline \multicolumn{4}{|l|}{ Medidas extensivas: } \\
\hline Cobertura vegetal & $\begin{array}{l}\text { Redução do pico de } \\
\text { cheia }\end{array}$ & $\begin{array}{l}\text { Impraticável para } \\
\text { grandes áreas }\end{array}$ & Pequenas bacias \\
\hline Controle de perda & Reduz assoreamento & $\begin{array}{l}\text { Impraticável para } \\
\text { grandes áreas }\end{array}$ & Pequenas bacias \\
\hline \multicolumn{4}{|l|}{ Medidas intensivas: } \\
\hline Diques & $\begin{array}{l}\text { Alto grau de } \\
\text { proteção de uma } \\
\text { área }\end{array}$ & $\begin{array}{l}\text { Danos significativos } \\
\text { caso falhe }\end{array}$ & Grandes rios \\
\hline $\begin{array}{l}\text { Melhoria do canal: } \\
\text {-Redução da } \\
\text { rugosidade por } \\
\text { desobstrução } \\
\text {-Corte de meandro }\end{array}$ & $\begin{array}{l}\text { Aumento da vazão } \\
\text { com pouco } \\
\text { investimento } \\
\text { Amplia a área } \\
\text { protegida e acelera o } \\
\text { escoamento }\end{array}$ & $\begin{array}{l}\text { Efeito localizado } \\
\text { Impacto negativo em rio } \\
\text { com fundo aluvionar }\end{array}$ & $\begin{array}{l}\text { Pequenos rios } \\
\text { Área de inundação } \\
\text { estreita }\end{array}$ \\
\hline $\begin{array}{l}\text { Reservatórios: } \\
\text {-Todos os } \\
\text { reservatórios } \\
\text {-Reservatórios com } \\
\text { comportas } \\
\text {-Reservatórios para } \\
\text { cheias }\end{array}$ & $\begin{array}{l}\text { Controle a jusante } \\
\text { Mais eficiente com } \\
\text { o mesmo volume } \\
\text { Operação com } \\
\text { mínimo de perdas }\end{array}$ & $\begin{array}{l}\text { Localização difícil } \\
\text { Vulnerabilidade a erros } \\
\text { humanos } \\
\text { Custo não partilhado }\end{array}$ & $\begin{array}{l}\text { Bacias } \\
\text { intermediárias } \\
\text { Projetos de usos } \\
\text { múltiplos } \\
\text { Restrito ao controle } \\
\text { de enchentes }\end{array}$ \\
\hline $\begin{array}{l}\text { Mudança do canal: } \\
\text {-Caminho da cheia } \\
\text {-Desvios }\end{array}$ & $\begin{array}{l}\text { Amortecimento de } \\
\text { volume } \\
\text { Reduz vazão do } \\
\text { canal principal }\end{array}$ & $\begin{array}{l}\text { Depende da topografia } \\
\text { Depende da topografia }\end{array}$ & $\begin{array}{l}\text { Grandes bacias } \\
\text { Bacias médias e } \\
\text { grandes }\end{array}$ \\
\hline
\end{tabular}

Fonte: Tucci (2001, p.628). 


\subsubsection{Medidas não-estruturais}

As medidas não-estruturais, em conjunto com as estruturais ou sem essas, podem minimizar significativamente os prejuízos causados pelas enchentes, com um custo menor. Estas medidas são aquelas em que os prejuízos são reduzidos pela melhor convivência da população com as enchentes. É ingenuidade do homem imaginar que poderá controlar totalmente as inundações; as medidas visam minimizar as suas conseqüências.

De acordo com Vicentini (2000) as medidas não-estruturais são aquelas em que se procura reduzir os danos ou conseqüências das inundações não por intervenções constituídas por obras, mas fundamentalmente pela introdução de normas, regulamentos e programas que visam, por exemplo, o disciplinamento do uso e ocupação do solo, a implantação de sistemas de alerta, a conscientização da população quanto à manutenção dos diversos componentes do sistema de drenagem.

Tucci e Marques (2001) caracterizaram as seguintes medidas não-estruturais:

- Regulamentação do uso da terra ou zoneamento de áreas inundáveis - para regulamentar é necessário estabelecer o risco de inundação das diferentes cotas das áreas ribeirinhas. Nas áreas de maior risco não é permitido a habitação e pode ser utilizada para recreação desde que o investimento seja baixo e não se danifique, como parques e campos de esportes. Para cotas com menos riscos são permitidos construções com precauções especiais. Além disso, são efetuadas recomendações quanto aos sistemas de esgoto cloacal, pluvial e viário. Esta regulamentação deve ficar contida dentro do Plano Diretor da cidade;

- Construção à prova de enchentes - é definida como o conjunto de medidas projetadas para reduzir as perdas de prédios localizados nas várzeas de inundação durante a ocorrência das cheias;

- Seguro de enchente - permite aos indivíduos ou empresas a obtenção de uma proteção econômica para as perdas eventuais;

- Previsão e alerta - é um sistema composto de aquisição de dados em tempo real, transmissão de informação para um centro de análise, previsão em tempo atual com modelo matemático, e Plano de Defesa Civil que envolve todas as ações individuais ou de comunidade para reduzir as perdas durante as enchentes. 
A combinação destas medidas permite reduzir os impactos das cheias e melhorar o planejamento da ocupação da várzea. Como o zoneamento de inundação pressupõe a ocupação com risco, torna-se necessário que exista um sistema de alerta para avisar a população sobre os riscos durante a enchente. O seguro e a proteção individual contra enchente são medidas complementares, necessárias para minimizar impactos sobre a economia da população.

\subsubsection{Controle de inundação com obras hidráulicas}

O desenvolvimento de uma bacia hidrográfica provoca o aumento de picos dos hidrogramas de cheias, em decorrência do aumento da área impermeabilizada da bacia, da redução de seu tempo de concentração, e da eliminação de armazenamentos naturais. Para contornar o problema criado com a urbanização das bacias sobre o comportamento das cheias, que causam inundações, medidas estruturais podem ser adotadas, como é o caso de obras hidráulicas.

As principais obras de controle de inundação no leito do rio são: reservatórios, diques, ampliação da seção do rio, corte de meandros e redução da rugosidade. Na avaliação do funcionamento das obras projetadas são utilizados as vazões e o hidrograma de projeto.

À medida que o centro urbano se desenvolve faz-se necessário um remodelamento do sistema de drenagem para adaptá-lo a uma nova situação com hidrogramas de cheias mais rápidos e mais críticos. Desta forma, estas medidas não são definitivas e nem sustentáveis, pois resolve o problema da cheia em uma área, mas transfere este problema para jusante.

Tucci e Marques (2001) na tentativa de se proteger contra as cheias urbanas, apresentou a idéia de reconstruir a vazão de pré-ocupação, fazendo com que a água das chuvas volte a ser interceptada, antes de atingir a rede de drenagem. Desta forma, as chamadas estruturas alternativas ou compensatórias de drenagem, como trincheiras de infiltração, pavimento permeável e microreservatórios de detenção, são apresentados como bons instrumentos de controle do escoamento superficial.

\subsection{Escoamento superficial}


Segundo Tucci (1998) o escoamento superficial é a parte do ciclo hidrológico em que a água se desloca na superfície da bacia até encontrar uma calha definida. Quando a bacia é rural e possui cobertura vegetal, o escoamento na superfície sofre interferência desta cobertura e grande parte dele se infiltra. O escoamento em bacias urbanas é regido pela interferência do homem através de superfícies impermeáveis e sistema de esgotos pluviais.

O comportamento do escoamento superficial depende essencialmente da cobertura da bacia, de sua declividade e do sistema de drenagem. A representação do escoamento em seus menores detalhes é difícil, devido à grande variabilidade das condições físicas das bacias. O escoamento é idealizado com profundidade pequena e grande largura.

Esse escoamento tem sido representado por modelos bidimensionais (longitudinal e transversal) e unidimensional. Eles limitam sérias limitações à grande variabilidade do relevo, disponibilidade de informações e aspectos numéricos de soluções das equações.

O deslocamento da água na superfície da bacia, nos rios, canais e reservatórios é uma das parcelas mais importantes do ciclo hidrológico. O escoamento é regido pelas leis físicas e representa quantitativamente variáveis como vazão, profundidade e velocidade.

O comportamento do escoamento é descrito por equações de conservação de massa, quantidade de movimento e energia. A equação baseada na conservação de massa é obtida pela avaliação das massas internas e externas que atuam no mesmo. No caso de um rio, a vazão de montante, a contribuição lateral e a vazão de saída são as entradas e saídas que devem preservar a massa do sistema, identificado como o trecho do rio.

A equação de continuidade baseada na conservação de massa fica:

$$
\frac{\partial A}{\partial t}+\frac{\partial Q}{\partial x}=q
$$

que representa a equação geral ou

$$
b \frac{\partial y}{\partial t}+\frac{\partial Q}{\partial x}=q
$$

onde $\mathrm{b}=$ largura e $\mathrm{y}=$ profundidade, caso o canal seja retangular e/ou prismático. 
A função de conservação da quantidade de movimento de um corpo é o vetor soma de todas as forças aplicadas a esse corpo num período t, e as principais forças são: gravidade, atrito e pressão. Esta equação é representada por:

$$
\frac{\partial Q}{\partial t}+\frac{\partial\left(Q^{2} / A\right)}{\partial x}+g A \frac{\partial y}{\partial x}=g A S_{0}-g A S_{f}
$$

Os dois primeiros termos são denominados de termos de inércia, o terceiro refere-se à força de pressão e os dois termos da direita da equação são os termos de gravidade e atrito.

Além disso, a energia que é definida como outra possível descrição do estado de movimento, usualmente generalizado, na presença de um campo gravitacional, o que inclui o estado vertical de deslocamento, o qual pode ser considerado como o estado da capacidade de movimento do sistema.

$\mathrm{O}$ escoamento em superfície livre pode ser permanente e não-permanente. A condição de escoamento permanente é utilizada para cálculo de remanso em rios, na análise de perfil de cheias; no escoamento em estiagem, como base para a análise qualitativa da água; e dimensionamento de obras hidráulicas. O escoamento em regime não-permanente considera a variação no tempo e no espaço das variáveis que retratam o mesmo. Esta situação ocorre na maioria dos problemas hidrológicos de escoamento superficial e de rios e canais.

\subsubsection{Modelos de escoamento superficial}

Chow* (1959 apud TUCCI, 1998, p.669) classificou os modelos de escoamento em hidrológicos e hidráulicos. No primeiro grupo estão os modelos que consideram somente o efeito do armazenamento no escoamento, desprezando a formulação dos efeitos da equação de quantidade de movimento. Os modelos hidráulicos, segundo a definição de Chow (1959), são os modelos que usam a equação de Saint Vénant.

Atualmente os modelos ditos hidrológicos são denominados do tipo armazenamento devido à predominância deste efeito na definição das equações.

\footnotetext{
' CHOW, V.T. (1959). Open Channel Hydraulics. McGraw Hill, p.680 apud TUCCI, C.E.M. (1998). Modelos Hidrológicos. Associação Brasileira de Recursos Hídricos (ABRH), Ed. Universidade/UFRGS, Porto Alegre/RS, p.669.
} 
Os modelos que utilizam a equação da continuidade e a equação quantidade de movimento, desprezando-se os termos de pressão e de inércia, são ditos modelos onda cinemática. Quando existe o efeito de jusante sobre o escoamento proveniente de montante, os modelos anteriores não podem retratar este processo, pois consideram o escoamento unidirecional (montante para jusante). Ao introduzir o termo de pressão no modelo de onda cinemática, este tipo de escoamento pode ser representado. Neste caso o modelo é dito de difusão.

Os modelos de difusão não consideram os termos de inércia. Estes termos são importantes quando ocorre grande variação temporal e espacial da velocidade do sistema. Neste caso, passa a ser importante o uso do modelo hidrodinâmico que considera a equação de quantidade de movimento completa.

Segundo Tucci (1998), a Tabela 5 apresenta um resumo das características dos modelos de escoamento.

Tabela 5 - Resumo das características dos modelos de escoamento.

\begin{tabular}{|c|c|c|c|c|c|}
\hline Modelos & Distribuído & $\begin{array}{c}\text { Efeito de } \\
\text { Jusante }\end{array}$ & $\begin{array}{c}\text { Termos de } \\
\text { Pressão }\end{array}$ & $\begin{array}{c}\text { Termos de } \\
\text { Inércia }\end{array}$ & $\begin{array}{c}\text { Dados } \\
\text { Físicos }\end{array}$ \\
\hline Armazenamento & Não & Não & Não & Não & Não \\
\hline Onda Cinemática & Sim & Não & Não & Não & Opcional \\
\hline Difusão & Sim & Sim & Sim & Não & Opcional \\
\hline Hidrodinâmico & Sim & Sim & Sim & Sim & Sim \\
\hline
\end{tabular}

Fonte: Tucci (1998, p.94).

Os modelos usualmente utilizados para representar o escoamento superficial têm sido classificados em lineares e não-lineares e, em empíricos e conceituais.

Modelos lineares e não-lineares - um modelo é matematicamente linear quando a equação diferencial do mesmo é linear. A equação diferencial seguinte

$$
A_{n} \frac{d^{n} x}{d t^{n}}+A_{n-1} \frac{d^{n-1} x}{d t^{n-1}}+\ldots+A_{1} \frac{d x}{d t}+A_{0} x=y(t)
$$

é linear quando os coeficientes $\mathrm{A}_{0}, \mathrm{~A}_{1}, \ldots . \mathrm{A}_{\mathrm{n}}$ são independentes de $\mathrm{x}$ e linear invariante 
quando os coeficientes referidos são também independentes de t. O modelo é não-linear quando pelo menos um dos coeficientes depende de x. O princípio de superposição é uma das características de modelo linear. Uma determinada entrada do sistema, y1(t) produz uma saída $\mathrm{x} 1(\mathrm{t})$ e a entrada $\mathrm{y} 2(\mathrm{t})$ produz uma saída $\mathrm{x} 2(\mathrm{t})$. O princípio de superposição é válido, se a entrada y1 $(\mathrm{t})+\mathrm{y} 2(\mathrm{t})$ produz a saída $\mathrm{x} 1(\mathrm{t})+\mathrm{x} 2(\mathrm{t})$.

Modelos empíricos e conceituais - um modelo é dito conceitual quando as funções utilizadas na sua elaboração levam em consideração os processos físicos. Os modelo empíricos (black box) utilizam-se de funções empíricas que não estão relacionadas com os fenômenos físicos, mas permitem retratar a saída do sistema em função da entrada.

A literatura menciona que os modelos de escoamento superficial podem ser:

- Linear conceitual - esses modelos podem ser do tipo armazenamento, onda cinemática, difusão e dinâmico.

- Linear empírico - quando o Hidrograma Unitário Instantâneo ou discreto tem suas ordenadas determinadas por métodos como o da inversão de matriz, série de Fourier, inversão via função de Laguerre, entre outros, o modelo é empírico.

- Não-linear conceitual - a diferença com relação aos modelos lineares é que nesse caso são utilizadas as versões não-lineares das equações. Os modelos de armazenamento e onda cinemática são os mais utilizados, nesse caso, já que a declividade da superfície da bacia em geral é alta, o que aumenta a aplicabilidade desses modelos.

\subsubsection{Componentes do hidrograma}

Uma chuva cuja distribuição no espaço e no tempo é perfeitamente definida, caindo sobre uma bacia de características físicas definidas (aspecto geomorfológico, natureza do solo, cobertura vegetal, etc.) com condições iniciais hidrológicas e climáticas determinadas, dá lugar necessariamente no local de saída da bacia de drenagem considerada a um hidrograma bem definido.

O estudo das características do hidrograma de um curso d'água é feito observando e registrando as suas variações de vazão no decorrer do tempo. Graficamente, o resultado dessa operação é o traçado do hidrograma produzido durante 
o processo de deflúvio, que retrata as características do escoamento de um curso d'água.

Wilken (1978) define que o hidrograma de um curso d'água é a representação gráfica de suas variações de vazão dispostas em ordem cronológica. A vazão é representada como ordenada de um hidrograma cartesiano em $\mathrm{m}^{3} / \mathrm{s}(1 / \mathrm{s}, 1 / \mathrm{s}$. ha, ou $\mathrm{m}^{3} / \mathrm{h} . \mathrm{m}^{2}$ ) e o tempo como abscissa em minutos frações de hora ou horas, em bacias pequenas.

No estudo dos componentes do hidrograma, consideram-se três caminhos principais para a água de chuva chegar ao curso d'água, a saber: escoamento superficial (deflúvio direto), escoamento subsuperficial (intermediário ou hipodérmico) e escoamento subterrâneo (escoamento de base).

No escoamento superficial a água caminha sobre a superfície do solo até o leito, que significa qualquer depressão ou canaleta que possa conduzir um fio de água em escoamento turbulento, durante e um pouco depois da chuva. No escoamento intermediário a água infiltra no solo e se translada junto às raízes da cobertura vegetal, até chegar ao curso d'água, movendo-se mais vagarosamente que o escoamento superficial e atingi o curso d'água um pouco mais tarde. A proporção do escoamento total que ocorre como escoamento intermediário depende da geologia da bacia de drenagem.

Outra parte da água precipitada pode se infiltrar até atingir o lençol de água subterrânea. Este acréscimo de água subterrânea pode, eventualmente, despejar no curso d'água como escoamento subterrâneo.

Essa descrição entre os três componentes do escoamento é arbitrária e, de certo modo, artificial. Na prática, é costume considerar o escoamento total dividido somente em duas partes: deflúvio direto e escoamento de base. O deflúvio direto consiste de escoamento superficial e de uma porção substancial do escoamento hipodérmico, enquanto que o escoamento de base constitui-se principalmente de escoamento subterrâneo (WILKEN, 1978).

No caso de pequenas bacias, que envolvem chuvas de curta duração e alta intensidade, o escoamento de base é pequeno em comparação com o deflúvio direto. Assim, concentra-se o estudo do hidrograma na parte que diz respeito ao deflúvio direto. Para esse fim é necessário fazer a separação dos dois componentes.

O hidrograma típico de uma bacia, após a ocorrência de uma seqüência de precipitações é apresentado na Figura 9. Após o início da chuva, existe um intervalo de tempo em que o nível começa a elevar-se, este retardo na resposta do hidrograma é 
decorrente das perdas iniciais, ou seja, a interceptação e as depressões no solo, e do deslocamento da água pela bacia.

No período de ascensão do hidrograma verifica-se a predominância do escoamento superficial, esse período correlaciona-se com a intensidade da precipitação e com grande gradiente; a região de pico do hidrograma, próximo ao valor máximo, quando o hidrograma começa a mudar de inflexão, resultado da redução da alimentação de chuvas e/ou amortecimento da bacia. Esta região termina quando o escoamento superficial acaba, resultando somente o escoamento subterrâneo; a fase de recessão do hidrograma caracteriza o fim do escoamento superficial e a predominância do escoamento subterrâneo, que é influenciado pela infiltração e percolação da água no solo.

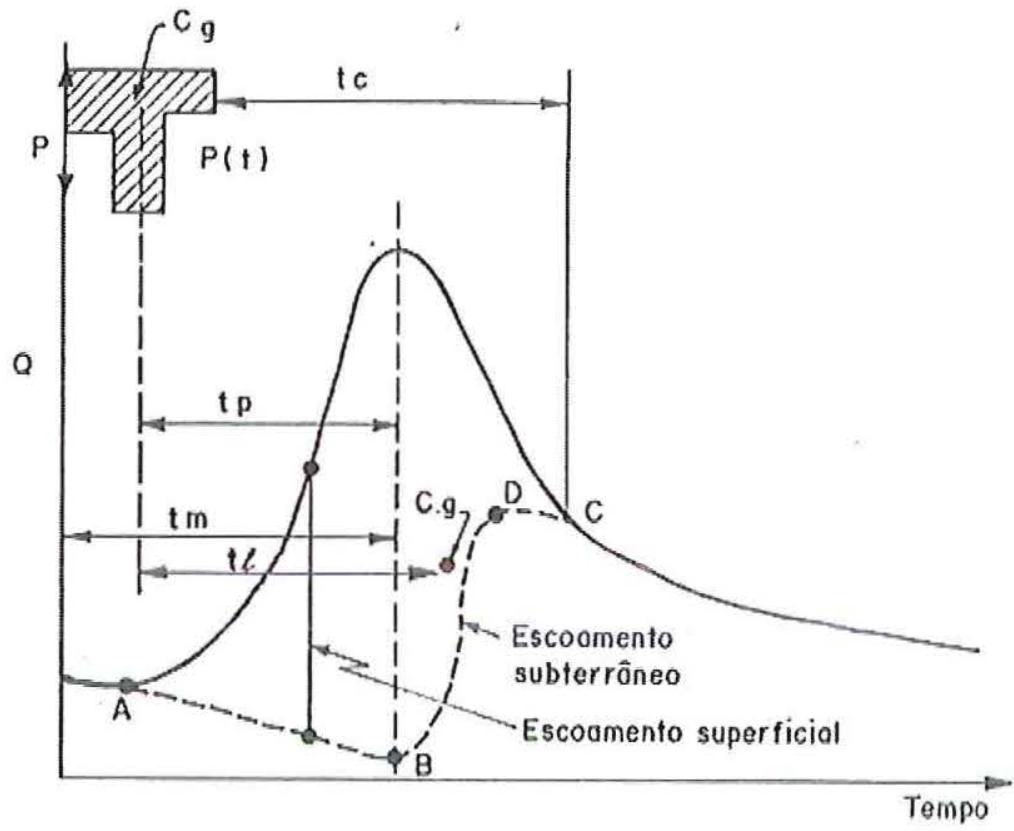

Figura 9 - Hidrograma tipo.

Fonte: Tucci (2001, p.392).

A forma do hidrograma depende de inúmeros fatores, entre eles: relevo, cobertura da bacia, modificações artificiais no rio, distribuição-duração-intensidade de precipitação e solo, entre outros.

Relevo - uma bacia com boa drenagem e grande declividade apresenta um hidrograma íngreme com pouco escoamento de base. Normalmente as cabeceiras das bacias apresentam essas características; 
Cobertura da bacia - o tipo de cobertura da bacia, como a vegetal, retarda o escoamento e aumenta as perdas por evapotranspiração. Bacias urbanas, onde a cobertura vegetal é substituída por áreas impermeáveis, o escoamento superficial e conseqüentemente o pico do hidrograma são maiores;

Modificações artificiais no rio - as modificações causadas pelo homem na calha do rio, podem contribuir para redução do pico ou seu aumento. A implantação de reservatórios para regularização da vazão tende a reduzir o pico e distribuir o volume, enquanto as canalizações tendem a produzir picos maiores e prematuros no hidrograma; Distribuição, duração e intensidade da precipitação - a distribuição da precipitação e sua duração afetam diretamente a forma do hidrograma. Quando a precipitação se encontra na maior parte inferior da bacia, deslocando-se posteriormente para montante, o hidrograma pode ter até dois picos;

Solo - as condições iniciais de umidade do solo influenciam o volume escoado superficialmente afetando diretamente o hidrograma.

Os elementos que caracterizam o hidrograma apresentado na Figura 9 e conseqüentemente o comportamento da bacia são:

- Tempo de retardo (tl) - intervalo de tempo entre o centro de massa da precipitação e o centro de gravidade do hidrograma;

- Tempo do pico (tp) - intervalo entre o centro de massa da precipitação e o tempo da vazão máxima;

- Tempo de concentração (tc) - tempo necessário para que a água precipitada no ponto mais distante da bacia se desloque até a seção de estudo, ou ainda, é o intervalo de tempo entre o fim da precipitação e o ponto de inflexão do hidrograma;

- Tempo de base (tb) - intervalo de tempo entre o início da precipitação e o tempo em que toda precipitação já escoou pela seção de estudo e o rio já voltou as condições anteriores ao início da precipitação;

- Tempo de recessão (tr) - tempo necessário para a vazão baixar até o ponto em que não existe mais o escoamento superficial. 
O escoamento superficial, que caracteriza as duas primeiras partes do hidrograma pode ser descrito por modelos, que para simular o escoamento superficial é necessário separá-lo do escoamento subterrâneo e obter a precipitação efetiva que gerou o hidrograma.

Um dos primeiros modelos apresentados para representar o escoamento superficial na bacia foi o Hidrograma Unitário. O HU é um processo de transformação de precipitação efetiva em escoamento superficial através de um método linear. A metodologia de estimativa das ordenadas do Hidrograma Unitário identifica se o modelo é conceitual ou empírico. Em conseqüência da popularidade do Hidrograma Unitário, os modelos de escoamento superficial são classificados em lineares e nãolineares e dentro desta classificação em conceituais e empíricos, como já dito no item anterior.

Segundo Porto e Righetto (1995), o Hidrograma Unitário de uma bacia é a representação da resposta dela a um estímulo chuvoso, e resulta dos diversos processos elementares de armazenamento e trânsito do escoamento superficial. Aceitando-se que o Hidrograma Unitário é uma característica invariante de cada bacia, então seus parâmetros como vazão de pico, tempo de ascensão e outros, dependem de como se processa o escoamento superficial e, portanto das características geomorfológicas da bacia.

Os Hidrogramas Unitários Sintéticos classificados como empíricos e conceituais, onde os primeiros não dependem de qualquer curva teórica a que tenham de obedecer e consideram apenas os parâmetros fundamentais que os definem, e a correlação é determinada a partir das características da bacia. Neste caso, se pode citar os hidrogramas de Snyder, regionalização de Diaz e Tucci, Triangular do Soil Conservation Service (SCS), entre outros. Já os hidrogramas conceituais devem obedecer a um certo tipo de curva, que se admite representar conceitualmente o fenômeno físico de transformação chuva-vazão. Entre eles estão os hidrogramas de Nash e Gray (PORTO e RIGHETTO, 1995).

3.6.3 Modelos para simulações de hidrogramas de cheias

\subsubsection{Modelo SCS}

Este modelo foi desenvolvido pelo Soil Conservation Service para pequenas 
bacias rurais e tem sido muito utilizado para simulações de hidrogramas de cheias de projeto de obras hidráulicas, assim como, determinar o risco de enchente para um determinado local (TUCCI, 1998).

O modelo SCS é muito utilizado em todo mundo devido ao reduzido número de parâmetros; relação entre os parâmetros e características físicas da bacia. O modelo não foi desenvolvido com o compromisso de representar um evento em específico, mas para ser utilizado para estimar o hidrograma de projeto para uma determinada bacia, que normalmente superestima. A utilização deste modelo pode ser em conjunto com um modelo de escoamento em rios e canais, para simular a propagação de diferentes subbacias, e foi preparado para simular de forma concentrada, uma bacia (TUCCI, 1998).

A estrutura do modelo apresenta os seguintes algoritmos:

- Precipitação de projeto;

- Determinação do volume superficial;

- Propagação do escoamento na bacia.

Para determinar o volume superficial o modelo utiliza a seguinte expressão:

$$
Q=\frac{\left(P-I_{a}\right)^{2}}{P+S-I_{a}}
$$

onde Q - volume superficial acumulado, em mm; P - precipitação total acumulada, em $\mathrm{mm}$; Ia - perdas iniciais; $\mathrm{S}$ - armazenamento do solo.

O método adota que as perdas iniciais representam em média $20 \%$ da capacidade de armazenamento do solo, ou seja, $I_{a}=0,2 S$, que substituindo na equação 5 , se tem:

$$
Q=\frac{(P-0,2 S)^{2}}{P+0,8 S}
$$

Esta equação é válida para $\mathrm{P}>0,2 \mathrm{~S}$ e quando $\mathrm{P}<0,2 \mathrm{~S}, \mathrm{Q}=0$ (TUCCI, 2001). Para se determinar a capacidade máxima da camada superior do solo $\mathrm{S}$, relaciona-se esse parâmetro da bacia com um fator $\mathrm{CN}$ pela expressão: 
$S=\frac{25400}{C N}-254$

onde CN está numa escala de 1 a 100, que retrata as condições de cobertura e solo, desde uma cobertura muito impermeável até uma cobertura completamente permeável, e esse fator foi tabelado para diferentes tipos de solo e cobertura (Tabelas 6 e 7).

Os tipos de solos identificados nas referidas tabelas são:

- Solo A - solos que produzem baixo escoamento superficial e alta infiltração. Solos arenosos profundos com pouco silte e argila;

- Solo B - solos menos permeáveis do que o anterior, solos arenosos menos profundo do que o tipo A e com permeabilidade superior à média;

- Solo C - solos que geram escoamento superficial acima da média e com capacidade de infiltração abaixo da média, contendo percentagem considerável de argila e pouco profundo;

- Solo D - solos contendo argilas expansivas e pouco profundos com baixa capacidade de infiltração, gerando a maior proporção de escoamento superficial. 
Tabela 6 - Valores do parâmetro $\mathrm{CN}$ para bacias rurais.

\begin{tabular}{|c|c|c|c|c|c|}
\hline Uso do Solo & Superfície & A & B & $\mathrm{C}$ & D \\
\hline \multirow{2}{*}{ Solo lavrado } & Com sulcos retilíneos & 77 & 86 & 91 & 94 \\
\hline & Em fileiras retas & 70 & 80 & 87 & 90 \\
\hline \multirow{3}{*}{ Plantações regulares } & Em curvas de nível & 67 & 77 & 83 & 87 \\
\hline & Terraceado em nível & 64 & 76 & 84 & 88 \\
\hline & Em fileiras retas & 64 & 76 & 84 & 88 \\
\hline \multirow{3}{*}{ Plantações de cereais } & Em curvas de nível & 62 & 74 & 82 & 85 \\
\hline & Terraceado em nível & 60 & 71 & 79 & 82 \\
\hline & Em fileiras retas & 62 & 75 & 83 & 87 \\
\hline \multirow{5}{*}{$\begin{array}{c}\text { Plantações de legumes } \\
\text { ou cultivados }\end{array}$} & Em curvas de nível & 60 & 72 & 81 & 84 \\
\hline & Terraceado em nível & 57 & 70 & 78 & 89 \\
\hline & Pobres & 68 & 79 & 86 & 89 \\
\hline & Normais & 49 & 69 & 79 & 94 \\
\hline & Boas & 39 & 61 & 74 & 80 \\
\hline \multirow{3}{*}{ Pastagens } & Pobres, em curvas de nível & 47 & 67 & 81 & 88 \\
\hline & Normais, em curvas de nível & 25 & 59 & 75 & 83 \\
\hline & Boas, em curvas de nível & 6 & 35 & 70 & 79 \\
\hline \multirow{4}{*}{ Campos permanentes } & Normais & 30 & 58 & 71 & 78 \\
\hline & Esparsas, de baixa transpiração & 45 & 66 & 77 & 83 \\
\hline & Normais & 36 & 60 & 73 & 79 \\
\hline & Densas, de alta transpiração & 25 & 55 & 70 & 77 \\
\hline \multirow{3}{*}{ Chácaras, estradas de terra } & Normais & 56 & 75 & 86 & 91 \\
\hline & Más & 72 & 82 & 87 & 89 \\
\hline & De superfície dura & 74 & 84 & 90 & 92 \\
\hline \multirow{4}{*}{ Florestas } & Muito esparsas, baixa transpiração & 56 & 75 & 86 & 91 \\
\hline & Esparsas & 46 & 68 & 78 & 84 \\
\hline & Densas, alta transpiração & 26 & 52 & 62 & 69 \\
\hline & Normais & 36 & 60 & 70 & 76 \\
\hline
\end{tabular}

Fonte: Tucci (2001, p.405). 
Tabela 7 - Valores de $\mathrm{CN}$ para bacias urbanas e suburbanas.

\begin{tabular}{|c|c|c|c|c|c|}
\hline \multicolumn{2}{|c|}{ Utilização ou Cobertura do Solo } & A & B & C & D \\
\hline \multicolumn{2}{|c|}{ Zonas cultivadas sem conservação do solo } & 72 & 81 & 88 & 91 \\
\hline \multicolumn{2}{|c|}{ Zonas cultivadas com conservação do solo } & 62 & 71 & 78 & 81 \\
\hline \multicolumn{2}{|c|}{ Pastagens ou terrenos em más condições } & 68 & 79 & 86 & 89 \\
\hline \multicolumn{2}{|c|}{ Baldios em boas condições } & 39 & 61 & 74 & 80 \\
\hline \multicolumn{2}{|c|}{ Prado em boas condições } & 30 & 61 & 74 & 80 \\
\hline \multicolumn{2}{|c|}{ Bosques ou zonas com cobertura ruim } & 45 & 66 & 77 & 83 \\
\hline \multicolumn{2}{|c|}{ Florestais: cobertura boa } & 25 & 55 & 70 & 77 \\
\hline \multicolumn{6}{|c|}{$\begin{array}{l}\text { Espaços abertos, relvados, parques, campos de golf, cemitérios, } \\
\text { boas condições }\end{array}$} \\
\hline \multicolumn{2}{|c|}{ com relva em mais de $75 \%$ da área } & 39 & 61 & 74 & 80 \\
\hline \multicolumn{2}{|c|}{ com relva de 50 a $75 \%$ da área } & 49 & 69 & 79 & 84 \\
\hline \multicolumn{2}{|c|}{ Zonas comerciais e de escritório } & 89 & 92 & 94 & 95 \\
\hline \multicolumn{2}{|c|}{ Zonas industriais } & 81 & 88 & 91 & 93 \\
\hline \multicolumn{6}{|c|}{ Zonas residenciais } \\
\hline \multicolumn{6}{|c|}{ Lotes de $\left(\mathrm{m}^{2}\right) \quad \%$ média impermeável } \\
\hline \multicolumn{2}{|l|}{$\leq 500$} & 77 & 85 & 90 & 92 \\
\hline \multicolumn{2}{|l|}{1000} & 61 & 75 & 83 & 87 \\
\hline \multicolumn{2}{|l|}{1300} & 57 & 72 & 81 & 86 \\
\hline \multicolumn{2}{|l|}{2000} & 54 & 70 & 80 & 85 \\
\hline \multicolumn{2}{|l|}{4000} & 51 & 68 & 79 & 84 \\
\hline \multicolumn{2}{|c|}{ Parques de estacionamentos, telhados, viadutos, etc. } & 98 & 98 & 98 & 98 \\
\hline \multicolumn{2}{|c|}{ Arruamentos e estradas } & & & & \\
\hline \multicolumn{2}{|c|}{ asfaltadas e com drenagem de águas pluviais } & 98 & 98 & 98 & 98 \\
\hline \multicolumn{2}{|c|}{ paralelepípedos } & 76 & 85 & 89 & 91 \\
\hline \multicolumn{2}{|l|}{ terra } & 72 & 82 & 87 & 89 \\
\hline
\end{tabular}

Fonte: Tucci (2001, p.406).

Os valores das constantes nas tabelas 6 e 7 referem-se às condições médias de umidade antecedente. A Tabela 8 apresenta as correções aos valores tabelados para situações diferentes da média. As condições consideradas são as seguintes: 
- AMC I - situação em que os solos estão secos. A precipitação acumulada dos cinco dias anteriores é menor que $36 \mathrm{~mm}$, na estação de crescimento e $13 \mathrm{~mm}$ em outro período;

- AMC II - situação média em que os solos correspondem à umidade da capacidade de campo;

- AMC III - situação em que ocorreram precipitações consideráveis nos cinco dias anteriores e o solo encontra-se saturado. No período de crescimento, as precipitações acumuladas nos cinco dias anteriores, são maiores que $53 \mathrm{~mm}$ e no outro maior que $28 \mathrm{~mm}$.

Tabela 8 - Correção de CN para outras condições iniciais de umidade.

\begin{tabular}{|c|c|c|}
\hline Valores médios & $\begin{array}{l}\text { Valores Corrigidos } \\
\text { (AMC I) }\end{array}$ & $\begin{array}{c}\text { Valores Corrigidos } \\
\text { (AMC III) }\end{array}$ \\
\hline 100 & 100 & 100 \\
\hline 95 & 87 & 98 \\
\hline 90 & 78 & 96 \\
\hline 85 & 70 & 94 \\
\hline 80 & 63 & 91 \\
\hline 75 & 57 & 88 \\
\hline 70 & 51 & 85 \\
\hline 65 & 45 & 82 \\
\hline 60 & 40 & 78 \\
\hline 55 & 35 & 74 \\
\hline 50 & 31 & 70 \\
\hline 45 & 26 & 65 \\
\hline 40 & 22 & 60 \\
\hline 35 & 18 & 55 \\
\hline 30 & 15 & 50 \\
\hline 25 & 12 & 43 \\
\hline 20 & 9 & 37 \\
\hline 15 & 6 & 30 \\
\hline 10 & 4 & 22 \\
\hline 5 & 2 & 13 \\
\hline
\end{tabular}

Fonte: Tucci (2001, p.408). 
A propagação superficial é realizada através do volume gerado pela separação do escoamento, que é propagado até o rio por meio do HU. O modelo utiliza o Hidrograma Unitário Sintético Triangular (HUST), obtido com base no valor do pico q, e tempo de pico $t_{p}$.

\subsubsection{Modelo de regionalização de Diaz e Tucci}

Diaz e Tucci (1989), publica o relato de um estudo com dados de dezenove bacias urbanas e suburbanas brasileiras, através do hidrograma de projeto para um certo período de retorno, pois uma das dificuldades no estudo de bacias urbanas é a determinação desse hidrograma, devido à falta de dados históricos. Eles utilizaram a técnica do Hidrograma Unitário para bacias urbanas, visando uma melhor estimativa, com características de ocupação de cidades brasileiras, que estabeleceram a regionalização dos parâmetros que caracterizam o HU.

Com os dados das dezenove bacias, estabeleceram regressões dos parâmetros que definem a forma do HU, com algumas características físicas das bacias.

A metodologia de regionalização do HU consiste nas seguintes etapas:

- Seleção dos eventos;

- Separação dos escoamentos;

- Determinação do HU para cada evento;

- Determinação do Hidrograma Unitário médio;

- Regionalização dos Hidrogramas Unitários médios.

As variáveis selecionadas para a correlação foram: vazão de pico do Hidrograma Unitário em $\mathrm{m}^{3} / \mathrm{s}(\mathrm{Qp})$, tempo de pico em minutos (tp), tempo de base em minutos (tb), largura do hidrograma a $50 \%$ do pico em minutos $\left(\mathrm{L}_{50}\right)$, largura do hidrograma a $25 \%$ do pico em minutos $\left(\mathrm{L}_{25}\right)$, área da bacia em $\mathrm{Km}^{2}$, perímetro da bacia em $\mathrm{Km}$, comprimento do talvegue do curso principal, porcentagem da área impermeável e comprimento do talvegue principal até o centro de gravidade da bacia em $\mathrm{Km}$.

Visando encontrar as melhores relações entre as características físicas das bacias e os parâmetros do Hidrograma Unitário, foram analisados quatro grupos de dados segundo a Tabela 9. 
Tabela 9 - Grupos analisados.

\begin{tabular}{|c|c|c|}
\hline Número do Grupo & Número de Bacias & Características \\
\hline I & 19 & Todas as bacias \\
\hline II & 15 & Área impermeável $>10 \%$ \\
\hline III & 15 & Área da bacia $<30 \mathrm{~km}^{2}$ \\
\hline IV & 12 & $\begin{array}{c}\text { Área impermeável }>10 \% \mathrm{e} \\
\text { Área da bacia }<30 \mathrm{~km}^{2}\end{array}$ \\
\hline
\end{tabular}

Fonte: Diaz e Tucci (1989, p.23).

Na Tabela 10 são apresentadas as equações de correlação dos quatro grupos para as referidas variáveis, com os parâmetros que identificam a qualidade do ajuste, o coeficiente de determinação $(\mathrm{R})$ e o erro padrão fatorial $(\mathrm{F})$, que quanto menor o valor deste parâmetro, melhor é o resultado. 
Tabela 10 - Equações dos diferentes grupos.

\begin{tabular}{|c|c|c|c|}
\hline \multicolumn{4}{|c|}{$Q_{p}-$ Vazão de pico $\left(\mathrm{m}^{3} / \mathrm{s}\right)$} \\
\hline Grupo & $\mathbf{R}^{2}$ & $\mathbf{F}$ & Equações \\
\hline I & 0,90 & 1,48 & $\mathrm{Q}_{\mathrm{p}}=0,07 \mathrm{ARE}^{0,44} \mathrm{TAL}^{0,78} \mathrm{DEC}^{0,19} \mathrm{I}^{0,39}$ \\
\hline II & 0,90 & 1,37 & $\mathrm{Q}_{\mathrm{p}}=0,06 \mathrm{ARE}^{0,63} \mathrm{I}^{0,66}$ \\
\hline III & 0,88 & 1,39 & $\mathrm{Q}_{\mathrm{p}}=0,24 \mathrm{ARE}^{0,16} \mathrm{I}^{0,40} \mathrm{LCG}^{0,60}$ \\
\hline IV & 0,88 & 1,36 & $\mathrm{Q}_{\mathrm{p}}=0,09 \mathrm{ARE}^{0,25} \mathrm{I}^{0,70} \mathrm{LCG}^{0,47}$ \\
\hline \multicolumn{4}{|c|}{$t_{p}-$ Tempo de pico (minutos) } \\
\hline Grupo & $\mathrm{R}^{2}$ & $\mathbf{F}$ & Equações \\
\hline I & 0,86 & 1,41 & $\mathrm{t}_{\mathrm{p}}=7,82 \mathrm{Q}_{\mathrm{p}}^{-1} \mathrm{ARE}^{1,22}$ \\
\hline II & 0,82 & 1,46 & $\mathrm{t}_{\mathrm{p}}=8,03 \mathrm{Q}_{\mathrm{p}}^{-0,95} \mathrm{ARE}^{1,17}$ \\
\hline III & 0,90 & 1,31 & $t_{p}=7,65 Q_{p}^{-1,11} A E^{0,83}$ \\
\hline IV & 0,82 & 1,36 & $t_{p}=10,57 Q_{p}^{-0,99} A R E^{1,05}$ \\
\hline \multicolumn{4}{|c|}{$\mathrm{L}_{25}$ - Largura ao $25 \%$ da vazão de pico (minutos) } \\
\hline Grupo & $\mathbf{R}^{2}$ & $\mathbf{F}$ & Equações \\
\hline I & 0,96 & 1,15 & $\mathrm{~L}_{25}=25,6 \mathrm{Q}_{\mathrm{p}}^{-0,8+} \mathrm{ARE}^{0,89} \mathrm{DEC}^{-0,08}$ \\
\hline II & 0,96 & 1,14 & $\mathrm{~L}_{25}=25,7 \mathrm{Q}_{\mathrm{p}}^{-0,93} \mathrm{ARE}^{0,88} \mathrm{DEC}^{-0,12}$ \\
\hline III & 0,96 & 1,16 & $\mathrm{~L}_{25}=25,7 \mathrm{Q}_{\mathrm{p}}^{-0,93} \mathrm{ARE}^{0,88} \mathrm{DEC}^{-0,09}$ \\
\hline IV & 0,96 & 1,15 & $\mathrm{~L}_{25}=25,7 \mathrm{Q}_{\mathrm{p}}^{-0,93} \mathrm{ARE}^{0,68}$ \\
\hline \multicolumn{4}{|c|}{$\mathrm{L}_{50}$ - Largura ao $50 \%$ da vazão de pico (minutos) } \\
\hline Grupo & $\mathbf{R}^{2}$ & $\mathbf{F}$ & Equações \\
\hline I & 0,91 & 1,21 & $\mathrm{~L}_{50}=14,8 \mathrm{Q}_{\mathrm{p}}^{-0,84} \mathrm{ARE}^{0,89}$ \\
\hline II & 0,89 & 1,20 & $\mathrm{~L}_{50}=15,3 \mathrm{Q}_{\mathrm{p}}^{-0,69} \mathrm{ARE}^{0,78}$ \\
\hline III & 0,94 & 1,17 & $\mathrm{~L}_{50}=16,8 \mathrm{Q}_{\mathrm{p}}^{-0,63} \mathrm{ARE}^{0,82}$ \\
\hline IV & 0,93 & 1,12 & $\mathrm{~L}_{50}=17,9 \mathrm{Q}_{\mathrm{p}}^{-0,63} \mathrm{ARE}^{0,68}$ \\
\hline
\end{tabular}

AREA - área da bacia, em $\mathrm{Km}^{2}$; TAL - comprimento do talvegue, em Km; DEC declividade, em \%; I - percentagem de áreas impermeáveis; LCG - comprimento do talvegue principal até o centro de gravidade da bacia, em $\mathrm{Km}^{2}$.

Fonte: Diaz e Tucci (1989, p.24). 


\subsubsection{Método de Snyder}

Segundo Snyder ${ }^{*}$ (1938 apud TUCCI, 2001, p.943), foi um dos primeiros a estabelecer um Hidrograma Unitário Sintético (HUS) com dados da região dos Montes Apalaches nos Estados Unidos da América.

O método consiste na determinação dos seguintes fatores:

\section{Tempo de pico $\left(t_{p}\right)$}

Definido como o intervalo de tempo compreendido entre o instante correspondente ao centro de gravidade do hietograma da precipitação efetiva e o pico do hidrograma. Snyder propôs a seguinte expressão para $t_{\mathrm{p}}$ :

$t_{p} 1=C_{t}\left(L . L_{c g}\right)^{p, 3}$

onde $\mathrm{t}_{\mathrm{p}} 1$ - tempo de pico 1 , em horas; $\mathrm{L}$ - comprimento do rio principal, em Km; $\mathrm{L}_{\mathrm{eg}}$ - é a distância da seção principal ao ponto do rio mais próximo ao centro de gravidade da bacia, em Km; $\mathrm{C}_{\mathrm{t}}$ - coeficiente que varia entre 1,35 a 1,65 (TUCCI, 2001).

\section{Tempo de duração da precipitação $\left(t_{d}\right)$}

Segundo Tucci (2001), o tempo de duração da precipitação é calculado por:

$$
t_{d} 1=\frac{t_{p} 1}{5,5}
$$

onde $t_{d} 1$ - tempo de duração da precipitação 1 , em horas; $t_{p} 1$ - tempo de pico 1 , em horas.

Quando se corrigi o tempo de duração da precipitação para $t_{r}$, retifica-se $t_{p}$ por:

\footnotetext{
' SNYDER, F.F. (1983). Synthetic Unit Graphs. Transactions American Geophysical Union, Washington, v.19, p.447-454 apud TUCCI, C.E.M. (2001). Hidrologia Ciência e Aplicação. Associação Brasileira de Recursos Hídricos (ABRH), Porto Alegre: Ed. Universidade/UFRGS, $2^{\text {a }}$ ed., p.943.
} 
$t_{p}=t_{p} 1+\left(t_{r}-t_{r} 1\right) / 4$

Vazão de pico $\left(\mathrm{q}_{\mathrm{p}}\right)$

A vazão de pico para uma precipitação de duração $t_{r}$ e volume de $1 \mathrm{~cm}$ fica:

$q_{p}=\frac{2,75 C_{p} A}{t_{p}}$

onde $\mathrm{q}_{\mathrm{p}}$ - vazão de pico, em $\mathrm{m}^{3} / \mathrm{s} ; \mathrm{A}$ - área de drenagem, em $\mathrm{Km}^{2} ; \mathrm{C}_{\mathrm{p}}$ - coeficiente que varia entre 0,56 e 0,69 (TUCCI, 2001).

Tempo de base $\left(t_{b}\right)$

O tempo de base do Hidrograma Unitário é estimado por:

$t_{b}=3+t_{p} / 8$

onde $t_{b}$ - tempo de base, em dias; $t_{p}$ - tempo de pico, em dias.

De acordo com Sokolov et al. ${ }^{*}$ (1975 apud TUCCI, 2001, p.943), a Figura 10 representa o Hidrograma Unitário de Snyder, que é esboçado com base em $\mathrm{q}_{\mathrm{p}}, \mathrm{t}_{\mathrm{p}}$ e $\mathrm{t}_{\mathrm{b}}$. Para se facilitar esse trabalho existem curvas para as larguras $75 \%$ e $50 \%$ do pico, obtidas com base em dados de várias bacias dos Estados Unidos.

Estas relações na forma de equações são:

$W_{75}=\frac{3,352}{\left(q_{p} / A\right)^{1,08}}$

' SOKOLOV, A.A.; RANTZ, S.E.; ROCHE, M. (1975). Floodflow Computation. Paris: UNESCO, p.194 apud TUCCI, C.E.M. (2001). Hidrologia Ciência e Aplicação. Associação Brasileira de Recursos Hídricos (ABRH), Porto Alegre: Ed. Universidade/UFRGS, $2^{\mathrm{a}}$ ed., p.943. 
$W_{50}=\frac{5,87}{\left(q_{p} / A\right)^{1,08}}$

onde $\mathrm{q}_{\mathrm{p}}$ - vazão de pico, em $\mathrm{m}^{3} / \mathrm{s} ; \mathrm{A}$ - área de drenagem, em $\mathrm{Km}^{2} ; \mathrm{W}_{75}$ e $\mathrm{W}_{50}$, em horas.

Deve-se ter cuidado ao usar estas relações, pois elas representam condições médias de um grande número de bacias americanas, o que não atende necessariamente a uma bacia em específico.

Linsley e Franzini (1978) mostraram que poderia ser empregado em outras regiões, através da modificação de constantes nas equações estabelecidas por Snyder.

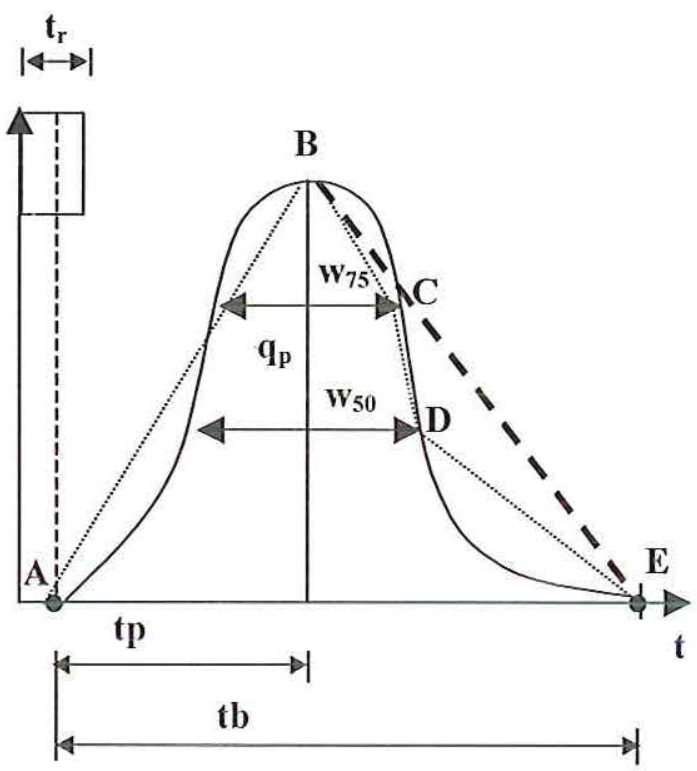

Figura 10 - HUS de Snyder.

Fonte: Tucci (2001, p.432).

\subsubsection{Método de Nash}

Segundo Righetto (1988), a fim de se conseguir um melhor ajuste entre os resultados do modelo conceitual e os obtidos de eventos observados, admite-se que a bacia possa ser representada por "n" reservatório lineares e em série, de forma que o modelo conceitual passa a ter dois parâmetro: $\mathrm{K}$ e $\mathrm{n}$. 
Nash $^{*}$ (1975 apud TUCCI, 1998, p.669) representou o escoamento superficial por $\mathrm{n}$ reservatórios em cascata. Os reservatórios têm comportamento linear com o mesmo parâmetro K, como está apresentado na Figura 11.

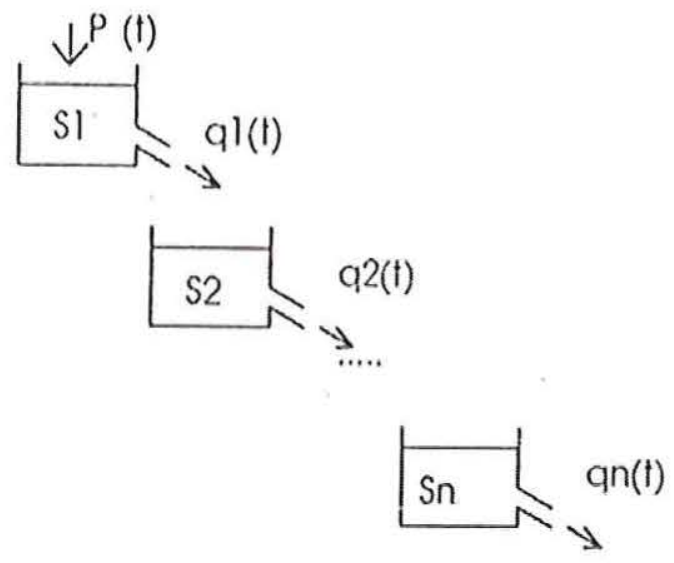

Figura 11 - Modelo Nash - Cascata em reservatórios.

Fonte: Tucci (1998, p.114).

Considerando uma precipitação unitária instantânea ocorrendo no primeiro reservatório, a saída é obtida pela seguinte equação:

$u(t)=\frac{d q}{d t}=\frac{1}{K} e^{-t / K}$

que é a equação do Hidrograma Unitário Instantâneo (HUI) para modelo de reservatório linear simples. $\mathrm{O}$ parâmetro $\mathrm{K}$ tem unidades de tempo e representa o tempo médio de esvaziamento do reservatório (TUCCI, 1998).

A entrada do segundo reservatório é o HUI do primeiro e a saída deste é obtida pela convolução do seguinte. Portanto, para dois reservatórios o HUI fica:

\footnotetext{
" NASH, J.E. (1975). The Form of the Instantaneos Unit Hydrograph. IAHS Assemblee Generale de Toronto, tome III, p.114-121 apud TUCCI, C.E.M. (1998). Modelos hidrológicos. Associação Brasileira de Recursos Hídricos (ABRH), Ed. Universidade/UFRGS, Porto Alegre/RS, p.669.
} 
$u(t)=\int_{0}^{T} \frac{1}{K} e^{-\tau / K} \frac{1}{K} e^{-(t-\tau) / K} d \tau=\frac{1}{K} \frac{t}{K} e^{-t / K}$

Para n reservatório o HUI do modelo fica:

$u(t)=\frac{1}{K}\left(\frac{1}{K}\right)^{n-1} \frac{e^{-t / K}}{(n-1) !}$

Como esta equação pode ser usada matematicamente, com $\mathrm{n}$ e $\mathrm{K}$ como parâmetros, independentemente de seu significado, foi utilizada uma Função Gama para cálculo do fatorial de um número não-inteiro, devido a isso a equação 3.18 resultou em:

$u(t)=\frac{1}{K \Gamma(n)} e^{-t / K}\left(\frac{t}{K}\right)^{n-1}$

que representa o Hidrograma Unitário Instantâneo do método de Nash.

\subsubsection{Método de Gray}

O método de Gray é baseado na função densidade de probabilidade Gama Imcompleta, e foi desenvolvido para bacias rurais do meio oeste americano, com áreas até aproximadamente $84,5 \mathrm{Km}^{2}$. Este método permite determinar as ordenadas do Hidrograma Unitário para valores de tempos a intervalos de $0,25 \mathrm{Pr}$, onde $\operatorname{Pr}$ é o tempo de ascensão do hidrograma, gerado por uma precipitação efetiva, uniforme, de duração 0,25Pr (VIESSMAN JUNIOR et al., 1977).

A aproximação do "diagrama adimensional" de Gray pode ser representada pela aproximação da expressão:

$Q t / \operatorname{Pr}=\frac{25\left(\gamma^{\prime}\right)^{q}}{\Gamma(q)}\left(e^{-\gamma^{\prime} t / \operatorname{Pr}}\right)\left(\frac{t}{\operatorname{Pr}}\right)^{q-1}$

onde, Qt/Pr - ordenada do hidrograma adimensional no instante $t / \operatorname{Pr} ; t / \operatorname{Pr}$ toma valores 0,125, 0,375, 0,626, etc.; $\mathrm{t}$ - tempo, em minutos; Pr - tempo de ascensão, em minutos; $\mathrm{q}$ 
- parâmetro de forma da distribuição Gama; $\gamma^{\prime}$ - parâmetro de escala da distribuição Gama; $\Gamma(\mathrm{q})$ - função gama de $\mathrm{q}$; e - base dos logaritmos naturais.

Para se obter o pico relativo a um valor $\mathrm{t} / \mathrm{Pr}=1$, utiliza-se a seguinte relação entre parâmetros:

$q=1+\gamma^{\prime}$

O fator de armazenamento, $\operatorname{Pr} / \gamma^{\prime}$, deve ser avaliado a partir da característica da bacia $L / \sqrt{I}$, por meio da expressão obtida por regressão:

$$
\frac{\operatorname{Pr}}{\gamma^{\prime}}=a\left(\frac{L}{\sqrt{I}}\right)^{b}
$$

onde a e b - parâmetros regionais, obtidos experimentalmente; $\mathrm{L}$ - comprimento, em $\mathrm{Km}$; I - declividade do curso d'água principal, em \%.

Há uma relação entre $\operatorname{Pr}$ e $\gamma^{\prime}$, que é dada pela equação:

$$
\frac{\operatorname{Pr}}{\gamma^{\prime}}=\frac{1}{\frac{2,676}{\operatorname{Pr}}-0,0319}
$$

As ordenadas do HUS do método de Gray são obtidas ao empregar a equação 3.20 que calcula o termo " $\%$ de escoamento/0,25Pr" a cada incremento sucessivo de $t / \mathrm{Pr}$ $=0,25$, até que o somatório das ordenadas se aproxime de $100 \%$. A partir disso, converte-se as ordenadas do diagrama adimensional nessas ordenadas, e deve-se observar que os volumes são iguais.

\subsection{Modelos hidrológicos}

A hidrologia trata dos fenômenos naturais complexos encontrados no ciclo 
hidrológico. Os processos, como a precipitação, evaporação, infiltração e o escoamento em rios, dependem de um grande número de fatores, que dificultam a análise quantitativa e qualitativa dos mesmos.

Segundo Tucci (1998), o modelo é a representação de algum objetivo ou sistema, numa linguagem ou forma de fácil acesso e uso, com o objetivo de entendê-lo e buscar suas respostas para diferentes entradas.

Dooge $^{*}$ (1973 apud TUCCI, 1998, p.669) definiu um sistema como qualquer estrutura, esquema ou procedimento, real ou abstrato, que num dado tempo de referência interrelacionam-se com uma entrada, causa ou estímulo de energia ou informação, e uma saída, efeito ou resposta de energia ou informação.

Quanto mais complexos os sistemas, mais desafiadores e necessários são os modelos. Um sistema, como a bacia hidrográfica, não foi dimensionado, mas é resultado de processos naturais. O homem deve procurar adaptar-se aos seus condicionantes, buscando entender o comportamento da bacia, para poder utilizar seus recursos, protegendo suas diferentes características. Os sistemas naturais têm a necessidade de monitorar o seu comportamento, para que seja possível prever a sua resposta a diferentes ações como precipitações extremas, modificações do uso do solo, estiagens, entre outras.

O modelo hidrológico é uma das ferramentas que a ciência desenvolveu, para melhor entender e representar o comportamento da bacia hidrográfica e prever condições diferentes das observadas. A simulação hidrológica é limitada pela heterogeneidade física da bacia e dos processos envolvidos, o que tem propiciado o desenvolvimento de um grande número de modelos que se diferenciam em função dos dados utilizados, discretização, das prioridades da representação dos processos e dos objetivos a serem alcançados.

Tucci (1998) definiu simulação como o processo de utilização do modelo e na simulação existe, em geral, três fases que são classificadas como estimativa ou ajuste, verificação e previsão. A estimativa dos parâmetros é a fase da simulação onde os parâmetros devem ser determinados. A verificação é a simulação do modelo com os parâmetros estimados onde se verifica a validade do ajuste realizado, e a previsão é a simulação do sistema pelo modelo com parâmetros ajustados para quantificação de suas respostas a diferentes entradas.

\footnotetext{
* DOOGE, J.C.I. (1973). Linear Theory of Hydrologic Systems. Technical Bulletin n. 1948, ARS, UD Department of Agriculture apud TUCCI, C.E.M. (1998). Modelos hidrológicos. Alegre/RS, p.669.
} 
Segundo Sadoun (2000) relata as etapas necessárias para o desenvolvimento de um processo de simulação, cujo qual para se simular um sistema é preciso observar a sua operação, formular hipóteses de acordo com o seu comportamento, prever o comportamento futuro do sistema baseado em suposições e hipóteses, e comparar o comportamento previsto com o comportamento real.

Maia (2002) apresenta através da Figura 12 a metodologia da simulação proposta por Sadoun (2000), que consiste em quatro etapas principais: pré-modelagem ou etapa de planejamento, etapa de modelagem, etapa de validação e verificação e etapa de experimentação e aplicação.

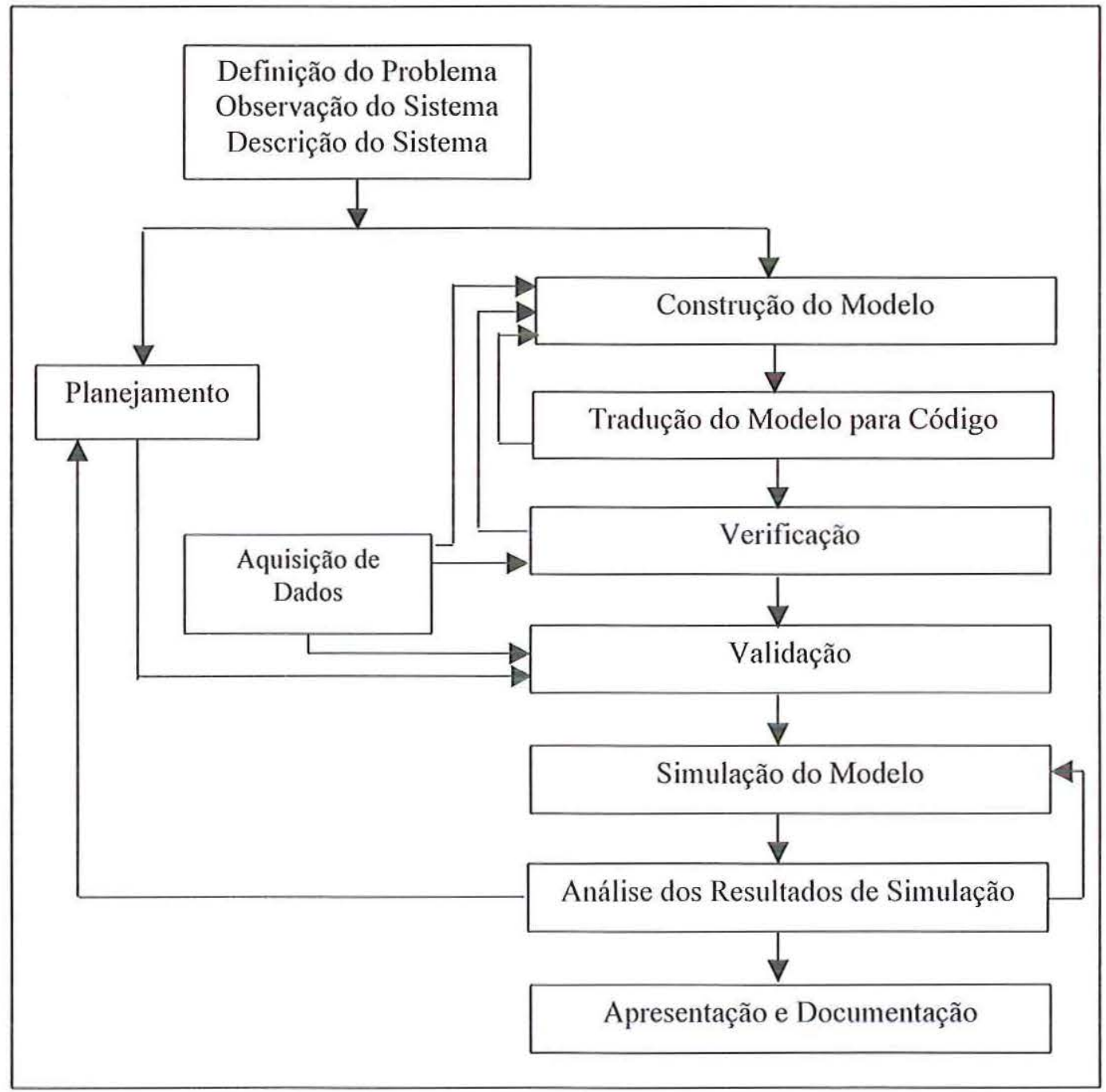

Figura 12 - Metodologia de um processo de simulação.

Fonte: Maia (2002, p.18). 
De acordo com Tucci (1998), a estimativa dos parâmetros depende da disponibilidade de dados históricos, medições de amostras e determinação das características físicas do sistema. Os métodos em geral utilizados para a estimativa dos parâmetros são:

- Estimativa sem dados históricos - quando não existem dados sobre as variáveis do sistema, pode-se estimar os valores dos parâmetros baseando-se em informações das características físicas do sistema. Em geral, cada parâmetro possui um intervalo de variação possível, obtido da literatura;

- Ajuste por tentativas - é o processo em que existindo valores das variáveis de entrada e saída, são obtidos por tentativas os parâmetros que melhor representem os valores observados e calculados pelo método;

- Amostragem - os valores dos parâmetros são obtidos através de medições específicas no sistema. Por exemplo, a estimativa da rugosidade de um canal e a área de uma bacia hidrográfica.

A verificação é a fase da simulação em que o modelo, calibrado anteriormente, é verificado com outros dados. No ajuste, os dados registrados da saída são utilizados para determinar os parâmetros. Na verificação, os dados de saída são utilizados somente para observar se o modelo, com os parâmetros anteriormente ajustados, simula o sistema adequadamente. A verificação deve ser realizada principalmente para a faixa de valores de saída que o modelo utilizará durante a previsão. Quando os parâmetros sofrem modificações com o tempo, o ajuste e a verificação devem contemplar estas condições. Uma bacia urbana que modifique as suas condições de impermeabilização e canalização terá seus parâmetros alterados.

A previsão é a fase da simulação onde o modelo, depois de ajustado e verificado, é utilizado para representar a saída do sistema para situações desconhecidas. A extensão de séries hidrológicas e a simulação de alternativas de projeto são algumas das situações freqüentemente encontradas na prática.

A utilização do modelo é necessária para se antecipar aos eventos, representando: o impacto da urbanização de uma bacia antes que ela ocorra, para que medidas preventivas possam ser tomadas; a previsão de uma enchente em tempo real; o impacto da alteração de um rio; a ocorrência de eventos extremos estatisticamente possíveis. 
Porto e Azevedo ${ }^{*}$ (1997 apud MAIA, 2002, p.143) listam algumas das características que um modelo deve ter como:

- Precisão - deve representar a realidade de forma suficientemente próxima;

- Simplicidade - um número reduzido de parâmetros e variáveis, além de uma estrutura que represente somente a essência do sistema;

- Robustez - representar bem a realidade com o menor número possível de parâmetros;

- Transparência - total entendimento do modelo por parte de quem o opera;

- Adequação - interação com o usuário de forma clara, simples e inequívoca.

De acordo com Tucci (1998), os modelos são construídos segundo algumas considerações e simplificações, a depender destas características, e do seu objetivo para os quais foram construídos, eles podem ser classificados como:

- Memória - é a dependência dos dados de saída com os dados de entrada do sistema, em função do tempo. No caso de memória zero a entrada afeta o sistema somente no período em que é aplicada;

- Linearidade - um sistema é linear quando é validado o princípio de superposição. A propriedade de superposição existe quando a resposta a um evento y1 e y2 ocorridos ao mesmo tempo é a mesma do evento y1 e do evento y2 ocorridos em tempos distintos;

- Contínuo e Discreto - um sistema é dito contínuo quando os fenômenos são considerados contínuos no tempo e discretos quando as mudanças de estado são realizadas em intervalos discretos;

- Concentrado e Distribuído - um modelo é distribuído quando leva em conta a variabilidade espacial do sistema e concentrado quando a mesma não é considerada;

- Estocástico e Determinístico - um modelo é dito estocástico quando as

• PORTO, R.L.L.; AZEVEDO, L.G.T. (1997). Sistemas de Suporte a Decisões Aplicados a Problemas de Recursos Hídricos. In: PORTO, R.L.L., org. Técnicas Quantitativas para Gerenciamento de Recursos Hídricos. Porto Alegre, UFRGS/ABRH. Cap. 2, p.43-96 apud MAIA, A.G. (2002). Simulação em Tempo Real como Ferramenta de Decisão no Gerenciamento de Estoques de Água de Reservatórios. p.143. Dissertação (Mestrado) Escola de Engenharia de São Carlos - Universidade de São Paulo. São Carlos, 2002. 
variáveis são consideradas em termos de probabilidade e determinístico quando esta consideração não é feita;

- Conceitual e Empírico - os modelos conceituais são elaborados utilizando as funções que descrevem os processos físicos. Os modelos empíricos ajustam os valores calculados aos valores observados, através de funções que não têm relação com os processos físicos desenvolvidos, sendo utilizados, na maioria das vezes, como modelos tipo "caixa-preta".

Porto e Azevedo ${ }^{*}$ (1997 apud MAIA, 2002, p.143) relatam algumas das vantagens da utilização de um modelo:

- Análise do sistema real (quando possível) é muito mais cara do que a utilização do modelo;

- O custo de cometer erros e realizar experiências com o sistema real é incomparavelmente maior do que o custo da exploração intensa do modelo;

- Modelos são ferramentas de aprendizagem uma vez que processos de tentativa e erro podem ser explorados "gratuitamente" e não só contribuem para a melhor compreensão do sistema, mas também estimulam a concepção de novas idéias e linhas de ação;

- Modelos são instrumentos muito eficientes para treinamentos quando desenvolvidos ou adaptados especificamente para esta finalidade;

- Modelos conferem flexibilidade às análises, porque:

○ "Encurtam" o tempo, pois permitem que muitos anos sejam analisados em tempos extremamente curtos;

- Diferentes alternativas podem ser analisadas, muitas vezes mediante simples alterações de parâmetros.

Um modelo só deve ser utilizado quando se tem conhecimento dos fenômenos que regem o sistema, das simplificações feitas durante a modelagem e da exatidão dos

\footnotetext{
' PORTO, R.L.L.; AZEVEDO, L.G.T. (1997). Sistemas de Suporte a Decisões Aplicados a Problemas de Recursos Hídricos. In: PORTO, R.L.L., org. Técnicas Quantitativas para Gerenciamento de Recursos Hídricos. Porto Alegre, UFRGS/ABRH. Cap.2, p.43-96 apud MAIA, A.G. (2002). Simulação em Tempo Real como Ferramenta de Decisão no Gerenciamento de Estoques de Água de Reservatórios. p.143. Dissertação (Mestrado) Escola de Engenharia de São Carlos - Universidade de São Paulo. São Carlos, 2002.
} 
dados de saída. Sendo assim, o usuário pode analisar se o modelo é satisfatório, em função do objetivo para o qual foi construído.

As limitações básicas dos modelos hidrológicos são a quantidade e a qualidade dos dados hidrológicos, além da dificuldade de formular matematicamente alguns processos e a simplificação do comportamento espacial das variáveis e fenômenos.

Os modelos usualmente são classificados em: físicos, analógicos e matemáticos. O modelo físico representa o sistema por um protótipo em escala menor, na maior parte dos casos. Os modelos analógicos valem-se da analogia das equações que regem diferentes fenômenos, para modelar no sistema mais conveniente, o processo desejado.

Os modelos matemáticos são os que representam a natureza do sistema, através de equações matemáticas. Estes modelos são mais versáteis, porque se pode facilmente modificar a sua lógica, obtendo-se resultados de diferentes situações de um mesmo sistema ou de diferentes sistemas, além da grande velocidade de resposta. A desvantagem deste tipo de modelo está na discretização de processos contínuos e na dificuldade na representação matemática de alguns processos físicos. Os modelos matemáticos, também conhecidos como digitais, serão aqui tratados, por eles fazerem parte do objetivo deste estudo.

O uso de modelos matemáticos em hidrologia iniciou e foi impulsionada pela divulgação de pacotes de programas que permitem fácil acesso, mas nem sempre uma boa compreensão da metodologia, suas vantagens e, principalmente, suas limitações. A utilização destes modelos e especialmente, em drenagem urbana começou na década de 1960, quando pesquisadores sentiram que os computadores digitais poderiam ser utilizados com muitas vantagens, para simular processos hidrológicos. Desde então, os meios técnicos presenciaram o aparecimento de grande número de modelos, dos mais simples aos mais complexos.

\subsubsection{Modelo ABC}

Segundo Porto et al. (1993 apud TUCCI, 2001, p.943) o modelo ABC é um conjunto de métodos hidrológicos clássicos que funcionam articuladamente e são

' PORTO, R.; ZAHED FILHO, K.; GIKAS, A.N. (1993). ABC3 - Análise de Cheias Complexas. Manual do Usuário, São Paulo: Fundação Centro Tecnológico de Hidráulica apud TUCCI, C.E.M. (2001). Hidrologia Ciência e Aplicação. Associação Brasileira de Recursos Hídricos (ABRH), Porto Alegre: Ed. Universidade/UFRGS, $2^{a}$ ed., p.943. 
apoiados por interfaces de diálogo com o usuário, rotinas gráficas e um banco de dados de relações intensidade-duração-freqüência de todo o Brasil.

De acordo com Tucci (2001), o modelo ABC aplica-se a problemas de drenagem urbana, em especial aos que podem ser classificados como sendo de macrodrenagem. Sua aplicação apresenta vantagens sobre o conhecido método racional, pois se aplica sem restrições a bacias com áreas de drenagem superiores a 100 ha. Apesar disso, o modelo $\mathrm{ABC}$ se aplica a bacias com áreas inferiores, bem como a grandes bacias urbanas (superiores a $50 \mathrm{Km}^{2}$ ), segmentando-se a bacia, para considerar a diversidade de distribuição da chuva e ocupação do solo.

O modelo está escrito em linguagem Quick Basic, versão 4.5. Pode ser executado em computadores compatíveis com o IBM-PC, em sua configuração mínima.

\subsubsection{Modelo ABC 4}

Segundo Vicentini (2000), o Modelo ABC 4 destina-se a determinação de hidrogramas de cheia executando ainda, outras funções relativas aos projetos de macrodrenagem. Sua aplicação é voltada para bacias de médio porte, para os casos em que o método racional não se aplica (áreas de drenagem de 500 a $1000 \mathrm{Km}^{2}$ ).

As restrições do modelo são:

- A chuva de projeto deverá ser uniformemente distribuída por toda área da bacia. Caso isto não ocorra, a bacia deverá ser fragmentada em subbacias com precipitações diferentes;

- O efeito do armazenamento nos canais não deve ser significativo;

- Deverá ser levado em consideração o efeito da variação da intensidade da chuva de projeto ao longo do tempo.

O programa $\mathrm{ABC} 4$ é composto de cinco módulos cada um composto de conjunto de partes que se relacionam funcionalmente. Os cinco módulos são:

- Módulo 1 - Dados da bacia - É o módulo de entrada de dados da bacia;

- Módulo 2 - Precipitação - Reúne todas as funções à determinação da precipitação de projeto; 
- Módulo 3 - Hidrogramas - Este módulo são executadas as funções relativas aos hidrogramas;

- Módulo 4 - Amortecimento - Este módulo é possível calcular o amortecimento em canais (método de Muskingum) e reservatórios;

- Módulo 5 - Utilitários - Este módulo permite a execução de rotinas auxiliares como, por exemplo, acesso ao sistema operacional, processador de texto, gerenciador de arquivos, etc.

\subsubsection{Modelos IPH}

Segundo Tucci (1998), estes modelos foram desenvolvidos no Instituto de Pesquisas Hidráulicas da Universidade Federal do Rio Grande do Sul, para simulação de parte do processo do ciclo hidrológico. A numeração dada a cada modelo foi de acordo com a versão e estes modelos são aplicáveis a diferentes situações, e estão especificados a seguir:

Modelo IPH II - tem como objetivo o uso para projetos de engenharia em bacias urbanas e rurais. Além disso, utiliza poucos parâmetros e é baseado em metodologias conhecidas. Esta versão é utilizada para bacias que não necessitem propagação no leito do rio ou que este efeito não seja importante no processo. A propagação considerada neste modelo se refere apenas ao escoamento na superfície da bacia;

Modelo IPH III - simula o escoamento na bacia e propaga as vazões que chegam ao rio pelo método da onda cinemática, através da utilização da versão anterior. Outras opções foram adicionadas como: Muskingun-Cunge para rios e o método de Pulz para reservatório. A entrada da contribuição da bacia é distribuída por sub-trechos na simulação. Esta versão do modelo admite a simulação de um sistema fluvial onde, no canal, não existam efeitos devido à maré ou lagos que provoquem remanso ou inversão de fluxo;

Modelo IPH IV - simula o escoamento na bacia a partir da segunda versão e utiliza um modelo hidrodinâmico, que usa um esquema implícito de diferenças finitas para simular o escoamento no rio e reservatórios. 
Tucci (1998), indica também uma versão deste modelo que simula o processo precipitação-vazão com intervalo de tempo mensal. Esta versão é denominada de IPH mensal e foi proposto com o objetivo de obter resultados rápidos com um certo grau de aproximação para problemas básicos de balanço hídrico. 


\section{MATERIAIS E MÉTODOS}

\subsection{Introdução}

Para alcançar os objetivos propostos, inicialmente se atualizou o Modelo EESC, para reavaliar a influência do grau de impermeabilização das bacias dos córregos do Gregório, Tijuco Preto e Mineirinho, e do Rio Monjolinho. Além disso, foi feita uma nova discretização do conjunto de sub-bacias para uso deste modelo com alterações no código do programa, para inserir dois outros métodos de cálculo dos hidrogramas de cheias, o método de Nash (1960) e o método de regionalização de Diaz e Tucci (1989).

A rede de macrodrenagem de São Carlos (ANEXO C) foi modificada com a nova discretização realizada (ANEXO D), com isso o número de sub-bacias aumentaram e conseqüentemente o número de trechos. Devido à nova discretização, a alteração feita nos arquivos de dados do modelo EESC, necessitou do levantamento das seções transversais de alguns córregos, para a determinação dos coeficientes $\alpha$ e $\beta$ do método da onda cinemática.

Os dois métodos implantados, que fizeram criar dois novos programas e o método do Soil Conservation Service (SCS), já presente na versão atual do modelo EESC, foram utilizados para um estudo de comparação e avaliação entre os três hidrogramas de cheias obtidos a partir dos três métodos utilizados, através do modelo EESC.

Foram feitos ainda estudos comparativos e avaliações entre os hidrogramas de cheias simulados, para algumas bacias de interesse da rede de macrodrenagem de São Carlos, em relação às condições de inundações em que a cidade apresentou no decorrer de longos anos. Devido à isso, simulou-se o comportamento hidrológico nos pontos críticos para cada bacia nas condições atuais e futuras. 
A comparação entre os três métodos foi feita a partir de determinadas situações, que se mantiveram inalteradas, de modo que os resultados pudessem ser cotejados. As sub-bacias escolhidas foram analisadas nas seguintes condições:

a) Equação intensidade-duração-freqüência utilizada para a cidade de São Carlos, BARBASSA (1991).

$i=\frac{1519 T r^{0,236}}{(t+16)^{0,935}}$

onde $\mathrm{i}$ - intensidade, em $\mathrm{mm} / \mathrm{h} ; \mathrm{Tr}$ - período de retorno, em anos; $\mathrm{t}$ - tempo de duração da chuva, em minutos.

b) A distribuição temporal local da chuva, para um determinado período de retorno, foi feita aplicando-se um método de blocos alternados, que rearranjou os incrementos de chuva, de duração $\mathrm{D}$, na forma, $\mathrm{P}_{6}, \mathrm{P}_{3}, \mathrm{P}_{1}, \mathrm{P}_{2}, \mathrm{P}_{4}, \mathrm{P}_{5}, \mathrm{P}_{7}, \mathrm{P}_{8}$, etc. $\mathrm{O}$ hietograma de chuva efetiva acoplado aos métodos do SCS, Nash e o de regionalização de Diaz e Tucci, foi determinado através da especificação do número de deflúvio $(\mathrm{N})$, para cada sub-bacia, e cujo escoamento superficial direto é dado por:

$\operatorname{Re}=\frac{(R-5080 / N+50,8)^{2}}{(R+20320 / N-203,2)}$

onde Re - excesso de chuva, em milímetro; $\mathrm{R}$ - precipitação, em milímetros; N número de deflúvio que define o complexo hidrológico solo-vegetação (o CN utilizado em algumas literaturas é o $\mathrm{N}$ utilizado neste estudo).

c) O tempo de concentração das sub-bacias foi determinado pela expressão de George Ribeiro, (RIBEIRO, 1961).

$$
t c=\frac{16 L}{(1,05-0,2 p)(100 I)^{0,04}}
$$


onde tc - tempo de concentração, em minutos; L - comprimento do talvegue, em Km; p - a relação entre a área coberta de vegetação e a área total da sub-bacia; I - declividade média do talvegue, em \%, calculada pelo método "I15\%-85\%", Wilson (1983).

\subsection{O modelo EESC}

O modelo hidrológico distribuído, denominado EESC, desenvolvido por Righetto e Porto (1994), considera a real necessidade de métodos hidrológicos simples, facilmente entendíveis, que não requer grande esforço computacional e possanser facilmente aplicável em situações locais.

Construído com essas características, o modelo EESC tem como objetivo resolver os problemas relativos aos efeitos do aumento da urbanização e analisar a bacia como um todo ou uma determinada seção de interesse. Este é um modelo computacional hidráulico-hidrológico, específico para a área urbana da cidade de São Carlos, e que abrange todas as bacias dos córregos do Gregório e do Monjolinho até a seção do pontilhão da FEPASA, alcançando cerca de $76,079 \mathrm{~km}^{2}$.

Esta área foi dividida em 54 bacias, trechos e seções de interesse, dos quais foram levantados os parâmetros hidráulicos, hidrológicos e topográficos. Dessa maneira, o modelo permite a análise em qualquer ponto da rede de drenagem, através de hidrogramas de cheias em função de um período de retorno especificado, constituindo assim, num modelo distribuído de grande interesse para o planejamento da rede de macrodrenagem urbana.

As ocupações crescentes de áreas poderão ser simuladas pelo modelo, através de alterações das características de ocupação e uso do solo da área específica em estudo. O modelo será aplicado em estudos de planejamento urbano enfocando problemas decorrentes do efeito da urbanização na rede de drenagem, analisando o comportamento da área de interesse em diferentes situações da evolução do crescimento urbano.

Melhorias no sistema de drenagem, tais como, retificação e canalização poderão ser avaliadas pelo modelo, através de alterações dos parâmetros hidráulicos dos trechos que sofreram modificações. O modelo fornece, também, subsídios para projetos de obras de drenagem.

O modelo EESC configura a rede de drenagem de modo a acoplar todas as subbacias a nós ou seções de rede de canais, gera hidrogramas de sub-bacias e propaga 
ondas de cheias ao longo dos canais principais.

Além disso, o modelo é composto de três partes. A primeira define numericamente a configuração da rede de drenagem e acopla todas as sub-bacias de cabeceiras e intermediárias a nós ou seções da rede de canais. Na segunda, com os principais parâmetros hidrológicos básicos de cada sub-bacia, obtém a transformação da chuva em vazão por meio de metodologias estabelecidas: o método do SCS, o método de Nash e o método de regionalização de Diaz e Tucci, para se fazer uma avaliação final, depois de gerados os hidrogramas de cheias para todas as sub-bacias, método a método. A terceira considera a capacidade de transporte dos canais, por meio do "routing" de cheia.

\subsubsection{Configuração da rede de drenagem}

A cidade de São Carlos está localizada nas cabeceiras do Córrego do Monjolinho, tendo como afluente principal o Córrego do Gregório, o qual atravessa a parte mais densa da cidade.

A rede de macrodrenagem em estudo é formada pelos córregos do Monjolinho, Gregório, Tijuco Preto, Mineirinho e Santa Maria Madalena. A sua configuração subdivide-se em tramos e trechos, constituída de 54 sub-bacias e 7 tramos. Os tramos subdividem-se em trechos definidos por seções e acoplados às seções tem as sub-bacias, de cabeceiras e intermediárias. A Figura 13 mostra uma bacia composta de uma rede de canais principais com três tramos e 11 sub-bacias. O tramo 1 está sub-dividido em dois trechos e definidos pelas seções 1.1, 1.2 e 1.3; acoplado à seção 1.1 tem-se a sub-bacia de cabeceira 1.1.1, à seção 1.2, a sub-bacia intermediária 1.2.1 e a de cabeceira 1.2.2; e à seção 1.3 a sub-bacia intermediária 1.3.1. Para o tramo 2, tem-se também dois trechos definidos pelas seções $2.1,2.2$ e 2.3 com suas sub-bacias correspondentes. $\mathrm{O}$ terceiro tramo, com dois trechos definidos pelas seções 3.1, 3.2 e 3.3 completa a rede de canais; ligada à seção 3.2, tem-se a sub-bacia intermediária 3.2.1 e a de cabeceira 3.2.2; à seção 3.3 a sub-bacia intermediária 3.3.1. Os tramos 1 e 2 são independentes, enquanto que o tramo 3 depende dos tramos 1 e 2 . O ANEXO C, mostra a rede de canais e a numeração das seções e sub-bacias, discretizada para a cidade de São Carlos. 


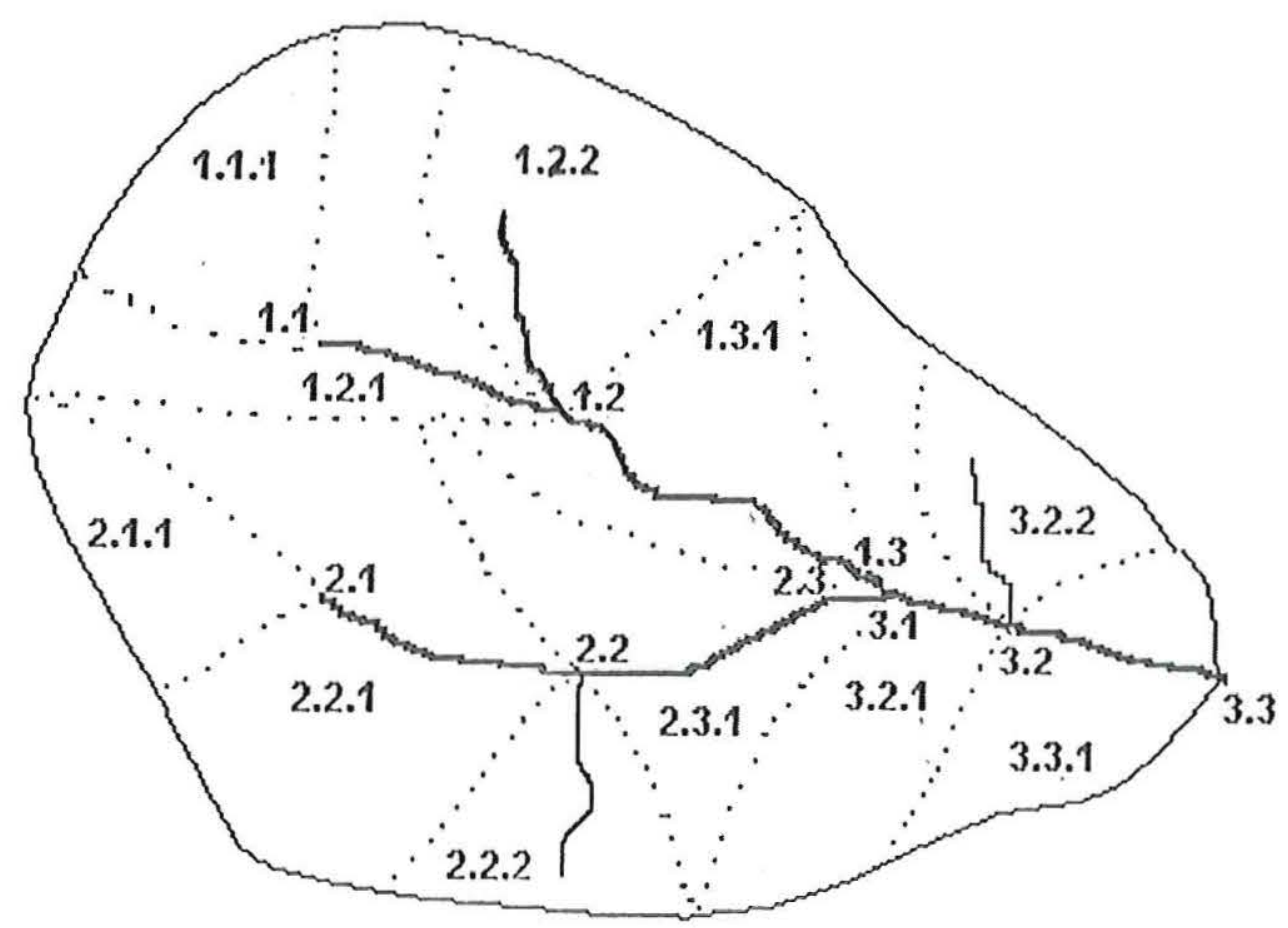

Figura 13 - Configuração de uma bacia de drenagem.

Fonte: Righetto e Porto (1994, p.16).

\subsubsection{Transformação chuva-vazão}

Devido à falta de séries históricas de registros de vazões em nossas bacias urbanas, utilizadas neste projeto de macrodrenagem, foi desenvolvida a técnica do Hidrograma Unitário Sintético, para gerar hidrogramas de projeto.

Os HUS são classificados como empíricos e conceituais. Neste trabalho optou-se por dois hidrogramas empíricos, o triangular do Soil Conservation Service e o de regionalização de Diaz e Tucci, e um conceitual que é o hidrograma de Nash, para geração de hidrogramas de projeto, de todas as sub-bacias de cabeceira do sistema de drenagem urbana da cidade de São Carlos.

\section{Método do SCS}

Escolhido nesse estudo por sua simplicidade, praticidade e familiaridade entre os profissionais da área, esse método foi desenvolvido para pequenas bacias rurais $\mathrm{e}$ eventos chuvosos diários, mas tem sido adaptado para as condições urbanas, pelo 
estabelecimento de valores do parâmetro "número de deflúvio", para bacias urbanas e suburbanas, (LINDLEY, 1976).

O Departamento de Conservação do Solo norte-americano, SCS, realizou inúmeros experimentos em bacias de pequeno porte, com o objetivo de estabelecer relações entre a precipitação, o deflúvio superficial, grau de vegetação e o tipo e ocupação do solo (RIGHETTO, 1998).

Segundo Wilken (1978), o método do Hidrograma Unitário do Soil Conservation Service foi desenvolvido pelo Engenheiro Victor Mockus, U. S. Soil Conservation Service, em 1952. Ele desenvolveu um método para construir um Hidrograma Unitário sintético, baseado em um hidrograma adimensional, este gráfico adimensional é o resultado da análise de um grande número de HU naturais de bacias de variadas extensões e localizações geográficas nos Estados Unidos.

O Serviço de Conservação de Solo dos EUA desenvolveu esta metodologia visando uma aplicação prática e segura, para regiões onde não se disponha de dados históricos de vazão. A partir de dados topográficos e geomorfológicos disponíveis da região em estudo, este Hidrograma Unitário Sintético é representado por um triângulo, e obtido com base na vazão de pico e tempo de pico, conforme apresentado na Figura 14.

O Hidrograma Unitário Triangular (HUT) é uma conversão do gráfico curvilíneo, ou seja, do Hidrograma Unitário (HU) em um triângulo, com o mesmo total de escoamento, o mesmo máximo e o tempo para o mesmo.

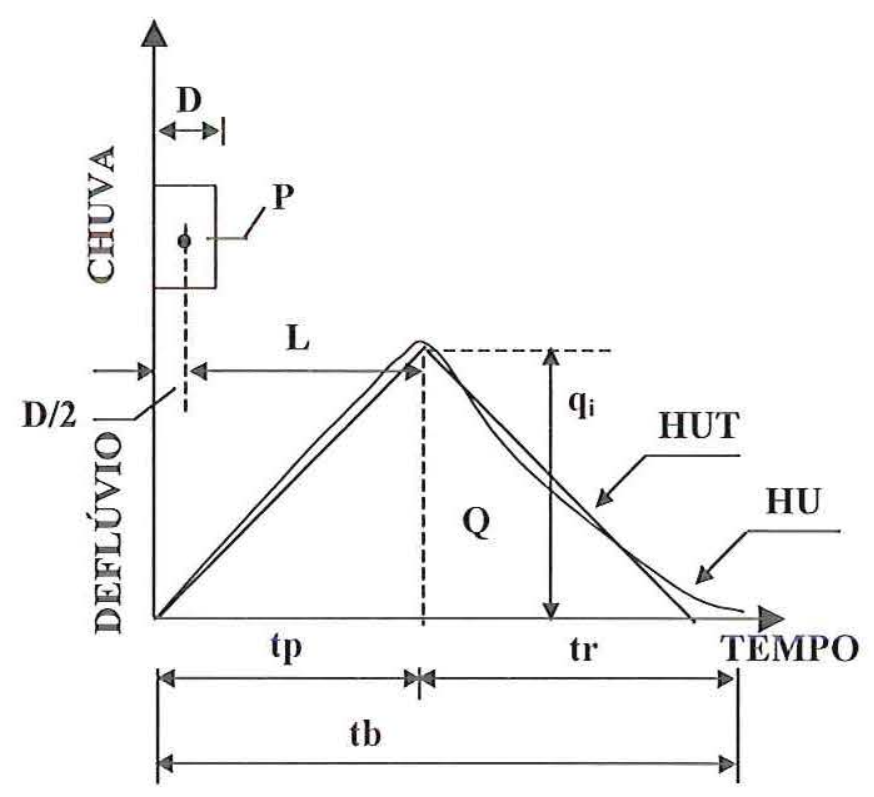

Figura 14 - Hidrograma Unitário Sintético Triangular

Fonte: Wilken (1978, p.194). 
HUT - Hidrograma Unitário Triangular;

HU - Hidrograma Unitário curvilíneo;

$\mathrm{P}$ - precipitação em cm que produziu o HU;

D - duração da precipitação, em horas;

tp - tempo de pico, em horas;

tr - tempo de recessão, em horas;

$\mathrm{tb}=\mathrm{tp}+\mathrm{tr}-$ tempo de base do hidrograma, em horas;

$\mathrm{L}$ - tempo de retardamento da bacia, em horas;

tc - tempo de concentração da bacia, em horas;

$\mathrm{q}_{\mathrm{i}}$ - vazão de pico, em cm/h;

$\mathrm{Q}$ - vazão máxima, em $\mathrm{m}^{3} / \mathrm{s}$ - área do hidrograma $=1$;

A partir da Figura 14 se obtém:

$Q=\frac{q_{i} t_{p}}{2}+\frac{q_{i} t_{r}}{2}$

ou

$q_{i}=\frac{2 Q}{t p+t r}$

onde $\mathrm{q}_{\mathrm{i}}$ - vazão de pico, em $\mathrm{cm} / \mathrm{h} ; \mathrm{Q}$ - vazão máxima, em $\mathrm{m}^{3} / \mathrm{s} ; \mathrm{tp}$ - tempo de pico, em horas; tr - tempo de recessão, em horas.

O tempo de recessão (tr) é estimado baseado no tempo de pico (tp) e é dado por:

$t r=1.67 t p$

onde o valor 1.67 é uma constante determinada para o tipo da bacia em estudo, que a partir de extensas pesquisas o Soil Conservation Service concluiu que pelo valor médio geral, este seria o valor determinado.

Com isso, ao introduzir a eq. (4.6) na eq. (4.5) se tem: 


$$
q_{i}=\frac{2 Q}{2.67 t p}
$$

Também, por experiência obteve o retardamento: $\mathrm{L}=0,6 \mathrm{t}_{\mathrm{c}}$

Portanto: $t_{p}=D / 2+L \rightarrow t_{p}=D / 2+0,6 t_{c}$

Ao converter $q_{i}$ que está em $\mathrm{cm} / \mathrm{h}$ para $\mathrm{m}^{3} / \mathrm{s}$, e inserindo a área de drenagem (A) $\mathrm{em} \mathrm{Km}{ }^{2}\left(1 \mathrm{~cm} / \mathrm{h}=2,78 \mathrm{~m}^{3} / \mathrm{s} . \mathrm{Km}^{2}\right)$, a eq. 4.7 fica:

$$
q_{p}=\frac{2 * 2,78 * A Q}{2,67 t p}
$$

ou

$$
q_{p}=\frac{2,08 A Q}{t p}
$$

onde $\mathrm{q}_{\mathrm{p}}$ - vazão de pico, em m³ $/ \mathrm{s} ; \mathrm{A}$ - área de drenagem, em $\mathrm{Km}^{2}$; tp - tempo de pico, em horas.

Como a quantidade de chuva excedente ou de escoamento direto é: $\mathrm{P}=\mathrm{Q}=1 \mathrm{~cm}$ e substituindo $Q=1$ na eq. 4.9 temos:

$$
q_{p}=\frac{2.08 A}{t p}
$$

\section{Método de Nash}

O método determinado por Nash para obter o Hidrograma Unitário Instantâneo (HUI) é dado pela equação a seguir (NASH, 1960):

$u(t)=\frac{1}{K \Gamma(n)} e^{-t / K}\left(\frac{t}{K}\right)^{n-1}$

A equação da "curva-S" é: $S(t)=\int_{0} u(t) d t$ 


$$
\text { Então: } \begin{aligned}
S(t) & =\frac{1}{\Gamma(n)} \int_{0}^{/ K} e^{-t / K}\left(\frac{t}{K}\right)^{n-1} d\left(\frac{t}{K}\right) \\
S(t) & =I(n, t / K)
\end{aligned}
$$

onde, I (n, t/K) é a Função Gama Incompleta de ordem n para t/K.

O HU de duração T é dado por:

$$
\begin{aligned}
& u(T, t)=\frac{1}{T}[s(t)-s(t-T)] \\
& u(T, t)=\frac{1}{T}[I(n, t / K)-I(n,(t-T) / K)]
\end{aligned}
$$

que é a equação geral do HU de duração T.

A Função Gama Incompleta foi aproximada pelo somatório, Grandshtein e Ryzhik (1965):

$$
I(n, t / K)=\frac{1}{\Gamma(n)} \sum_{i=0}^{\infty} \frac{(-1)^{i}(t / K)^{n+1}}{i !(n+i)}
$$

Segundo Tucci (1998) para as bacias onde não existem dados observados, como é o caso deste trabalho, Nash (1959) apresentou duas equações derivadas com base em 90 eventos de 30 bacias britânicas com área que varia entre 4,8 e 859 milhas quadradas.

De acordo com Porto e Righetto (1995), com base em Nash (1960), os parâmetros da distribuição $n, K$ estão relacionados com as características fisiográficas da bacia, como segue:

$$
n=\frac{L^{0.1}}{0,43}
$$

e

$$
K=\frac{8,921 A^{0.3}}{\left(S^{0.3} L^{0.1}\right)}
$$


onde, L - é o comprimento do curso d'água principal, em Km; A - a área da bacia, em $\mathrm{Km}^{2} ; \mathrm{S}-$ a declividade média do talvegue, em partes por 10.000 .

\section{Método de Regionalização de Diaz e Tucci}

De acordo com Diaz e Tucci (1989), a partir dos resultados alcançados, o quarto grupo da Tabela 10, da página 54, foi o que apresentou melhores resultados com boas estimativas e menores erros fatoriais, tanto para a vazão de pico como para os outros parâmetros envolvidos na definição do HU, com exceção da equação do tempo de pico, em que o erro fatorial foi maior que o do grupo três. Apesar disto, os grupos três e quatro apresentaram poucas diferenças entre si no tocante às estatísticas.

Na utilização deste método para simulação dos hidrogramas de cheias se optou pelo primeiro grupo, pois em relação à Tabela 9 , da página 53, as dezenove bacias brasileiras estavam incluídas neste grupo.

O HU é definido com base nas variáveis Qp, tp, $\mathrm{L}_{50}$ e $\mathrm{L}_{25}$ (Grupo I, Tabela 10), sendo que o tempo de base (tb) é obtido com base no volume unitário do HU. A Figura 15 apresenta o posicionamento dos parâmetros do HU regionalizado de Diaz e Tucci.

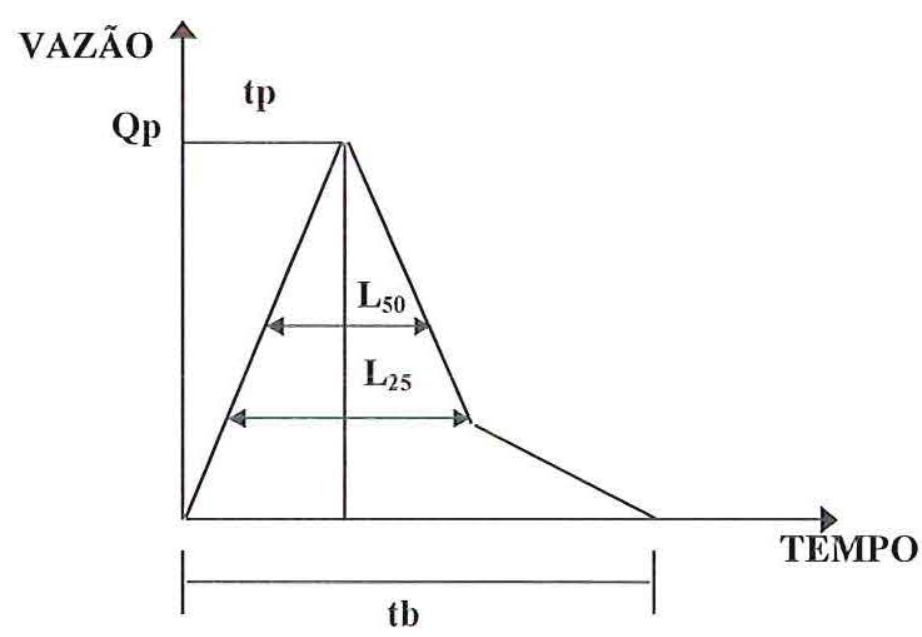

Figura 15 - Posicionamento dos parâmetros do HU regionalizado de Diaz e Tucci.

Fonte: Diaz e Tucci (1989, p.26).

4.2.3 Propagação de cheia

Utiliza-se o método de onda cinemática para o cálculo de propagação de cheias 
na rede de canais principais. Este método foi escolhido por sua simplicidade e adequação para canais urbanos com declividades acentuadas. O método está baseado na equação da continuidade e na relação funcional entre seção molhada e vazão (LI et al., 1976).

A partir da seção de montante do primeiro trecho, cada tramo independente, realiza-se o cálculo de propagação, tomando-se como dados de entrada os hidrogramas correspondentes às sub-bacias. Cada trecho do canal é definido por meio de dois parâmetros $\alpha$ e $\beta$, que relacionam área molhada $A$ e vazão $Q$, representados na equação abaixo:

$\mathrm{A}=\alpha \mathrm{Q}^{\beta}$

Os parâmetros $\alpha$ e $\beta$ são obtidos a partir da geometria da seção do canal, da declividade de fundo I e do coeficiente de rugosidade n da equação de Manning.

A equação de Manning é válida para os escoamentos permanentes, uniformes e turbulentos rugosos, com grande número de Reynolds. A equação a seguir será a base de cálculo para os problemas sobre escoamentos livres.

$$
\frac{n Q}{\sqrt{I}}=A R_{h}^{2 / 3}
$$

onde $\mathrm{n}$ - coeficiente de rugosidade de Manning; Q - vazão, em $\mathrm{m}^{3} / \mathrm{s}$; I - declividade de fundo do canal, em m/m; A - área da seção do canal, em $\mathrm{m}^{2} ; \mathrm{Rh}$ - raio hidráulico, em metros.

O Raio Hidráulico $\left(R_{h}\right)$ é a relação entre a área molhada $\left(A_{m}\right)$ e o perímetro molhado $\left(\mathrm{P}_{\mathrm{m}}\right)$ da seção e deve-se observar que a fórmula de Manning, além de ter uma origem empírica, carrega um coeficiente "n" que não é um adimensional.

Substituindo a relação $R_{h}=\frac{A_{m}}{P_{m}}$ na equação 4.18 se tem:

$\frac{n Q}{\sqrt{I}}=\frac{A^{5 / 3}}{P^{2 / 3}}$ 
A área molhada e o perímetro molhado, de cada seção relacionam-se por:

$P=a_{1} A^{b 1}$

onde, a1 e b1 - são parâmetros específicos para cada trecho do canal.

A partir das equações $4.17,4.19$ e 4.20 é que se vai obter os parâmetros $\alpha$ e $\beta$, do método da onda cinemática. Ao substituir a equação 4.20 na 4.19 obtém:

$A=\left(\frac{n}{\sqrt{I}} a_{1}^{2 / 3}\right)^{\frac{3}{5-2 b_{1}}} Q^{3 / 5-2 b_{1}}$

Então, comparando a equação (4.21) com a equação (4.17), temos que:

$$
\begin{aligned}
& \alpha=\left(\frac{n}{I} a_{1}^{2 \beta}\right)^{3 /\left(5-2 b_{1}\right)} \\
& \beta=\frac{3}{5-2 b_{1}}
\end{aligned}
$$

Os dados necessários para cálculo da propagação ao longo de cada trecho são os seguintes: parâmetros $\alpha$ e $\beta$, comprimento do trecho do canal, intervalo de tempo adotado para o cálculo, vazão de base e hidrograma de entrada.

A propagação de cheia ao longo de um tramo é feita de montante para jusante, trecho a trecho. A propagação, ao longo dos tramos dependentes, é realizada após a obtenção de hidrogramas nas seções de extremidade dos tramos independentes.

\subsection{Utilização do modelo EESC}

O modelo matemático para a simulação hidrológica do sistema de macrodrenagem da cidade de São Carlos, neste caso, denominado modelo EESC, está programado em linguagem FORTRAN, e é constituído de um programa principal, denominado Drenagem Urbana, que utiliza duas sub-rotinas imbutidas no programa 
principal. A sub-rotina SCS foi programada para gerar hidrogramas de cheias nas subbacias de um sistema de macrodrenagem, onde utiliza o procedimento do Soil Conservation Service, para gerar hidrogramas sintéticos. A sub-rotina PROPAG permite que o programa EESC realize a propagação de cheias ao longo dos canais principais do sistema de drenagem.

Para se fazer a simulação de hidrogramas de cheias em um sistema de macrodrenagem qualquer, restrito a bacias cujos escoamentos em canais possam ser expressos por modelo cinemático, são utilizados quatro arquivos de dados, denominados CHUVAD, DREDAD, SUBDAD E TREDAD.

A utilização do modelo é extremamente simples, uma vez que os dois arquivos de dados; SUBDAD e TREDAD, podem ser facilmente manipulados quando se deseja fazer modificações substanciais na entrada dos dados do modelo. No entanto, caso se queira fazer uma simulação, mudando-se, apenas, alguns valores do coeficiente de deflúvio $(\mathrm{N})$ e do grau de vegetação (PP) de uma sub-bacia ou ainda, valores de alfa $(\alpha)$ e beta $(\beta)$ de alguns trechos da rede de canais, essas alterações de dados podem ser realizadas diretamente pelo teclado, através de um procedimento de conversão concebido para este modelo. Para se realizar qualquer simulação, o programa do modelo EESC solicita, via tela, a especificação do período de retorno (TR) e da duração da chuva (DC). O modelo permite 2 saídas :

- Via tela: Tabela ou Gráfico;

- Via arquivo.

\section{Arquivo CHUVAD}

O arquivo CHUVAD alimenta o modelo EESC com dados da chuva de projeto selecionada para simulação da drenagem do sistema urbano. As variáveis do programa, relacionadas com este arquivo de dados são os seguintes:

NTEMP: número de intervalos de tempo;

TR: período de retorno selecionado, em anos;

DC: duração da chuva, em horas;

D: intervalo de tempo, em horas;

XK, B, C, T0: parâmetros da equação intensidade-duração-freqüência do local 
em estudo, expressa por:

$i=\frac{X K^{*} T R^{B}}{(60 * D C+T 0)^{C}}$

\section{Arquivo DREDAD}

$\mathrm{O}$ arquivo DREDAD possui os dados da configuração da rede de drenagem. As seguintes variáveis foram definidas para este arquivo:

NTR: número de tramos da rede de canais principais;

NS(I), I=1, NTR: número de seções por tramo;

J1(I), J2(I), I=1, NTR: dois possíveis tramos de montante conectados diretamente com o tramo I. O número zero indica ausência de tramo de montante.

NSB(I,J), I=1, NTR e J=1, NS(I): número de sub-bacias acopladas ao nó ou seção J do tramo I; no máximo, três sub-bacias podem estar acopladas a uma seção.

\section{Arquivo SUBDAD}

$\mathrm{O}$ arquivo SUBDAD fornece os dados relativos às sub-bacias do sistema de macrodrenagem. Para cada sub-bacia são lidos os valores das seguintes variáveis, que são utilizadas para a leitura deste arquivo:

IISUB: número da sub-bacia;

$\mathrm{N}$ : número de deflúvio;

L: comprimento do talvegue ou do percurso principal do escoamento na subbacia, em Km;

PP: grau de cobertura vegetal da bacia;

S: declividade média do talvegue da sub-bacia:

A: área de drenagem da sub-bacia, em $\mathrm{Km}^{2}$.

\section{Arquivo TREDAD}

$\mathrm{O}$ arquivo TREDAD contém os dados dos trechos da rede de canais. As 
seguintes variáveis são utilizadas para a leitura deste arquivo:

NT: número do tramo da rede de canais;

I: número do trecho (igual da seção de jusante), I=1, NS(NT);

$\operatorname{ALF}(\mathrm{N}, \mathrm{T})$ : coeficiente da equação (9) para o trecho I;

BET(NT,I): expoente da equação (10) para o trecho I;

DDX(NT,I): comprimento do trecho I, em metros.

O ANEXO E apresenta o código do programa principal do modelo EESC com explicações, passo a passo, dos algoritmos básicos do programa e as respectivas subrotinas: SCS, TUCCI e NASH, utilizadas para gerar os hidrogramas de cheia. O ANEXO F apresenta os quatro arquivos de dados usados para a realização das simulações e o ANEXO G contém um disquete com o programa do modelo EESC.

\subsection{Modificação do modelo EESC}

Em linguagem Fortran, o Modelo EESC já desenvolvido, é formado por um programa principal e duas sub-rotinas, mencionadas no item anterior. A modificação efetuada no modelo foi inserir no lugar da sub-rotina SCS, a qual utiliza o método do Soil Conservation Service para gerar HU, duas outras sub-rotinas. A sub-rotina Nash, que utiliza o método de Nash (1960) e a sub-rotina de Diaz e Tucci, onde se utiliza o método apresentado por Diaz e Tucci (1989). A partir disso, três programas foram implementados com o nome de cada método utilizado, diferenciando um do outro apenas nas sub-rotinas referente a cada método, isso foi feito para analisar três métodos diferentes na avaliação e comparação dos Hidrogramas Unitários.

$\mathrm{O}$ arquivo de dados TREDAD, teve alguns valores de suas variáveis alterados, neste caso, os parâmetros $\alpha$ e $\beta$, que são indispensáveis para o cálculo da propagação ao longo de cada trecho. Estas variáveis foram determinadas a partir de mapas com curvas de níveis da cidade de São Carlos, através de medidas de algumas seções do Rio Monjolinho, do Córrego do Tijuco Preto e do Córrego do Gregório. Seções estas, retiradas do relatório elaborado pelo Shs (1993), onde no ANEXO H está apresentado, em papel milimetrado, um dos perfis utilizados neste estudo e que está contido neste relatório. Como explicação do que se fez, a Figura 16 apresenta as seções referentes ao 
trecho 13.

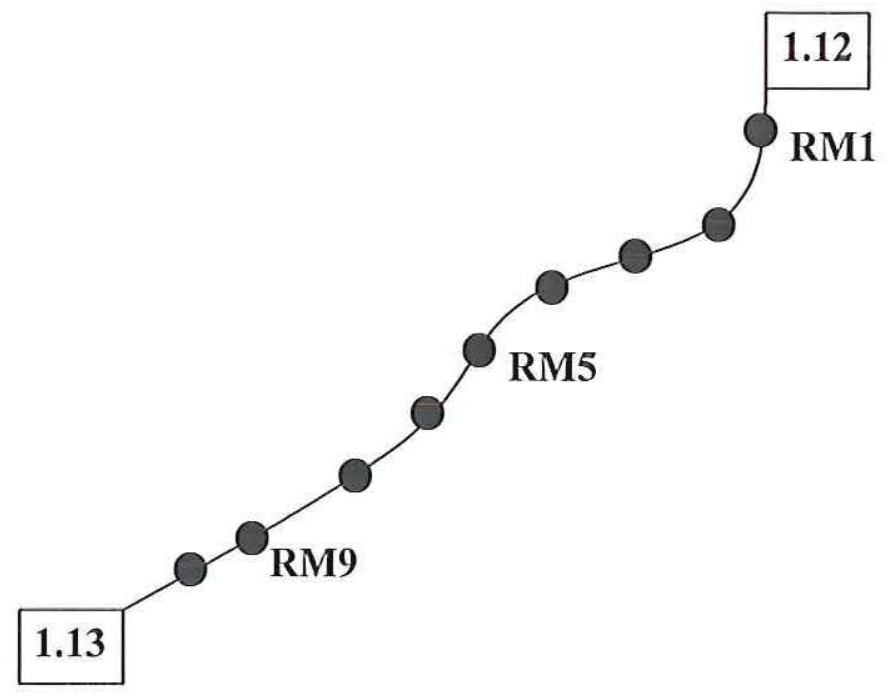

Figura 16 - Especificação das seções RM 1 a RM 9 do trecho 13, tramo 1, entre as seções 1.12 e 1.13 do Rio Monjolinho.

Inicialmente, para determinar estes parâmetros, utilizou o AutoCAD 2002 para construir os perfis das seções considerando vários níveis d'água. Como exemplo do que foi feito para todas as seções consideradas neste estudo, a Figura 17 representa uma seção com diferentes níveis d'água $(\mathrm{N})$.

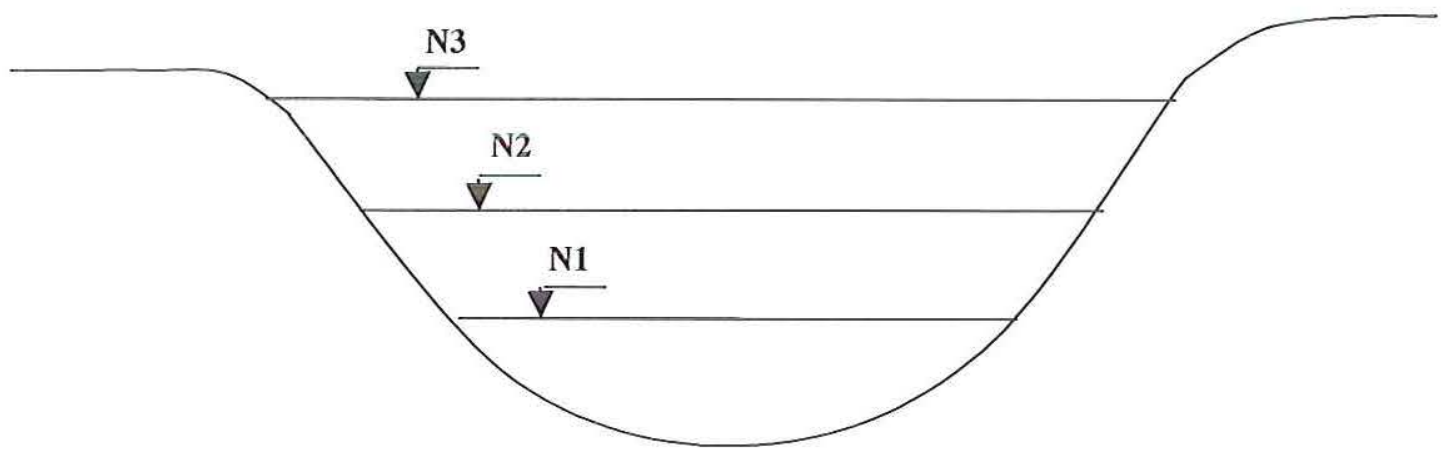

Figura 17 - Representação de uma seção transversal genérica, com 3 níveis d'água.

A seguir, foram determinados valores da área molhada e do perímetro molhado para cada seção, relacionados entre si pela equação $P=a_{1} A^{b 1}$, onde $a_{1}$ e $b_{1}$ são parâmetros específicos para cada trecho do canal. Estes parâmetros foram utilizados 
como variáveis de uma determinada função objetivo pela ferramenta Solver da planilha eletrônica Microsoft Excel, onde minimizou esta função e obteve os valores de $a_{1}$ e $b_{1}$. A função objetivo utilizada foi a seguinte:

$$
\sum_{i=1}^{n} \frac{\left(P_{i}^{\prime}-P_{i}\right)^{2}}{P_{i}}
$$

onde, $\mathrm{P}^{\prime}$ - é o perímetro molhado obtido por: $\mathrm{P}^{\prime}=\mathrm{a} 1^{*} \mathrm{~A} 1^{\wedge} \mathrm{b} 1 ; \mathrm{P}-$ perímetro molhado calculado através do Auto CAD.

Encontrados $a_{1}$ e $b_{1}$, determinou-se para cada trecho a declividade de fundo I do canal, e com o curvímetro calculou o comprimento do curso d'água principal (L), para poder aplicar a fórmula determinada para a declividade. A fórmula para o cálculo da declividade é:

$$
I=\frac{C_{1}-C_{2}}{L_{85 \%}-L_{15 \%}}
$$

onde, I - é a declividade em $\mathrm{m} / \mathrm{m} ; \mathrm{C}_{1}$ - é a cota a $15 \%$ do comprimento principal (L), em metros; $C_{2}$ - é a cota a $85 \%$ do comprimento principal (L), em metros; $L_{15 \%}-15 \%$ do comprimento principal (L), em metros; $\mathrm{L}_{85 \%}$ - $85 \%$ do comprimento principal (L), em metros.

Para o coeficiente de rugosidade "n" da equação de Manning, parâmetro necessário para a determinação dos coeficientes $\alpha$ e $\beta$, adotou-se valores para cada trecho, de acordo com as características físicas iniciais do canal. Os valores estão apresentados na Tabela 11, a seguir: 
Tabela 11 - Valores de " $n$ " para cada trecho.

\begin{tabular}{|c|c|c|c|}
\hline Local & $\begin{array}{c}\text { Seções dos } \\
\text { trechos }\end{array}$ & $\begin{array}{c}\text { Seções nos } \\
\text { Trechos }\end{array}$ & $\mathbf{n}$ \\
\hline $\begin{array}{c}\text { Rio Monjolinho } \\
\text { (RM) }\end{array}$ & $\begin{array}{c}1.1 \text { a } 1.14,3.1 \text { a } 3.2, \\
5.1 \text { a } 5.4,7.1 \text { a } 7.2\end{array}$ & RM 1 a RM 44 & 0,035 \\
\hline $\begin{array}{c}\text { Córrego do Tijuco } \\
\text { Preto (CT) }\end{array}$ & 4.1 a 4.2 & CT 1 e CT 2 & 0,018 \\
\hline \multirow{3}{*}{$\begin{array}{c}\text { Córrego do Gregório } \\
\text { (CG) }\end{array}$} & 6.1 a 6.4 & CG 1 a CG 14 & 0,035 \\
\cline { 2 - 4 } & 6.4 a 6.5 & CG 15 a CG 21 & 0,025 \\
\cline { 2 - 4 } & 6.5 a 6.6 & CG 22 a CG 24 & 0,020 \\
\hline
\end{tabular}

As seções especificadas na Tabela 11, coluna 2, que determinam os trechos, podem ser observadas através da configuração da rede de macrodrenagem da cidade de São Carlos (ANEXO C) e as seções nos trechos de cada córrego e rio estão indicadas em planta de acordo com o exemplo da Figura 16.

De posse de todos estes parâmetros calculou-se o alfa e o beta através das equações 9 e 10, para os trechos especificados. Logo após, foi feita uma nova discretização do conjunto de sub-bacias para uso do modelo EESC, motivo pelo qual os arquivos de dados DREDAD, SUBDAD e TREDAD foram modificados. A discretização foi feita subdividindo em duas sub-bacias, as sub-bacias 41 e 49, devido ao tamanho delas.

A divisão das sub-bacias seguiu corretamente a delimitação de bacias hidrográficas, que inicia do ponto mais baixo, no caso o exutório, até o ponto mais alto, do divisor de água. A sub-bacia 41 se transformou em 41 e 42, e a sub-bacia 49 em 50 e 51. A configuração da rede de macrodrenagem da cidade de São Carlos, inicialmente composta por 54 sub-bacias e 7 tramos (ANEXO C) ficou definida após a nova discretização com 57 sub-bacias e 11 tramos (ANEXO D).

\section{5 Área de estudo}

O município de São Carlos está inserido em duas grandes bacias hidrográficas: Mongi-Guaçu e Tietê-Jacaré, fazendo parte de dois Comitês Estaduais de Bacias Hidrográficas. A maior parte da zona urbana está localizada na Bacia do Tietê-Jacaré, mas a ocupação de uso urbano tem se expandido em direção a Bacia do Mogi-Guaçu. 
Além disso, o município está localizado na zona de recarga do Aqüífero Guaraní, e já utiliza 40,6\% da água que consome de poços profundos localizados neste aqüífero e hidrografícamente, é subdivido em dez microbacias apresentadas na Figura 18 a seguir:

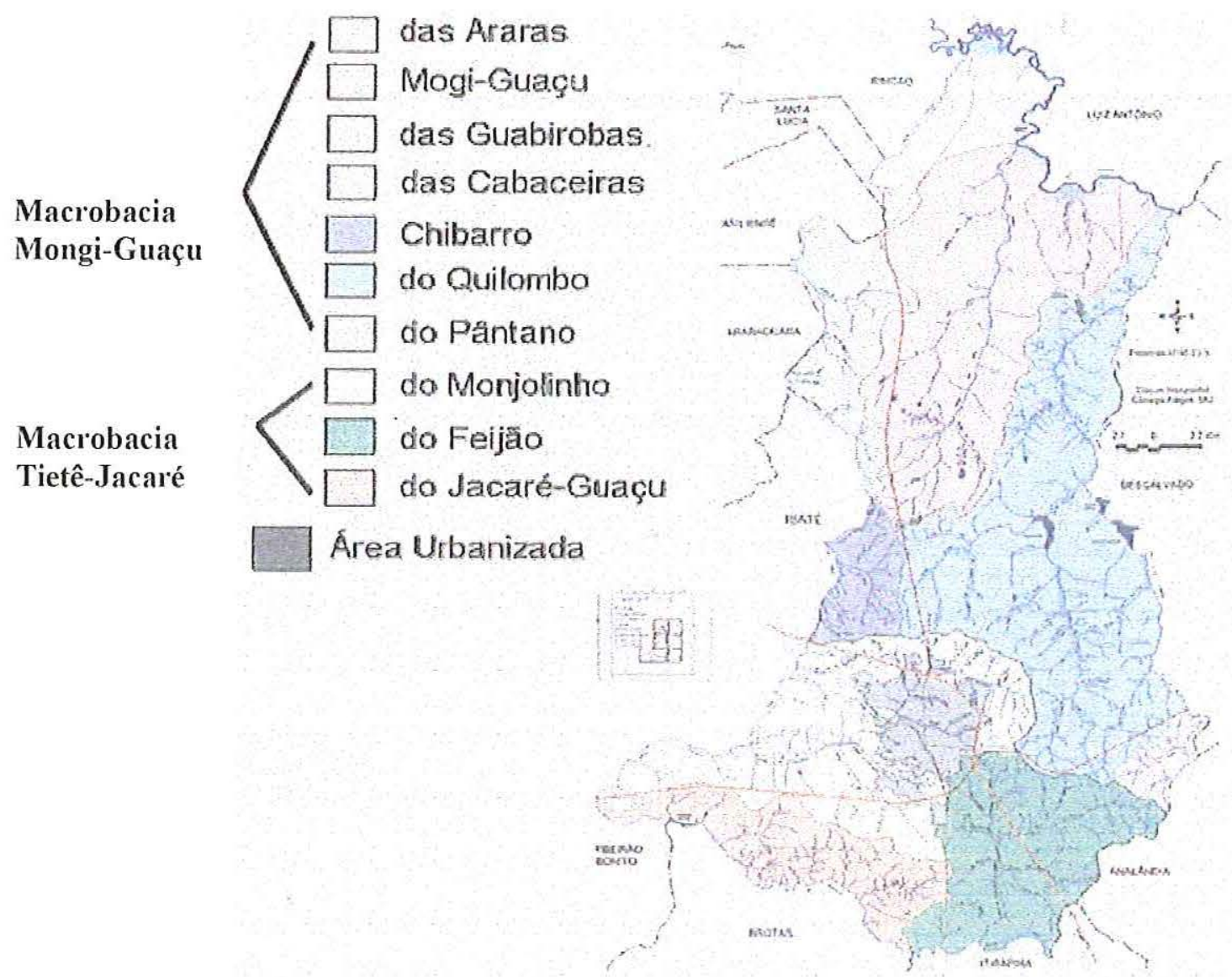

Figura 18 - Mapa do Município de São Carlos, com a especificação das microbacias hidrográficas.

Fonte: Relatório Pólis (2002, p.27).

A cidade de São Carlos foi escolhida para o estudo por apresentar graves inundações e as microbacias de maior relevância são: Microbacia do Monjolinho, a do Feijão e a do Quilombo. A escolhida para este estudo foi a Bacia do Monjolinho, pois é onde está localizada a área urbana da cidade, que está em processo progressivo de impermeabilização, gerando problemas de inundações em diversas áreas.

A Microbacia do Monjolinho é caracterizada por ser abastecedora de água do município e receptora do esgoto da cidade. Ela é responsável por fornecer um ponto 
importante de captação de abastecimento de água pelo Córrego do Espraiado. O Córrego do Monjolinho que dá nome a bacia, nasce na área urbana e possui um ponto de lançamento de parte do esgoto da cidade que é lançado in natura ao corpo d'água.

Para facilitar o estudo a Bacia do Monjolinho foi discretizada em 54 sub-bacias, como já dito anteriormente, e mostrado no ANEXO C. Pertencem a esta bacia os córregos do Gregório, Tijuco Preto e Mineirinho, que dão nome à bacia e servirão de estudo para reavaliar a influência do grau de impermeabilização das microbacias urbanas.

\subsubsection{Características gerais do município de São Carlos}

Para o desenvolvimento do estudo se fez necessário o levantamento de características municipais e urbanas, que interferem direta e indiretamente na operação, manutenção e implantação de sistema de drenagem urbana. Os aspectos são os seguintes:

- Demografia - população rural e urbana, taxas de crescimento, densidade populacional;

- Clima - precipitação pluviométrica e temperatura média;

- Legislação municipal relacionada com o sistema de drenagem urbana - lei de parcelamento do solo, lei de zoneamento, código de posturas e plano diretor;

- Limpeza pública - responsável, atividades, disposição de entulhos e varrição pública;

- Análise dos projetos do sistema de drenagem urbana - diretrizes para projetos de macrodrenagem; existência de cadastro da rede de micro e macrodrenagem; pontos de inundação e erosão; responsabilidade pela execução e manutenção do sistema de drenagem;

- Identificação de problemas do sistema de drenagem urbana.

As características gerais do município de São Carlos estão no CD-ROM, ANEXO B, no Relatório Pólis. 
A importância da caracterização das bacias hidrográficas urbanas fundamenta a avaliação dos parâmetros que condicionam a vazão. Isto porque se deve ter como princípio, durante o processo de urbanização e implantação do sistema de drenagem, a permanência das condições hidrológicas naturais da bacia.

O levantamento do meio físico pode ser desenvolvido caracterizando os seguintes aspectos: delimitação de bacias hidrográficas, topografia, pluviometria, temperatura, permeabilidade das diferentes camadas de solo, entre outros.

Para realizar esta caracterização foram utilizados os seguintes instrumentos:

- Mapas topográficos, na escala de 1:10.000;

- Fotos aéreas;

- Mapas de tipo de solo;

- Visita de campo.

A Bacia do Monjolinho está situada no município de São Carlos, São Paulo e apresenta uma ocupação predominantemente residencial, com algumas edificações unifamiliares. A Figura 19 apresenta a Bacia do Monjolinho, com a especificação da malha urbana do município de São Carlos e indicação dos córregos que serão reavaliados neste estudo.

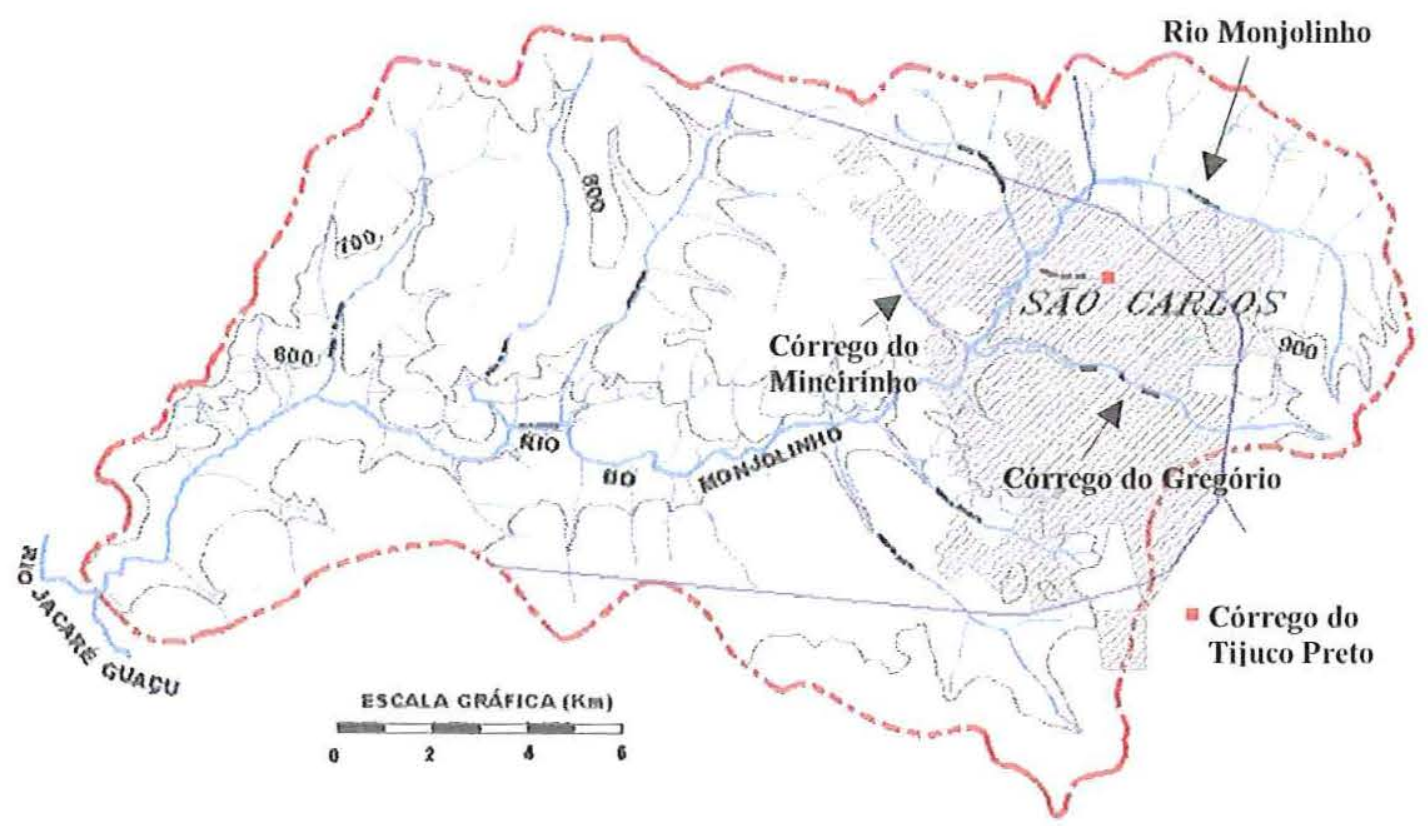

Figura 19 - Bacia do Monjolinho.

Fonte: CDCC (2002). 
O Córrego do Gregório é o afluente principal do Rio Monjolinho, pois é o córrego que atravessa a parte mais densa da cidade de São Carlos, e o que contribui para as cheias, em vista da crescente urbanização de sua bacia. A situação é bastante agravante neste córrego, principalmente na parte central da cidade, onde áreas residenciais e comerciais são as mais atingidas e prejudicadas. Através das Figuras 20, 21, 22 e 23 pode se ter uma noção da dimensão do problema de inundação que ocorre nesta área.

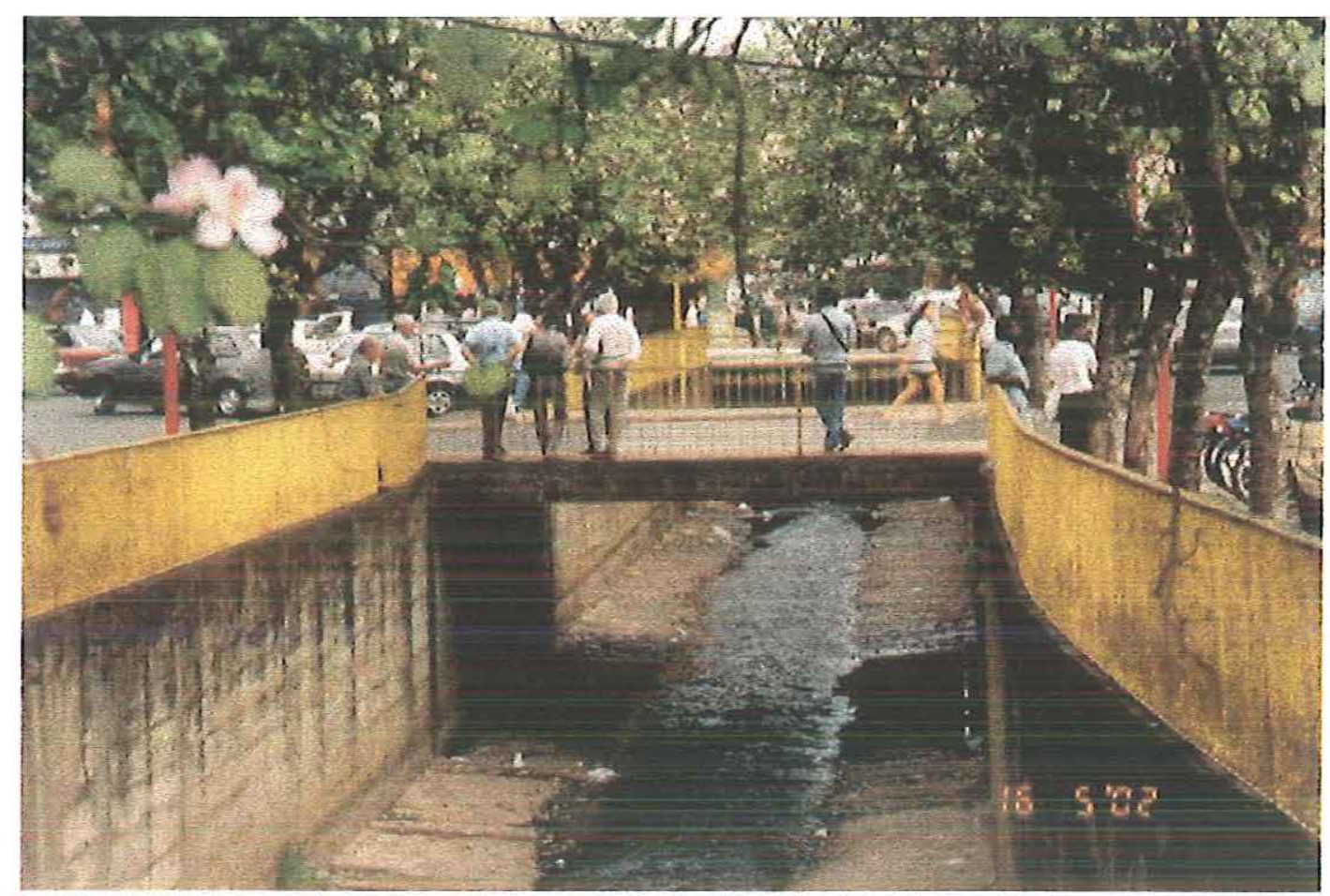

Figura 20 - Trecho canalizado do Córrego do Gregório, na região central de São Carlos.

Fonte: Prof. Dr. Eduardo Mario Mendiondo (SHS/EESC/USP, 2002). 


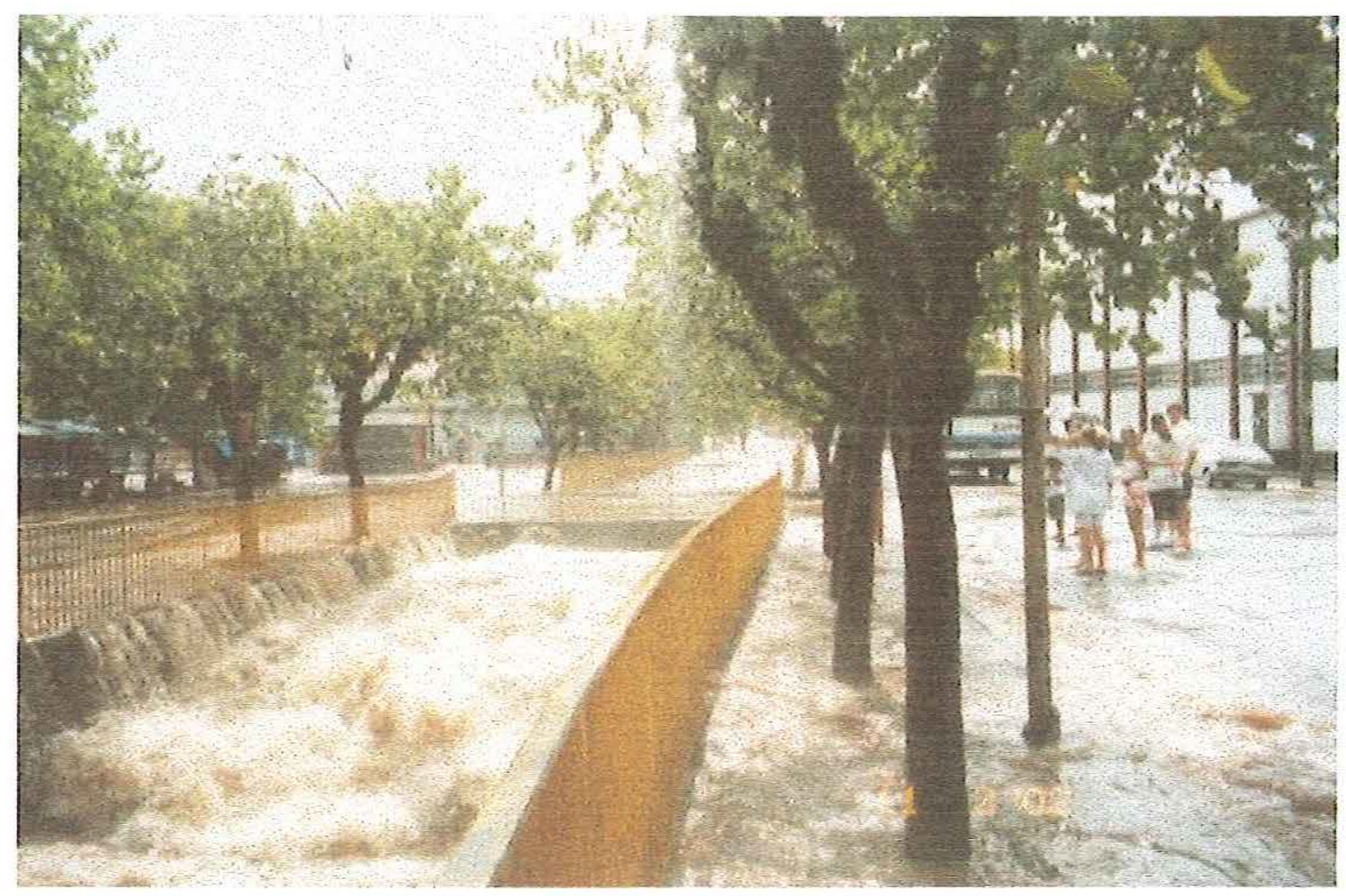

Figura 21 - Trecho do Córrego do Gregório, na região do Mercado Municipal, a mais atingida pelas enchentes.

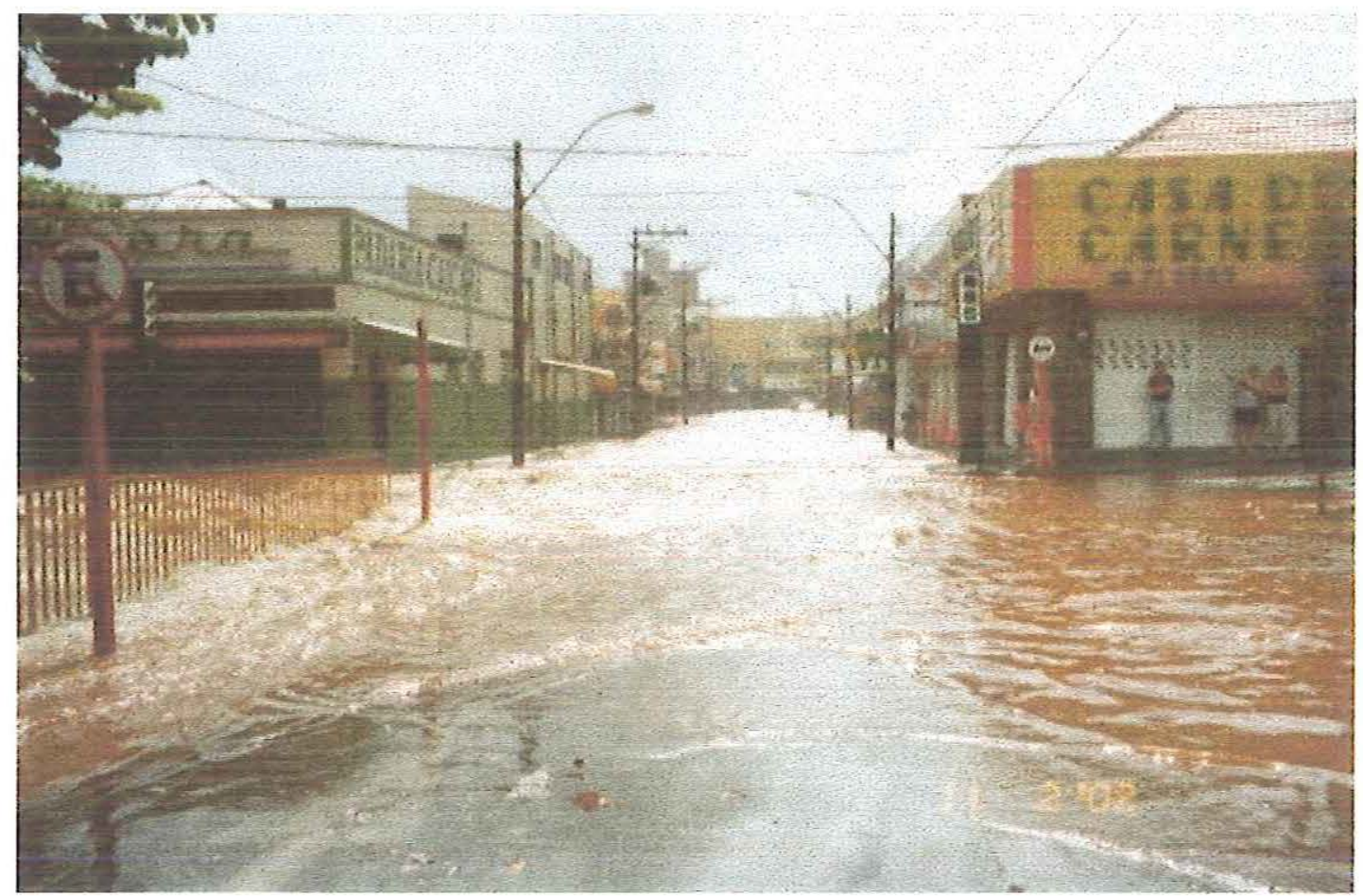

Figura 22 - Região central de São Carlos, onde as áreas comerciais (Padaria Caiçara) são mais atingidas pelas enchentes (Córrego do Gregório). 


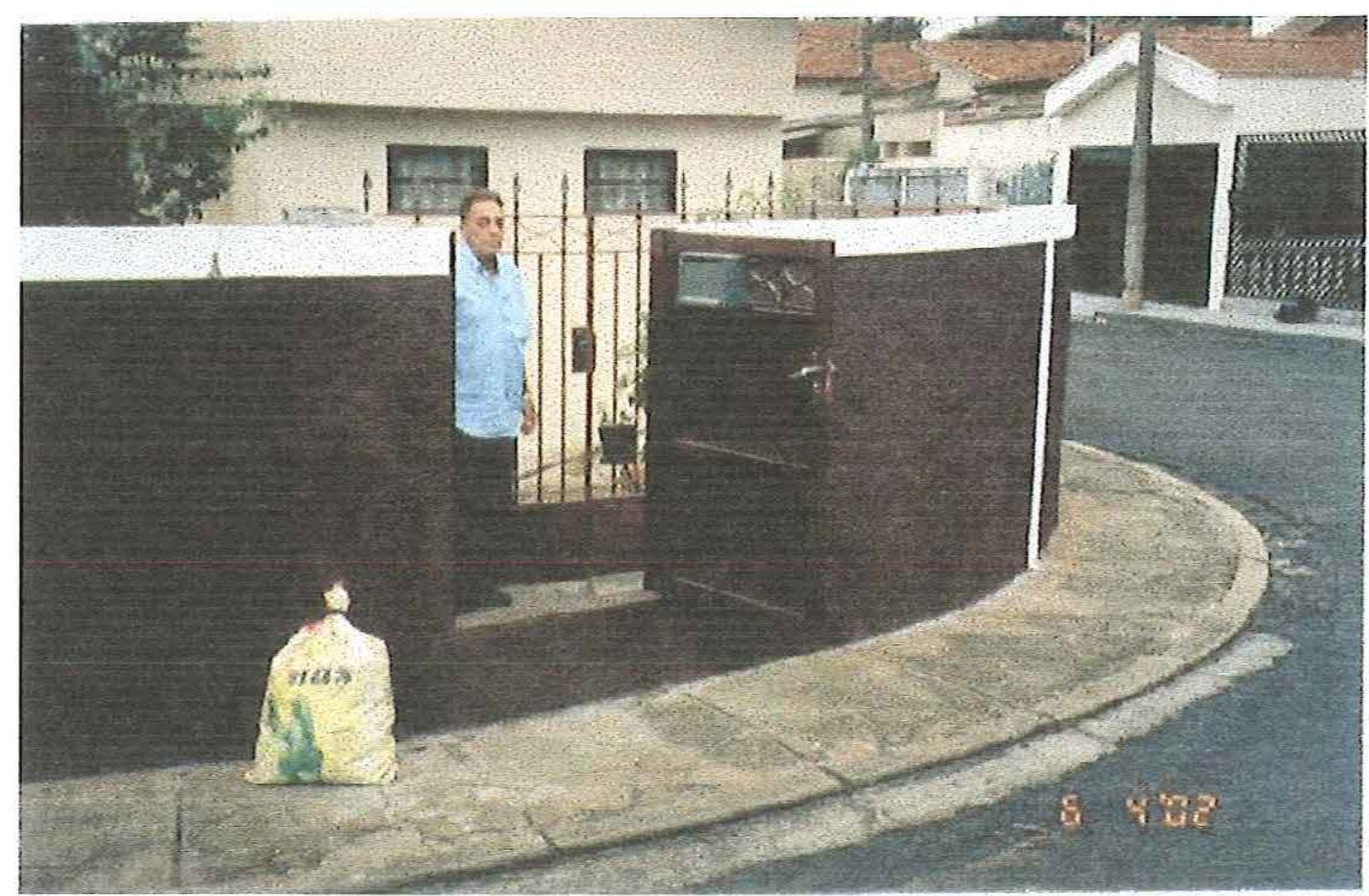

Figura 23 - Área residencial atingida pelas enchentes (proteção contra enchentes), localizada no bairro Lagoa Serena.

Fonte (Figuras 21, 22, 23): Pedro Caballero (Defesa Civil, 2002).

\subsubsection{Tipo de solo do município de São Carlos}

O município de São Carlos é caracterizado por solos de alta permeabilidade, sendo constituído, em sua maioria, por zonas de solo vermelho-amarelo e de areia quartzoza profunda, que possui característica arenosa. Identificam-se também grandes manchas de latossolo vermelho, amarelo e roxo, que são solos mais argilosos e pequena quantidade de terra roxa. Através da Figura 24 pode-se observar a pedologia do município de São Carlos.

As zonas de latossolo são as mais adequadas a expansão urbana comparadas às arenosas, por serem menos suscetíveis a erosão. A presença do Aqüifero Guaraní somada as áreas de alta permeabilidade encontradas no solo do município requer diretrizes específicas tanto para ocupação urbana como agropecuária evitando o agravamento do processo de contaminação do aqüífero citado. 


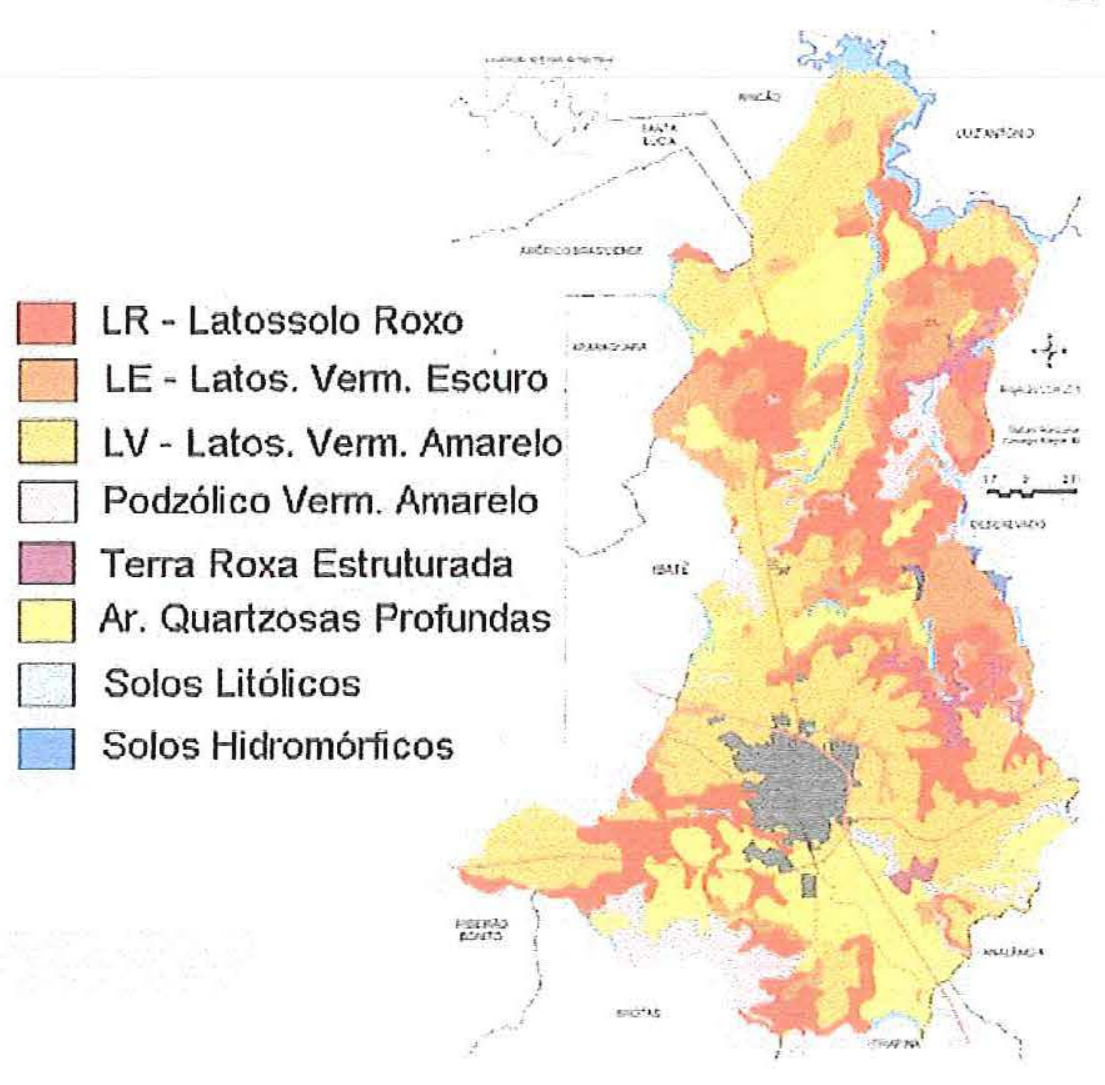

Figura 24 - Pedologia do município de São Carlos.

Fonte: Relatório Pólis (2002, p.29).

\subsubsection{Uso do solo urbano de São Carlos}

São Carlos é uma cidade basicamente horizontal, com baixo índice de densidade demográfica e predominância de uso misto. A diversidade de uso na malha urbana permite a proximidade de uso residencial, comercial, serviços e pequenas empresas, mas o excesso desta permissividade gera conflitos de uso e necessidade de controle urbanístico.

Por isso, a tendência de verticalização na área urbana central, induzida pela legislação urbanística em vigor, coloca em risco o patrimônio de interesse histórico e cultural que é bastante significativo para o município.

A lógica de ocupação do solo tem sido regulada pelo interesse do mercado imobiliário, não vinculada às condições de infra-estrutura, gerando problemas de 
mobilidade, moradia e degradação ambiental. A Figura 25 apresenta o uso do solo na área urbana da cidade de São Carlos.

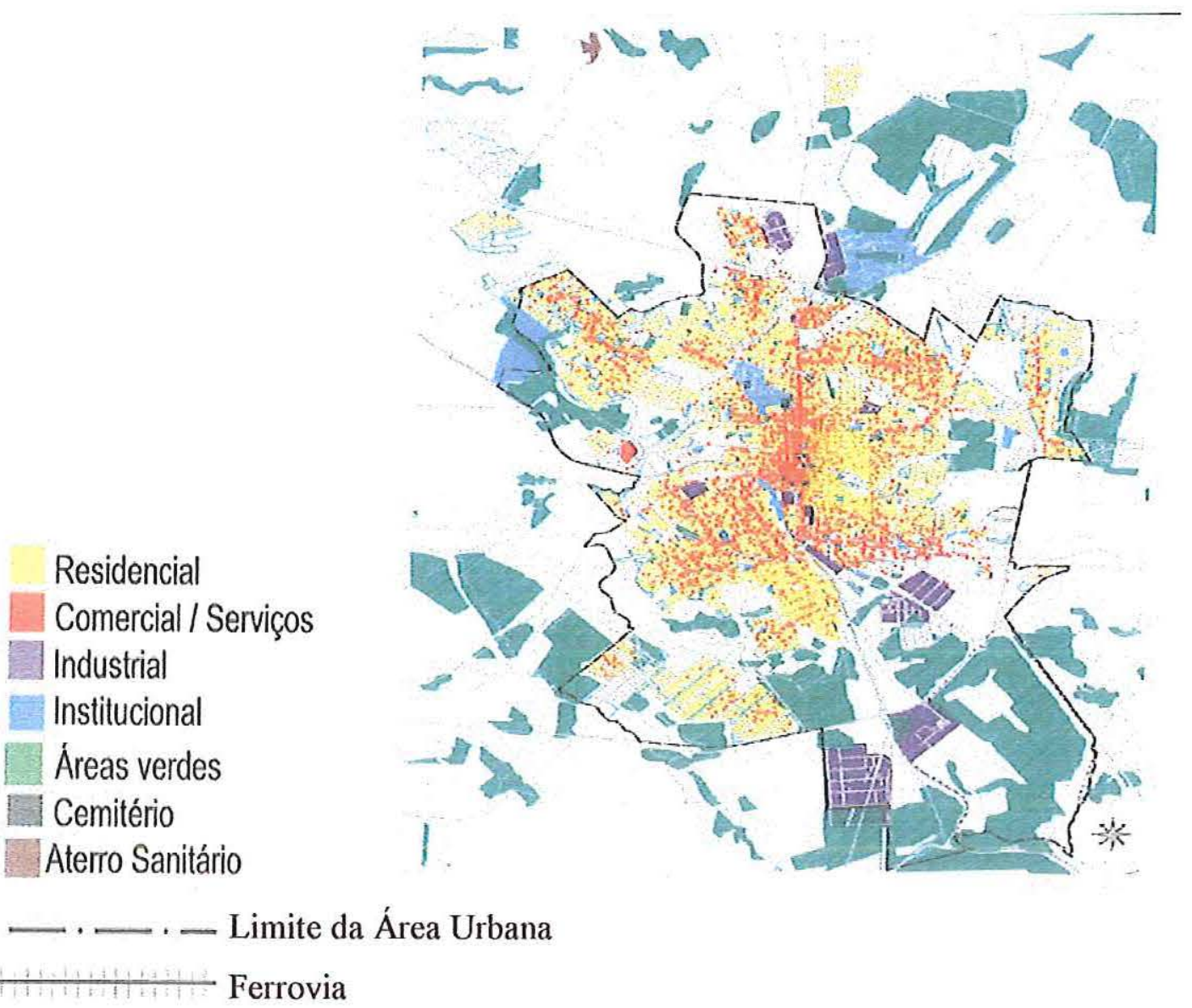

Figura 25 - Uso do solo na área urbana de São Carlos.

Fonte: Relatório Pólis (2002, p.62).

\subsubsection{Infra-estrutura do município de São Carlos}

De acordo com a Figura 26, que apresenta as condições de infra-estrutura da área urbana de São Carlos, as condições mais favoráveis de infra-estrutura localizam-se na área central da cidade, onde a drenagem é satisfatória e não existe problema no Sistema de Abastecimento de Água. A pior situação se encontra na direção sudoeste (no bairro Cidade Aracy), onde as áreas estão sujeitas à erosão, risco de interrupção de abastecimento de água e sistema de drenagem precário. 
Os problemas identificados são vários, um dos principais é o crescimento desordenado da cidade, que cresceu muito rapidamente e de forma injusta. Há também a questão dos loteamentos clandestinos, ou irregulares, que trazem bastante problema à cidade, porque os loteadores prometem uma boa condição de infra-estrutura e não cumprem, e os problemas acabam para ser resolvidos pelo poder público.
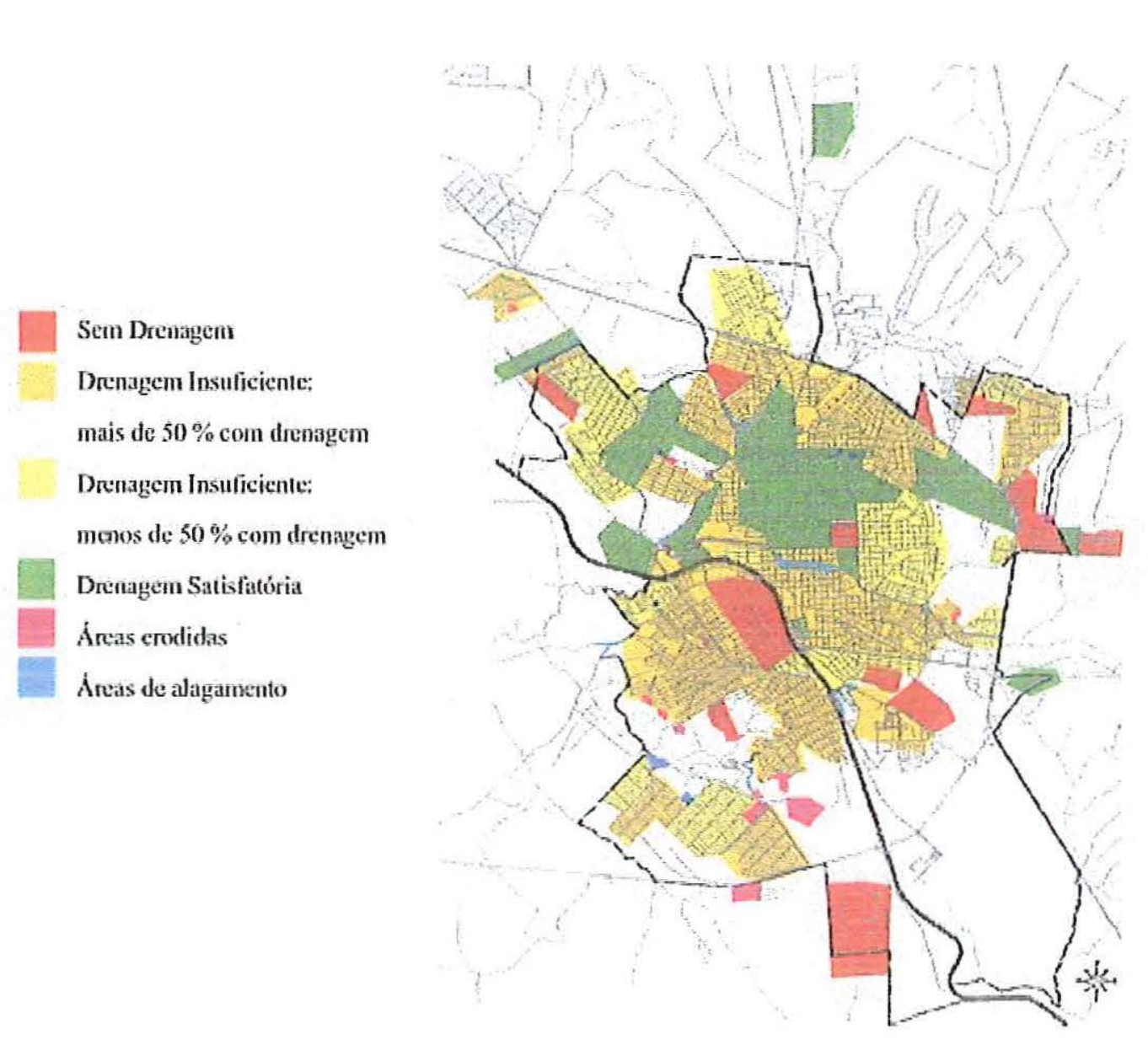

Figura 26 - Área urbana de São Carlos, com as condições de infra-estrutura da cidade.

Fonte: Relatório Pólis (2002, p.38).

Embora seja um pólo de alta tecnologia, a cidade tem $0 \%$ de esgoto tratado, com exceção ao campus da USP e precariedade de infra-estrutura concentrada em alguns locais. A área urbana apresenta conflitos de ocupação com o meio ambiente e os itens a seguir representam as condições em que se encontra: 
- Invasão de Áreas de Preservação Permanente (APPs) por ocupação urbana;

- $0 \%$ de tratamento de esgoto;

- Precariedade das redes de infra-estrutura;

- Necessidade de previsão de abastecimento de água;

- Comprometimento das bacias por vetores de ocupação urbana desordenada;

- Necessidade de novo Aterro Sanitário para disposição de entulhos. 


\section{RESULTADOS E DISCUSSÕES}

Neste capítulo são apresentados e analisados os resultados obtidos durante este período de desenvolvimento de pesquisa. O modelo EESC foi aplicado nas bacias do Tijuco Preto, Gregório e Mineirinho, que estão contidas na parte da Bacia do Monjolinho, da cidade de São Carlos - SP, discretizada para este estudo.

Os dados utilizados em cada arquivo de dados, em relação à rede de macrodrenagem de São Carlos (ANEXO C) descritos no item 4.3, foram inseridos no programa de pré-processamento do modelo. A partir de então, os arquivos com os dados de entrada do modelo EESC foram utilizados no programa principal, responsável pela simulação dos hidrogramas.

\subsection{Discretização da Bacia do Monjolinho}

No ANEXO C são apresentadas as sub-bacias inicialmente discretizadas (total de 54), na qual a parte da Bacia do Monjolinho considerada neste trabalho foi subdividida e sua macrodrenagem foi discretizada em 7 tramos com 35 seções. Na subdivisão estão determinadas as bacias referentes aos córregos do Tijuco Preto, Gregório e Mineirinho, que são afluentes do Rio Monjolinho. Neste caso, os córregos dão nome às bacias incluídas no estudo, representadas por: Bacia do Tijuco Preto, Bacia do Gregório e Bacia do Mineirinho.

A discretização inicial do modelo apresentava duas sub-bacias com áreas muito grandes em relação às outras e ao estudo, por isso resolveu-se dividi-las em duas totalizando 56 sub-bacias, mas foi necessário para a nova discretização criar uma subbacia de área zero, pois a configuração da rede de macrodrenagem de São Carlos ficaria melhor representada. Então, a nova discretização (ANEXO D) ficou representada por 57 
sub-bacias, 11 tramos e 42 seções.

5.2 Alterações dos parâmetros

Devido a nova discretização houve modificações em alguns arquivos de dados como mencionadas no item 4.4, e estas modificações iniciaram com os parâmetros $\alpha$ e $\beta$, que são variáveis pertencentes ao arquivo de dados TREDAD, utilizados no cálculo da propagação ao longo de cada trecho. Eles foram obtidos a partir de seções determinadas em um mapa que continha a discretização inicial da bacia, totalizando 72 seções distribuídas em 13 trechos. A Tabela 12 apresenta os tramos e os trechos referentes a alguns córregos com a quantidade de seções por trecho e o nome dado a cada seção.

Tabela 12 - Número de seções por trecho em relação ao rio/córrego.

\begin{tabular}{|c|c|c|c|c|}
\hline Local & Tramo & Trecho & $N^{\circ}$ de Seções & Nome das Seções \\
\hline \multirow{7}{*}{$\begin{array}{l}\text { Rio } \\
\text { Monjolinho } \\
\text { (RM) }\end{array}$} & 1 & 13 & 9 & $\begin{array}{c}\text { (RM1, RM2, RM3, RM4, RM5, } \\
\text { RM6, RM7, RM8, RM9) }\end{array}$ \\
\hline & 1 & 14 & 15 & $\begin{array}{l}\text { (RM10, RM12, RM13, RM14, } \\
\text { RM15, RM16, RM17, RM18, } \\
\text { RM19, RM20, RM21, RM22, } \\
\text { RM 23, RM24) }\end{array}$ \\
\hline & 3 & 2 & 4 & (RM25, RM26, RM27, RM28) \\
\hline & 5 & 2 & 3 & (RM29, RM30, RM31) \\
\hline & 5 & 3 & 3 & (RM32, RM33, RM34) \\
\hline & 5 & 4 & 6 & $\begin{array}{c}\text { (RM35, RM36, RM37, RM38, } \\
\text { RM39, RM40) }\end{array}$ \\
\hline & 7 & 2 & 4 & (RM41, RM42, RM44) \\
\hline $\begin{array}{l}\text { Córrego do } \\
\text { Tijuco Preto } \\
\text { (TP) }\end{array}$ & 4 & 2 & 2 & $(\mathrm{CT} 1, \mathrm{CT} 2)$ \\
\hline \multirow{5}{*}{$\begin{array}{l}\text { Córrego do } \\
\text { Gregório } \\
\text { (CG) }\end{array}$} & 6 & 3 & 2 & (CG1, CG2) \\
\hline & 6 & 4 & 12 & $\begin{array}{l}\text { (CG3, CG4, CG5, CG6, CG7, } \\
\text { CG8, CG9, CG10, CG11, } \\
\text { CG12, CG13, CG14) }\end{array}$ \\
\hline & 6 & 5 & 7 & $\begin{array}{l}\text { (CG15, CG16, CG17, CG18, } \\
\text { CG19, CG20, CG21) }\end{array}$ \\
\hline & 6 & 6 & 3 & (CG22, CG23, CG24) \\
\hline & 6 & 7 & 2 & (CG25, CG26) \\
\hline
\end{tabular}


Os valores de $\alpha$ e $\beta$ determinados para cada trecho de toda a rede de macrodrenagem de São Carlos estão apresentados na Tabela 13. Os $\alpha$ e $\beta$ encontrados para as 72 seções representadas no mapa que estão contidas no relatório, onde os perfis de cada seção estão descritos em papel milimetrado, foram tranferidos para o AutoCAD 2002 e estão especificados em negrito com relação aos trechos citados na Tabela 12, e os valores de $\alpha$ e $\beta$ estimados na Tabela 13, que não estão em negrito, foram retirados do Seminário apresentado por Righetto e Porto (1994).

Tabela 13 - Valores de $\alpha$ e $\beta$ de toda a rede de macrodrenagem de São Carlos.

\begin{tabular}{|c|c|c|c|c|}
\hline Rio/Córrego & Tramo & Trecho & $\alpha$ & $\beta$ \\
\hline \multirow{13}{*}{ Monjolinho } & 1 & 2 & 2,00 & 0,70 \\
\hline & 1 & 3 & 2,00 & 0,70 \\
\hline & 1 & 4 & 2,00 & 0,70 \\
\hline & 1 & 5 & 2,00 & 0,70 \\
\hline & 1 & 6 & 2,00 & 0,70 \\
\hline & 1 & 7 & 2,00 & 0,70 \\
\hline & 1 & 8 & 2,00 & 0,70 \\
\hline & 1 & 9 & 2,00 & 0,70 \\
\hline & 1 & 10 & 2,00 & 0,70 \\
\hline & 1 & 11 & 2,00 & 0,70 \\
\hline & 1 & 12 & 2,00 & 0,70 \\
\hline & 1 & 13 & 0,85 & 0,69 \\
\hline & 1 & 14 & 1,06 & 0,69 \\
\hline \multirow{3}{*}{$\begin{array}{c}\text { Santa Maria } \\
\text { Madalena }\end{array}$} & 2 & 2 & 2,00 & 0,70 \\
\hline & 2 & 3 & 2,00 & 0,70 \\
\hline & 2 & 4 & 2,00 & 0,70 \\
\hline Monjolinho & 3 & 2 & 1,31 & 0,66 \\
\hline Tijuco Preto & 4 & 2 & 0,43 & 0,73 \\
\hline \multirow{3}{*}{ Monjolinho } & 5 & 2 & 0,63 & 0,68 \\
\hline & 5 & 3 & 1,06 & 0,69 \\
\hline & 5 & 4 & 0,97 & 0,69 \\
\hline \multirow{6}{*}{ Gregório } & 6 & 2 & 1,00 & 0,70 \\
\hline & 6 & 3 & 0,59 & 0,79 \\
\hline & 6 & 4 & 0,80 & 0,78 \\
\hline & 6 & 5 & 0,61 & 0,75 \\
\hline & 6 & 6 & 0,78 & 0,71 \\
\hline & 6 & 7 & 0,81 & 0,71 \\
\hline Monjolinho & 7 & 2 & 1,15 & 0,70 \\
\hline
\end{tabular}


A partir da divisão das duas sub-bacias que foram as sub-bacias 41 e 49 e a criação de uma sub-bacia de área zero, ocasionaram algumas modificações nos valores dos arquivos DREDAD, SUBDAD e TREDAD. Com o aumento do número de subbacias, tramos e conseqüentemente de seções, houve modificações no arquivo DREDAD, que possui a configuração da rede de macrodrenagem.

No arquivo SUBDAD inseriu as sub-bacias criadas com as respectivas variáveis utilizadas para a leitura deste arquivo, que se obteve com a utilização do planímetro e curvímetro para o cálculo da área de drenagem da sub-bacia, do comprimento do percurso principal do escoamento na sub-bacia e da declividade média do talvegue da sub-bacia. A Tabela 14 especifica os valores determinados das variáveis utilizadas no arquivo SUBDAD para as sub-bacias criadas.

Tabela 14 - Valores das variáveis utilizadas no arquivo SUBDAD para as sub-bacias criadas (Nova discretização das sub-bacias 41 e 49).

\begin{tabular}{|c|c|c|c|c|c|}
\hline $\begin{array}{c}\mathbf{N}^{\mathbf{0}} \mathbf{d a} \\
\text { Sub- } \\
\text { bacia }\end{array}$ & $\begin{array}{c}\text { Número de } \\
\text { Deflúvio (N) }\end{array}$ & $\begin{array}{c}\text { Comprimento } \\
\text { do Curso } \\
\text { Principal } \\
\text { (L) }\end{array}$ & $\begin{array}{c}\text { Grau de } \\
\text { Cobertura } \\
\text { Vegetal } \\
\text { (PP) }\end{array}$ & $\begin{array}{c}\text { Declividade } \\
\text { Média do } \\
\text { Talvegue } \\
\text { (S) }\end{array}$ & $\begin{array}{c}\text { Área de } \\
\text { Drenagem } \\
\text { (A) }\end{array}$ \\
\hline $\mathbf{4 1}$ & 75 & 2,32 & 0,50 & 0,02763 & 3,244 \\
\hline $\mathbf{4 2}$ & 75 & 2,10 & 0,50 & 0,01718 & 2,194 \\
\hline $\mathbf{5 0}$ & 90 & 0,83 & 0,25 & 0,07542 & 0,781 \\
\hline $\mathbf{5 1}$ & 90 & 1,47 & 0,25 & 0,02072 & 0,851 \\
\hline
\end{tabular}

Devido ao aumento do número de tramos da rede de canais e portanto do número de trechos, o arquivo TREDAD que contém os dados dos trechos da rede de canais, teve alguns valores das variáveis modificados devido à nova discretização, além disso, os novos valores de $\alpha$ e $\beta$ especificados em negrito na Tabela 13, foram substituídos pelos valores iniciais.

\subsection{Simulações}

O Modelo Hidrológico pode ser testado para toda a rede de macrodrenagem da cidade de São Carlos (ANEXO C), mas precauções devem ser tomadas quanto aos resultados obtidos das simulações, uma vez que, alguns parâmetros hidráulicos e

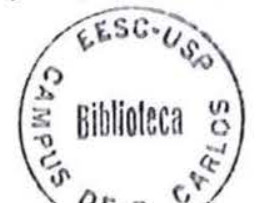


hidrológicos das sub-bacias e dos canais ainda não estão devidamente ajustados.

O resultado de qualquer simulação é armazenado no momento em que solicita no monitor o nome de um arquivo, neste arquivo, encontra-se o hidrograma gerado de uma sub-bacia ou seção de extremidade de jusante de um determinado tramo da rede de canais principais.

A apresentação do hidrograma de cheia gerado após a simulação para a comparação dos três métodos já mencionados, foi feita como mostrado na Figura 27, onde se adotou para o período de retorno (TR), 10 anos e para duração da chuva (DC), 1 hora. Os valores obtidos das vazões de pico em um determinado tempo, em relação a cada método, está citado na Tabela 15 e os arquivos de dados usados como entrada do modelo para gerar os hidrogramas, não tiveram nenhuma alteração.

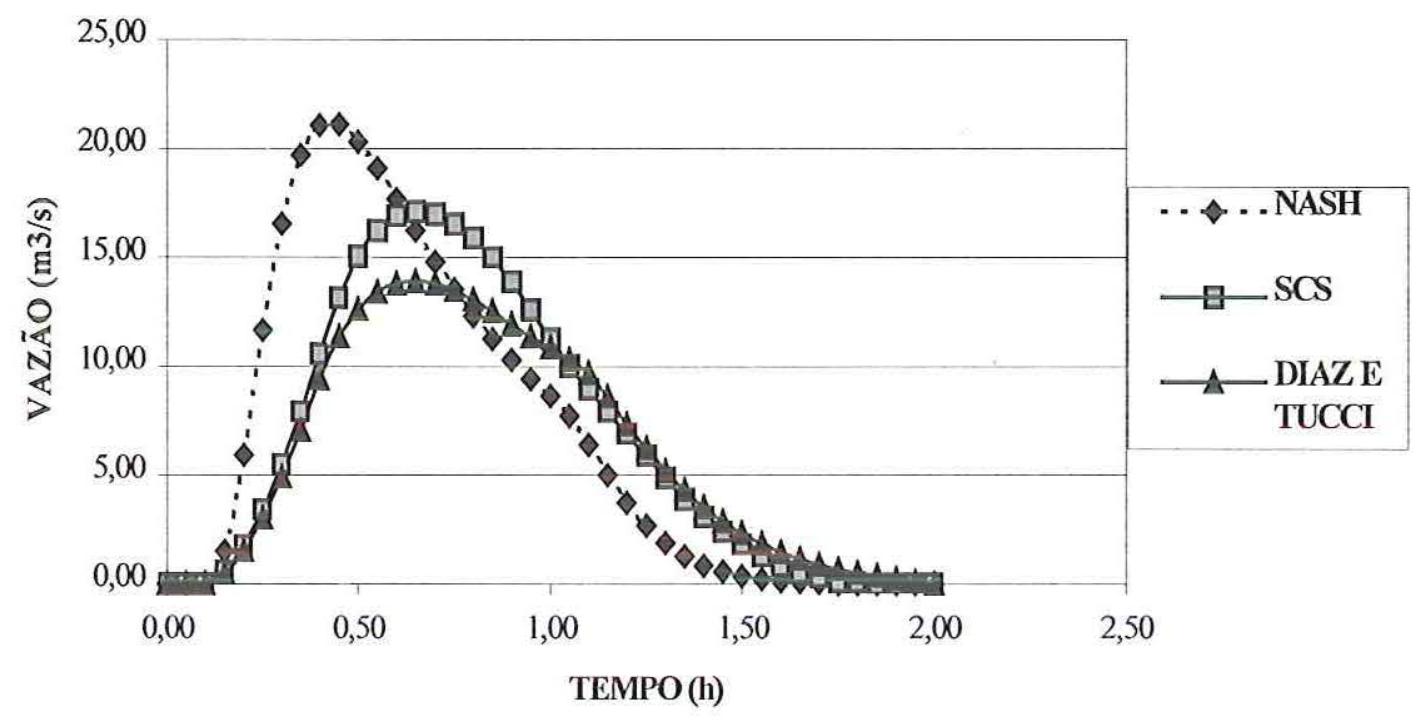

Figura 27 - Hidrogramas de cheia da sub-bacia 35, que representa a área de montante da Bacia do Tijuco Preto.

Tabela 15 - Valores das vazões de pico para os três métodos com o referente tempo, sub-bacia 35.

\begin{tabular}{|c|c|c|}
\hline \multirow{2}{*}{ Método } & \multicolumn{2}{|c|}{ Figura 27 } \\
\cline { 2 - 3 } & $\begin{array}{c}\text { Vazão de Pico } \\
\left(\mathrm{m}^{3} / \mathbf{s}\right)\end{array}$ & $\begin{array}{c}\text { Tempo } \\
\text { (h) }\end{array}$ \\
\hline NASH & 21,09 & 0,45 \\
\hline SCS & 17,11 & 0,65 \\
\hline DIAZ E TUCCI & 13,89 & 0,65 \\
\hline
\end{tabular}


A partir da simulação apresentada foram feitas outras simulações para comparação dos três métodos, antes (ANEXO C) e após a nova discretização (ANEXO D), com o mesmo TR e DC, para analisar a interferência obtida nos hidrogramas. Para isso, simulou-se hidrogramas em sub-bacias e seções, principalmente nas sub-bacias 41 e 49 que foram modificadas e no exutório da parte da Bacia do Monjolinho considerada neste estudo.

Além do mais, analisou-se a influência nos hidrogramas com o aumento do número de deflúvio $(\mathrm{N})$ e a diminuição do grau de vegetação $(\mathrm{PP})$, aumentando a área de impermeabilização, tornando-a mais urbanizada. A seguir, será apresentada a análise da comparação dos três métodos através dos hidrogramas de cheia, apresentados graficamente sem modificações (discretização inicial) e com modificações (nova discretização).

Comparação da Sub-bacia 41 (discretização inicial) com a seção 6.2 (nova discretização) 


\section{Sub-bacia 41}

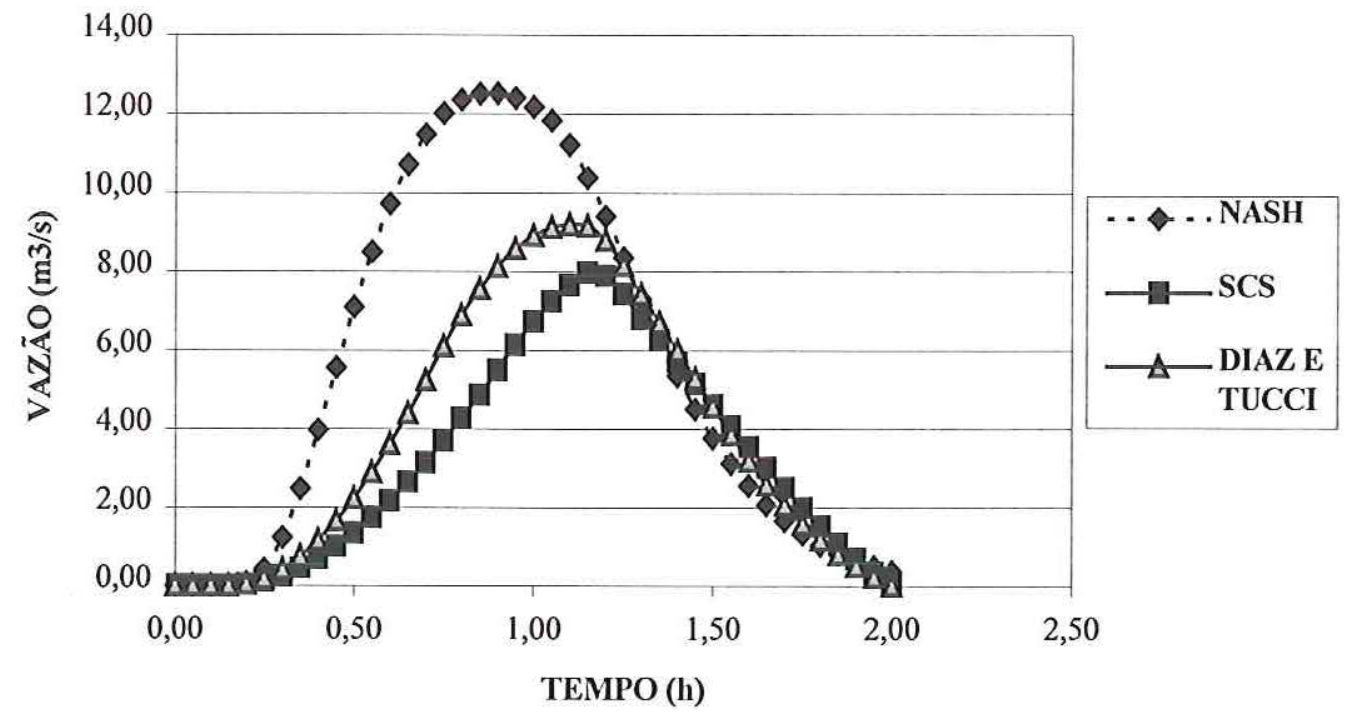

Figura 28 - Hidrogramas de cheia da sub-bacia 41, sem modificações.

\section{Seção 6.2}

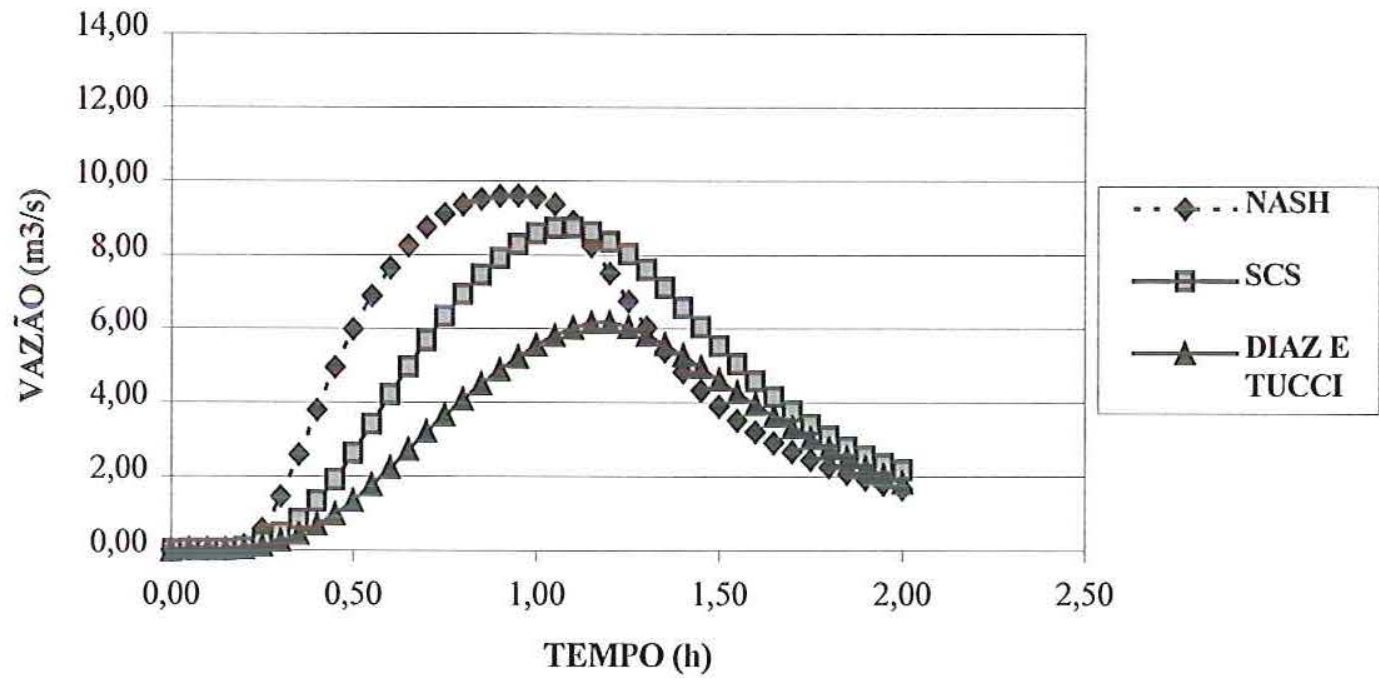

Figura 29 - Hidrogramas de cheia da seção 6.2, com modificações.

$\mathrm{Na}$ análise feita entre as Figuras 28 e 29, verificou-se que a nova discretização da sub-bacia 41 e as modificações nos arquivos de dados do modelo EESC, interferiram nos hidrogramas de cheia. Comparando a Figura 28 que representa os hidrogramas da sub-bacia 41, sem modificações nos arquivos de dados, com a Figura 29 que apresenta os hidrogramas da seção 6.2, com modificações nos arquivos de dados, as vazões de 
pico estão mais elevadas nos hidrogramas da Figura 28, além disso, o método de Nash e o de Diaz e Tucci antecederam os seus picos.

Comparando método a método as duas figuras, o método de Nash foi o que mais decaiu a vazão de pico em relação aos outros dois métodos, após a nova discretização. A Tabela 16 mostra claramente que o método de Nash foi o mais afetado na simulação do hidrograma de cheia, pois sua vazão máxima decaiu de $12,52 \mathrm{~m}^{3} / \mathrm{s}$ para $9,60 \mathrm{~m}^{3} / \mathrm{s}$ praticamente no mesmo tempo.

Tabela 16 - Valores da vazão de pico para os três métodos com o referente tempo, subbacia 41 e seção 6.2 .

\begin{tabular}{|c|c|c|c|c|}
\hline \multirow{2}{*}{ Método } & \multicolumn{2}{|c|}{$\begin{array}{c}\text { Figura 28 } \\
\text { (sem modificações) }\end{array}$} & \multicolumn{2}{c|}{$\begin{array}{c}\text { Figura 29 } \\
\text { (com modificações) }\end{array}$} \\
\cline { 2 - 5 } & $\begin{array}{c}\text { Vazão de Pico } \\
\left(\mathbf{m}^{\mathbf{3}} / \mathbf{s}\right)\end{array}$ & $\begin{array}{c}\text { Tempo } \\
\text { (h) }\end{array}$ & $\begin{array}{c}\text { Vazão de Pico } \\
\left(\mathbf{m}^{\mathbf{3}} / \mathbf{s}\right)\end{array}$ & $\begin{array}{c}\text { Tempo } \\
\text { (h) }\end{array}$ \\
\hline NASH & 12,52 & 0,90 & 9,60 & 0,95 \\
\hline SCS & 9,20 & 1,10 & 8,73 & 1,10 \\
\hline DIAZ E TUCCI & 7,98 & 1,15 & 6,16 & 1,20 \\
\hline
\end{tabular}

Isso ocorreu devido ao estudo que Nash fez, usando como referência particular as Bacias Hidrográficas Inglesas, e os parâmetros da distribuição n, k utilizados no método de Nash, estão relacionados com as características fisiográficas da bacia, como segue:

$$
\begin{aligned}
& n=\frac{L^{0.1}}{0.43} \\
& K=\frac{8.921 A^{0.3}}{\left(I^{0.3} L^{0.1}\right)}
\end{aligned}
$$

onde, L $(\mathrm{km})$ é o comprimento do curso d'água principal, $\mathrm{A}\left(\mathrm{km}^{2}\right)$ a área da bacia e I (1/10000) a declividade média do talvegue. Estes parâmetros " $n$ " e " $k$ " demonstraram ser bastante sensíveis com a nova discretização, por isso houve esta discrepância no método de Nash em relação aos outros dois métodos.

\section{Comparação da Sub-bacia 49 (discretização inicial) com a seção 8.2 (nova discretização)}




\section{Sub-bacia 49}

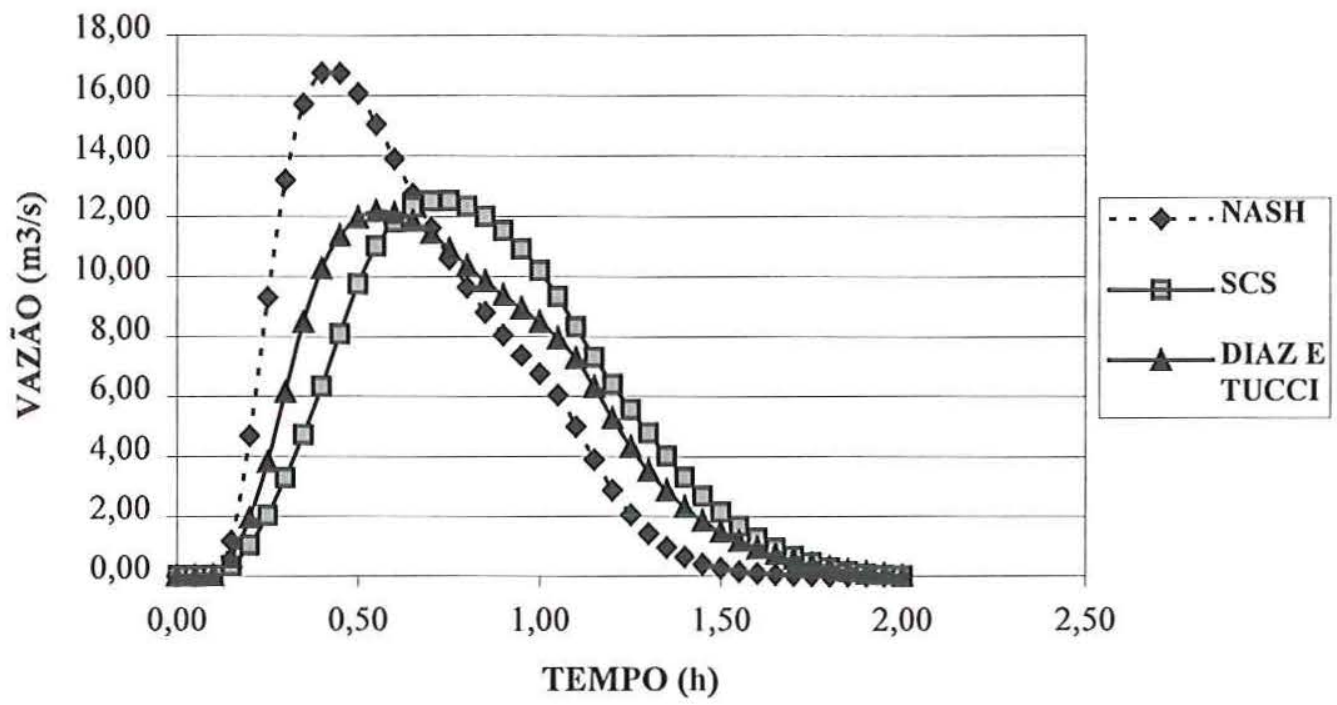

Figura 30 - Hidrogramas de cheia da sub-bacia 49, sem modificações.

\section{Seção 8.2}

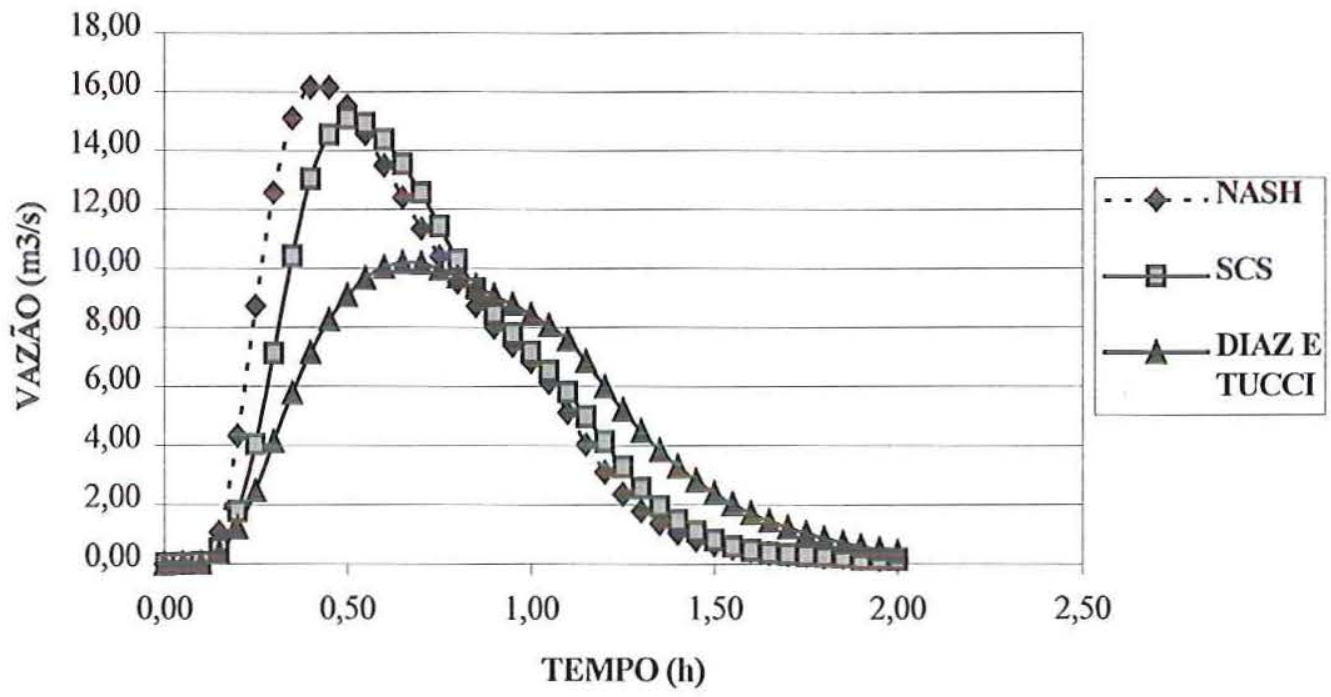

Figura 31 - Hidrogramas de cheia da seção 8.2, com modificações.

As Figuras 30 e 31 que representam os hidrogramas de cheia pelos três métodos na sub-bacia 49, antes da discretização e na seção 8.2, após a discretização, foram analisadas e comparadas, método a método, para se obter a interferência nos hidrogramas após a nova discretização. Comparando os três métodos, observa-se que a vazão de pico está oscilando para mais e para menos em relação às duas figuras. 
Observou-se que com a nova discretização das sub-bacias e conseqüentemente a criação de novas áreas, o hidrograma de cheia após a nova simulação modificou bastante, pois como se pode observar na Tabela 17, a vazão de pico pelo método de Nash e de Diaz e Tucci decaiu, já pelo método do SCS se elevou significantemente.

Tabela 17 - Valores da vazão de pico associado ao tempo para os três métodos, subbacia 49 e seção 8.2 .

\begin{tabular}{|c|c|c|c|c|}
\hline \multirow{2}{*}{ Método } & \multicolumn{2}{|c|}{$\begin{array}{c}\text { Figura 30 } \\
\text { (sem modificações) }\end{array}$} & \multicolumn{2}{c|}{$\begin{array}{c}\text { Figura 31 } \\
\text { (com modificações) }\end{array}$} \\
\cline { 2 - 5 } & $\begin{array}{c}\text { Vazão de Pico } \\
\left(\mathbf{m}^{3} / \mathbf{s}\right)\end{array}$ & $\begin{array}{c}\text { Tempo } \\
\text { (h) }\end{array}$ & $\begin{array}{c}\text { Vazão de Pico } \\
\left(\mathbf{m}^{3} / \mathbf{s}\right)\end{array}$ & $\begin{array}{c}\text { Tempo } \\
\text { (h) }\end{array}$ \\
\hline NASH & 16,76 & 0,40 & 16,15 & 0,40 \\
\hline SCS & 12,51 & 0,75 & 15,08 & 0,50 \\
\hline DIAZ E TUCCI & 12,16 & 0,55 & 10,18 & 0,65 \\
\hline
\end{tabular}

Esta análise obtida através das Figuras 28, 29, 30 e 31 serviu para observar a sensibilidade dos três métodos na influência dos hidrogramas, com a nova discretização realizada na rede de macrodrenagem de São Carlos. Como conclusão da comparação entre os métodos em cada figura, pode-se ressaltar que o método de Nash está sempre superdimensionado em relação aos outros dois.

Comparação da Seção 7.2 (discretização inicial) com a seção 11.2 (nova discretização) 
Seção 7.2

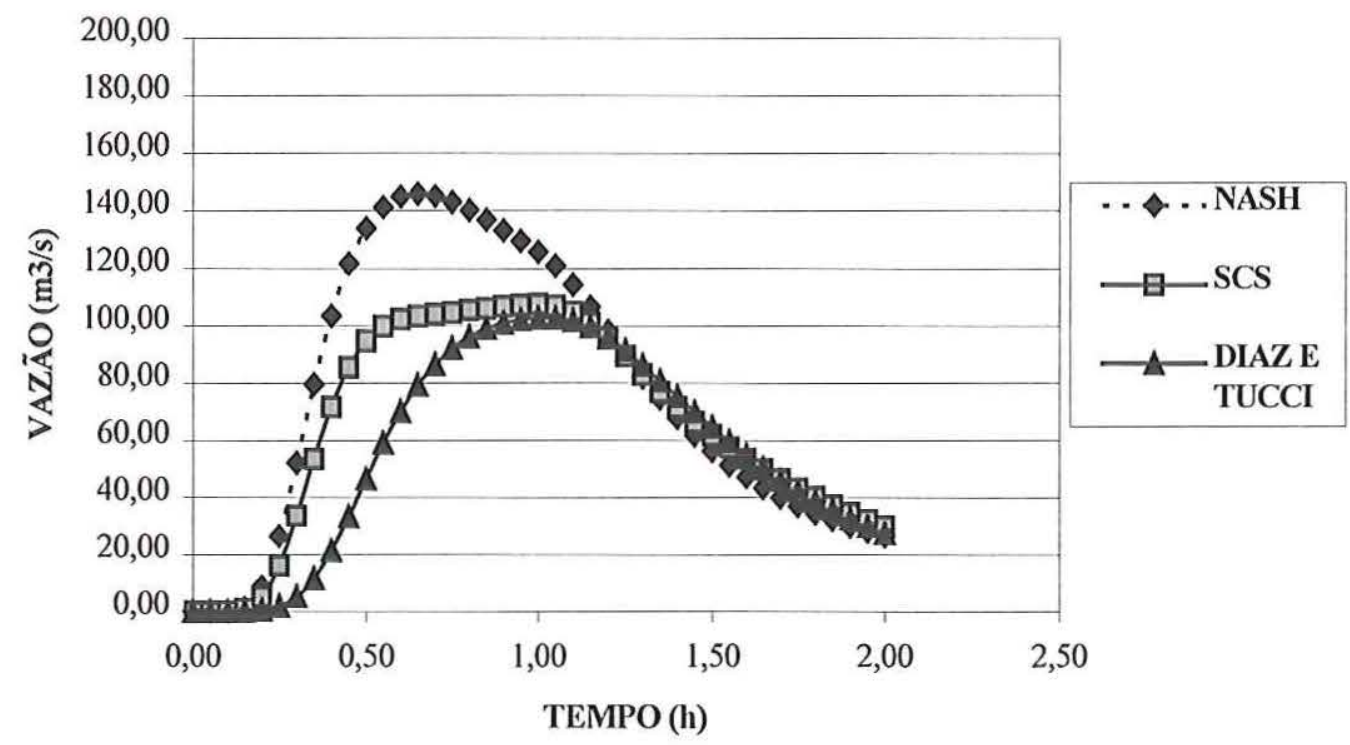

Figura 32 - Hidrogramas de cheia da seção 7.2, sem modificações.

\section{Seção 11.2}

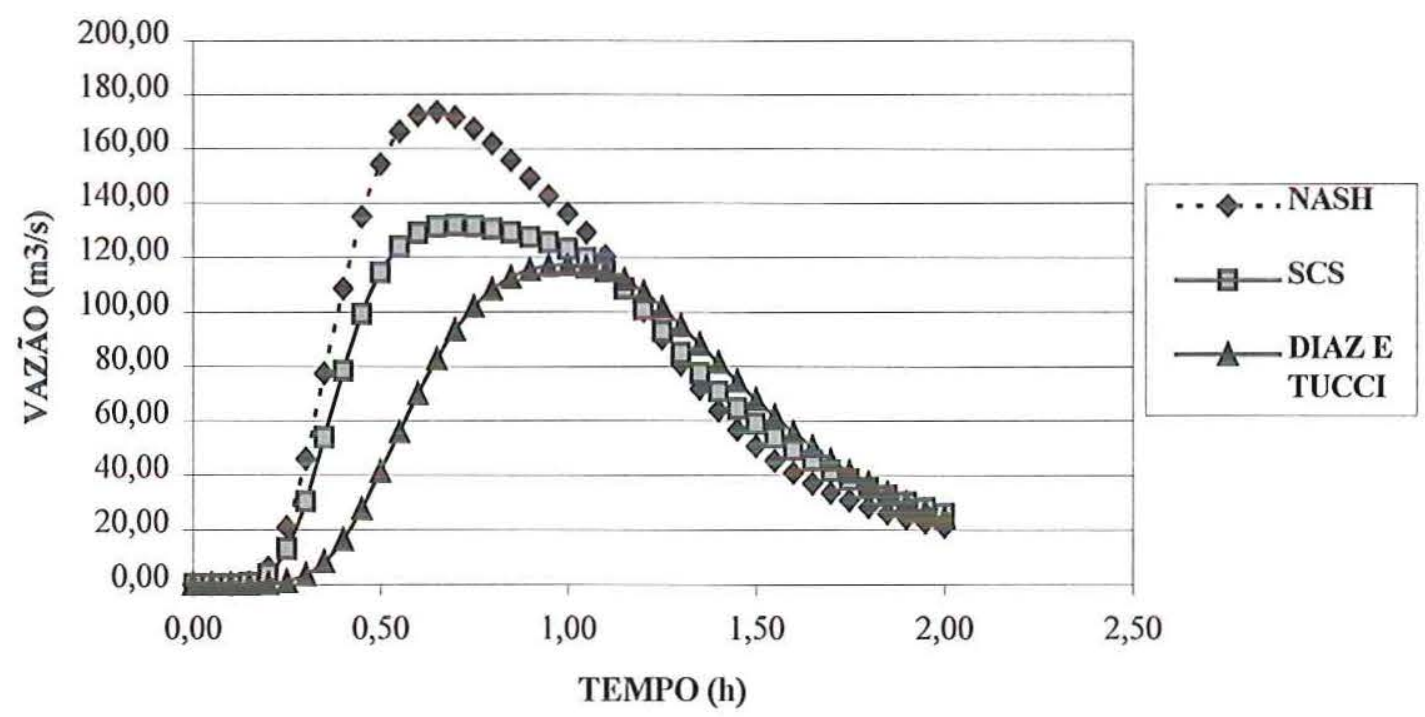

Figura 33 - Hidrogramas de cheia da seção 11.2, com modificações.

Os hidrogramas de cheia que estão representados pelas Figuras 32 e 33 na seção 7.2, com a discretização inicial e na seção 11.2, após a nova discretização, foram analisados e comparados, para se obter a influência na vazão de pico no exutório da Bacia do Monjolinho depois da nova discretização. Comparando as duas figuras, observa-se que a vazão de pico aumentou para os três métodos, isso ocorreu devido ao 
acréscimo de duas sub-bacias e conseqüentemente a ampliação do número de trechos, aumentando a discretização da rede de macrodrenagem de São Carlos.

Na Tabela 18 encontram-se os valores para cada vazão de pico pelo método de Nash, SCS e Diaz e Tucci, onde através desta tabela pode-se observar o aumento significativo das vazões.

Tabela 18 - Valores da vazão de pico associado ao tempo para os três métodos, seções 7.2 e 11.2 .

\begin{tabular}{|c|c|c|c|c|}
\hline \multirow{2}{*}{ Método } & \multicolumn{2}{|c|}{$\begin{array}{c}\text { Figura 32 } \\
\text { (sem modificações) }\end{array}$} & \multicolumn{2}{c|}{$\begin{array}{c}\text { Figura 33 } \\
\text { (com modificações) }\end{array}$} \\
\cline { 2 - 5 } & $\begin{array}{c}\text { Vazão de Pico } \\
\left(\mathbf{m}^{3} / \mathbf{s}\right)\end{array}$ & $\begin{array}{c}\text { Tempo } \\
(\mathbf{h})\end{array}$ & $\begin{array}{c}\text { Vazão de Pico } \\
\left(\mathbf{m}^{\mathbf{3}} / \mathbf{s}\right)\end{array}$ & $\begin{array}{c}\text { Tempo } \\
\text { (h) }\end{array}$ \\
\hline NASH & 145,99 & 0,65 & 173,75 & 0,65 \\
\hline SCS & 107,50 & 1,00 & 131,75 & 0,70 \\
\hline DIAZ E TUCCI & 102,70 & 1,00 & 117,14 & 1,00 \\
\hline
\end{tabular}

As análises feitas das Figuras 32 a 33 serviram para observar a sensibilidade dos três métodos na influência dos hidrogramas, com a nova discretização realizada e na comparação entre os três métodos de cada figura, podendo-se ressaltar que o método de Nash gerou vazões de pico visivelmente maiores em relação aos outros dois.

Nas próximas figuras, para continuar com a análise e comparação entre os hidrogramas de cheia alterou-se os valores do número de deflúvio $(\mathrm{N})$ e do grau de vegetação (PP), do arquivo de dados SUBDAD. Esta alteração foi feita sem levar em consideração critério algum, pois o objetivo inicial era saber o grau de sensibilidade dos parâmetros N e PP na obtenção dos hidrogramas. Para se fazer esta simulação optou-se por áreas menos urbanizadas para sentir a sensibilidade dos parâmetros $\mathrm{N}$ e PP, e as seções escolhidas para se fazer esta análise e comparação foi a seção 1.7, que pertence ao Rio Monjolinho e a seção 2.3 do Córrego Santa Maria Madalena.

Comparação da seção 1.7 (nova discretização) com a seção 1.7 (nova discretização com diminuição de $10 \%$ no grau de vegetação (PP) e um aumento de 5 unidades no número de deflúvio $(\mathrm{N}))$ 
Seção 1.7 (nova discretização)

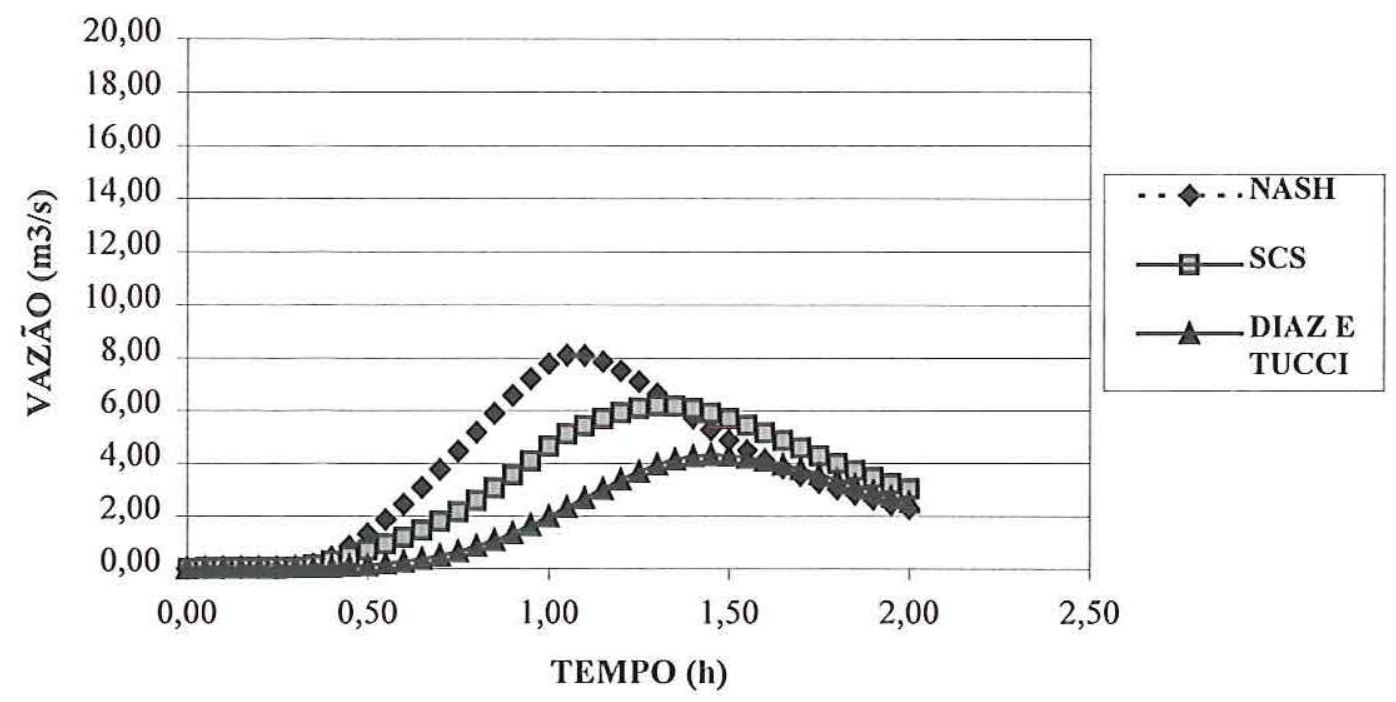

Figura 34 - Hidrogramas de cheia da seção 1.7.

Seção 1.7 (nova discretização com modificação no PP e N)

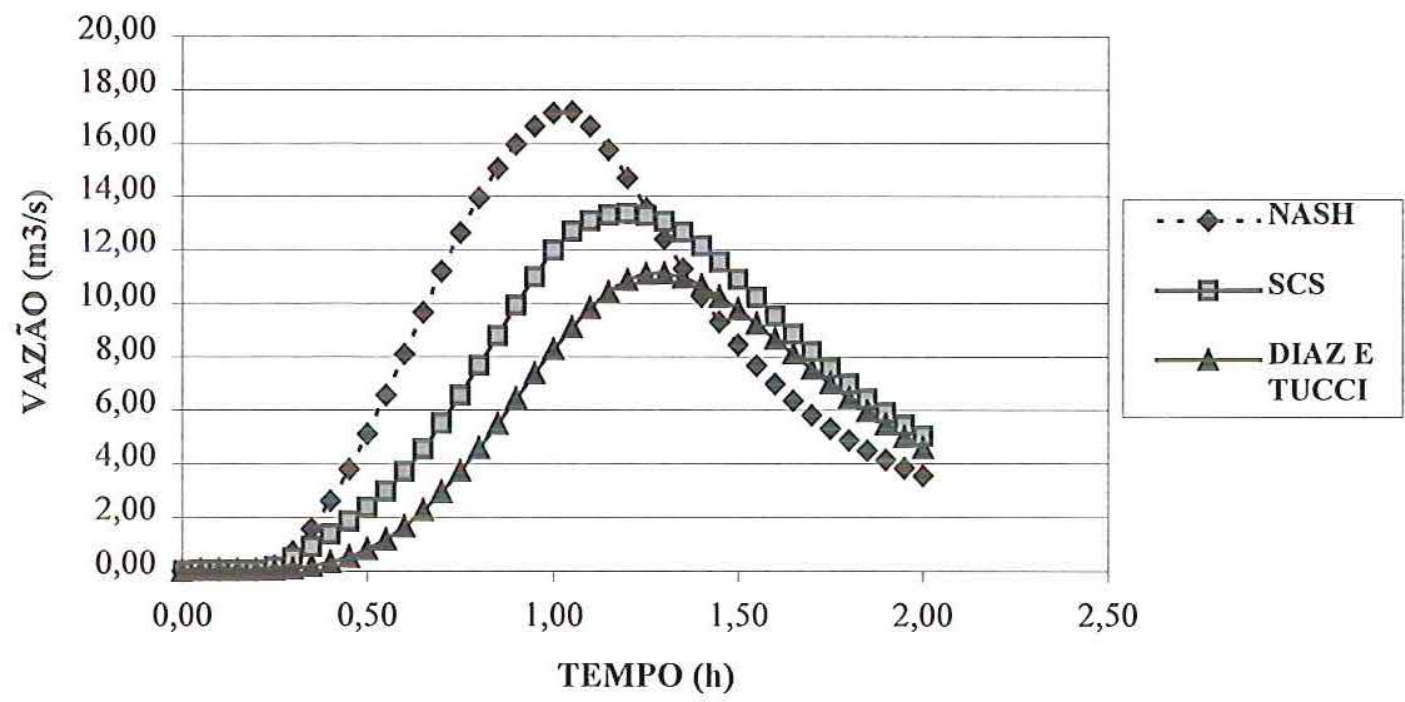

Figura 35 - Hidrogramas de cheia da seção 1.7, com alteração no PP e N.

Comparação da seção 2.3 (nova discretização) com a seção 2.3 (nova discretização com diminuição de $10 \%$ no grau de vegetação (PP) e um aumento de cinco unidades no número de deflúvio $(\mathrm{N})$ ) 
Seção 2.3 (nova discretização)

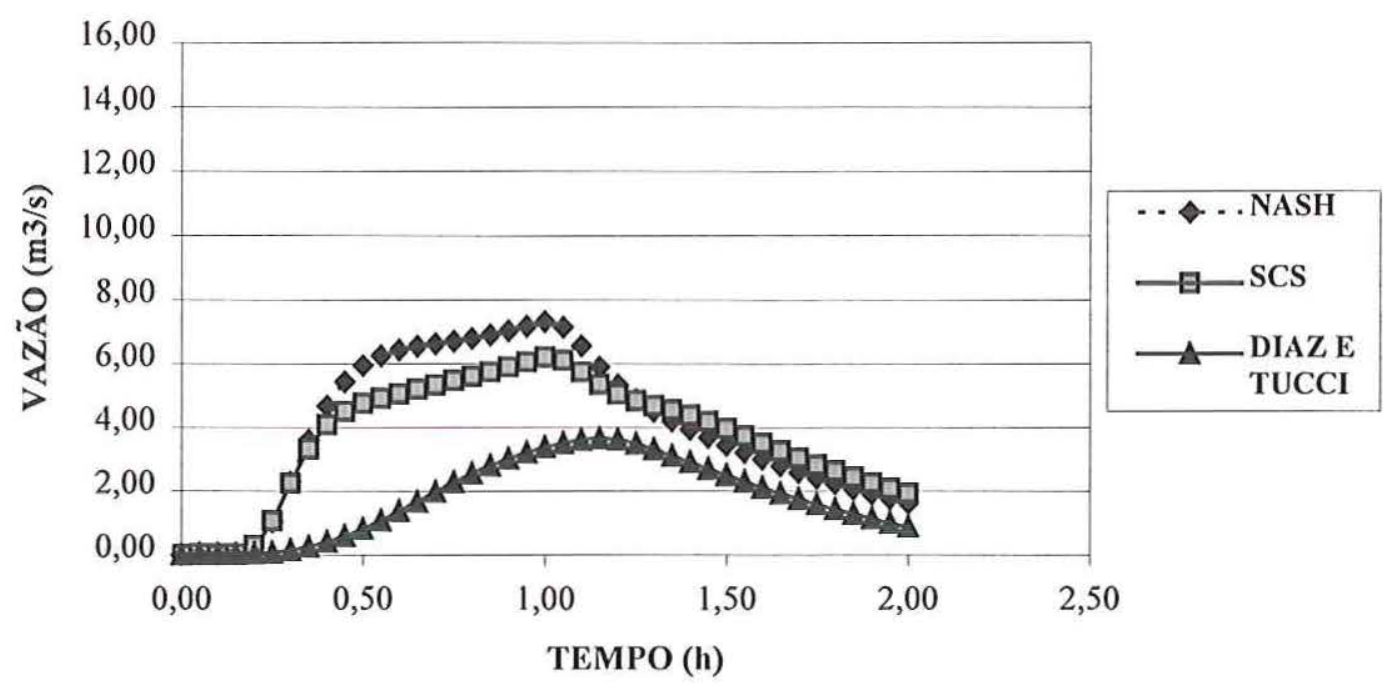

Figura 36 - Hidrogramas de cheia da seção 2.3.

Seção 2.3 (nova discretização com modificação no PP e N)

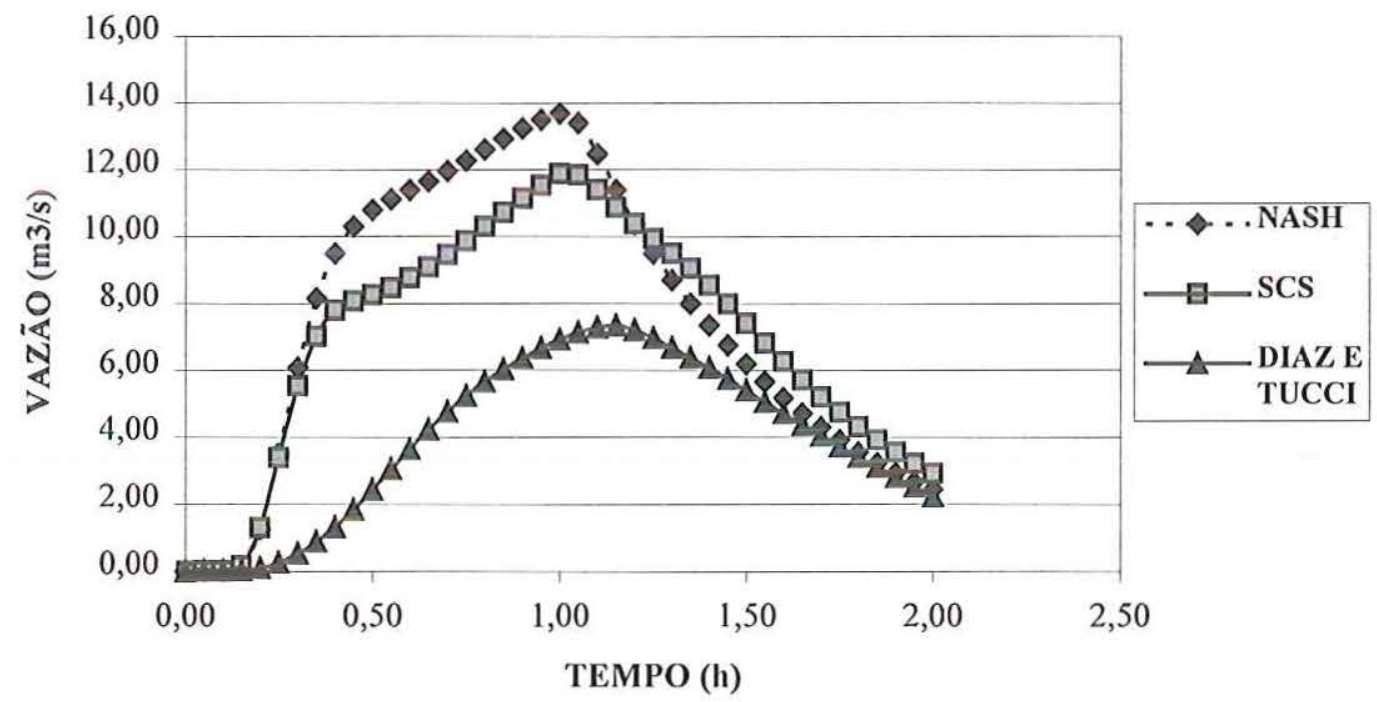

Figura 37 - Hidrogramas de cheia da seção 2.3, com alteração no PP e N.

Através da análise e comparação feita entre os hidrogramas das Figuras 34, 35, 36 e 37, pode-se determinar nas Figuras 34 e 36 que apresentam os hidrogramas de cheia nas seções 1.7 e 2.3 com as modificações já mencionadas, em relação às Figuras 35 e 37, que representam as seções 1.7 e 2.3 com as modificações citadas e também 
com um aumento de 5 unidades no número de deflúvio e uma diminuição de $10 \%$ no grau de vegetação, que os hidrogramas praticamente dobraram a vazão de pico. Por meio de várias simulações realizadas verificou-se a elevação do pico dos hidrogramas pelos três métodos, pois ao alterar os valores de N e PP a área ficou mais impermeável, além disso, observou-se que o N é mais sensível do que o PP. As Tabelas 19 e 20 mostram nitidamente esta elevação na vazão pelos três métodos, nas seções determinadas.

Tabela 19 - Valores da vazão de pico associado ao tempo para os três métodos, seção

1.7 .

\begin{tabular}{|c|c|c|c|c|}
\hline \multirow{2}{*}{ Método } & \multicolumn{2}{|c|}{$\begin{array}{c}c \mid \\
\text { (sem mora 34 }\end{array}$} & \multicolumn{2}{c|}{$\begin{array}{c}\text { Figura 35 } \\
\text { (com modificações) }\end{array}$} \\
\cline { 2 - 5 } & $\begin{array}{c}\text { Vazão de Pico } \\
\left(\mathbf{m}^{\mathbf{3}} / \mathbf{s}\right)\end{array}$ & $\begin{array}{c}\text { Tempo } \\
\text { (h) }\end{array}$ & $\begin{array}{c}\text { Vazão de Pico } \\
\left(\mathbf{m}^{3} / \mathbf{s}\right)\end{array}$ & $\begin{array}{c}\text { Tempo } \\
\text { (h) }\end{array}$ \\
\hline NASH & 8,10 & 1,05 & 17,17 & 1,05 \\
\hline SCS & 6,17 & 1,30 & 13,35 & 1,20 \\
\hline DIAZ E TUCCI & 4,30 & 1,45 & 11,10 & 1,30 \\
\hline
\end{tabular}

Tabela 20 - Valores da vazão de pico associado ao tempo para os três métodos, seção 2.3.

\begin{tabular}{|c|c|c|c|c|}
\hline \multirow{2}{*}{ Método } & \multicolumn{2}{|c|}{$\begin{array}{c}\text { Figura } 36 \\
\text { (sem modificações) }\end{array}$} & \multicolumn{2}{|c|}{$\begin{array}{c}\text { Figura } 37 \\
\text { (com modificações) }\end{array}$} \\
\hline & $\begin{array}{c}\text { Vazão de Pico } \\
\left(\mathrm{m}^{3} / \mathrm{s}\right)\end{array}$ & $\begin{array}{l}\text { Tempo } \\
\text { (h) }\end{array}$ & $\begin{array}{c}\text { Vazão de Pico } \\
\left(\mathrm{m}^{3} / \mathrm{s}\right)\end{array}$ & $\begin{array}{l}\text { Tempo } \\
\text { (h) }\end{array}$ \\
\hline NASH & 7,33 & 1,00 & 13,69 & 1,00 \\
\hline SCS & 6,21 & 1,00 & 11,88 & 1,00 \\
\hline DIAZ E TUCCI & 3,65 & 1,15 & 7,34 & 1,15 \\
\hline
\end{tabular}

Depois de ter feito várias simulações e observado que o número de deflúvio influi muito mais do que o grau de vegetação na obtenção dos hidrogramas de cheias, resolveu determinar para as seções 1.12, 4.2, 6.2 e 7.4, dos principais córregos pertencentes à Bacia do Monjolinho e que fazem parte deste estudo, as vazões de pico para diversos $\mathrm{N}$.

As simulações realizadas com a nova discretização (ANEXO D) iniciaram com $\mathrm{N}$ igual a 65 , onde o grau de urbanização da área considerada é bastante baixo, e finalizou com 95 que é um valor considerado por diversos autores, para uma área com um alto grau de urbanização. As simulações foram feitas para sete valores de $\mathrm{N}$ entre 
65 e 95, variando de cinco em cinco, e depois se fez a relação da vazão de pico com o N considerado para cada simulação dos hidrogramas de cheia das quatro seções citadas. As Figuras 38, 39 e 40 foram apresentadas para mostrar que realmente quanto maior o $\mathrm{N}$, maior a vazão de pico e os períodos de retorno utilizados foram 10, 25 e 50 anos, para uma duração (DC) de 2 horas.

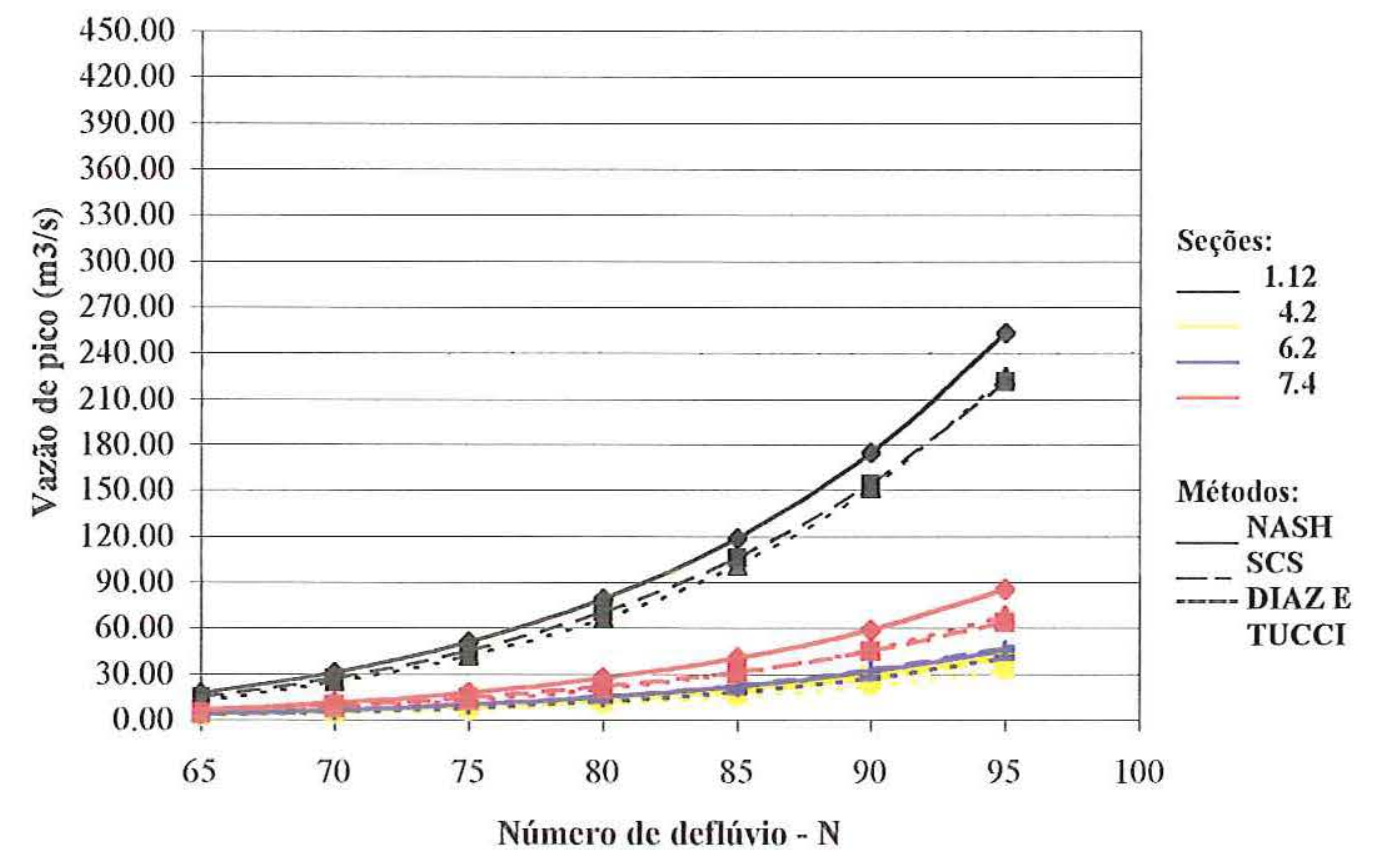

Figura 38 - Influência do número de deflúvio na vazão de pico, para TR = 10 anos. 


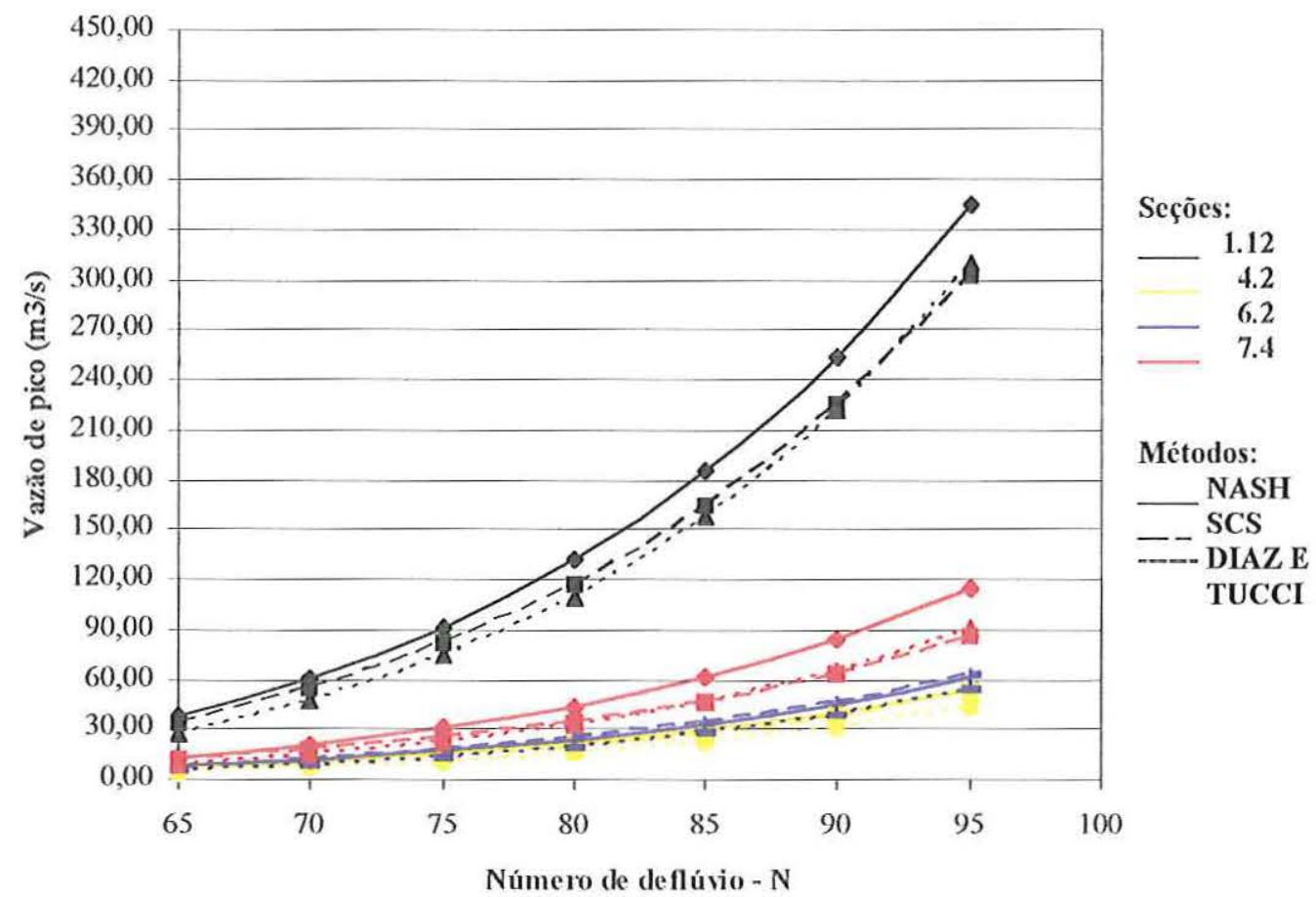

Figura 39 - Influência do número de deflúvio na vazão de pico, para TR = 25 anos.

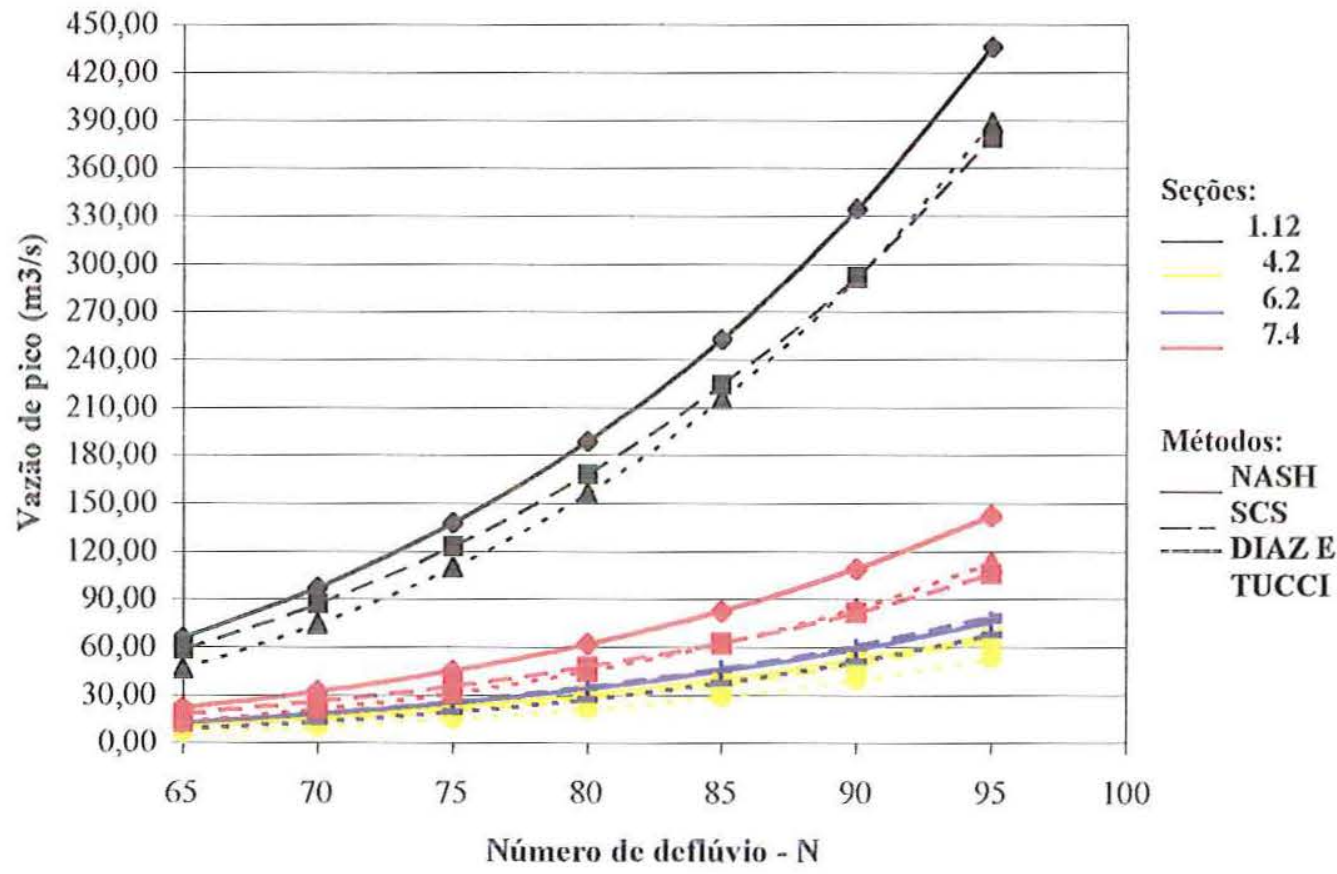

Figura 40 - Influência do número de deflúvio na vazão de pico, para TR = 50 anos.

Na apresentação de todas as figuras com a obtenção dos hidrogramas de cheia, 
com exceção das Figuras 38, 39 e 40, mostraram claramente, que o método de Nash está superdimensionado em relação aos outros dois, que por todas as simulações realizadas tornou-se decisiva a exclusão do uso do método de Nash.

Para poder ficar real o que se está afirmando e que possa dar credibilidade ao trabalho, decidiu-se fazer comparações com dados medidos, por meio de um hidrograma observado. Devido a isso se fez necessário a utilização de dados medidos em outros trabalhos para comparar e assegurar com o que se analisou.

\subsection{Hidrograma observado}

O Hidrograma observado utilizado neste estudo foi obtido a partir dos trabalhos de Machado (1981) e Silva (2003). O primeiro trabalho são dados medidos em 1980 e o segundo são dados de 2000, a escolha feita por estes dois trabalhos foi devido à possibilidade de inserção de valores no arquivo de dados no modelo utilizado, podendo obter duas alternativas para verificação do modelo e comparação dos hidrogramas gerados pelos três métodos com o hidrograma observado.

O modelo desenvolvido e utilizado por Silva (2003) é um modelo hidrológico distribuído e a concepção deste, parte da premissa de que toda a área da bacia possa ser representada por células derivadas de um Modelo Numérico de Terreno (MNT). Em cada célula é especificado o equacionamento hidráulico-hidrológico e propagado os escoamentos para as células de jusante. O Modelo HIDRO-SHS foi aplicado a uma pequena bacia hidrográfica urbana, onde se optou pela Bacia do Gregório, e é estruturado de forma a se considerar os processos de detenção superficial, infiltração, escoamento de superfície e galerias pluviais, os quais são propagados até alcançarem os canais de drenagem.

Machado (1981) desenvolveu e aplicou um modelo hidrológico determinístico e distribuído para bacias urbanas com considerações sobre a micro e macrodrenagem da Bacia do Gregório, onde realizou levantamento das seções transversais dos canais de drenagem e coleta de dados chuva-vazão. Na modelagem foram considerados os principais processos do ciclo hidrológico urbano, tais como infiltração, retenção superficial, geração de escoamento de superfície, propagação em sarjetas, galerias e canais. 
O Modelo DRENG-P21A desenvolvido por Machado (1981) simula a infiltração utilizando a equação de Horton, além disso, simula o escoamento de superfície e a propagação do deflúvio nas sarjetas, o que não são simulados no modelo EESC. Já a propagação do escoamento em galerias e canais foi feita através do equacionamento de onda cinemática, que considerou esquemas linear e não-linear. $\mathrm{O}$ esquema não linear assegura a convergência, enquanto que a parte linear do modelo dá maior rapidez aos cálculos.

A maneira como a bacia real é simulada tem duas características importantes: a primeira é que os quarteirões são discretizados como sub-bacias fornecedoras de escoamento de superfície e as ruas são os canais condutores daquele escoamento até as galerias e/ou canais drenantes. A segunda característica é que o esquema utilizado é bastante flexível para simular qualquer traçado real urbanístico e de rede de galerias.

A única deficiência do modelo DRENG-P21A é não simular propagação de escoamento de superfície de uma sub-bacia para outra, o que pode acontecer em bacias urbanas com grande porção de área rural não suficientemente cortada por córregos formadores do canal principal drenante, como é o caso do modelo EESC.

As pequenas diferenças entre hidrogramas simulados e observados apresentados neste trabalho mostram que o modelo EESC é apto a simular o deflúvio de pico, o tempo de deflúvio de pico e a forma do hidrograma dentro de uma margem de erro satisfatória, mas o modelo não foi suscetível a simular o volume total em relação aos dois hidrogramas observados.

Os modelos HIDRO-SHS e DRENG-P21A incluem na sua simulação processos hidrológicos que o modelo EESC não considera, por este motivo o hidrograma gerado por este modelo que considera a propagação de onda na rede de canais principais, através do método da onda cinemática que antecede o pico de cheia, pois os dois primeiros modelos citados retêm facilmente a precipitação inicial, por não obter o método da onda cinemática que retarda o tempo de pico.

\section{Cenário de Análise}

Com a finalidade de avaliar o impacto do crescimento urbano sobre a macrodrenagem, foram escolhidos dois eventos:

- Evento 1 - condição de urbanização da Bacia do Gregório em 1980, no Mercado Municipal, onde tem registrado maiores números de inundações 
e considerada como a primeira situação de referência em relação aos dados observados no trabalho de Machado (1981);

- Evento 2 - condição de urbanização da Bacia do Gregório em 2000, próximo ao Fórum, e considerada como a segunda situação de referência em relação aos dados observados no trabalho de Silva (2003).

\section{Precipitação de Projeto}

A precipitação de projeto foi obtida da curva de intensidade-duração-freqüência do posto da bacia considerada em cada trabalho, com maior série histórica e a distribuição espacial de acordo com o maior evento ocorrido.

\section{Previsões}

Os parâmetros dos arquivos de dados que caracterizam fisiograficamente a bacia foram estimados com base na rede de configuração de macrodrenagem da cidade de São Carlos (ANEXO C), mapas e fotos aéreas da mesma. Os mapas analisados para se obter os parâmetros estão apresentados a seguir, e foram retirados do Relatório Pólis que está arquivado em CD-ROM, no ANEXO B:

- Mapa 03: Área Urbana de São Carlos - Expansão Urbana;

- Mapa 04: Área Urbana de São Carlos - Áreas de Preservação Ambiental;

- Mapa 05: Área Urbana de São Carlos - Mapeamento Geotécnico;

- Mapa 23: Área Urbana de São Carlos - Uso do Solo;

- Mapa 24: Área Urbana de São Carlos - Zoneamento;

- Mapa 27: Área Urbana de São Carlos - Densidade Demográfica;

- Mapa 28: Área Urbana de São Carlos - Acréscimo e Decréscimo Populacional;

- Mapa 30: Área Urbana de São Carlos - Vazios Urbanos.

As fotos aéreas utilizadas estão mostradas nas Figuras 41 e 42, a seguir: 


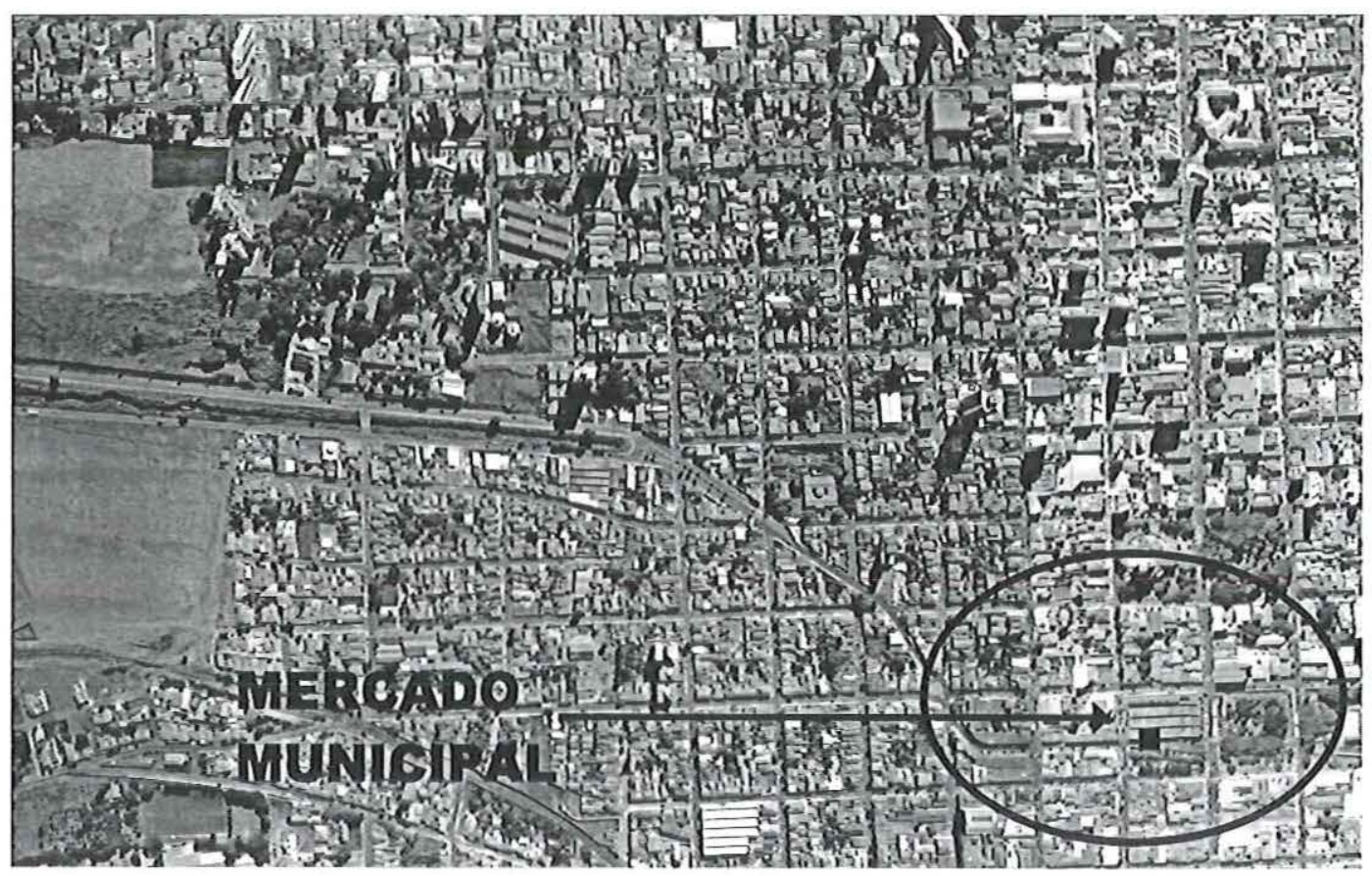

Figura 41 - Foto aérea da região do Mercado Municipal, onde foram coletados os dados de MACHADO (1981).

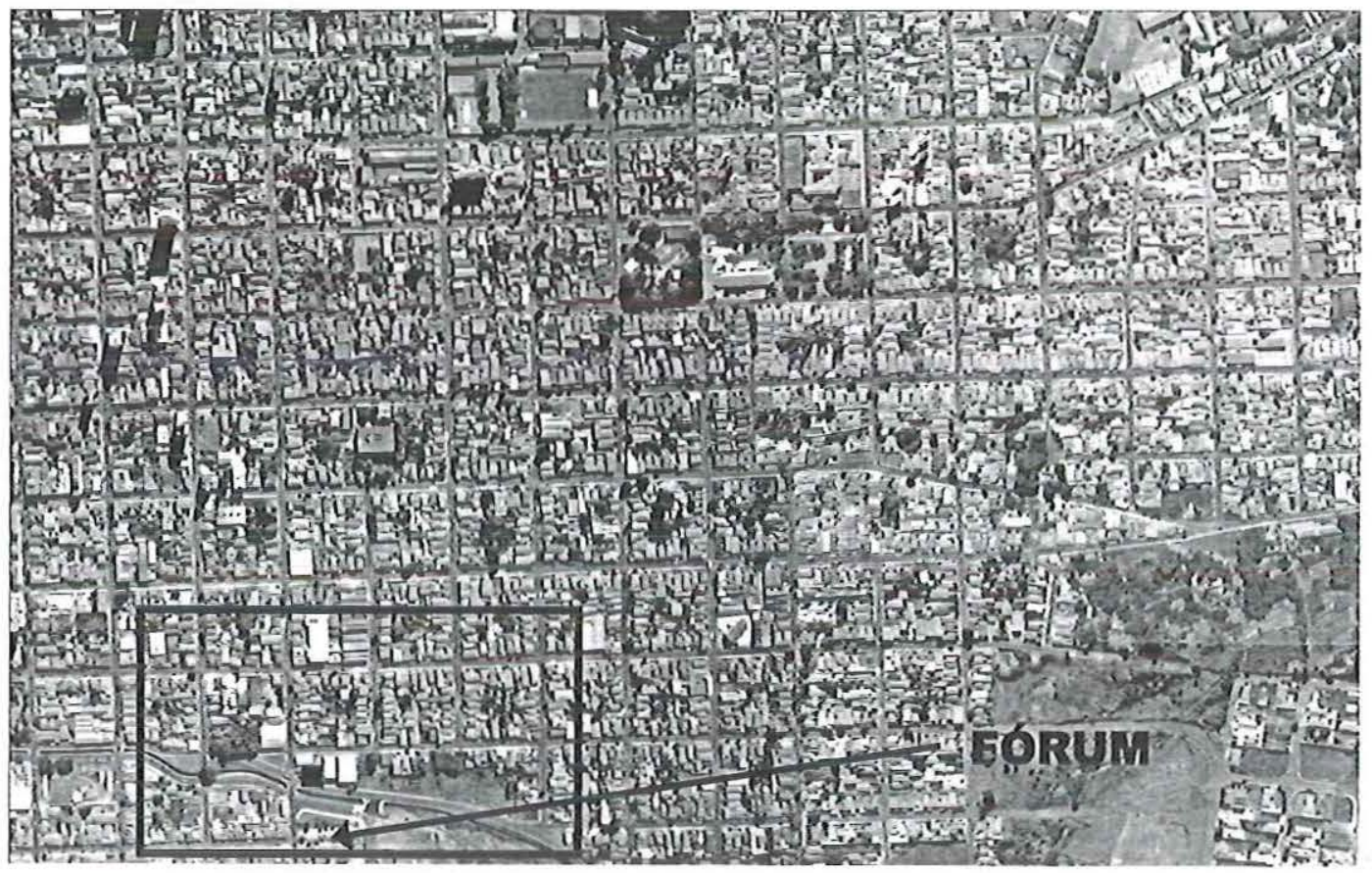

Figura 42 - Foto aérea da região do Fórum, onde foram coletados os dados de SILVA (2003).

Fonte (Figuras 41 e 41): CDCC (2002). 
O ponto preto especificado nas duas fotos aéreas indica o local da seção, onde os dados de precipitação e deflúvio foram coletados. No trabalho de Machado (1981) foram utilizados dois postos para levantamento de linigramas, o primeiro em frente ao Mercado Municipal de São Carlos, com apenas uma régua, teve sua curva-chave levantada. O outro posto, denominado Alfredo Maffei, fica próximo ao exutório da bacia, possui um linígrafo instalado e uma régua.

A escolha da seção do Mercado Municipal foi devido ao levantamento da curvachave ter sido feita apenas para esta seção, pois o segundo posto não teve a sua curvachave levantada, devido à limitação de tempo e a falta de recursos técnicos e humanos, e a transformação linigrama-hidrograma foi feita através da fórmula de vertedores, sem confirmação experimental.

No trabalho de Silva (2003) as informações relativas ao total precipitado e a sua variação no espaço foram obtidas pela instalação de cinco postos pluviográficos, cada posto com um pluviógrafo semi-automático da Campbell Scientific, Inc. dotado de um DataLogger CR10-X. Dos cinco postos instalados, somente dois postos foram dotados de linígrafos no sentido de registrar as descargas em duas seções de controle, onde tiveram a sua curva-chave levantada.

Os locais para instalação dos postos foram selecionados de forma a cobrir toda a área urbanizada da bacia.

A medição de chuva dos cinco postos instalados no Córrego do Gregório, apenas um interessou a este trabalho, primeiramente por ser o único posto que teve sua curvachave levantada, pelo seu local de instalação abranger grande parte da área urbana e, além disso, possuir um linígrafo instalado. O posto escolhido foi o cinco, o qual é chamado pela autora de ESTAÇÃO 5, localiza-se no cruzamento da Rua Campos Sales e Avenida Doutor Alfredo Maffei, próximo ao Fórum de São Carlos.

Este posto pluviográfico e linigráfico entrou em operação no dia sete de janeiro de 2000, onde permaneceu em funcionamento até o início de abril de 2000, e a sua instalação do equipamento para medição de chuva deste posto, teve cerca de 2,5 metros acima do solo a fim de evitar os inconvenientes atos de vandalismo. A Figura 43 mostra o posto 5, ou seja, ESTAÇÃO 5 em funcionamento. 


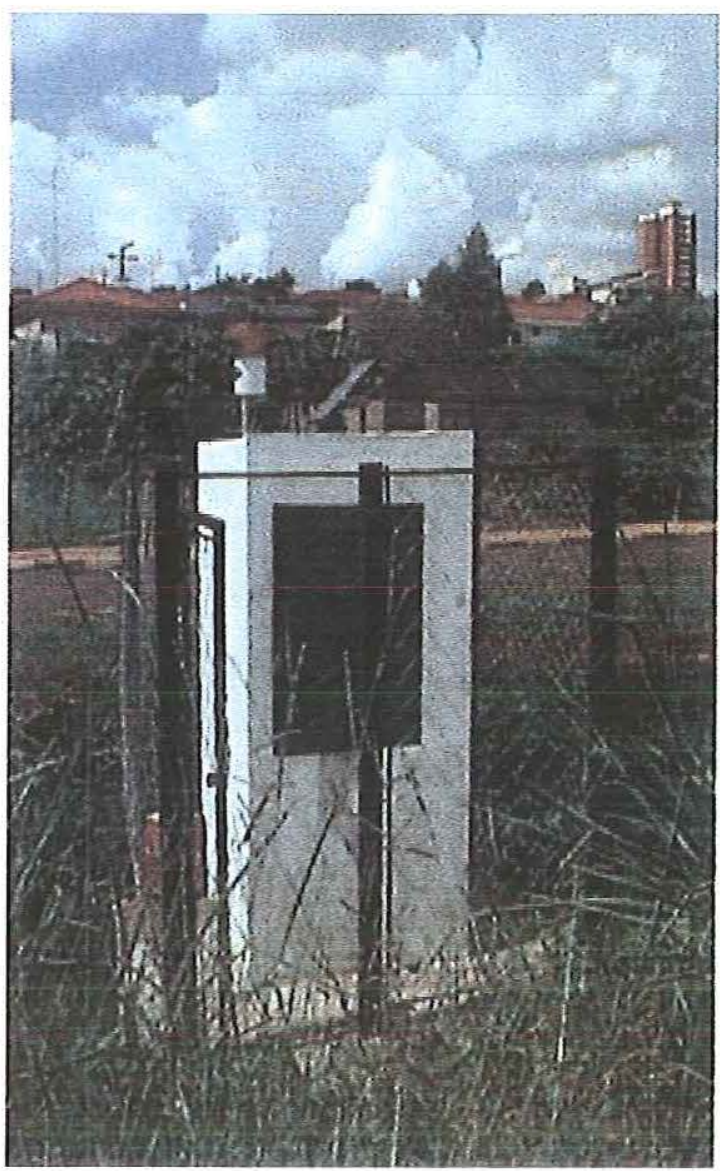

Figura 43 - Posto 5 ao longo do Córrego do Gregório, próximo ao Fórum.

Fonte: Silva (2003, p.87).

\subsubsection{Levantamento da curva-chave da seção do Mercado Municipal}

A obtenção de dados de perfis de velocidade em um canal urbano, segundo Machado (1981), revelou-se tarefa bastante árdua, quer seja pela pouca experiência em medições dessa natureza, quer seja pela inexistência de técnicas e equipamentos adequados, quando da realização das medições. A seção escolhida para as medições foi em frente ao Mercado Municipal de São Carlos. A Figura 44 mostra em perspectiva e em seção transversal o local de medição. 

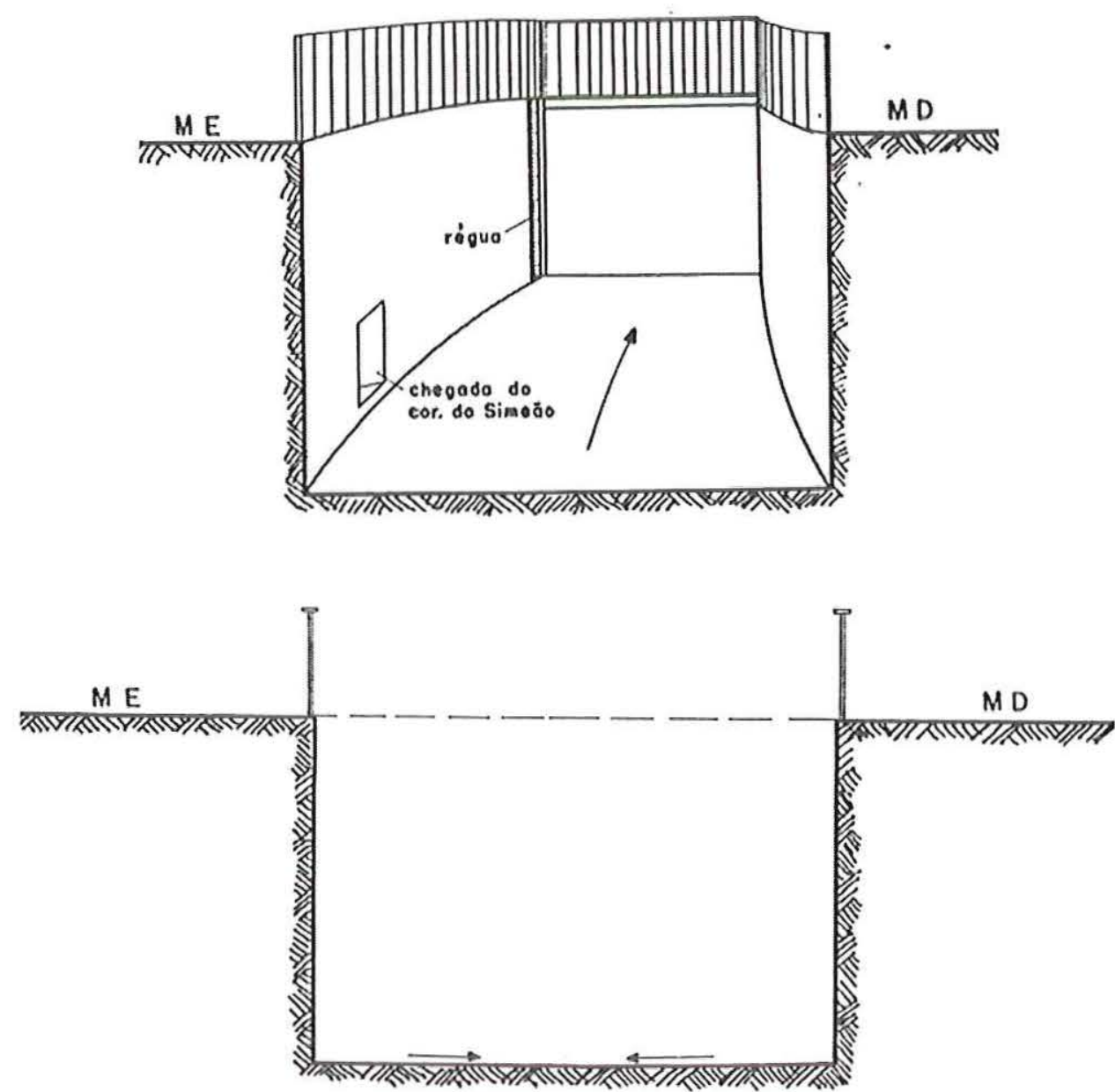

Figura 44 - Córrego do Gregório - Seção de medição do Mercado Municipal.

Fonte: Machado (1981, p.124).

As medições foram feitas com um molinete Siap de eixo horizontal fixando-o a um cabo de aço ao leito do canal, onde este cabo era passado por dentro de um cano de 1/2 polegada, de parede espessa, através do qual era descido o molinete. Por causa de uma série de dificuldades, as leituras de velocidade foram realizadas apenas na seção central do canal e somente a uma profundidade, a cada leitura de régua.

A curva-chave, a qual está representada na Figura 45, teve seus pontos ajustados a uma curva do tipo $\mathrm{Q}=\mathrm{aH}^{\mathrm{b}}$, sendo $\mathrm{Q}$ deflúvio, $\mathrm{H}$ altura d'água e a, b coeficientes, através do método dos mínimos quadrados. 


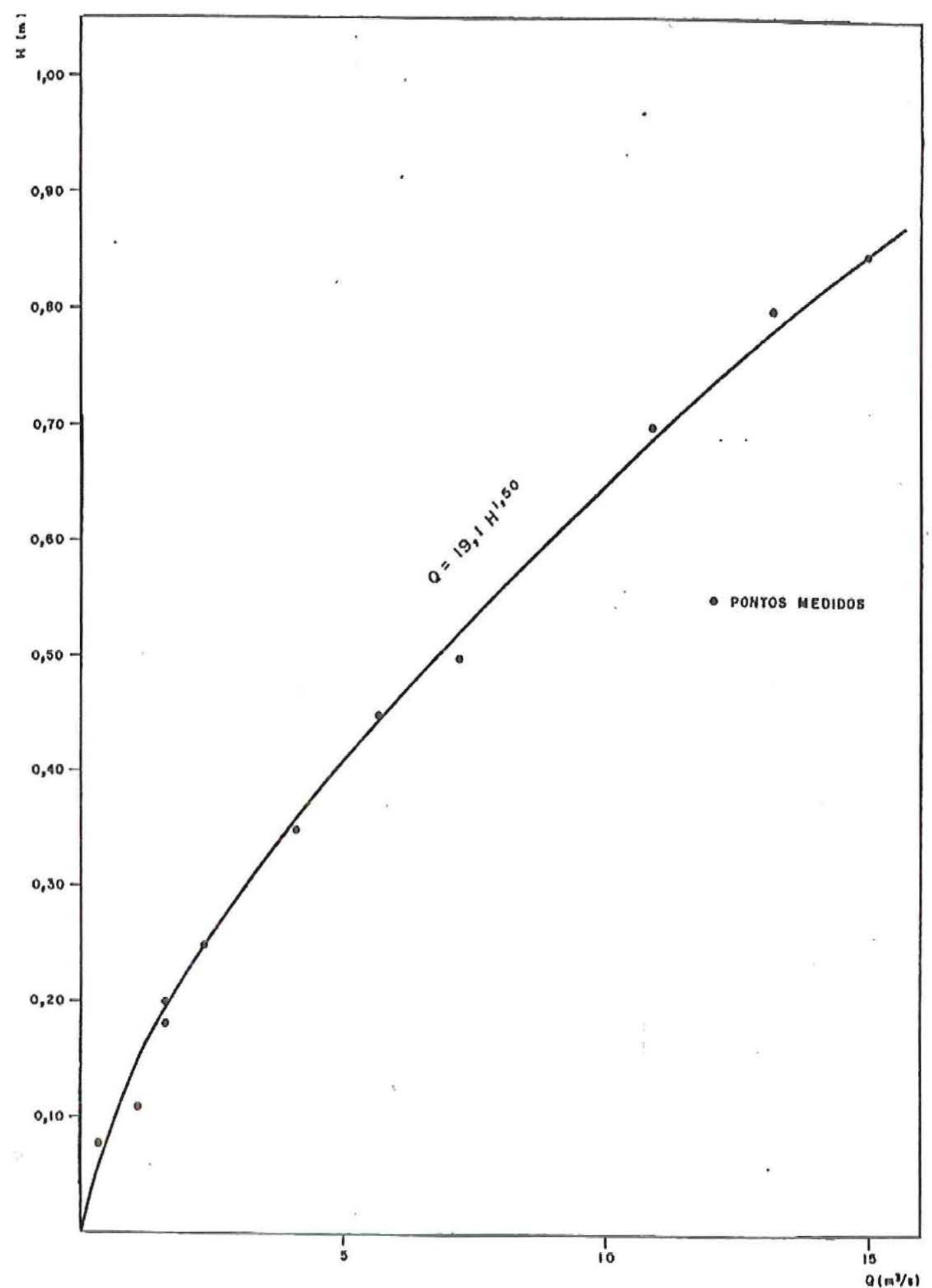

Figura 45 - Curva-Chave do Córrego do Gregório, na seção do Mercado Municipal.

Fonte: Machado (1981, p.128).

5.4.2 Levantamento da curva-chave da seção do Fórum 
Para a obtenção dos hidrogramas de cheias Silva (2003) previu o levantamento da curva-chave das seções de controle 4 e 5, que são postos pluviográfícos e linigráficos, mas como já dito no item 5.4 , apenas o posto 5 teve sua curva-chave levantada. A medição direta de vazão realizada na seção 5 foi com a utilização de um molinete de eixo horizontal e lastro de $50 \mathrm{Kg}$. A Figura 46 mostra os pontos obtidos e a linha de tendência da curva.

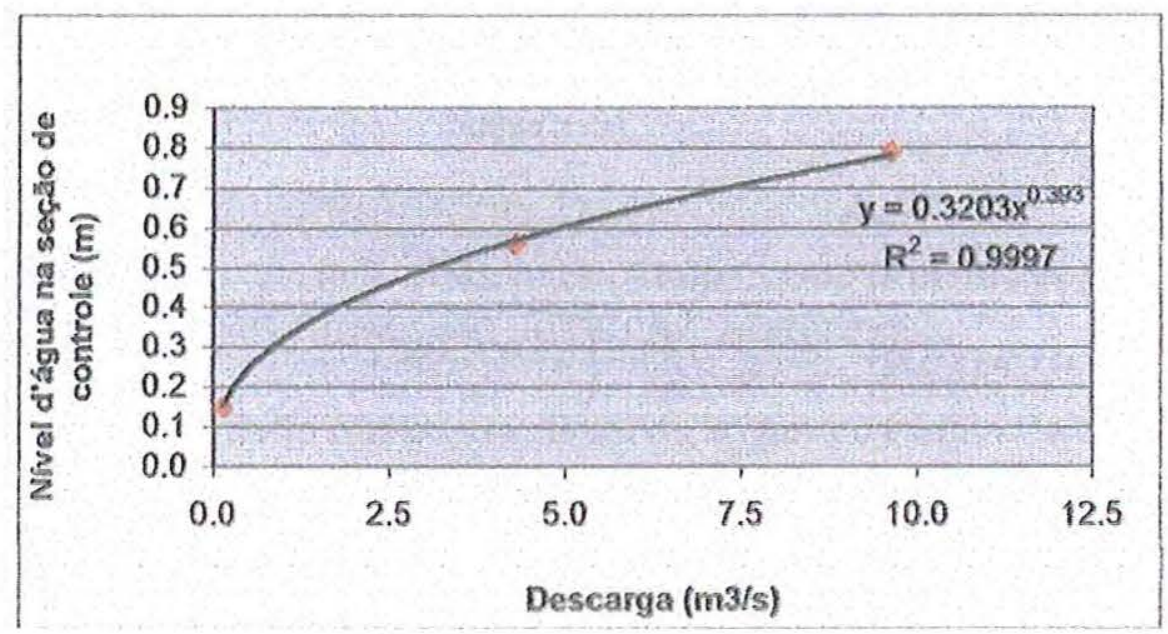

Figura 46 - Curva-chave na seção do posto 5 do Córrego do Gregório.

Fonte: Silva (2003, p.95).

Ao analisar detalhadamente a obtenção da curva-chave de Silva (2003), observou-se que não obtendo o perfil da seção para o local de medição, o que se fez durante o trabalho de medição foi dividir a seção em vários segmentos, para três níveis distintos, obtendo a velocidade média para cada vertical que multiplicada pela área do segmento se determinou a vazão. A vazão final para cada nível d'água foi determinada através do somatório das vazões calculadas para cada segmento. A partir disso, a curvachave foi levantada como está apresentada na Figura 46 onde mostra os pontos obtidos e a linha de tendência da curva.

Com a obtenção dos dados utilizados na curva-chave de Silva (2003), se pode obter uma nova curva-chave, pois o perfil da seção (Figura 47) estava contido neste trabalho e através da equação de Manning, descrita no item 4.2.3, obteve a curva-chave utilizada neste estudo. Os resultados dos dados calculados para a nova curva-chave estão apresentados na Tabela 21. 


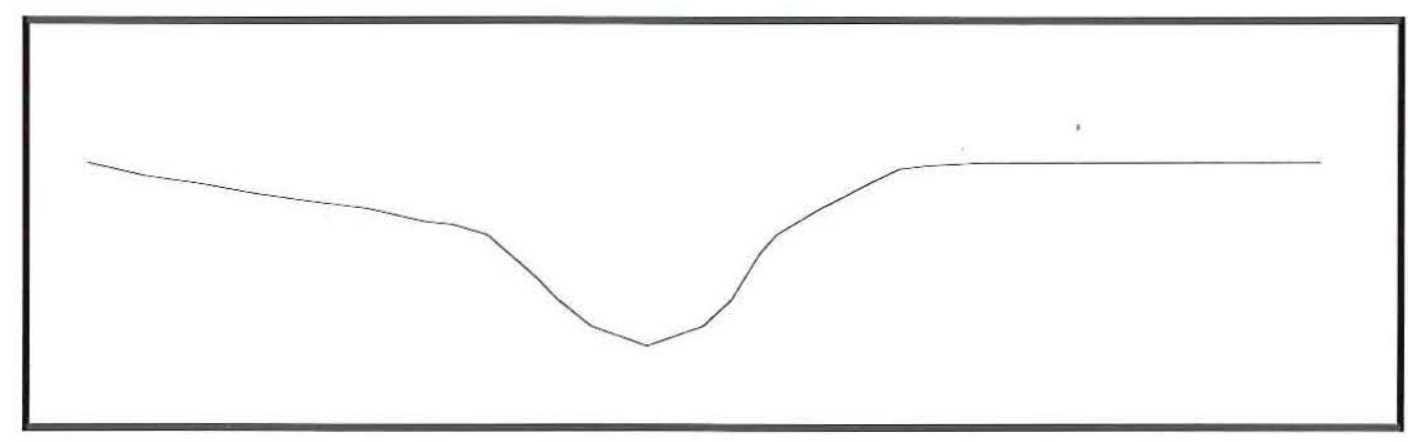

Figura 47 - Perfil da seção transversal de medição dos dados para a curva-chave do trabalho de Silva (2003), seção 6.4 da discretização inicial deste estudo.

Tabela 21 - Descarga para cada evento estimado.

\begin{tabular}{|c|c|c|c|c|c|c|}
\hline $\begin{array}{c}\mathbf{H} \\
(\mathbf{m})\end{array}$ & $\mathbf{n}$ & $\begin{array}{c}\mathbf{I} \\
(\mathbf{m} / \mathbf{m})\end{array}$ & $\begin{array}{c}\mathbf{A} \\
\left(\mathbf{m}^{\mathbf{2}}\right)\end{array}$ & $\begin{array}{c}\mathbf{P} \\
\mathbf{( m )}\end{array}$ & $\begin{array}{c}\mathbf{R h} \\
\mathbf{( m )}\end{array}$ & $\begin{array}{c}\mathbf{Q} \\
\left(\mathbf{m}^{\mathbf{3}} / \mathbf{s}\right)\end{array}$ \\
\hline 0,15 & 0,025 & 0,0186 & 0,075 & 1,044 & 0,072 & 0,0707 \\
\hline 0,56 & 0,025 & 0,0186 & 0,9129 & 2,968 & 0,3076 & 2,2692 \\
\hline 0,80 & 0,025 & 0,0186 & 1,693 & 3,71 & 0,4563 & 5,4743 \\
\hline
\end{tabular}

Os parâmetros referentes à Tabela 21 significam:

H - nível d'água na seção de controle em metros;

$\mathrm{n}$ - coeficiente de rugosidade de Manning;

$\mathrm{I}$ - declividade de fundo do canal em $\mathrm{m} / \mathrm{m}$;

A - área molhada da seção do canal em $\mathrm{m}^{2}$;

$\mathrm{P}$ - perímetro molhado da seção;

$\mathrm{Rh}$ - raio hidráulico em m;

$\mathrm{Q}$ - vazão $\mathrm{em} \mathrm{m}^{3} / \mathrm{s}$.

A nova curva-chave obtida para este trabalho em relação aos dados medidos por Silva (2003), está apresentada pela Figura 48, através da qual mostra os pontos de vazão relacionados a cada altura d'água e a linha de tendência. 


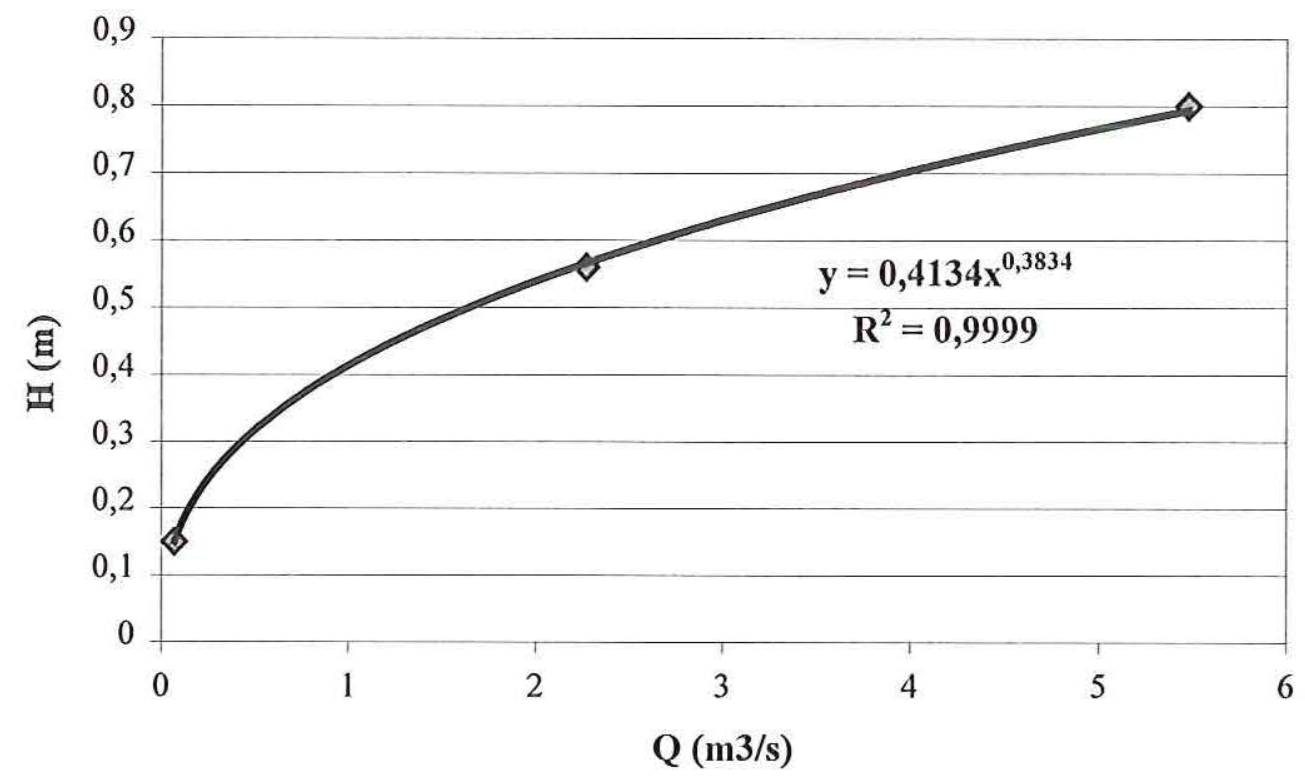

Figura 48 - Curva-chave utilizada neste trabalho, a partir dos dados de Silva (2003).

\subsubsection{Ajuste dos parâmetros do modelo EESC}

O ajuste foi realizado com base nos parâmetros do arquivo de dados SUBDAD, que fornece os dados relativos às sub-bacias do sistema de macrodrenagem de São Carlos (ANEXO F). Os valores ajustados foram dos parâmetros $\mathrm{N}$ e PP, pois os dois estão relacionados com o grau de impermeabilização da bacia e os valores determinados inicialmente para eles, estão em relação ao ano de 1994.

$\mathrm{O}$ ajuste feito no modelo para comparação dos três métodos de obtenção de Hidrograma Unitário, com o Hidrograma Observado de Machado (1981), foi diminuir os valores de $\mathrm{N}$ e aumentar os valores de PP, de acordo com a situação em que se encontrava a área de estudo da Bacia do Monjolinho, em 1980, ano em que foram medidos os dados do trabalho de Machado. Os valores ajustados para N e PP, foram determinados através do material citado no item 5.4 .

Para o trabalho de Silva (2003) os ajustes dos parâmetros N e PP foram feitos da mesma maneira utilizada para o trabalho de Machado, mas só que os valores foram especificados com relação à situação da região em 2000, pois este foi o ano de obtenção dos dados medidos no trabalho de Silva.

As simulações para obtenção dos hidrogramas foram feitas para as seções 6.5 e 6.4, especificadas na configuração da rede de macrodrenagem de São Carlos (ANEXO 
C), sendo a primeira seção para comparar com o Hidrograma Observado de Machado (Hidrograma 1) e a segunda seção para comparar com o Hidrograma Observado gerado a partir dos dados medidos por Silva (Hidrograma 2). Estas simulações foram finalizadas quando se conseguiu ajustar os parâmetros $\mathrm{N}$ e PP com a aproximação dos três hidrogramas unitários deste estudo e os dois hidrogramas observados.

Os hidrogramas estão apresentados nas Figuras 49 e 50, onde se pode fazer a análise e comparação dos três métodos utilizados para gerar hidrogramas unitários com cada hidrograma observado. As simulações realizadas na seção 6.5 tiveram um período de retorno de 1.85 anos e 0.92 de hora para a duração de chuva, onde na Figura 49 mostra o Hidrograma Observado 1 referente ao dia 22 de fevereiro de 1980, que pelo trabalho de Machado apresentou uma precipitação com duração e intensidade máxima, em relação às demais.

A Figura 50 apresenta uma situação mais atual, onde o Hidrograma Observado 2 foi obtido a partir da duração e intensidade máxima de chuva do dia 06 de fevereiro de 2000 através dos dados medidos por Silva (2003), onde as simulações foram feitas para um período de retorno de 1.59 anos e 2.00 horas de duração de chuva.

O período de retorno (TR) foi obtido com a utilização da fórmula de intensidade-duração-frequência usada para a cidade de São Carlos, apresentada no item 4.1, que pela qual obteve TR em função da intensidade média da chuva e do tempo de duração da chuva. Os valores das vazões de pico obtidos nos hidrogramas das Figuras 49 e 50 estão especificados na Tabela 22. 


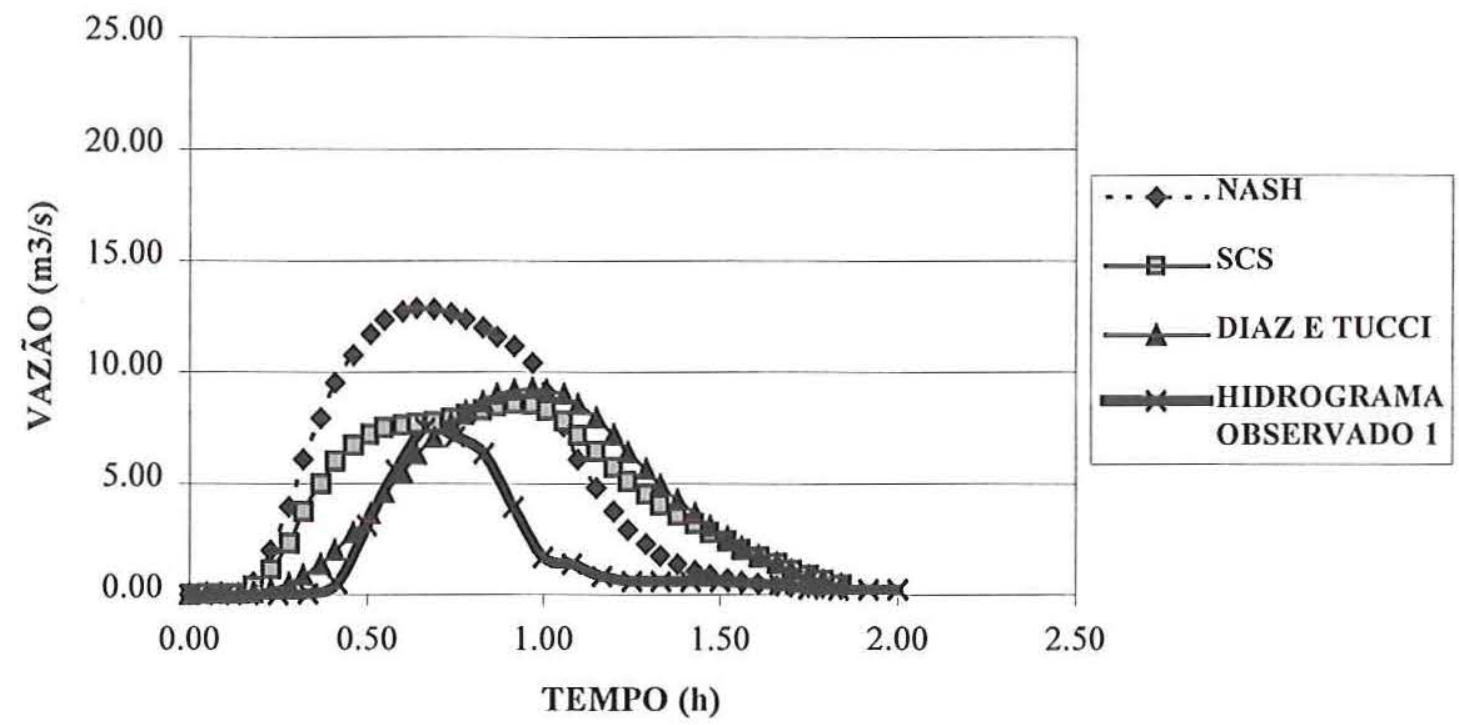

Figura 49 - Hidrogramas calculados e hidrograma observado para a seção do Mercado Municipal.

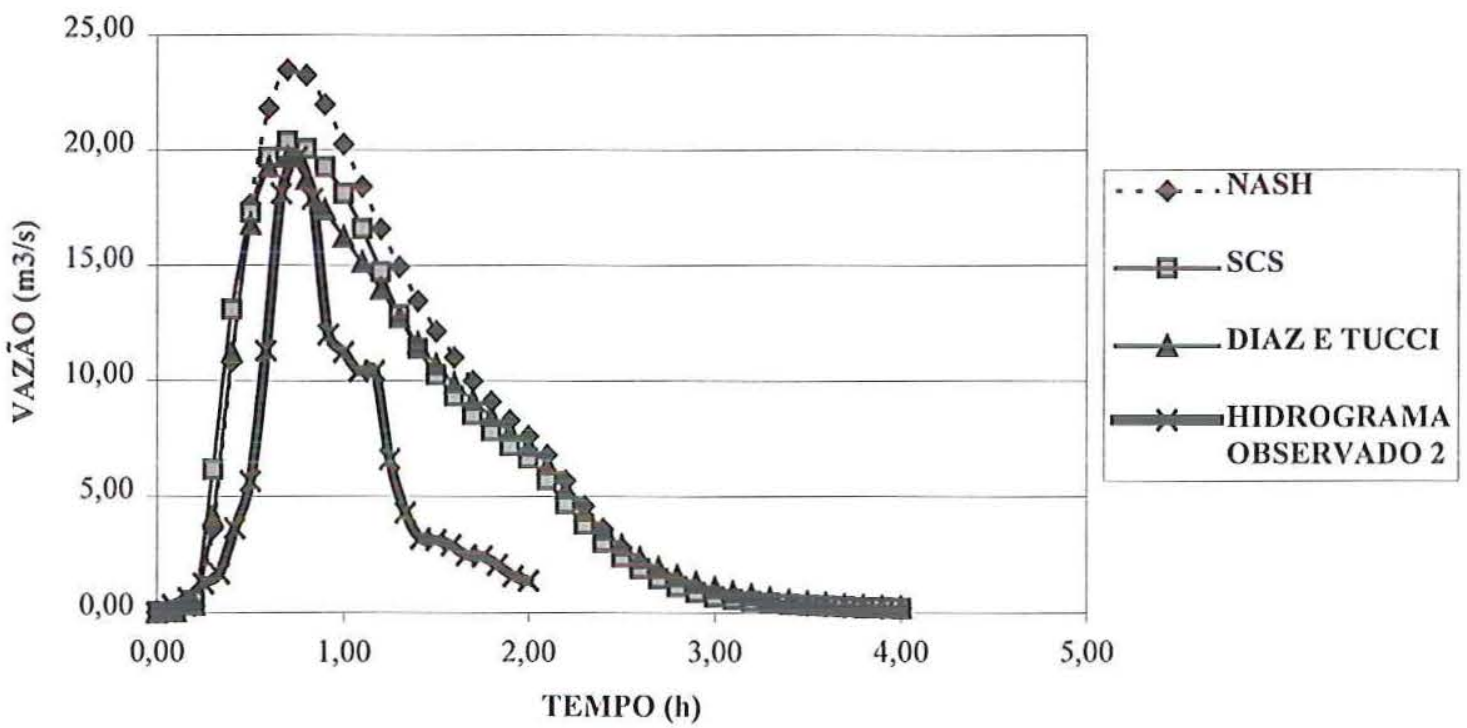

Figura 50 - Hidrogramas calculados e hidrograma observado para a seção do Fórum. 
Tabela 22 - Valores da vazão de pico associado ao tempo para os três métodos e para os hidrogramas observados 1 e 2 .

\begin{tabular}{|c|c|c|c|c|}
\hline \multirow{2}{*}{ Método } & \multicolumn{2}{|c|}{ Figura 49 } & \multicolumn{2}{c|}{ Figura 50 } \\
\cline { 2 - 5 } & $\begin{array}{c}\text { Vazão de Pico } \\
\left(\mathbf{m}^{3} / \mathbf{s}\right)\end{array}$ & $\begin{array}{c}\text { Tempo } \\
\text { (h) }\end{array}$ & $\begin{array}{c}\text { Vazão de Pico } \\
\left(\mathbf{m}^{3} / \mathbf{s}\right)\end{array}$ & $\begin{array}{c}\text { Tempo } \\
\text { (h) }\end{array}$ \\
\hline NASH & 12,87 & 0,64 & 23,49 & 0,70 \\
\hline SCS & 8,64 & 0,92 & 20,38 & 0,70 \\
\hline DIAZ E TUCCI & 9,27 & 0,97 & 19,67 & 0,70 \\
\hline OBSERVADO & 7,50 & 0,67 & 19,69 & 0,75 \\
\hline
\end{tabular}

\subsubsection{Verificação do modelo EESC}

A verificação é o processo de determinação da exatidão do modelo de simulação, que representa a descrição conceitual do sistema. Na fase de verificação dados de entrada reais e parâmetros do modelo são utilizados para gerar resultados que serão comparados com os dados existentes, para se verificar se o modelo simula adequadamente o sistema.

A operação do sistema de sub-bacias de parte da Bacia do Monjolinho foi simulada nas seções 6.5 e 6.4, com finalidade de fazer a verificação do modelo matemático, considerando os dados reais de precipitação e alturas d'água dos trabalhos de Machado e Silva. A partir de então se iniciaram as simulações referentes aos riscos analisados neste estudo que foram os usuais em drenagem urbana que são 5, 10, 25 e 50 anos de período de retorno (TR). Para os parâmetros de entrada do modelo com os valores ajustados para os dados medidos por Silva, foram usados os quatros períodos de retorno, pois os dados medidos no trabalho dela são mais atuais em relação aos dados medidos por Machado.

Para os parâmetros de entrada do modelo ajustados com os dados medidos de Machado, foram simulados hidrogramas de cheia com um período de retorno 25 e 50 anos, devido aos dados terem sido medidos em 1980, há 23 anos atrás, então para se fazer previsões futuras utilizou-se estes períodos de retorno e 2 horas de duração de chuva.

As Figuras 51, 52, 53 e 54 mostram a comparação dos três hidrogramas obtidos através das simulações, para um período de retorno de 5, 10, 25 e 50 anos e 2 horas de 
duração de chuva. Nas Figuras 55 e 56 está apresentada a comparação entre os três hidrogramas gerados pelas simulações, para um período de retorno de 25 e 50 anos.

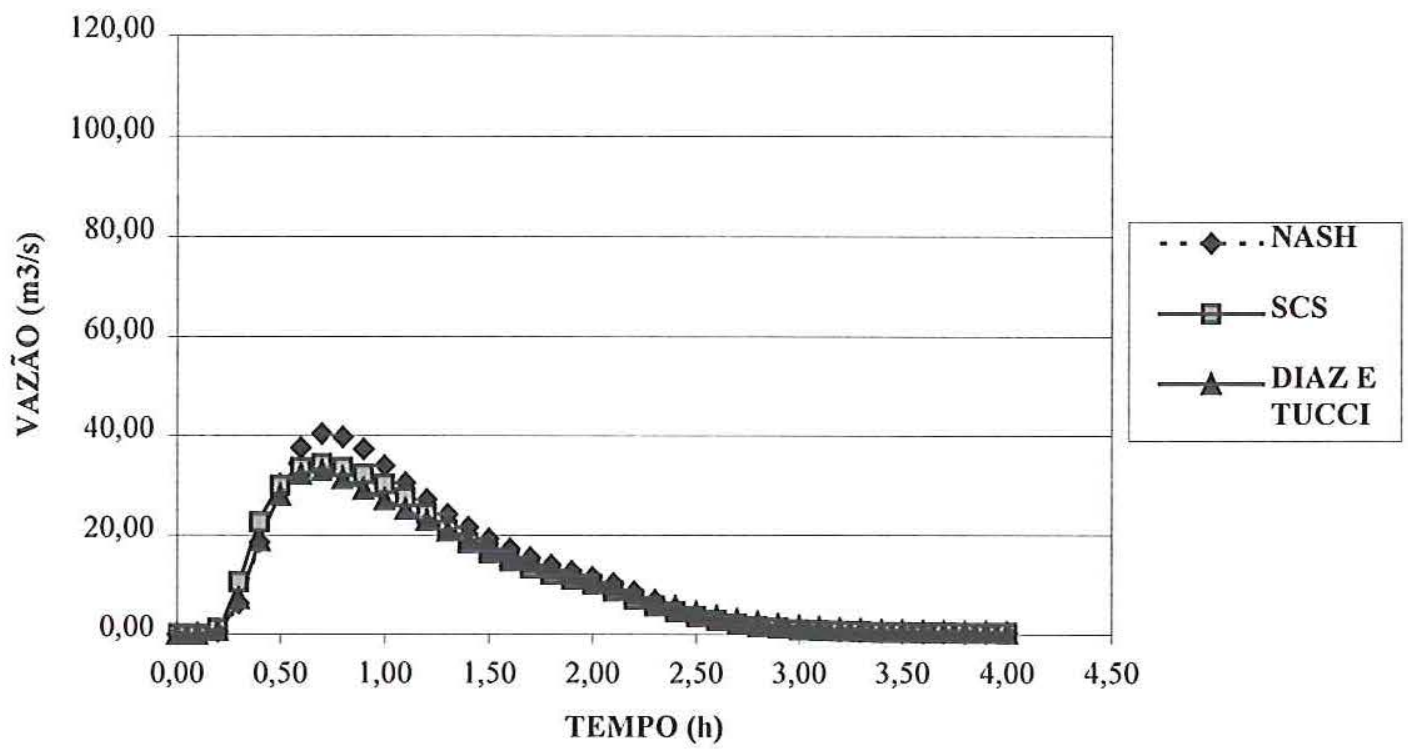

Figura 51 - Hidrogramas calculados para a seção do Fórum, com TR = 5 anos.

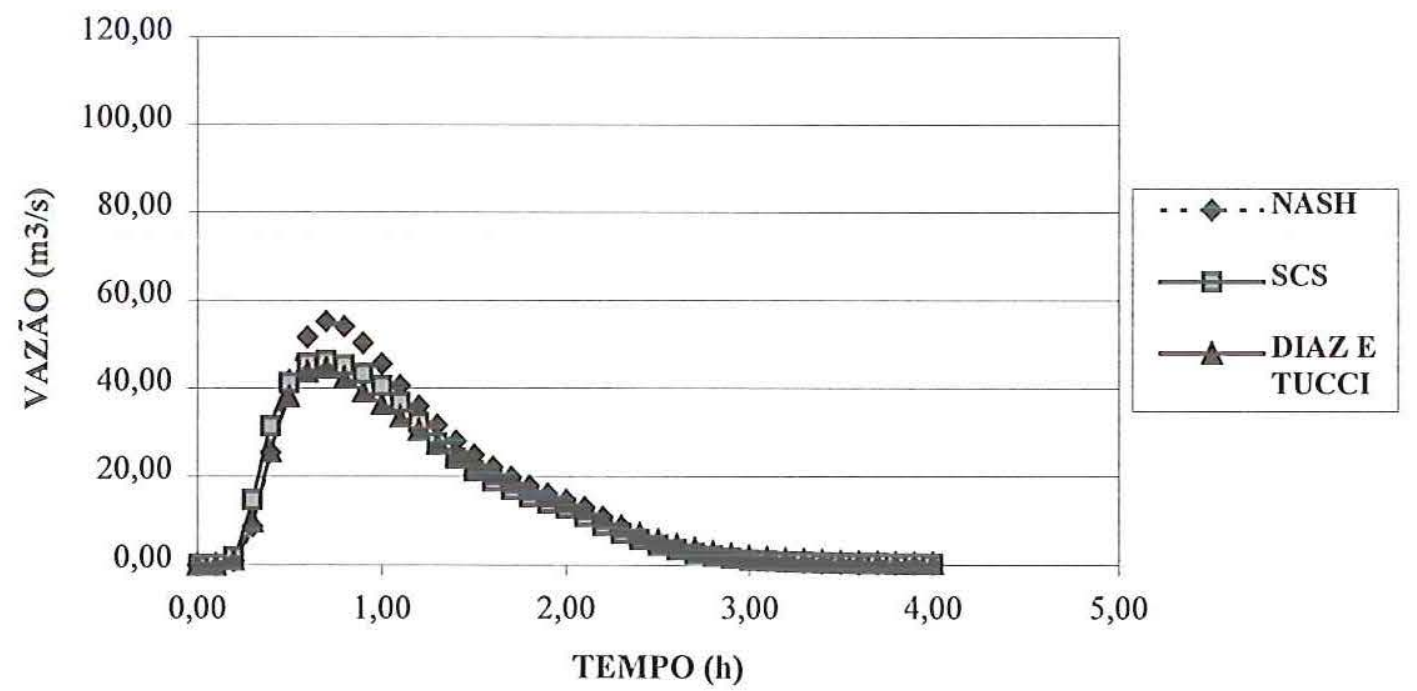

Figura 52 - Hidrogramas calculados para a seção do Fórum, com TR = 10 anos. 


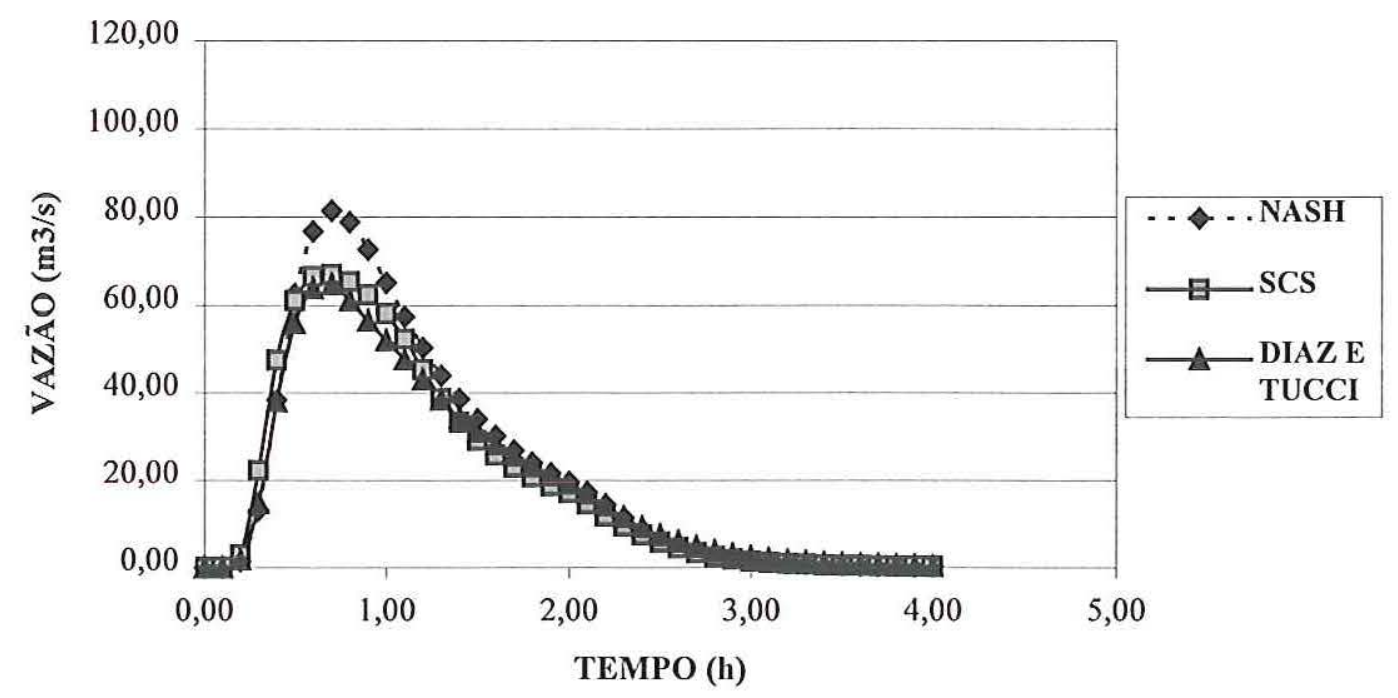

Figura 53 - Hidrogramas calculados para a seção do Fórum, com TR = 25 anos.

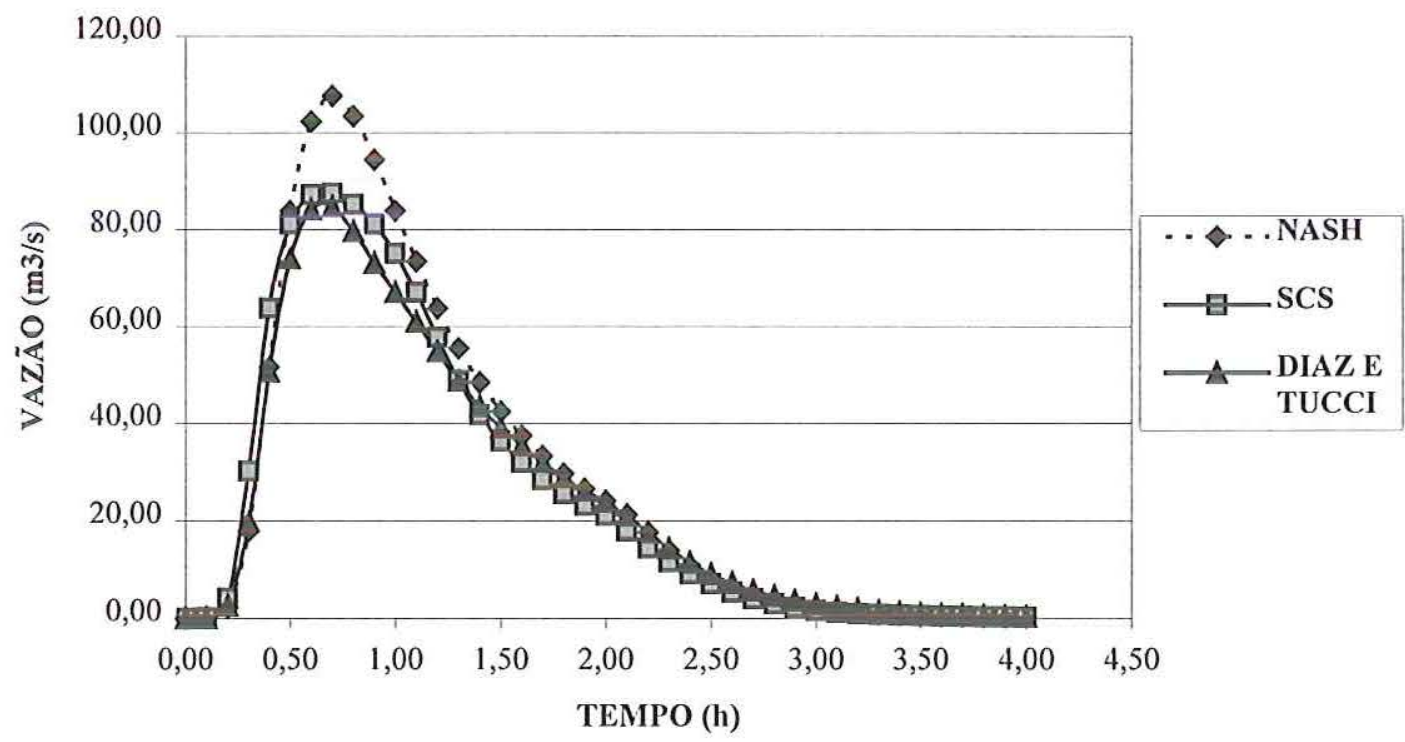

Figura 54 - Hidrogramas calculados para a seção do Fórum, com TR = 50 anos. 


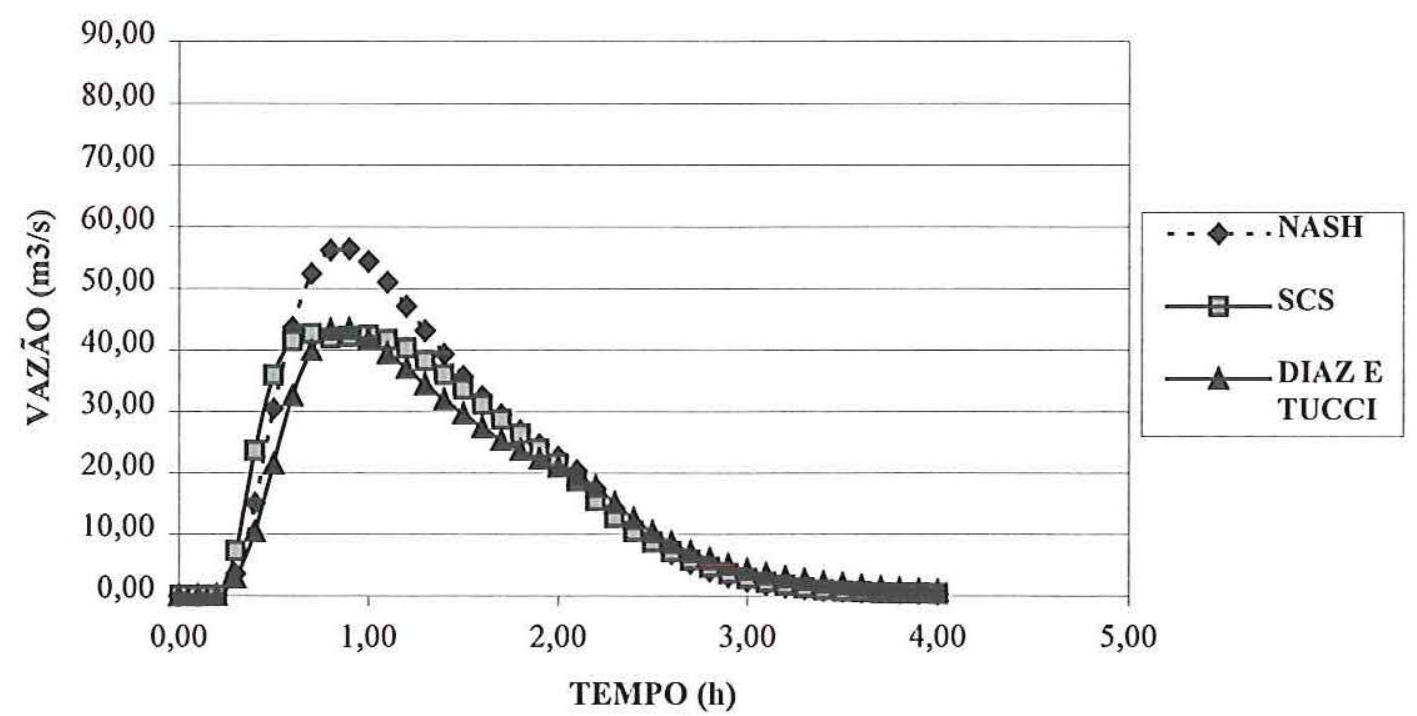

Figura 55 - Hidrogramas calculados para a seção do Mercado Municipal, com $\mathrm{TR}=25$ anos.

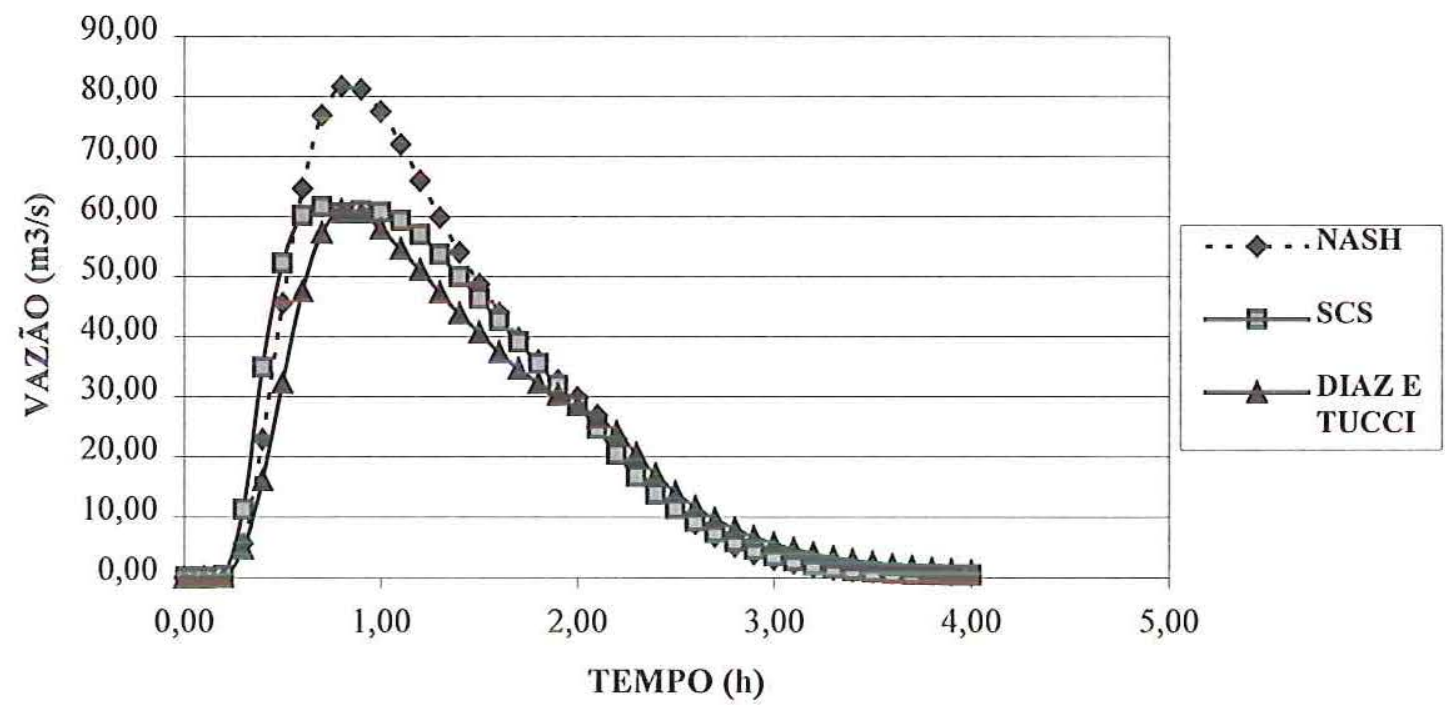

Figura 56 - Hidrogramas calculados para a seção do Mercado Municipal, com $\mathrm{TR}=50$ anos.

Através da análise dos resultados das simulações para verificação do modelo, é possível observar que mais uma vez o hidrograma gerado pelo método de Nash ficou mais elevado em relação ao do SCS e ao de Diaz e Tucci, esta verificação serve para as simulações na seção do Fórum e na seção do Mercado Municipal.

Como no item 5.4.3 já se fez a análise e comparação com os dois hidrogramas 
observados nas respectivas seções, então ficou decidido que os melhores métodos para obtenção de hidrogramas unitários são os métodos do SCS e o de Diaz e Tucci. As tabelas 23 e 24 contêm os valores obtidos através das simulações das vazões de pico para um determinado tempo, a Tabela 23 apresenta os valores referentes às Figuras 51, 52, 53 e 54 e a Tabela 24 informa os resultados em relação às Figuras 55 e 56.

Tabela 23 - Valores da vazão de pico associado ao tempo para os três métodos, na seção do Fórum.

\begin{tabular}{|c|c|c|c|c|}
\hline \multirow{2}{*}{ Método } & \multicolumn{2}{|c|}{ Figura 51 } & \multicolumn{2}{c|}{ Figura 52 } \\
\cline { 2 - 5 } & $\begin{array}{c}\text { Vazão de Pico } \\
\left(\mathbf{m}^{\mathbf{3}} / \mathbf{s}\right)\end{array}$ & $\begin{array}{c}\text { Tempo } \\
\text { (h) }\end{array}$ & $\begin{array}{c}\text { Vazão de Pico } \\
\left(\mathbf{m}^{\mathbf{3}} / \mathbf{s}\right)\end{array}$ & $\begin{array}{c}\text { Tempo } \\
\text { (h) }\end{array}$ \\
\hline NASH & 40,42 & 070 & 55,16 & 0,70 \\
\hline SCS & 34,30 & 0,70 & 46,14 & 0,70 \\
\hline DIAZ E TUCCI & 32,98 & 0,70 & 44,44 & 0,70 \\
\hline \multirow{2}{*}{ Método } & \multicolumn{2}{|c|}{ Figura 53 } & \multicolumn{2}{c|}{ Figura 54 } \\
\cline { 2 - 6 } & $\begin{array}{c}\text { Vazão de Pico } \\
\left(\mathbf{m}^{3} / \mathbf{s}\right)\end{array}$ & $\begin{array}{c}\text { Tempo } \\
(\mathbf{h})\end{array}$ & $\begin{array}{c}\text { Vazão de Pico } \\
\left(\mathbf{m}^{3} / \mathbf{s}\right)\end{array}$ & $\begin{array}{c}\text { Tempo } \\
(\mathbf{h})\end{array}$ \\
\hline NASH & 81,44 & 0,70 & 107,64 & 0,70 \\
\hline SCS & 66,97 & 0,70 & 87,55 & 0,70 \\
\hline DIAZ E TUCCI & 64,73 & 0,70 & 84,80 & 0,70 \\
\hline
\end{tabular}

Tabela 24 - Valores da vazão de pico associado ao tempo para os três métodos, na seção do Mercado Municipal.

\begin{tabular}{|c|c|c|c|c|}
\hline \multirow{2}{*}{ Método } & \multicolumn{2}{|c|}{ Figura 55 } & \multicolumn{2}{c|}{ Figura 56 } \\
\cline { 2 - 5 } & $\begin{array}{c}\text { Vazão de Pico } \\
\left(\mathbf{m}^{\mathbf{3}} / \mathbf{s}\right)\end{array}$ & $\begin{array}{c}\text { Tempo } \\
(\mathbf{h})\end{array}$ & $\begin{array}{c}\text { Vazão de Pico } \\
\left(\mathbf{m}^{\mathbf{3}} / \mathbf{s}\right)\end{array}$ & $\begin{array}{c}\text { Tempo } \\
(\mathbf{h})\end{array}$ \\
\hline NASH & 56,44 & 0,90 & 81,74 & 0,80 \\
\hline SCS & 42,66 & 0,70 & 61,63 & 0,70 \\
\hline DIAZ E TUCCI & 43,40 & 0,90 & 61,06 & 0,80 \\
\hline
\end{tabular}




\section{CONCLUSÕES E RECOMENDAÇÕES}

\subsection{Conclusões}

Foi aprimorado um modelo matemático de simulação chuva-vazão para bacias urbanas e rurais, com aplicação ao sistema de macrodrenagem da cidade de São Carlos.

As análises efetuadas em diversas sub-bacias e seções do sistema, com a discretização inicial e com a nova discretização incluindo as apresentadas neste trabalho, permitem concluir que para as bacias rurais ou com pouca urbanização, a subbacia 41 apresentada no item 5.3, o método de Nash gerou vazões de pico relativamente maiores que os outros dois métodos. A média da comparação deste aumento entre o método de Nash com o de Diaz e Tucci e o do SCS ficou na ordem de $27 \%$.

Para as bacias com alto grau de urbanização, como a sub-bacia 49, a diferença entre a vazão de pico do método de Nash com os métodos do SCS e de Diaz e Tucci, também apresentou uma elevada diferença, em torno de $25 \%$.

A diferença entre as vazões de pico dos métodos do SCS e o de Diaz e Tucci para a sub-bacia 41 foi pequena, na ordem de $13 \%$. Já para a sub-bacia 49 , os dois métodos apresentaram suas vazões de pico muito próximas, em torno de $3 \%$.

A partir das comparações dos valores das vazões de pico entre os três métodos, observou-se que os percentuais calculados ficaram maiores entre o método de Nash com o do SCS e entre o método de Nash e o de regionalização de Diaz e Tucci, pois em todas as simulações o pico dos hidrogramas gerados pelo método do SCS e o de Diaz e Tucci teve seus valores muito próximos, ficando a porcentagem entre eles menores do que com o pico obtido pelo método de Nash.

Apenas para a sub-bacia 41 que é muito plana e relativamente grande, antes da nova discretização, o método de Nash produziu um hidrograma com vazão de pico menor e tempo de pico maior, em relação à sub-bacia 49 que mostra através da Tabela 
17 no item 5.3, o oposto ao apresentado para a sub-bacia 41 na Tabela 16 , no mesmo item.

Com a nova discretização, ou seja, com a divisão das sub-bacias 41 e 49 as simulações realizadas nas seções 6.2 e 8.2 que inclui toda a área considerada para as duas sub-bacias na discretização inicial, as simulações realizadas para estas seções apresentaram para os três métodos vazões de pico menores e tempos de pico maiores, com exceção do método do SCS que gerou vazão de pico maior e tempo de pico menor, quando este tempo não permaneceu o mesmo. Esta análise pode ser observada através da Tabelas 16 e 17 do item 5.3.

Também foram simuladas vazões no exutório final da rede de macrodrenagem da cidade de São Carlos, especificado pela seção 7.2 (discretização inicial) e 11.2 (nova discretização) para se obter a influência na vazão com a criação de mais duas subbacias, e através da Tabela 18, item 5.3, mostra os valores obtidos para as vazões geradas pelos três métodos e observa-se que as vazões de pico aumentaram e os tempos de pico permaneceram o mesmo ou diminuíram.

Além disso, foram feitas várias simulações para se saber o grau de influência do número de deflúvio $(\mathrm{N})$ e do grau de vegetação (PP), na obtenção dos hidrogramas de cheia pelos três métodos e concluiu-se que o $\mathrm{N}$ interfere muito mais no valor da vazão de pico do que o PP. Algumas simulações para a verificação desta influência do $\mathrm{N}$ e do PP na vazão de pico, podem ser verificadas nas Figuras 34, 35, 36 e 37 que apresentam os hidrogramas de cheia e nas Tabelas 19 e 20 estão os valores obtidos.

Para apresentar claramente a influência do $\mathrm{N}$ resolveu-se fazer uma relação entre o $\mathrm{N}$ e a vazão de pico para valores de $\mathrm{N}$ que variaram entre 65 e 95, e quanto maior o valor determinado para este parâmetro maior será a vazão. As Figuras 38, 39 e 40 mostram graficamente esta relação.

Em todas as simulações realizadas e apresentadas neste trabalho pode-se verificar que pela análise e comparação feita para os hidrogramas de cheia entre os três métodos, chegou-se à conclusão que o hidrograma gerado pelo método de Nash está superestimado em relação ao obtido pelos outros métodos. Os métodos do SCS e de Diaz e Tucci apresentaram hidrogramas bastante parecidos, ou seja, a vazão de pico entre os dois para qualquer simulação está bastante próxima.

Este trabalho necessitou de dados medidos para dar credibilidade ao que se está afirmando no parágrafo acima, pois como não estava previsto nos objetivos iniciais deste estudo, foi preciso obter dados medidos de outros trabalhos já apresentados e se 
fazer a comparação entre um hidrograma observado e os gerados pelos três métodos para alguma seção pertencente à bacia considerada no estudo.

O Hidrograma Observado foi obtido através dos trabalhos de Machado (1981) e Silva (2003), que disponibilizaram de dados medidos para a obtenção da curva-chave e conseqüentemente do hidrograma observado.

Do trabalho de Machado não se teve problema com o hidrograma observado, pois a análise feita com os dados obtidos para a curva-chave dele não apresentou falha alguma. Já o trabalho de Silva, a seção utilizada por ela para gerar a curva-chave não foi adequada para o local onde os dados foram medidos e para isso através da seção correta que faz parte deste estudo, calcularam-se três vazões pela equação de Manning, considerando 0,025 para o coeficiente de rugosidade, e em relação às alturas d'água medidas por ela se obteve a nova curva-chave utilizada neste trabalho.

As comparações foram feitas nas Figuras 49 e 50, em que esta mostra o hidrograma observado 1 e os calculados pelos três métodos na seção do Mercado Municipal e aquela apresenta o hidrograma observado 2 e calculados através dos três métodos, na seção do Fórum. Pode-se observar entre as figuras que realmente o método de Nash está superdimensionado em relação aos outros dois métodos, a vazão pico obtida está bem maior e por isso, chegou-se à conclusão que os métodos do SCS e o de Diaz e Tucci são mais confiáveis na geração de hidrogramas unitários nas bacias urbanas.

As análises e comparações só puderam ser feitas em relação à vazão de pico, ao tempo de pico e a forma do hidrograma, e quanto ao volume do hidrograma nada se concluiu, pois os modelos usados por Silva e Machado incluem processos hidrológicos que o modelo EESC não simula, devido a isso as comparações em relação ao volume não foram realizadas.

\subsection{Recomendações}

Os diversos aspectos considerados no processo de planejamento de macrodrenagem, como construtivos, hidráulicos, ambientais, sociais, etc., a determinação da vazão de projeto, associadas a determinadas recorrências, é de fundamental importância, uma vez que seus valores definirão as diversas estruturas utilizadas para o controle das cheias. Grande parte dessas obras, devido às interferências 
com o meio urbano, possui uma complexidade construtiva e são geralmente muito dispendiosas.

A melhora dos resultados apresentados em relação ao hidrograma de projeto, ferramenta básica para o dimensionamento das estruturas de proteção, onde a maioria deles baseados na teoria do Hidrograma Unitário, só será possível a partir do momento que se faça um maior esforço para uma ação concreta de monitoramento de bacias urbanas para o levantamento de parâmetros e o uso de modelos matemáticos complexos para subsidiar o desenvolvimento de procedimentos de cálculo simples e práticos.

Propõe-se a criação de um comitê permanente para estudar e desenvolver tecnologia hidrológica e hidráulica, de cunho prático, em projetos e obras de drenagem urbana. Neste sentido sugere-se a integração ao problema de órgãos tais como: Departamento de Águas e Energia Elétrica (DAEE), Associação Brasileira de Normas Técnicas (ABNT), Associação Brasileira de Recursos Hídricos (ABRH), Institutos e Universidades.

Ao considerar a importância do problema e a necessidade de se gerar tecnologia adaptável às condições urbanas do país e passível de ser utilizada pelo corpo técnico de Prefeituras das cidades de médio porte, é necessário levantar a questão sobre o esforço da comunidade técnica, no sentido de se normalizar procedimentos práticos de cálculo, para a determinação das vazões de projeto em bacias urbanas.

É necessário o levantamento de perfil de seções e medições de velocidades, para que se possa obter uma curva-chave eficiente e segura para a obtenção de hidrogramas observados, que através da comparação e análise com os hidrogramas simulados irão dar maior credibilidade ao volume e forma destes hidrogramas e as vazões de picos geradas por eles.

Estudos futuros são recomendados para a atualização dos dados de entrada do sistema, para que haja uma maior confiabilidade no resultado do modelo e, além disso, inserir no modelo mais duas sub-rotinas, uma em relação à reservatórios de detenção e a outra, a utilização do equacionamento dinâmico que poderá ser considerado em todos os trechos ou em alguns trechos que tenham efeito de jusante.

Os trabalhos de modelagem relacionados ao impacto gerado pela construção desses reservatórios, implantados nos interiores dos lotes urbanos ou em sistemas de macrodrenagem, podem ser realizados com relativa simplicidade em conseqüência do padrão regular de representação da bacia hidrográfica, que poderá avaliar os impactos 
de obras destinadas à atenuação de enchentes urbanas, auxiliando o gerenciamento das águas pluviais.

Para melhor conhecimento do modelo aplicado neste trabalho urge que se façam testes de calibração em maior quantidade, nas sub-bacias consideradas neste estudo. No caso da Bacia do Gregório sugerem-se medidas de instrumentação como instalação de um pluviógrafo e um linígrafo, tanto na área rural como na área urbana. Além disso, fazer o levantamento de curvas-chave para as seções mais críticas da rede de macrodrenagem da cidade de São Carlos, para a obtenção de hidrogramas observados onde a partir desses se obtém uma análise e comparação mais confiável.

O sistema de macrodrenagem de São Carlos se encontra hoje em condições precárias de funcionamento devido às inundações, falta de manutenção de canalizações e com seções estranguladas inadequadas, que deve passar por um processo estrutural de vulto, acompanhado de medidas de uso e ocupação de solo para que esse sistema deixe de apresentar problemas para a cidade a curto e longo prazo.

Essa meta somente será alcançada através da vontade política da atual e futuras administrações, consubstanciadas em um Plano Diretor de grande alcance e de valor social na forma de lei. Nesse plano estaria definido o uso e ocupação do solo nas diversas regiões da área urbana, a sua expansão planejada e a compatibilidade dessa expansão urbana com a capacidade do sistema de drenagem.

Dentro dessa visão ampla de planejamento se inserem as recomendações quanto ao uso do solo, que deve ser dada uma atenção especial à ocupação urbanística das cabeceiras dos principais cursos de água, principalmente a do Córrego do Gregório que se encontra hoje em uma situação potencialmente perigosa, com relação a crescente impermeabilização. Se a ocupação dessa região se fizer de maneira natural, e ainda estimulada pela especulação imobiliária, a cidade estará condenada a conviver, definitivamente, com enchentes na sua região central, a despeito de vultosas intervenções estruturais.

Nesse aspecto, tanto as administrações municipais, quanto as forças políticas e da sociedade, têm grande responsabilidade com relação a esse problema e ao futuro da cidade.

As ações com relação à ocupação do solo nas cabeceiras do Córrego do Gregório devem se direcionar na garantia que o desenvolvimento dessa região não ultrapasse limites admissíveis para o grau de impermeabilização. Para isso, seria desejável a ocupação de uma grande área como Parque Municipal e, além disso, a exigência de um 
percentual alto de área verde nos lotes residenciais e industriais, que por ventura forem implementados nessa região.

Recomenda-se ainda a realização de um programa de manutenção preventiva da rede de canais, através da limpeza dos leitos atuais dos canais, incluindo remoção de vegetação de porte dos taludes, remoção de lixo e obstáculos e desassoreamento. 
ANEXO A - Temas estruturados dos debates para elaboração do Plano Diretor de São Carlos 


\section{Temas Estruturados dos Debates}

\section{Legislação}

1.1 Urbanística

- Municipal

- Estadual

- Federal: Lei 6766/79, Lei 4591/64, Constituição Federal de 1988, Estatuto da Cidade e Medida Provisória 2.220/2001

- Outras do âmbito municipal que tratam do espaço urbano, tais como: Código de Obras proposto, ambulantes, calçadas, limpeza de terrenos, antenas de telefonia celular, regularização de obras clandestinas, folhetos e panfletos, postos de combustível, invasão de área pública, mobiliário urbano, barreiras arquitetônicas, etc.

1.2 Ambiental

1.3 Rural

1.4 Patrimônio Histórico

2. Saneamento, Preservação e Recuperação Ambiental na Cidade e no Município

2.1 Gestão dos Recursos Naturais

- Mananciais e Recursos Hídricos

- Ar e Solo

2.2 Gestão da Cobertura Vegetal Rural e Urbana

2.3 Saneamento: Abastecimento de água e Coleta de Esgoto

2.4 Sistema de Drenagem Urbana

2.5 Manejo dos Resíduos Sólidos Domiciliares, Industriais, dos Serviços de Saúde e Entulhos

3. Territorialização das Atividades Econômicas

3.1 Desenvolvimento Regional 


\subsection{Desenvolvimento Rural}

3.3 Desenvolvimento Turístico Urbano e Rural

3.4 Desenvolvimento Urbano

- Comércio, Indústria e Serviços

- Distritos Industriais

- Pólo de Alta Tecnologia

4. Processo de Desenvolvimento Urbano

4.1 Vetores de expansão:

- Horizontal x Vertical

- Vazios x Adensamento

4.2 Uso e ocupação do solo:

- Definição do macrozoneamento - áreas de habitação de interesse social, áreas de proteção aos mananciais, áreas de interesse histórico e cultural, áreas de interesse ambiental, áreas industriais e outras

- Compatibilidade entre usos / ocupação

- Compatibilidade dos usos e ocupações com a capacidade (instalada e potencial) da infra-estrutura e dos equipamentos sociais

- Compatibilidade dos usos e ocupações com a capacidade de suporte dos recursos naturais (solo, água e flora)

4.3 Política de Recuperação e Valorização da Área Central

4.4 Política de Recuperação de Áreas Degradadas

4.5 Política de Mobilidade Sustentável 
ANEXO B - Relatório Pólis de São Carlos e Conferência da Cidade CD-ROM 
"CD-ROM DISPONÎVEL PARA EMPRÉSTTMO NO BALCÃO DE ATENDTMENTO。" 
ANEXO C - Rede de macrodrenagem de São Carlos - Sem modificações 


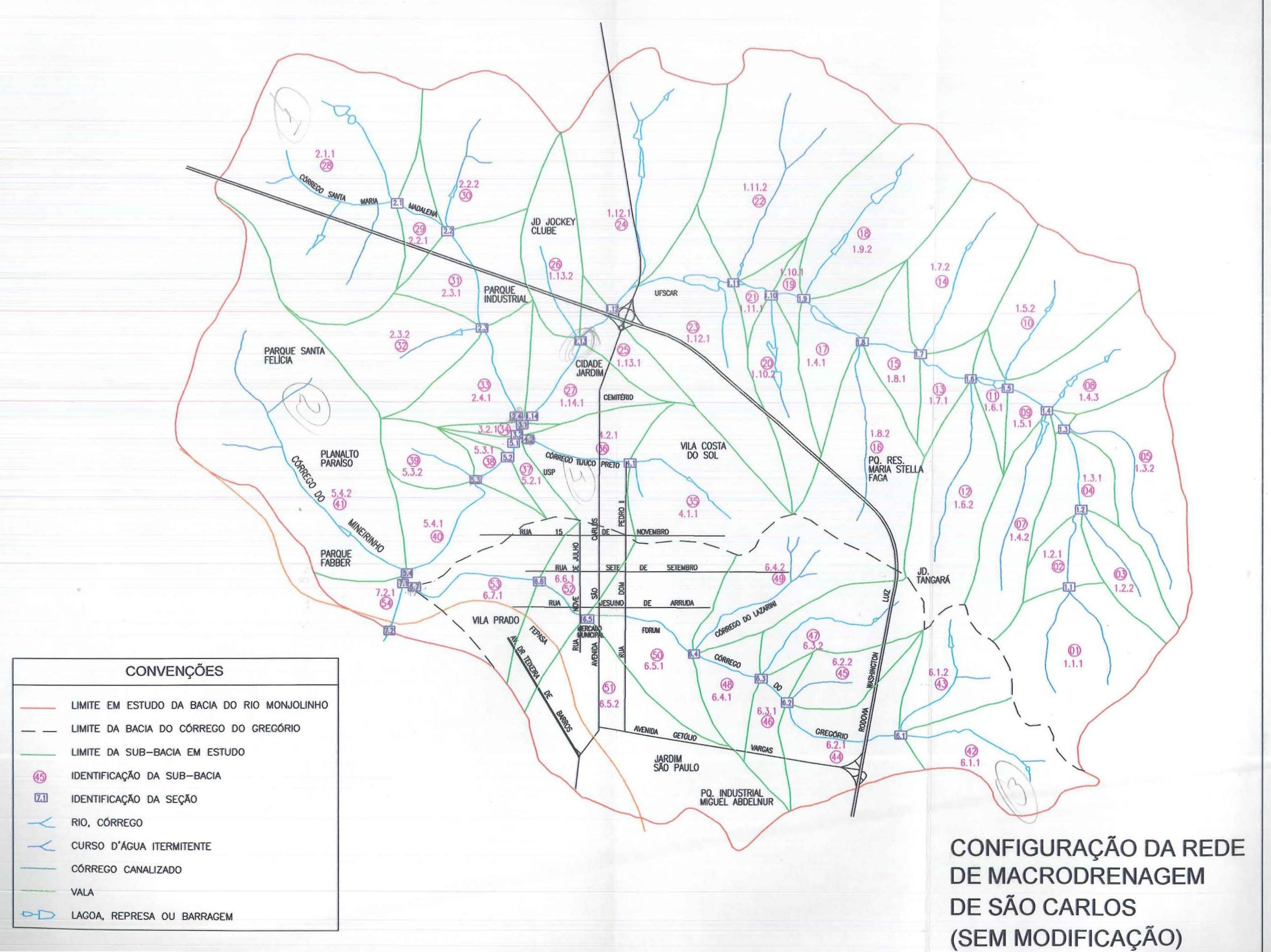


ANEXO D - Rede de macrodrenagem de São Carlos - Com modificações 


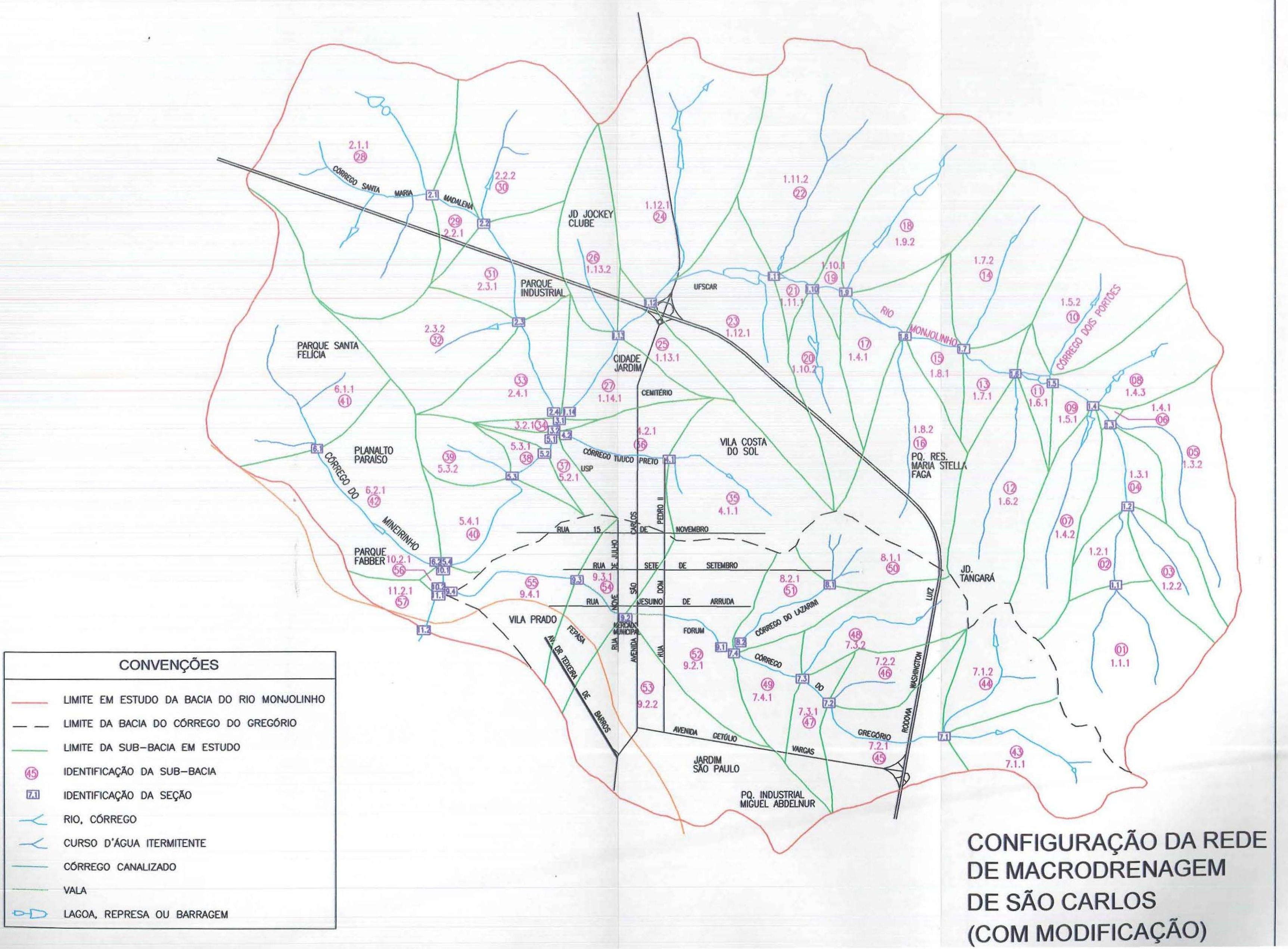


ANEXO E - Programa do modelo EESC - Subrotina Nash e subrotina Diaz e Tucci 


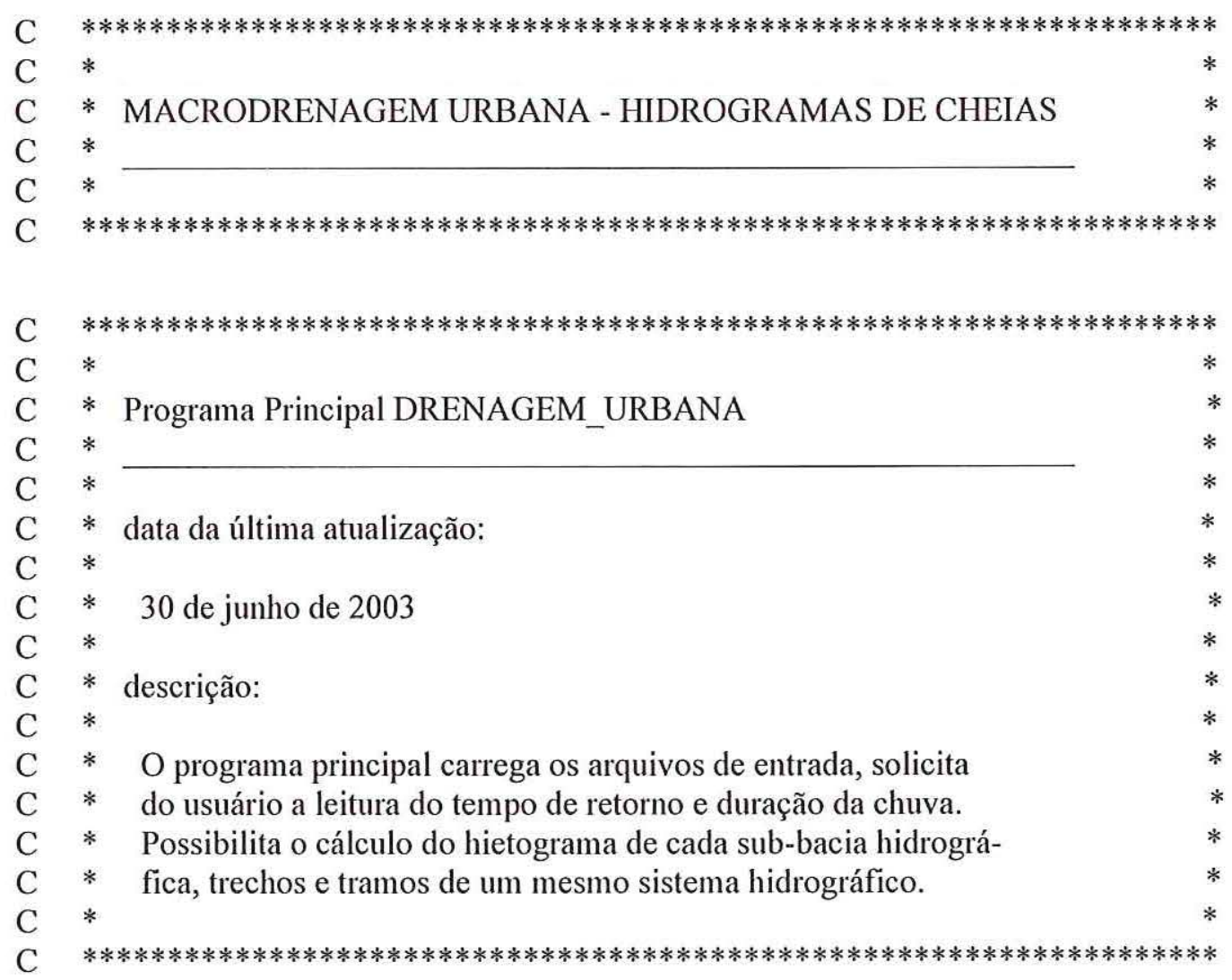

program drenagem_urbana

C definindo variáveis

REAL N,L

COMMON REARJ(100),QS(0:100,0:100),KTC

DIMENSION NS(19),J1(19),J2(19),NSB(17,15),NNSA(17,25,3), QO(500), Q1(500)

*,Q(17,100),ALF(17,20),BET(17,20),DDX(17,20),DELR(100),H(0:100),R(0:100),T(0:500)

$\mathrm{C}$ Abre o arquivo de dados DREDADB.TXT

OPEN (UNIT=1,STATUS='OLD',FILE='DREDADB.DAT',FORM='FORMATTED')

C Abre o arquivo de dados CHUVADA.TXT

OPEN (UNIT=2,STATUS='OLD',FILE='CHUVADA.DAT',FORM='FORMATTED')

C Abre o arquivo de dados SUBDADB.TXT OPEN $($ UNIT=4,STATUS='OLD',FILE='SUBDADB.DAT',FORM='FORMATTED')

C Abre 0 arquivo de dados TREDADB.TXT OPEN $($ UNIT $=5$,STATUS='OLD',FILE='TREDADB.DAT',FORM='FORMATTED')

C Número de intervalos de tempo igual a $\mathbf{4 0}$

934 NTEMP $=40$

C Entrada de dados pelo teclado: período de retorno em anos WRITE $\left(6,{ }^{*}\right)^{\prime}$ PERIODO DE RETORNO,EM ANOS =' 
$\operatorname{READ}\left(0,{ }^{*}\right) \mathrm{TR}$

C Entrada de dados pelo teclado: duração da chuva em horas WRITE $\left(6,{ }^{*}\right)^{\prime}$ DURACAO DA CHUVA, EM HORAS =' $\operatorname{READ}\left(0,{ }^{*}\right) \mathrm{DC}$

C Cálculo do intervalo de tempo em horas $\mathrm{D}=\mathrm{DC} / \mathrm{FLOAT}(20)+0.00000001$

C Lê os parâmetros da equação intensidade-duração-frequência

C do arquivo de dados CHUVADA.TXT $\operatorname{READ}\left(2,{ }^{*}\right) \mathrm{XK}, \mathrm{B}, \mathrm{C}, \mathrm{T} 0$

C WRITE(6,300)TR,DC,D,XK,B,C,T0

$\mathrm{KT}=\mathrm{NTEMP}$

QBASE $=0.01$

$\mathrm{DT}=\mathrm{D} * 3600$.

$\mathrm{T}(0)=0$.

DO $711 \mathrm{~J}=1$,NTEMP

$T(J)=F L O A T(J) * D * 60$.

$\mathrm{QO}(\mathrm{J})=\mathrm{QBASE}$

$\mathrm{Q} 1(\mathrm{~J})=\mathrm{QBASE}$

711 CONTINUE

C.....CÁlCULO DO HIETOGRAMA DE PROJETO.

$\mathrm{H}(0)=0$.

$\mathrm{KTC}=\mathrm{INT}(\mathrm{DC} / \mathrm{D}+0.001)$

IF(DC.LE.2.001) THEN

DO $500 \mathrm{~J}=0, \mathrm{KTC}$

$\mathrm{H}(\mathrm{J})=(\mathrm{XK} * \mathrm{TR} * \mathrm{~B}) /((\mathrm{T}(\mathrm{J})+\mathrm{T} 0) * * \mathrm{C})$

$R(J)=H(J) * D * F L O A T(J)$

500 CONTINUE

DO $501 \mathrm{~J}=0, \mathrm{KTC}$

$\operatorname{DELR}(\mathrm{J}+1)=\mathrm{R}(\mathrm{J}+1)-\mathrm{R}(\mathrm{J})$

501 CONTINUE

$\operatorname{REARJ}(1)=\operatorname{DELR}(6)$

$\operatorname{REARJ}(2)=\operatorname{DELR}(3)$

$\operatorname{REARJ}(3)=\operatorname{DELR}(1)$

$\operatorname{REARJ}(4)=\operatorname{DELR}(2)$

$\operatorname{REARJ}(5)=\operatorname{DELR}(4)$ 
$\operatorname{REARJ}(6)=\operatorname{DELR}(5)$

DO $302 \mathrm{~J}=7, \mathrm{KTC}$

$\operatorname{REARJ}(\mathrm{J})=\operatorname{DELR}(\mathrm{J})$

302 CONTINUE

ELSE

$\mathrm{HINT}=\left(\mathrm{XK}^{*} \mathrm{TR} * * \mathrm{~B}\right) /\left((\mathrm{DC} * 60 .+\mathrm{T} 0) * \mathrm{C}^{*}\right)$

DO $502 \mathrm{~J}=0, \mathrm{KTC}$

$\operatorname{REARJ}(\mathrm{J}+1)=\mathrm{HINT} * \mathrm{D}$

502 CONTINUE

END IF

HCHUV $=0$.

DO $924 \mathrm{j}=1, \mathrm{ktc}$

$924 \quad \mathrm{HCHUV}=\operatorname{rearj}(\mathrm{j})+\mathrm{HCHUV}$

DO $724 \mathrm{~K}=1, \mathrm{KT}$

$\mathrm{T}(\mathrm{K})=\mathrm{D} * \mathrm{FLOAT}(\mathrm{K})+0.000001$

724 CONTINUE

C.....DADOS DE ENTRADA DA CONFIGURAÇÃO DA REDE DE DRENAGEM..........

C Lê o número de tramos da rede de canais principais do arquivo

C de dados DREDADB.TXT $\operatorname{READ}\left(1,{ }^{*}\right) \mathrm{NTR}$

C WRITE(6,100)NTR

C Lê o número de seções por tramo do arquivo de dados DREDADB.TXT $\operatorname{READ}\left(1,{ }^{*}\right)(\mathrm{NS}(\mathrm{NT}), \mathrm{NT}=1, \mathrm{NTR})$

C WRITE(6,100)(NS(NT),NT=1,NTR)

C Lê dois possíveis "tramos de montante" conectados diretamente com

C o tramo NT do arquivo de dados DREDADB.TXT $\operatorname{READ}\left(1,{ }^{*}\right)(\mathrm{J} 1(\mathrm{NT}), \mathrm{J} 2(\mathrm{NT}), \mathrm{NT}=1, \mathrm{NTR})$

C WRITE(6,100)(J1(NT),J2(NT),NT=1,NTR) $\mathrm{JJ}=0$ DO $102 \mathrm{NT}=1, \mathrm{NTR}$ $\mathrm{IAUX}=\mathrm{NS}(\mathrm{NT})$

$\operatorname{READ}\left(1,{ }^{*}\right)(\mathrm{NSB}(\mathrm{NT}, \mathrm{I}), \mathrm{I}=1, \mathrm{IAUX})$

C WRITE(6,100)(NSB(NT,I),I=1,IAUX)

DO $104 \mathrm{I}=1$,IAUX

$\mathrm{IAUX} 1=\mathrm{NSB}(\mathrm{NT}, \mathrm{I})$ 


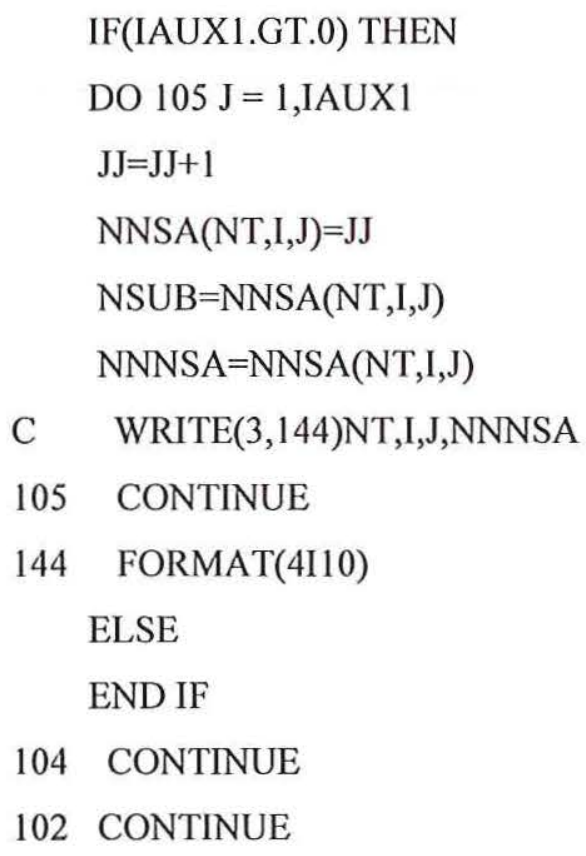


C Entrada de dados pelo teclado: deseja alterar alguns valores de alfa

C e beta de trechos da rede de canais? Se "sim" tecle 1, se "não" tecle 0 WRITE $\left(6,{ }^{*}\right)^{\prime}$ DESEJA ALTERAR ALGUNS VALORES DE ALFA E BETA DE *TRECHOS DA REDE DE CANAIS? (SIM)1 (NAO)0'

C Lê NALT - número para alteração, se NALT igual a 1 então, a pergunta

C a seguir é feita

$\operatorname{READ}\left(0,{ }^{*}\right) \mathrm{NALT}$

IF(NALT.EQ.1)THEN

C Entrada de dados pelo teclado: quantos trechos?

WRITE $\left(6,{ }^{*}\right)^{\prime} \mathrm{QUANTOS}$ TRECHOS?'

$\operatorname{READ}\left(0,{ }^{*}\right) \mathrm{NTRAL}$

C Entrada de dados pelo teclado: fornecer os valores de alfa e beta, digitando:

C numero do tramo_numero do trecho_valor de alfa_valor de beta WRITE $\left(6,{ }^{*}\right)$ 'FORNECER OS VALORES DE ALFA E BETA, DIGITANDO : *NUMERO DO TRAMO_NUMERO DO TRECHO_VALOR DE ALFA_VALOR DE * BETA'

C Fazer ler o número de tramo (NT), o número de trecho (I), o valor de alfa (ALF)

C e valor de beta (BET) até a quantidade de trechos determinados (NTRAL) DO 445 IALT=1,NTRAL $\operatorname{READ}\left(0,{ }^{*}\right) \mathrm{NT}, \mathrm{I}, \mathrm{ALF}(\mathrm{NT}, \mathrm{I}), \mathrm{BET}(\mathrm{NT}, \mathrm{I})$

445 CONTINUE

ELSE

END IF

C Entrada de dados pelo telado: deseja alterar valor do coeficiente de deflúvio $\mathrm{N}$ e

C o grau de vegetação PP de alguma sub-bacia? Se "sim" tecle 1, se "não" tecle 0 WRITE(6,*)'DESEJA ALTERAR VALOR DO COEFICIENTE DE DEFLUVIO N E DO *GRAU DE VEGETACAO PP DE ALGUMA SUB-BACIA? (SIM)1 (NAO)0'

C Lê NSBAL - número da sub-bacia alterada, se NSBAL igual a 1 então, a pergunta

C a seguir é feita

$\operatorname{READ}\left(0,{ }^{*}\right) \mathrm{NSBAL}$ IF(NSBAL.EQ.1) THEN

C Entrada de dados pelo teclado: fornecer o número da sub-bacia_valor

C de $\mathrm{N}$ _valor de PP WRITE $\left(6,{ }^{*}\right)^{\prime}$ FORNECER O NUMERO DA SUB-BACIA_VALOR DE N_VALOR DE *PP'

C Lê o número da sub-bacia (IIISB), o valor de N (NALTT) e o valor de PP (PPALT) $\operatorname{READ}(0, *)$ IIISB,NALTT,PPALT 


\section{ELSE}

END IF

C $\quad$ ATOTA $=0$.

C Entrada de dados pelo teclado: Hidrograma de cheia desejado: se de uma sub-bacia

C tecle 1; se de uma seção da rede de canais, tecle 2 WRITE(6,*)' HIDROGRAMA DE CHEIA DESEJADO: SE DE UMA SUB-BACIA *TECLE 1; SE DE UMA SECAO DA REDE DE CANAIS, TECLE 2'

C Lê ITSAI - hidrograma de cheia de uma sub-bacia, se NSBAL igual a 1 então, a

C pergunta a seguir é feita $\operatorname{READ}(0, *)$ ITSAI IF (ITSAI.EQ.1) THEN

C Entrada de dados pelo teclado: tecle o número da sub-bacia WRITE(6,*)'TECLE O NUMERO DA SUB-BACIA'

C Lê o número da sub-bacia (NSBBS), senão $\operatorname{READ}(0, *) \mathrm{NSBBS}$ ELSE

C Entrada de dados pelo teclado: tecle o número do tramo, e o número da seção WRITE $\left(6,{ }^{*}\right)$ 'TECLE O NUMERO DO TRAMO, E O NUMERO DA SECAO'

C Lê o número do tramo (NTSAI) e o número da seção (NSAID) READ $(0, *)$ NTSAI,NSAID END IF ATOTA $=0$. DO 900 ISUB $=1$,NSUB

C Lê as variáveis do arquivo de dados SUBDAD.TXT (IISUB,N,L,PP,S,A) e alterar

C os valores de N e PP deste arquivo de dados por NALTT e PPALT, já determinados.

C Isto só será feito se NSBAL igual a 1 e IISUB igual a IIISUB.

READ $\left(4,{ }^{*}\right)$ IISUB,N,L,PP,S,A

IF(NSBAL.EQ.1) THEN

IF(IISUB.EQ.IIISB) THEN

$\mathrm{N}=\mathrm{NALTT}$

$\mathrm{PP}=$ PPALT

ELSE

END IF

ELSE

END IF

460 FORMAT(I10,5F 10.3)

C ATOTA=ATOTA + A 
C Início do código da sub-rotina SCS

CALL SCS(ISUB,N,L,PP,S,A,D)

IF(ITSAI.EQ.1)THEN

IF(ISUB.EQ.NSBBS)THEN

$\mathrm{ITR}=\mathrm{TR}$

C Apresentação na tela dos valores do hidrograma de cheia

$\operatorname{WRITE}\left(6,{ }^{*}\right)^{\prime}$

$* * * * * * * * * * * 1$

WRITE $(6, *)^{* * *}$ MACRO DRENAGEM DE SAO CARLOS-HIDROGRAMA DE CHEIA***1

WRITE(6,1001)ITR,DC,HCHUV,ISUB,N,PP

1001 FORMAT(/1X, 'TR=',I3,' anos',3X,'DC=',F4.2,' horas',3X,

*'CHUVA=', 44.1 ,'mm',3x,'SUB-BACIA=',I2,3X,'N='F4.0,3X,'PP=',F4.2)

WRITE $(6,1000)$

WRITE(6,666)(T(K),QS(ISUB,K),K=1,NTEMP)

WRITE $(6, *)^{\prime * * * * * * * * * * * * * * * * * * * * * * * * * * * * * * * * * * * * * * * * * * * * * * * * * * * * * * * * 1}$

$* * * * * * * * * * * 1$

$\operatorname{WRITE}\left(3,{ }^{*}\right)^{\prime * * * * * * * * * * * * * * * * * * * * * * * * * * * * * * * * * * * * * * * * * * * * * * * * * * * * * * * 1}$

$* * * * * * * * * * * 1$

WRITE $(3, *)^{\prime * * *}$ MACRO DRENAGEM DE SAO CARLOS-HIDROGRAMA DE CHEIA***1

WRITE(3,1001)ITR,DC,HCHUV,ISUB,N,PP

WRITE $(3,1000)$

WRITE(3,666)(T(K),QS(ISUB,K),K=1,NTEMP)

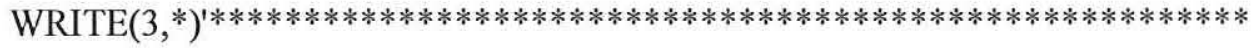

$* * * * * * * * * * * 1$

GO TO 933

ELSE

END IF

ELSE

END IF

C WRITE(6,666)(T(K),QS(ISUB,K),K=1,NTEMP)

C WRITE(3,671)ATOTA

C671 FORMAT(1X,'ATOTAL=',F10.3)

666 FORMAT(6F10.2)

900 CONTINUE

DO 1 NT $=1$,NTR 
$I A U X I=N S(N T)$

$\mathrm{IAUX} 2=\mathrm{J} 1(\mathrm{NT})$

$\mathrm{IAUX} 3=\mathrm{J} 2(\mathrm{NT})$

$\mathrm{I}=1$

IAUX4 $=$ NSB(NT,I)

IF(IAUX2.GT.0) THEN

INDIC $=2$

ELSE

INDIC $=1$

END IF

IF(IAUX3.GT.0) THEN

INDIC $=3$

ELSE

END IF

IF(IAUX4.EQ.3) THEN

$\mathrm{NSA} 1=\mathrm{NNSA}(\mathrm{NT}, \mathrm{I}, 1)$

NSA2 $=$ NNSA $(N T, I, 2)$

NSA3 $=$ NNSA $(N T, 1,3)$

DO $2 \mathrm{~K}=1$, KT

$2 \quad \mathrm{QO}(\mathrm{K})=\mathrm{QS}(\mathrm{NSA} 1, \mathrm{~K})+\mathrm{QS}(\mathrm{NSA}, \mathrm{K})+\mathrm{QS}(\mathrm{NSA} 3, \mathrm{~K})+\mathrm{QBASE}$

ELSE

IF(IAUX4.EQ.2) THEN

$\mathrm{NSA} 1=\mathrm{NNSA}(\mathrm{NT}, \mathrm{I}, 1)$

NSA2 $=$ NNSA $(N T, I, 2)$

DO $3 \mathrm{~K}=1$, KT

$3 \quad \mathrm{QO}(\mathrm{K})=\mathrm{QS}(\mathrm{NSA} 1, \mathrm{~K})+\mathrm{QS}(\mathrm{NSA} 2, \mathrm{~K})+\mathrm{QBASE}$

ELSE

IF(IAUX4.EQ.1) THEN

$\mathrm{NSA} 1=\mathrm{NNSA}(\mathrm{NT}, \mathrm{I}, 1)$

C WRITE(6,777)NSA1

C WRITE $(6,778)(\mathrm{QO}(\mathrm{K}), \mathrm{K}=1, \mathrm{KT})$

C777 FORMAT(1X,'NSAl=',I10)

C778 FORMAT(1X,'QO(K)=',F10.3)

DO $4 \mathrm{~K}=1, \mathrm{KT}$

$4 \quad \mathrm{QO}(\mathrm{K})=\mathrm{QS}(\mathrm{NSA} 1, \mathrm{~K})+\mathrm{QBASE}$

ELSE

DO $40 \mathrm{~K}=1, \mathrm{KT}$ 
40

$\mathrm{QO}(\mathrm{K})=\mathrm{QBASE}$

END IF

END IF

END IF

C WRITE(6,667)NT,INDIC

C667 FORMAT(1X,'NT,INDIC=',2I10)

IF(INDIC.EQ.3) THEN

DO $5 \mathrm{~K}=1, \mathrm{KT}$

$5 \quad \mathrm{QO}(\mathrm{K})=\mathrm{Q}(\mathrm{IAUX} 2, \mathrm{~K})+\mathrm{Q}(\mathrm{IAUX} 3, \mathrm{~K})$

ELSE

IF(INDIC.EQ.2) THEN

DO $6 \mathrm{~K}=1, \mathrm{KT}$

$6 \mathrm{QO}(\mathrm{K})=\mathrm{QO}(\mathrm{K})+\mathrm{Q}(\mathrm{IAUX} 2, \mathrm{~K})$

ELSE

END IF

END IF

IF(NT.EQ.NTSAI)THEN

IF(I.EQ.NSAID) THEN

$\mathrm{ITR}=\mathrm{TR}$

$\operatorname{WRITE}\left(6,{ }^{*}\right)^{\prime}$

WRITE $\left(6,{ }^{*}\right)^{1 * * *}$ MACRO DRENAGEM DE SAO CARLOS-HIDROGRAMA DE CHEIA***1

WRITE(6,9333)NT,I,ITR,DC,HCHUV

WRITE $(6,1000)$

WRITE(6,666)(T(K),QO(K),K=1,KT)

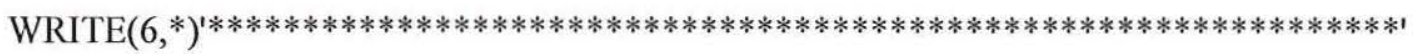

WRITE $\left(3,{ }^{*}\right)^{\prime * * * * * * * * * * * * * * * * * * * * * * * * * * * * * * * * * * * * * * * * * * * * * * * * * * * * * * * * * * * * * * * * 1}$

WRITE $\left(3,{ }^{*}\right)^{\prime * * *}$ MACRO DRENAGEM DE SAO CARLOS-HIDROGRAMA DE

CHEIA***1

WRITE(3,9333)NT,I,ITR,DC,HCHUV

WRITE $(3,1000)$

WRITE $(3,666)(\mathrm{T}(\mathrm{K}), \mathrm{QO}(\mathrm{K}), \mathrm{K}=1, \mathrm{KT})$

$\operatorname{WRITE}\left(3,{ }^{*}\right)^{\prime}$

GO TO 933

ELSE

END IF 
ELSE

END IF

9333 FORMAT(1X,'TRAMO=',I2,2x,'SECCAO=',I2,2X,'TR=',I3,'anos',2X,'DC= *',F4.2,'horas',2X,'CHUVA=',F4.1,'mm')

$$
\mathrm{ALFA}=\mathrm{ALF}(\mathrm{NT}, \mathrm{I}+1)
$$

$\mathrm{BETA}=\mathrm{BET}(\mathrm{NT}, \mathrm{I}+1)$

$\mathrm{DX}=\mathrm{DDX}(\mathrm{NT}, \mathrm{I}+1)$

C WRITE(3,30)(QO(K),K=1,KT)

C Início do código da sub-rotina PROPAG

CALL PROPAG(ALFA,BETA,DX,KT,DT,QO,Q1,QBASE)

DO 7 I $=2$,IAUX1

DO $8 \mathrm{~K}=1, \mathrm{KT}$

$\mathrm{QO}(\mathrm{K})=\mathrm{Q} 1(\mathrm{~K})$

C WRITE(6,669)K,QO(K)

C669 FORMAT(1X,'K,QO(K)=',I10,F10.3)

8 CONTINUE

IAUX4 $=$ NSB(NT,I)

IF(IAUX4.EQ.3) THEN

NSA $1=\mathrm{NNSA}(\mathrm{NT}, \mathrm{I}, 1)$

$\mathrm{NSA} 2=\mathrm{NNSA}(\mathrm{NT}, \mathrm{I}, 2)$

NSA $3=\mathrm{NNSA}(\mathrm{NT}, \mathrm{I}, 3)$

DO $10 \mathrm{~K}=1, \mathrm{KT}$

$10 \mathrm{QO}(\mathrm{K})=\mathrm{QO}(\mathrm{K})+\mathrm{QS}(\mathrm{NSA} 1, \mathrm{~K})+\mathrm{QS}(\mathrm{NSA} 2, \mathrm{~K})+\mathrm{QS}(\mathrm{NSA} 3, \mathrm{~K})+\mathrm{QBASE}$

ELSE

END IF

IF(IAUX4.EQ.2) THEN

$\mathrm{NSA} 1=\mathrm{NNSA}(\mathrm{NT}, \mathrm{I}, 1)$

NSA2 $=$ NNSA $(N T, I, 2)$

DO $11 \mathrm{~K}=1, \mathrm{KT}$

$11 \mathrm{QO}(\mathrm{K})=\mathrm{QO}(\mathrm{K})+\mathrm{QS}(\mathrm{NSA} 1, \mathrm{~K})+\mathrm{QS}(\mathrm{NSA} 2, \mathrm{~K})+\mathrm{QBASE}$

ELSE

END IF

IF(IAUX4.EQ.1) THEN

$\mathrm{NSA} 1=\mathrm{NNSA}(\mathrm{NT}, \mathrm{I}, 1)$

DO $44 \mathrm{~K}=1, \mathrm{KT}$

$44 \mathrm{QO}(\mathrm{K})=\mathrm{QO}(\mathrm{K})+\mathrm{QS}(\mathrm{NSA} 1, \mathrm{~K})+\mathrm{QBASE}$

ELSE 
DO $41 \mathrm{~K}=1, \mathrm{KT}$

$41 \quad \mathrm{QO}(\mathrm{K})=\mathrm{QO}(\mathrm{K})+\mathrm{QBASE}$

END IF

IF(NT.EQ.NTSAI)THEN

IF(I.EQ.NSAID) THEN

$\mathrm{ITR}=\mathrm{TR}$

WRITE $(6, *))^{\prime * * * * * * * * * * * * * * * * * * * * * * * * * * * * * * * * * * * * * * * * * * * * * * * * * * * * * * * * * * * * * * * 1}$

WRITE $\left(6,{ }^{*}\right)^{* * * * * * *}$ MACRO DRENAGEM DE SAO CARLOS-HIDROGRAMA DE

CHEIA $* * * * * * * * 1$

WRITE(6,9333)NT,I,ITR,DC,HCHUV

WRITE $(6,1000)$

1000 FORMAT(/,7x,'T(h)',4x,'Q(m3/s)',4x,'T(h)',4x,'Q(m3/s)',5x,'T(h)',

* $\left.\quad 4 \mathrm{x},{ }^{\prime} \mathrm{Q}(\mathrm{m} 3 / \mathrm{s})^{\prime} /\right)$

WRITE(6,666)(T(K),QO(K),K=1,KT)

WRITE $(6, *)^{\prime * * * * * * * * * * * * * * * * * * * * * * * * * * * * * * * * * * * * * * * * * * * * * * * * * * * * * * * * * * * * * * 1}$ WRITE $\left(3,{ }^{*}\right)^{\prime}$

WRITE $(3, *)^{\prime * * * * * *}$ MACRO DRENAGEM DE SAO CARLOS-HIDROGRAMA DE

CHEIA $* * * * * * * * 1$

WRITE(3,9333)NT,I,ITR,DC,HCHUV

WRITE $(3,1000)$

WRITE(3,666)(T(K),QO(K),K=1,KT)

WRITE $(3, *) 1 * * * * * * * * * * * * * * * * * * * * * * * * * * * * * * * * * * * * * * * * * * * * * * * * * * * * * * * * * * * * * * * 1$

GO TO 933

ELSE

END IF

ELSE

END IF

IF(I.LT.IAUX1) THEN

$\mathrm{ALFA}=\mathrm{ALF}(\mathrm{NT}, \mathrm{I}+1)$

$\mathrm{BETA}=\mathrm{BET}(\mathrm{NT}, \mathrm{I}+1)$

$\mathrm{DX}=\mathrm{DDX}(\mathrm{NT}, \mathrm{I}+1)$

CALL PROPAG(ALFA,BETA,DX,KT,DT,QO,Q1,QBASE)

ELSE

DO $411 \mathrm{~K}=1$, KT

$\mathrm{Q} 1(\mathrm{~K})=\mathrm{QO}(\mathrm{K})$

411 CONTINUE

END IF 
7 CONTINUE

DO $12 \mathrm{~K}=1, \mathrm{KT}$

$12 \mathrm{Q}(\mathrm{NT}, \mathrm{K})=\mathrm{Q} 1(\mathrm{~K})$

WRITE(3,301)NT

WRITE $(3,30)(\mathrm{Q}(\mathrm{NT}, \mathrm{K}), \mathrm{K}=1, \mathrm{KT})$

1 CONTINUE

30 FORMAT(5F 10.2$)$

100 FORMAT(6I10)

301 FORMAT(5I10)

300 FORMAT(4F10.3)

602 FORMAT(2I10,3F10.3)

933 CONTINUE

C Entrada de dados pelo teclado: deseja fazer nova simulação? se sim tecle 1,

C se não tecle 0

WRITE $\left(6,{ }^{*}\right)^{\prime}$ DESEJA FAZER NOVA SIMULACAO? (SIM)1 (NAO) $0^{\prime}$

C Lê NOVA

$\operatorname{READ}\left(0,{ }^{*}\right) \mathrm{NOVA}$

C Se NOVA igual a 1 então leia novamente UNIT $=1$, UNIT $=2$, UNIT $=4$ e UNIT $=5$,

C se não termina a simulação

IF(NOVA.EQ.1)THEN

REWIND 1

REWIND 2

REWIND 4

REWIND 5

GO TO 934

ELSE

END IF

END

C $\quad * * * * * * * * * * * * * * * * * * * * * * * * * * * * * * * * * * * * * * * * * * * * * * * * * * * * * * * * * * * * * * * * * * * * * * *$

C *

C * Fim do Programa PrinCipal DRENAGEM_URBANA *

$\mathrm{C} *$ * $*$

$\mathrm{C} * \overline{\mathrm{C}}=$ *

C $\quad * * * * * * * * * * * * * * * * * * * * * * * * * * * * * * * * * * * * * * * * * * * * * * * * * * * * * * * * * * * * * * * * * * * * * * *$ 


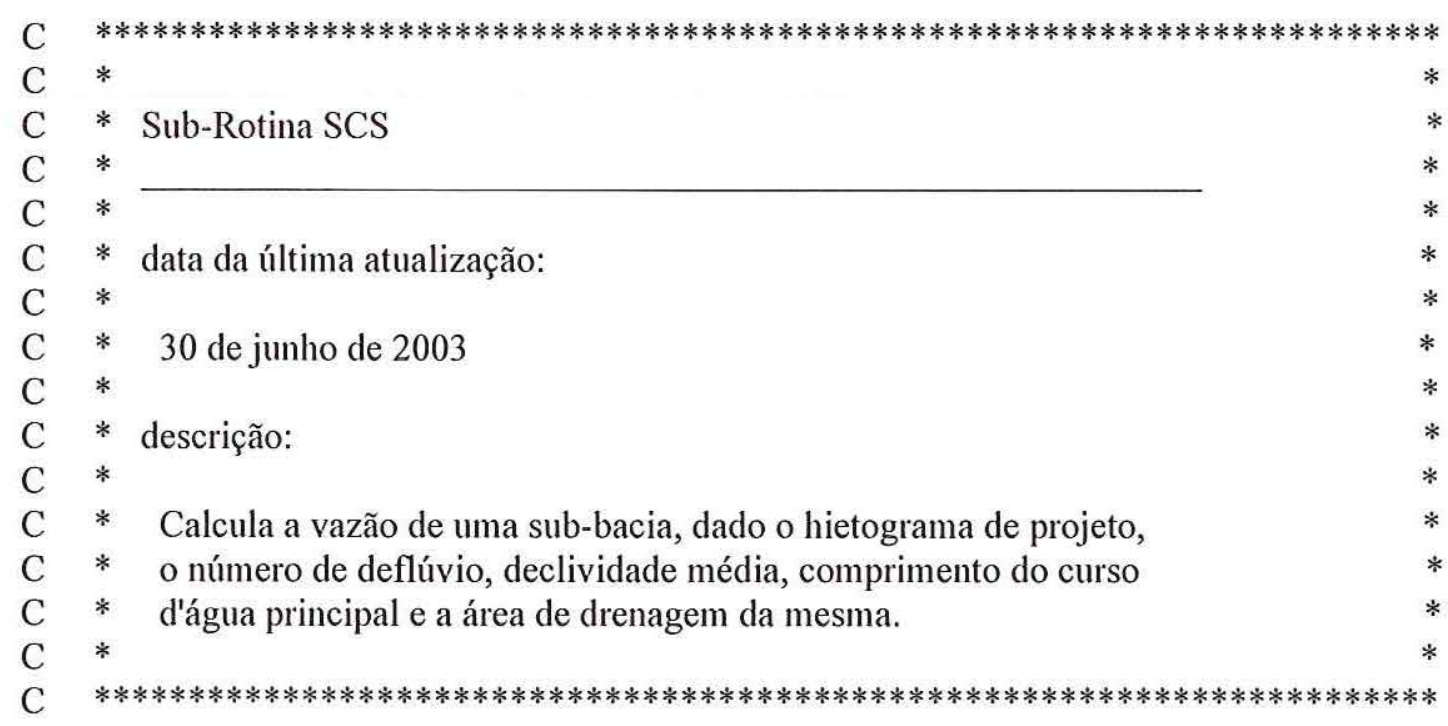

\section{SUBROUTINE SCS (NSAX,N,L,PP,S,A,D)}

C definindo variáveis da sub-rotina REAL N,L,KK

COMMON REARJ(100),QS(0:100,0:100),KTC

DIMENSION P(0:100),RE(0:100),T(500)

*,QU(0:100), KK(0:100),Q(0:100),O(0:100), RRE(0:100)

$\mathrm{KK}(0)=0$.

$\mathrm{QS}(\mathrm{NSAX}, 0)=0$.

C...........CÁlCULO DA CHUVA EFETIVA PELO MÉTODO SCS

$$
\mathrm{P}(0)=0 \text {. }
$$

DO $4 \mathrm{~J}=0, \mathrm{KTC}$

$\mathrm{P}(\mathrm{J}+1)=\operatorname{REARJ}(\mathrm{J}+1)+\mathrm{P}(\mathrm{J})$

$\operatorname{RE}(\mathrm{J})=(\mathrm{P}(\mathrm{J})-5080 / \mathrm{N}+50.8) * 2 /(\mathrm{P}(\mathrm{J})+20320 / \mathrm{N}-203.2)$

IF(P(J).LT.5080/N-50.8) THEN

$$
\mathrm{RE}(\mathrm{J})=0 \text {. }
$$

ELSE

END IF

4 CONTINUE 


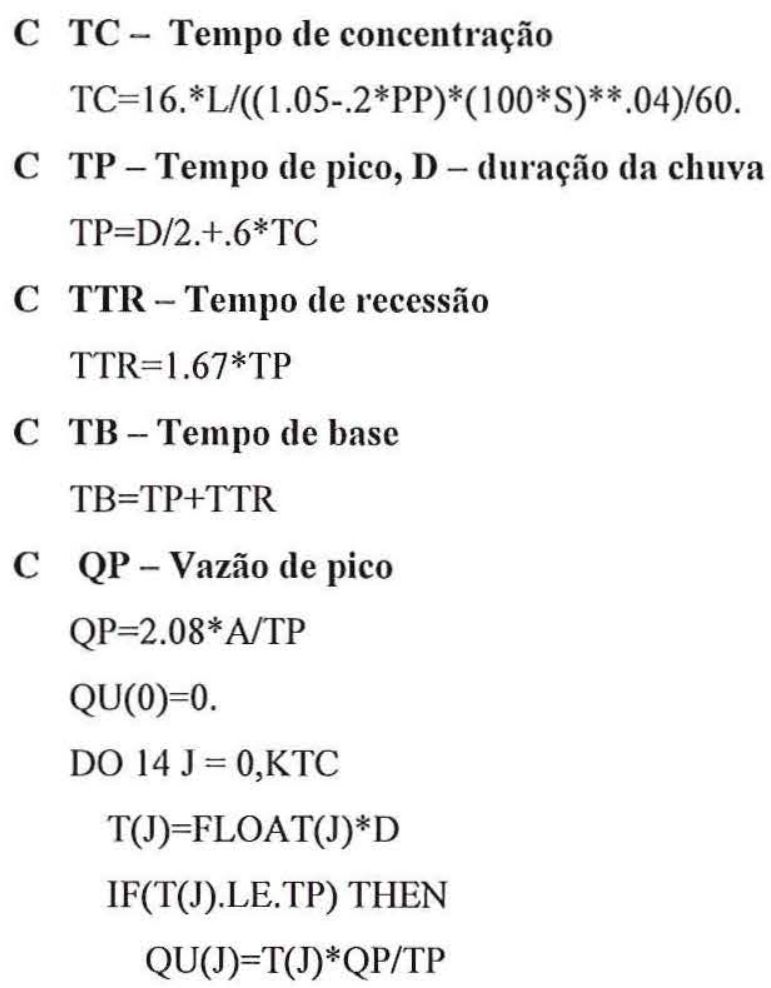

ELSE

IF(T(J).LE.TB) THEN

$\mathrm{QU}(\mathrm{J})=-\mathrm{QP} *(\mathrm{~T}(\mathrm{~J})-\mathrm{TB}) /(\mathrm{TB}-\mathrm{TP})$

ELSE

$\mathrm{QU}(\mathrm{J})=0$.

END IF

END IF

14 CONTINUE

DO $5 \mathrm{~J}=0, \mathrm{KTC}$

$\operatorname{RRE}(\mathrm{J}+1)=\operatorname{RE}(\mathrm{J}+1)-\operatorname{RE}(\mathrm{J})$

$\mathrm{Q}(\mathrm{J})=\mathrm{RRE}(\mathrm{J}) / 10$.

5 CONTINUE

C.........CONVOLUÇÃO DO HIDROGRAMA.

C convolução entre "hidrograma unitário triangular" e

C "escoamento superficial direto"

$\mathrm{OO}=0$.

$\mathrm{IBB}=1$

DO $6 \mathrm{JJ}=1,2 * \mathrm{KTC}$

$T(\mathrm{JJ})=F L O A T(J J) * D$

DO $7 \mathrm{~J}=1, \mathrm{JJ}$ 
$\mathrm{KL}=\mathrm{JJ}-\mathrm{J}+1$

IF(KL.LT.0) THEN

$\mathrm{KL}=0$

ELSE

END IF

$\mathrm{O}(\mathrm{JJ})=\mathrm{Q}(\mathrm{J}) * \mathrm{QU}(\mathrm{KL})$

$\mathrm{OO}=\mathrm{OO}+\mathrm{O}(\mathrm{JJ})$

7 CONTINUE

C WRITE(6,666)JJ,O(JJ)

C666 FORMAT(1X,'JJ,O(JJ)=',I10,F10.3)

$\mathrm{KK}(\mathrm{IBB})=\mathrm{OO}$

$\mathrm{IBB}=\mathrm{IBB}+1$

$\mathrm{OO}=0$.

6 CONTINUE

DO $200 \mathrm{~J}=1,2 * \mathrm{KTC}$

$200 \mathrm{QS}(\mathrm{NSAX}, \mathrm{J})=\mathrm{KK}(\mathrm{J})$

C WRITE( 3,111$)$ NSAX

C WRITE $(3,100)$ TC,TP

C WRITE(3,760)NSAX,N,L,PP,S,A

C WRITE $(3,100)(\mathrm{T}(\mathrm{J}), \mathrm{KK}(\mathrm{J}), \mathrm{J}=0,2 * \mathrm{KTC})$

100 FORMAT(6F 10.3)

111 FORMAT(I10)

760 FORMAT(I10,5F10.3)

RETURN

END

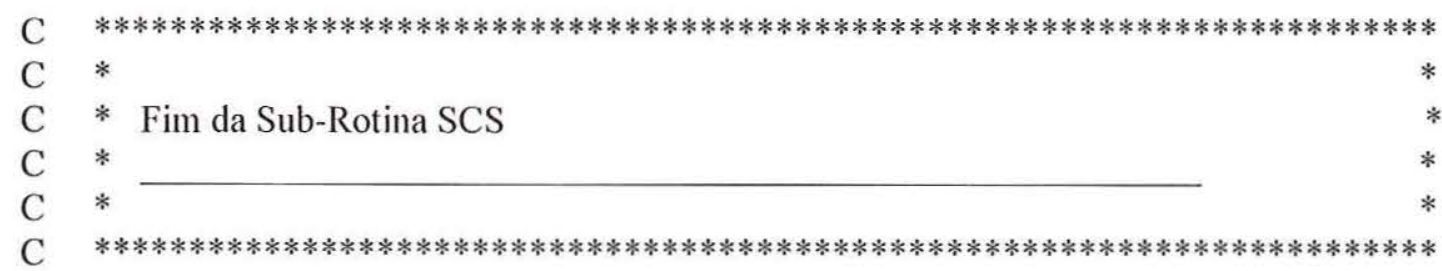




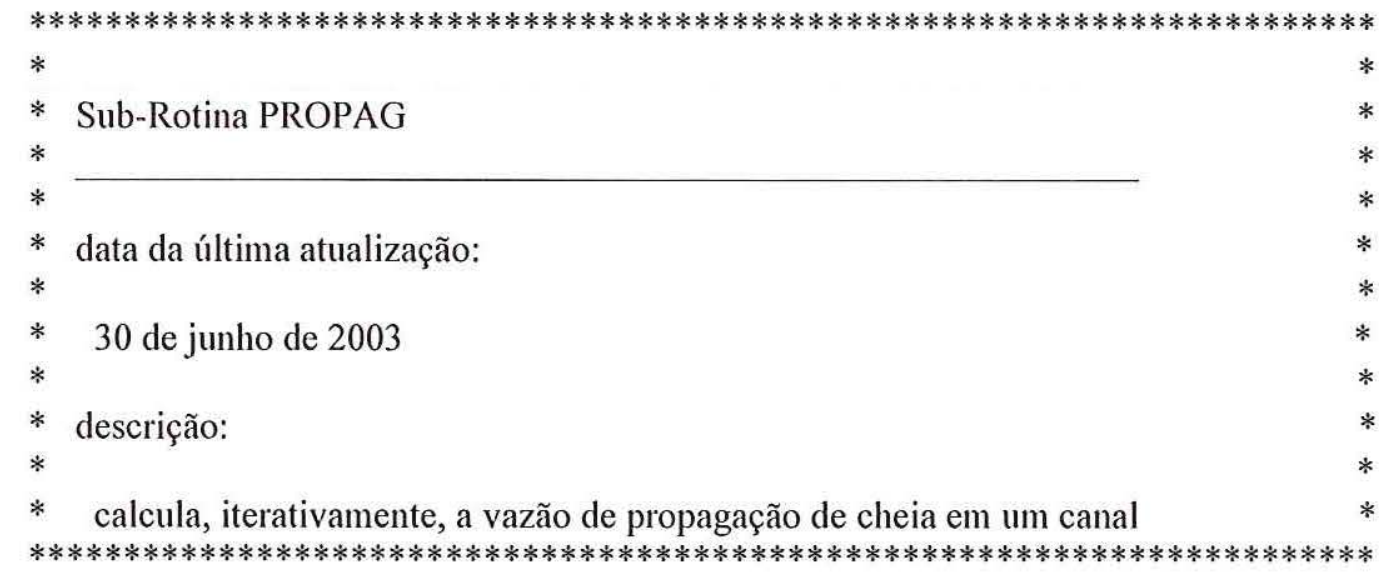

SUBROUTINE PROPAG (ALFA,BETA,DX,KT,DT,QO,QP,QBASE)

C definindo variáveis locais da sub-rotina

DIMENSION QO(500),QP(500)

C WRITE(6,666)ALFA,BETA,DX,KT,DT,QBASE

C666 FORMAT(1X,'ALFA,BETA,DX,DT,QBASE=',3F10.3,I10,2F10.3)

C WRITE(6,667)(QO(K),K=1,KT)

C667 FORMAT(1X,6F10.3)

TETA=DT/DX

DO $20 \mathrm{~K}=1, \mathrm{KT}$

$20 \quad \mathrm{QP}(\mathrm{K})=\mathrm{QBASE}$

DO $5 \mathrm{~K}=1, \mathrm{KT}-1$

C WRITE $(6,200) \mathrm{K}$

C200 FORMAT( $1 \mathrm{X}, \mathrm{K}=\mathrm{K}=\mathrm{I}, \mathrm{I10})$

C WRITE $(6,110) \mathrm{QO}(\mathrm{K}+1), \mathrm{QP}(\mathrm{K})$

C110 FORMAT $\left(1 \mathrm{X},{ }^{\prime} \mathrm{QO}(\mathrm{K}+1)={ }^{\prime}, \mathrm{F} 10.3,{ }^{\prime} \mathrm{QP}(\mathrm{K})={ }^{\prime}, \mathrm{F} 10.3\right)$

$\mathrm{RO}=(\mathrm{TETA} * \mathrm{QO}(\mathrm{K}+1)+\mathrm{ALFA} * \mathrm{BETA} * \mathrm{QP}(\mathrm{K}) *(0.5 *(\mathrm{QP}(\mathrm{K})+\mathrm{QO}(\mathrm{K}+1))) * *($

* BETA-1.) $) /($ TETA+ALFA*BETA*(0.5*(QP(K)+QO $(\mathrm{K}+1))) * *(\mathrm{BETA}-1)$.

C WRITE $(6,100)$ RO

C100 FORMAT(1X,'RO=',F10.3)

DO 10 ITER $=1,10$

D1 $=$ TETA + ALFA $*$ BETA*RO $* *(B E T A-1$.

D2 $=$ ALFA $*$ BETA $*(B E T A-1)$.$* RO * *(B E T A-2$.

$\mathrm{OMEGA}=\mathrm{TETA} * \mathrm{QO}(\mathrm{K}+1)+\mathrm{ALFA} * \mathrm{QP}(\mathrm{K}) * \mathrm{BETA}$

$\mathrm{F}=\mathrm{TETA} * \mathrm{RO}+\mathrm{ALFA} * \mathrm{RO} *$ BETA

C WRITE(6,12)RO,OMEGA,F,D1,D2

C12 FORMAT(1X,'RO,OMEGA,F,D1,D2=',5F10.3) 


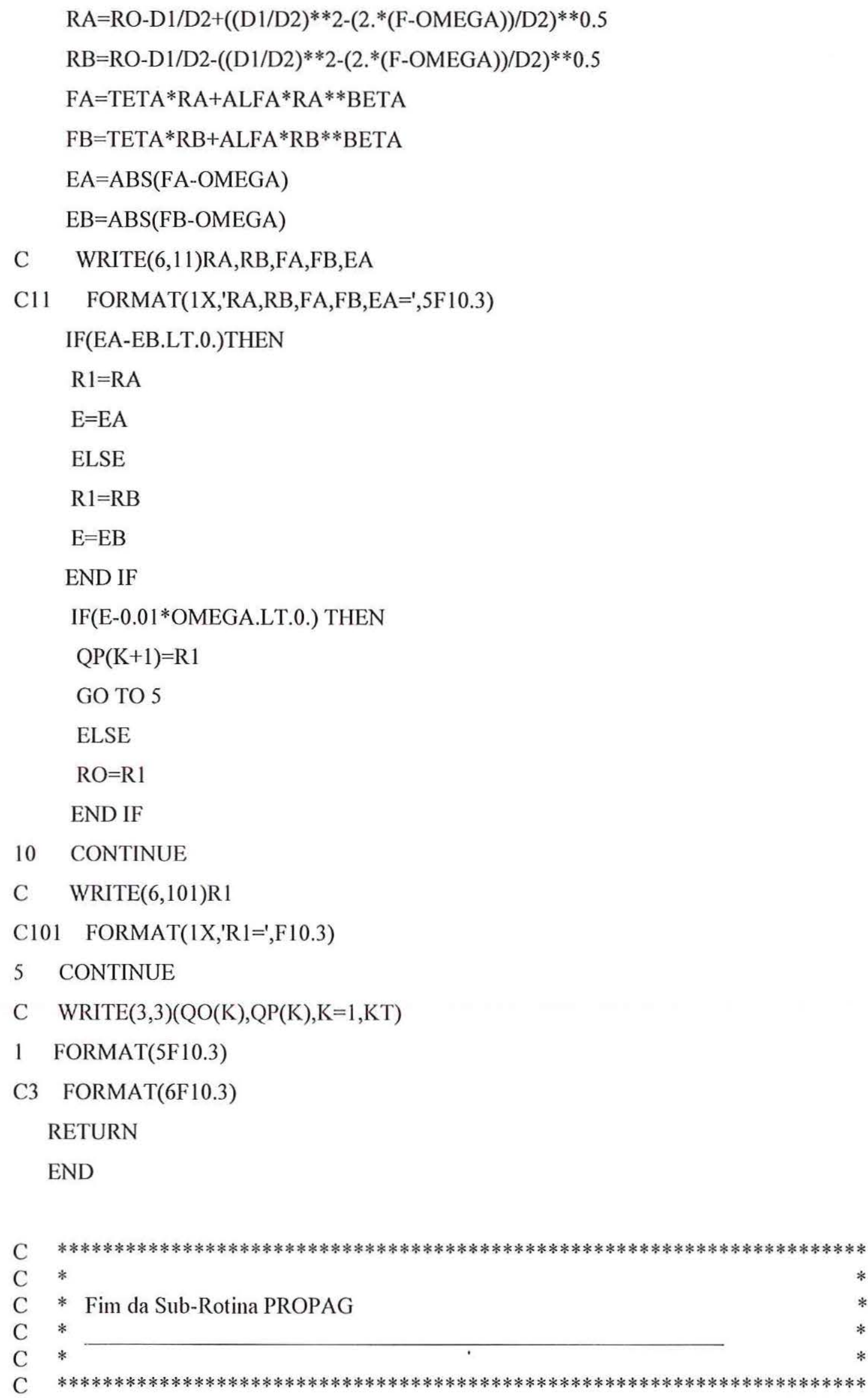




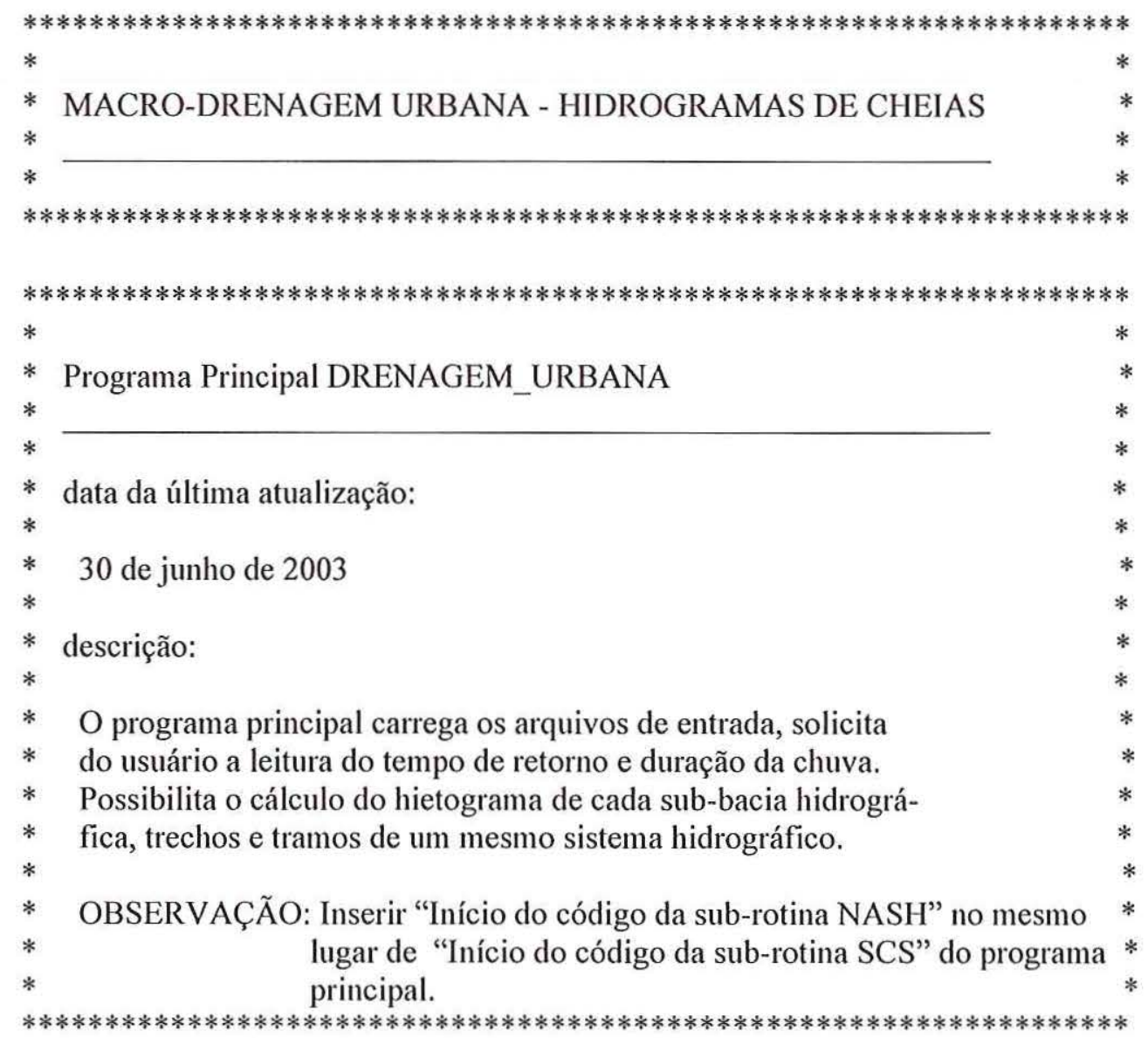

C Início do código da sub-rotina NASH

CALL NASH (ISUB,N,L,S,A,D)

IF (ITSAI.EQ.1) THEN

IF (ISUB.EQ.NSBBS) THEN

$\mathrm{ITR}=\mathrm{TR}$

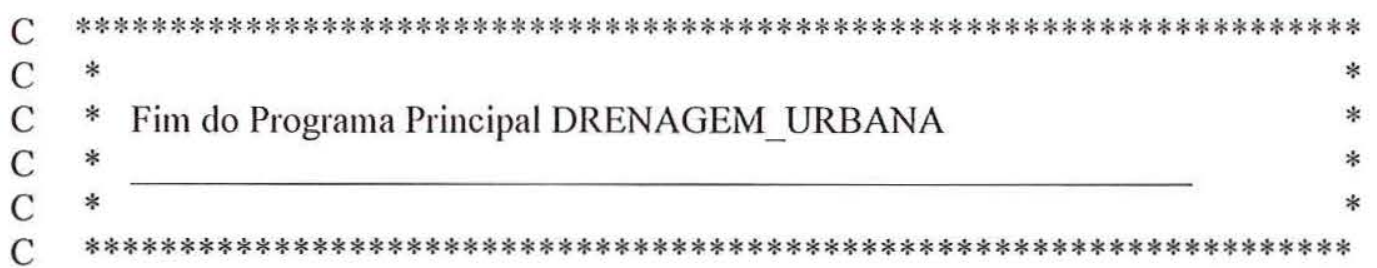




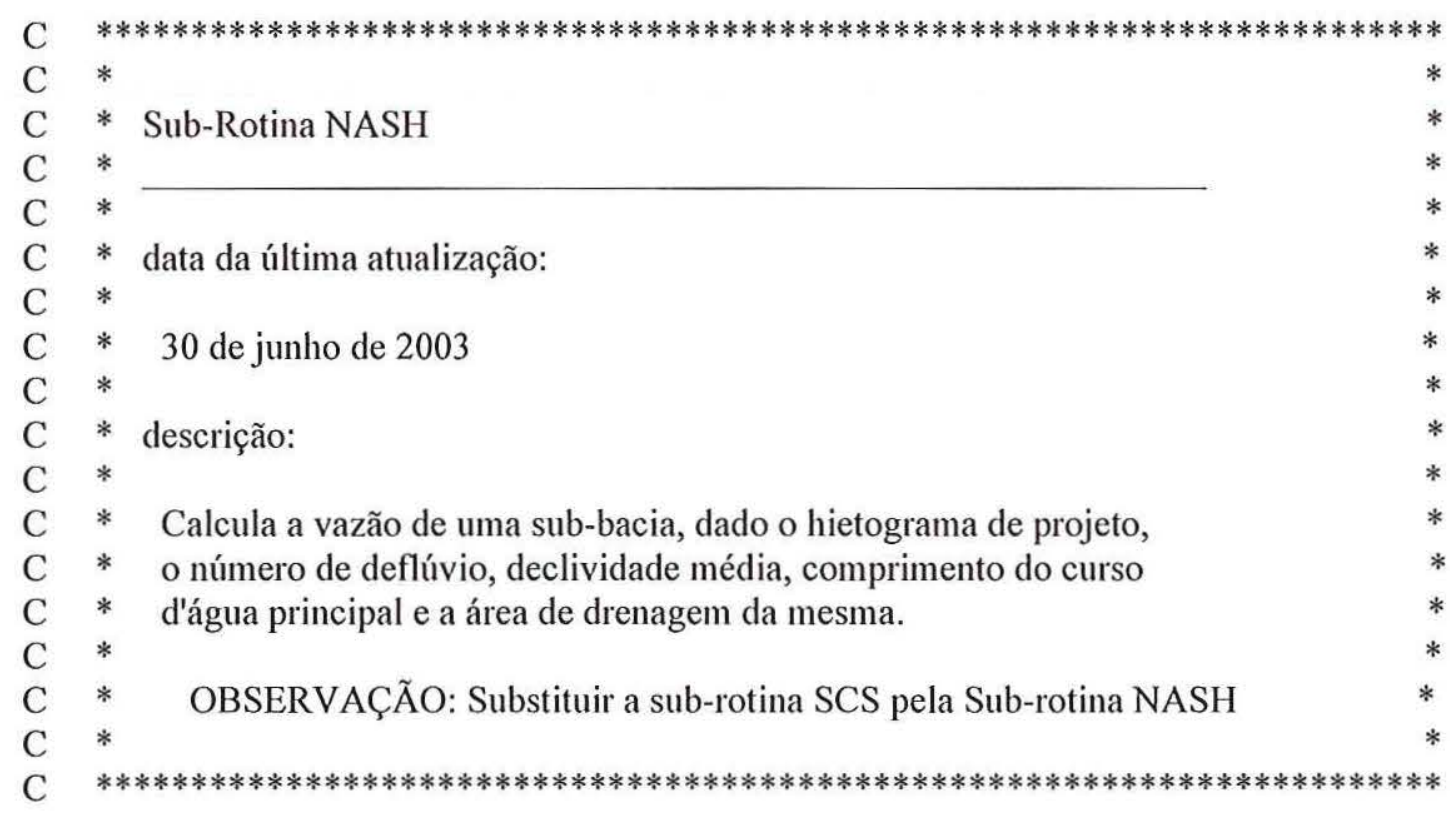

\section{SUBROUTINE NASH (NSAX,N,L,S,A,D)}

C definindo variáveis da sub-rotina

REAL N,L,KK,K1,IT,II,M

COMMON REARJ(100),QS(0:100,0:100),KTC

DIMENSION P(0:100),RE(0:100),T(0:500), SOMA(0:100),IT(0:100)

*,QU(0:100), KK(0:100),Q(0:100),O(0:100), RRE(0:100),TT(0:100)

*,FTN(0:50),II(0:50),M(0:50)

$\mathrm{KK}(0)=0$.

$\mathrm{QS}(\mathrm{NSAX}, 0)=0$.

C...........CÁlCULO DA CHUVA EFETIVA PELO MÉTODO NASH

$\mathrm{P}(0)=0$.

DO $4 \mathrm{~J}=0, \mathrm{KTC}$

$\mathrm{P}(\mathrm{J}+1)=\operatorname{REARJ}(\mathrm{J}+1)+\mathrm{P}(\mathrm{J})$

$\operatorname{RE}(\mathrm{J})=(\mathrm{P}(\mathrm{J})-5080 / \mathrm{N}+50.8) * 2 /(\mathrm{P}(\mathrm{J})+20320 / \mathrm{N}-203.2)$

IF(P(J).LT.5080/N-50.8) THEN

$$
\operatorname{RE}(\mathrm{J})=0 .
$$

ELSE

END IF

4 CONTINUE 


\section{C ...INÍCIO DO CÁLCULO DO HIDROGRAMA A PARTIR DA CHUVA EFETIVA...}

$\mathrm{SS}=\mathrm{S} *(10 * 4)$

C ALPHA - Alfa

ALPHA $=\mathrm{L} * 0.1 / 0.43$

$\mathrm{K} 1=8.921 * \mathrm{~A} * 0.3 /(\mathrm{SS} * * 0.3 * \mathrm{~L} * 0.1)$

$\mathrm{W}=\mathrm{ALPHA}-1$

C FGAMA - Função gama

FGAMA $=((\mathrm{W} * * \mathrm{~W} * \mathrm{SQRT}(6.2832 * \mathrm{~W})) / \mathrm{EXP}(\mathrm{W})) *(1+0.0833 / \mathrm{W}+0.0035 /$

$* \mathrm{~W} * 2-139 /(51840 * \mathrm{~W} * * 3))$

C WRITE(*,*)K1,A,L,S

$\mathrm{J}=0$

$\mathrm{FTN}(\mathrm{J})=1$

$\operatorname{IT}(\mathrm{J})=0$

$\mathrm{TT}(\mathrm{J})=0$

DO $14 \mathrm{~J}=1,50$

$\mathrm{CONTJ}=\mathrm{J}$

$\mathrm{T}(\mathrm{J})=\mathrm{J}$

$\mathrm{TT}(\mathrm{J})=\mathrm{T}(\mathrm{J}) / \mathrm{K} 1$

C $\quad \mathrm{N}=0$

C WRITE $(*, *)$ "PASSOU"

$\operatorname{SOMA}(0)=(\mathrm{TT}(\mathrm{J}) * *$ ALPHA $) /$ ALPHA

DO $75 \mathrm{NN}=1,30$

$\mathrm{FTN}(\mathrm{NN})=\mathrm{NN} * \mathrm{FTN}(\mathrm{NN}-1)$

$\mathrm{CONT}=\mathrm{NN}$

SOMA(NN) $=$ SOMA(NN-1)+((-1)**NN*TT(J)**(ALPHA+NN))/(FTN(NN)

* * $\quad$ (ALPHA $+\mathrm{NN}))$

IF (ABS(SOMA(NN)-SOMA(NN-1)).LE.0.0001) THEN

GO TO 10

END IF

75 CONTINUE

$10 \quad \mathrm{IT}(\mathrm{J})=\mathrm{SOMA}(\mathrm{CONT}) / \mathrm{FGAMA}$

IF ((1-IT(J)).LE.0.005) THEN

GO TO 20

END IF

14 CONTINUE

C $\quad \mathrm{J}=0$ 


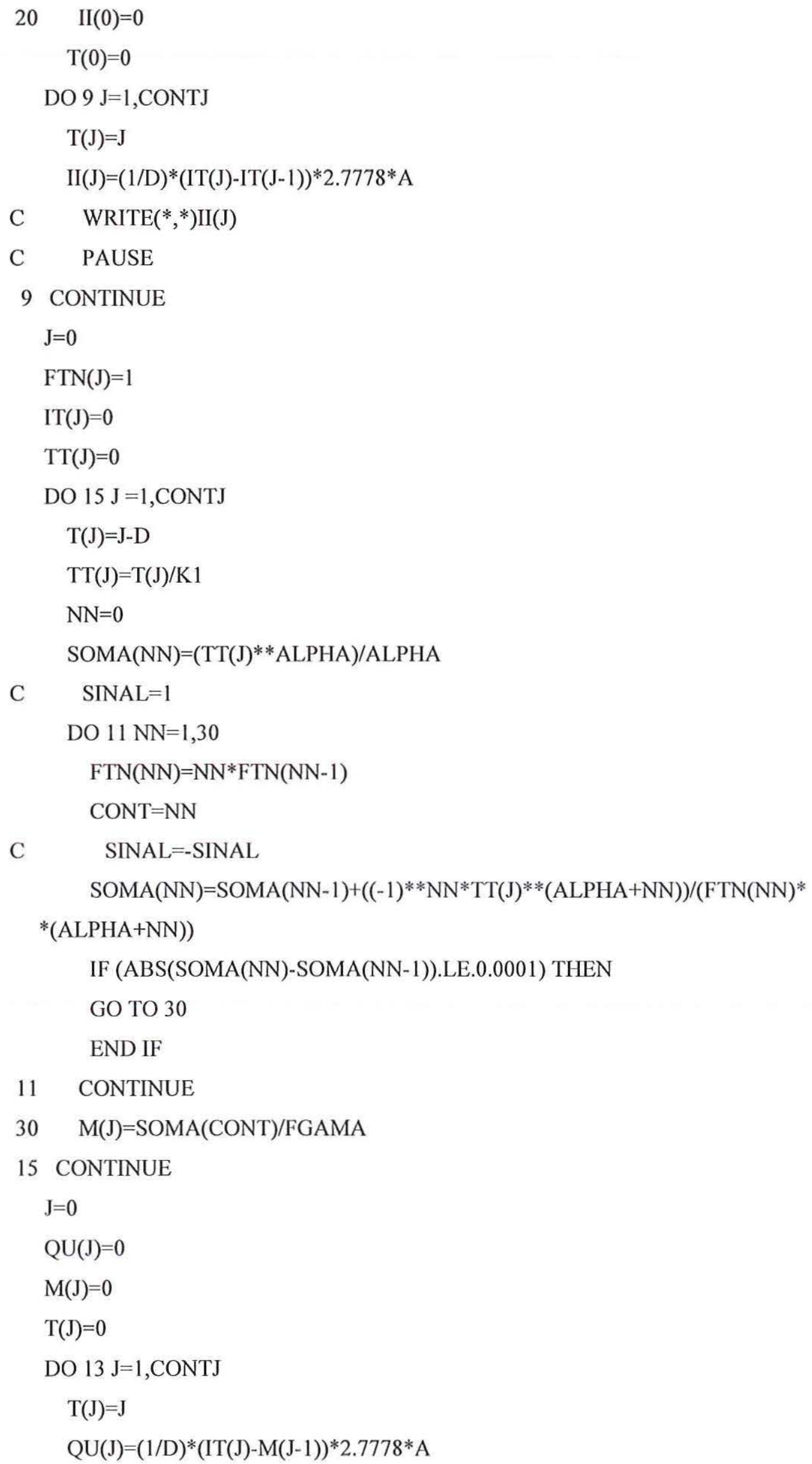


13 CONTINUE

DO $500 \mathrm{~J}=(\mathrm{CONTJ}+1), 2 * \mathrm{KTC}$

$\mathrm{QU}(\mathrm{J})=0$

500 CONTINUE

DO $5 \mathrm{~J}=0, \mathrm{KTC}$

$\mathrm{RRE}(\mathrm{J}+1)=\mathrm{RE}(\mathrm{J}+1)-\mathrm{RE}(\mathrm{J})$

$\mathrm{Q}(\mathrm{J})=\operatorname{RRE}(\mathrm{J}) / 10$.

5 CONTINUE

C.........CONVOLUÇÃO DO HIDROGRAMA.......................

C convolução entre "hidrograma unitário triangular" e

C "escoamento superficial direto"

$\mathrm{OO}=0$.

$\mathrm{IBB}=1$

DO $6 \mathrm{JJ}=1,2 * \mathrm{KTC}$

$\mathrm{T}(\mathrm{JJ})=\mathrm{FLOAT}(\mathrm{JJ}) * \mathrm{D}$

DO $7 \mathrm{~J}=1, \mathrm{JJ}$

$\mathrm{KL}=\mathrm{JJ}-\mathrm{J}+1$

IF(KL.LT.0) THEN

$\mathrm{KL}=0$

ELSE

END IF

$\mathrm{O}(\mathrm{JJ})=\mathrm{Q}(\mathrm{J}) * \mathrm{QU}(\mathrm{KL})$

$\mathrm{OO}=\mathrm{OO}+\mathrm{O}(\mathrm{JJ})$

7 CONTINUE

C WRITE(6,666)JJ,O(JJ)

C666 FORMAT(1X,'JJ,O(JJ)=',I10,F10.3)

$\mathrm{KK}(\mathrm{IBB})=\mathrm{OO}$

$\mathrm{IBB}=\mathrm{IBB}+1$

$\mathrm{OO}=0$.

6 CONTINUE

DO $200 \mathrm{~J}=1,2 * \mathrm{KTC}$

$200 \mathrm{QS}(\mathrm{NSAX}, \mathrm{J})=\mathrm{KK}(\mathrm{J})$

C WRITE(3,111)NSAX

C WRITE(3,100)TC,TP

C WRITE(3,760)NSAX,N,L,PP,S,A 
C WRITE $(3,100)(\mathrm{T}(\mathrm{J}), \mathrm{KK}(\mathrm{J}), \mathrm{J}=0,2 * \mathrm{KTC})$

100 FORMAT(6F10.3)

111 FORMAT(I10)

760 FORMAT(I10,5F 10.3)

RETURN

END

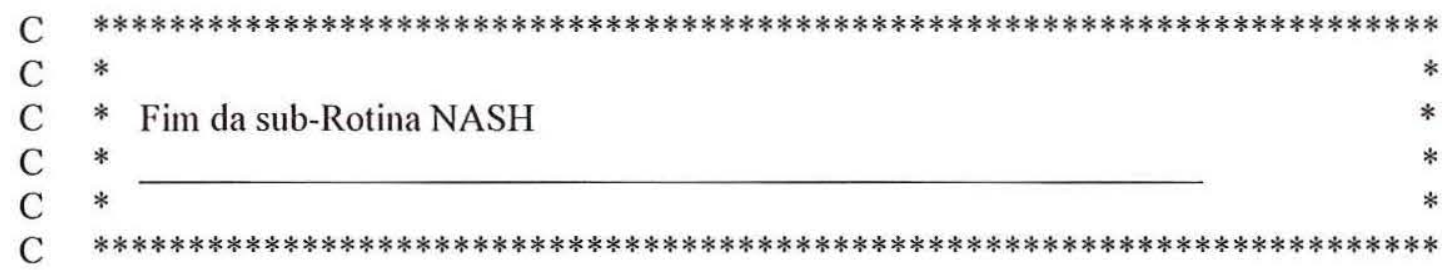



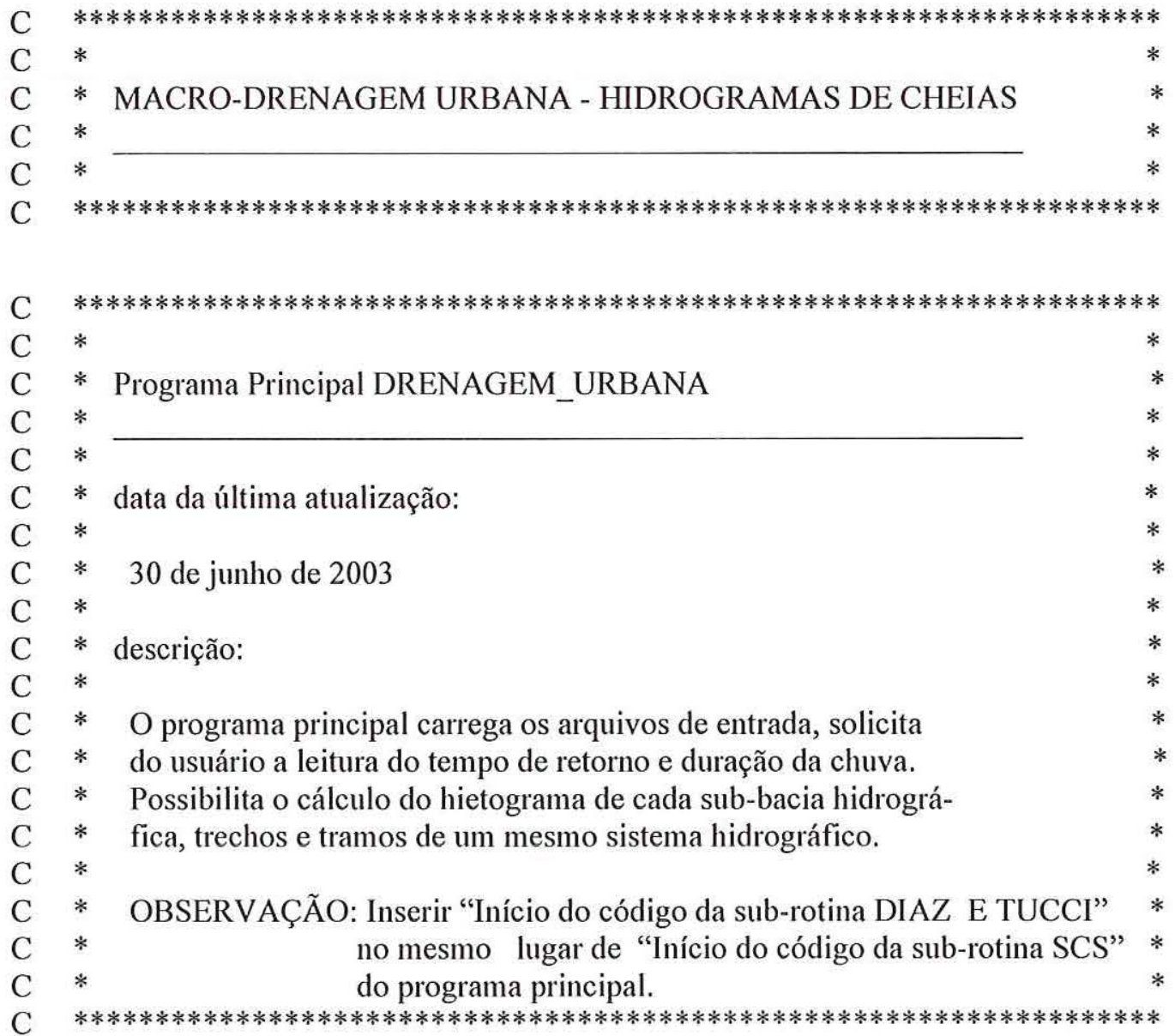

C Início do código da sub-rotina DIAZ E TUCCI

CALL DIAZ E TUCCI (ISUB,N,L,S,A,D)

IF(ITSAI.EQ.1) THEN

IF(ISUB.EQ.NSBBS) THEN

$\mathrm{ITR}=\mathrm{TR}$

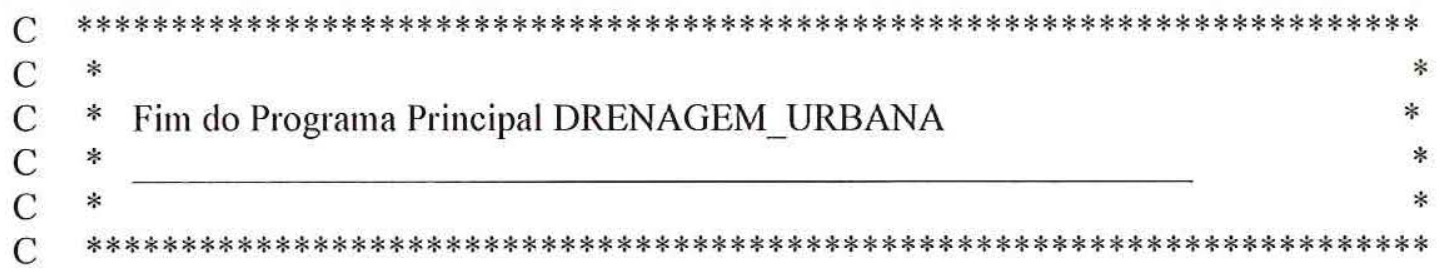




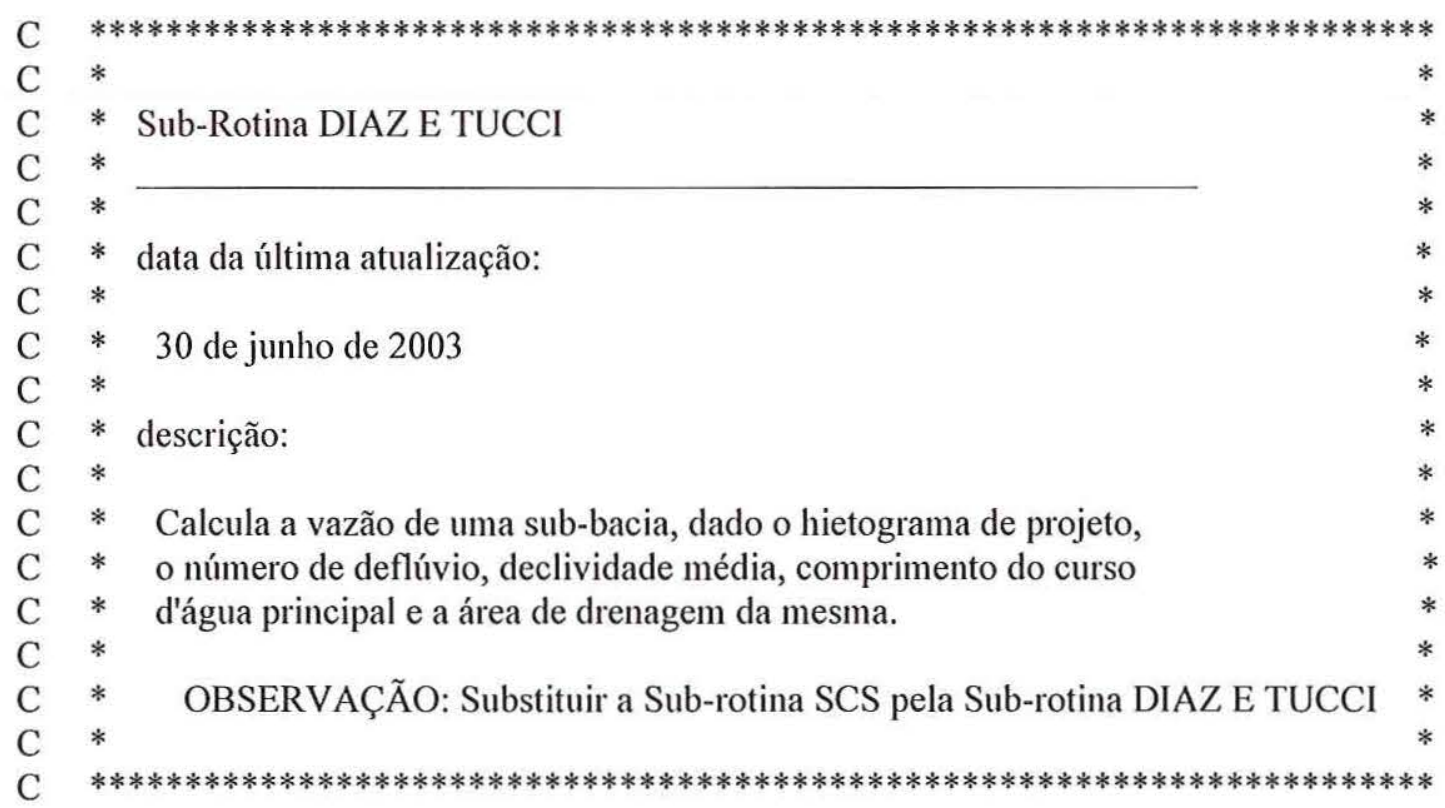

\section{SUBROUTINE DIAZ E TUCCI (NSAX,N,L,S,A,D)}

REAL N,L,KK,L25,L50

COMMON REARJ(100),QS(0:100,0:100),KTC

DIMENSION P(0:100),RE(0:100),T(500)

*,QU(0:100), KK(0:100),Q(0:100),O(0:100), RRE(0:100)

$\mathrm{KK}(0)=0$.

$\mathrm{QS}(\mathrm{NSAX}, 0)=0$.

C...........CÁlCULO DA CHUVA EFETIVA PELO MÉTODO DIAZ E TUCCI

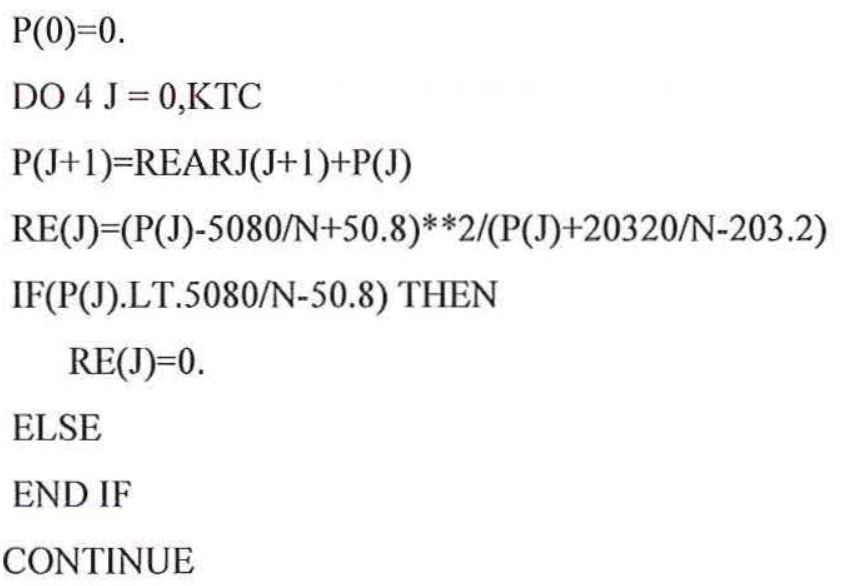




\section{C ...INÍCIO DO CÁLCULO DO HIDROGRAMA A PARTIR DA CHUVA EFETIVA...}

$\mathrm{SS}=\mathrm{S} * 100$

$\mathrm{IP}=2.25 *(\mathrm{~N}-60)$

C QP - Vazão de pico

$\mathrm{QP}=0.07 * \mathrm{~A} * * .44 * \mathrm{~L} * * .78 * \mathrm{SS} * * .19 * \mathrm{IP} * .39$

C TP-Tempo de pico

$\mathrm{TP}=(7.82 * \mathrm{QP} * *(-1) * \mathrm{~A} * * 1.22) / 60$

C Largura a $25 \%$ da vazão de pico

$\mathrm{L} 25=\left(25.6 * \mathrm{QP} * *(-.84) * \mathrm{~A} * * .89 * \mathrm{SS}^{* *}(-0.08)\right) / 60$

C Largura a $50 \%$ da vazão de pico

$\mathrm{L} 50=(14.8 * \mathrm{QP} * *(-.84) * \mathrm{~A} * * .89) / 60$

C TB - Tempo de base

$\mathrm{TB}=(2 *(10 * 3 * \mathrm{~A} /(.25 * \mathrm{QP})-3600 * \mathrm{~L} 25-1.5 * 3600 * \mathrm{~L} 50)) / 3600$

DO $14 \mathrm{~J}=0$,KTC

$\mathrm{T}(\mathrm{J})=\operatorname{FLOAT}(\mathrm{J}) * \mathrm{D}$

IF (T(J).LE.TP) THEN

$\mathrm{QU}(\mathrm{J})=\mathrm{T}(\mathrm{J}) *(\mathrm{QP} / \mathrm{TP})$

ELSE

IF (T(J).GT.TP .AND. T(J).LE..5*TP+L50) THEN

$\mathrm{QU}(\mathrm{J})=.5 * \mathrm{QP}+((\mathrm{L} 50+.5 * \mathrm{TP}-\mathrm{T}(\mathrm{J})) * .5 * \mathrm{QP}) /(\mathrm{L} 50-.5 * \mathrm{TP})$

ELSE

IF (T(J).GT..5*TP+L50.AND.T(J).LE..25*TP+L25) THEN

$\mathrm{QU}(\mathrm{J})=.25 * \mathrm{QP}+((\mathrm{L} 25+.25 * \mathrm{TP}-\mathrm{T}(\mathrm{J})) * .25 * \mathrm{QP}) /$

* (L25-L50-.25*TP)

ELSE

IF (T(J).GT..25*TP+L25 .AND. T(J).LT.TB) THEN

$\mathrm{QU}(\mathrm{J})=((\mathrm{TB}-\mathrm{T}(\mathrm{J})) * 25 * \mathrm{QP}) /(\mathrm{TB}-.25 * \mathrm{TP}-\mathrm{L} 25)$

ELSE

IF (T(J).GE.TB) THEN

$\mathrm{QU}(\mathrm{J})=0$

END IF

END IF

END IF

END IF

END IF

14 CONTINUE 
DO $5 \mathrm{~J}=0, \mathrm{KTC}$

$\operatorname{RRE}(\mathrm{J}+1)=\mathrm{RE}(\mathrm{J}+1)-\mathrm{RE}(\mathrm{J})$

$\mathrm{Q}(\mathrm{J})=\operatorname{RRE}(\mathrm{J}) / 1$

5 CONTINUE

C.........CONVOLUÇÃO DO HIDROGRAMA......................

C convolução entre "hidrograma unitário triangular" e

C "escoamento superficial direto"

$\mathrm{OO}=0$.

$\mathrm{IBB}=1$

DO $6 \mathrm{JJ}=1,2 * \mathrm{KTC}$

$\mathrm{T}(\mathrm{JJ})=\mathrm{FLOAT}(\mathrm{JJ}) * \mathrm{D}$

DO $7 \mathrm{~J}=1, \mathrm{JJ}$

$\mathrm{KL}=\mathrm{JJ}-\mathrm{J}+1$

IF(KL.LT.0) THEN

$\mathrm{KL}=0$

ELSE

END IF

$\mathrm{O}(\mathrm{JJ})=\mathrm{Q}(\mathrm{J}) * \mathrm{QU}(\mathrm{KL})$

$\mathrm{OO}=\mathrm{OO}+\mathrm{O}(\mathrm{JJ})$

7 CONTINUE

C WRITE(6,666)JJ,O(JJ)

C666 FORMAT(1X,'JJ,O(JJ)=',I10,F10.3)

$\mathrm{KK}(\mathrm{IBB})=\mathrm{OO}$

$\mathrm{IBB}=\mathrm{IBB}+1$

$\mathrm{OO}=0$.

6 CONTINUE

DO $200 \mathrm{~J}=1,2 * \mathrm{KTC}$

200 QS(NSAX,J)=KK(J)

C WRITE $(3,111)$ NSAX

C WRITE $(3,100)$ TC,TP

C WRITE( 3,760$)$ NSAX,N,L,PP,S,A

C $\operatorname{WRITE}(3,100)(\mathrm{T}(\mathrm{J}), \mathrm{KK}(\mathrm{J}), \mathrm{J}=0,2 * \mathrm{KTC})$

100 FORMAT(6F 10.3)

111 FORMAT(I10)

760 FORMAT(I10,5F10.3) 
RETURN

END

C $\quad * * * * * * * * * * * * * * * * * * * * * * * * * * * * * * * * * * * * * * * * * * * * * * * * * * * * * * * * * * * * * * * * * * * * * * *$

C *

$\mathrm{C} *$ Fim da sub-Rotina DIAZ E TUCCI

$\mathrm{C} *$

C $\quad * * * * * * * * * * * * * * * * * * * * * * * * * * * * * * * * * * * * * * * * * * * * * * * * * * * * * * * * * * * * * * * * * * * * * * *$ 
ANEXO F - Arquivos de entrada 


\section{ARQUIVO DE DADOS CHUVADA}

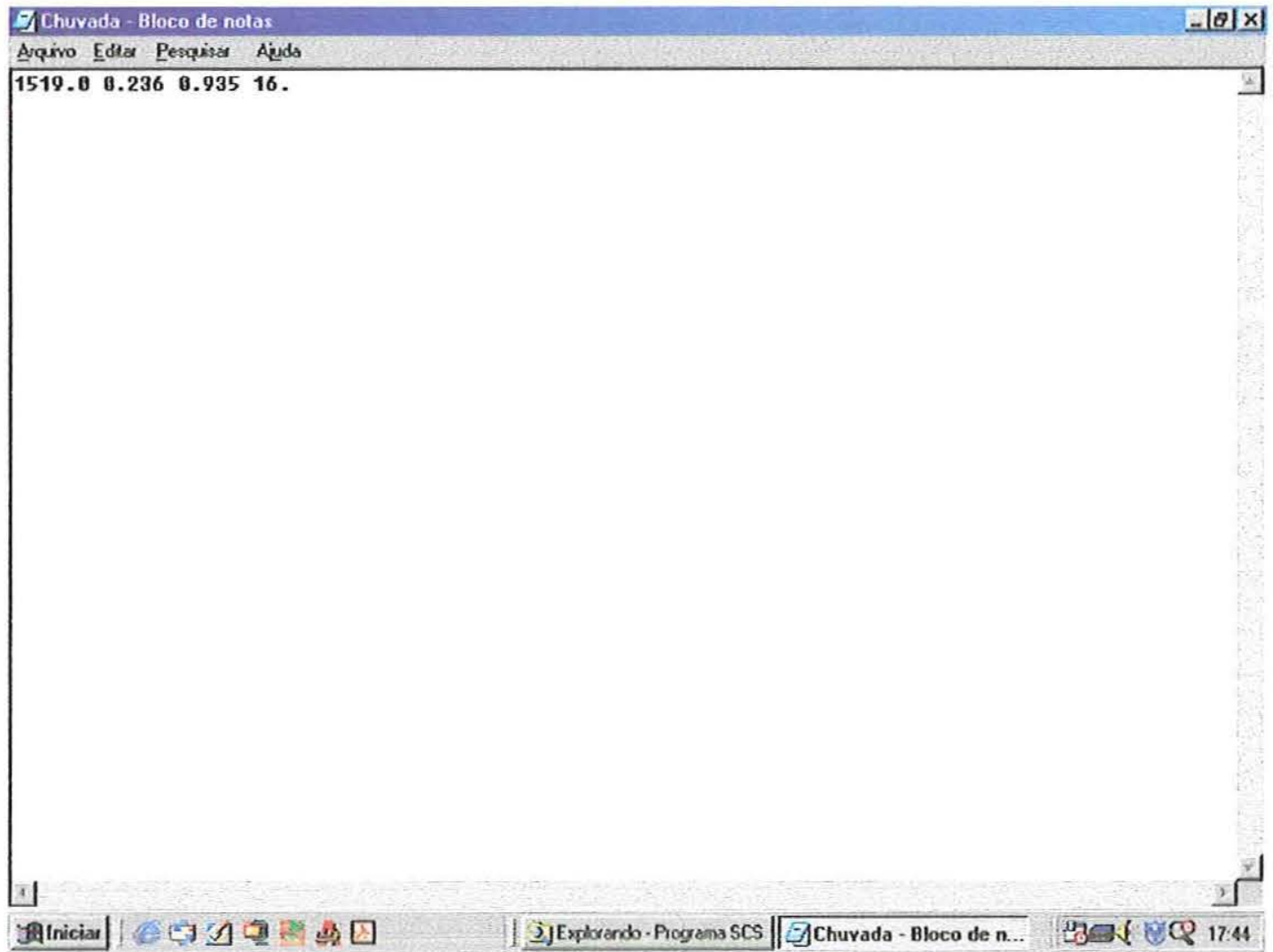

ARQUIVO DE DADOS DREDADB

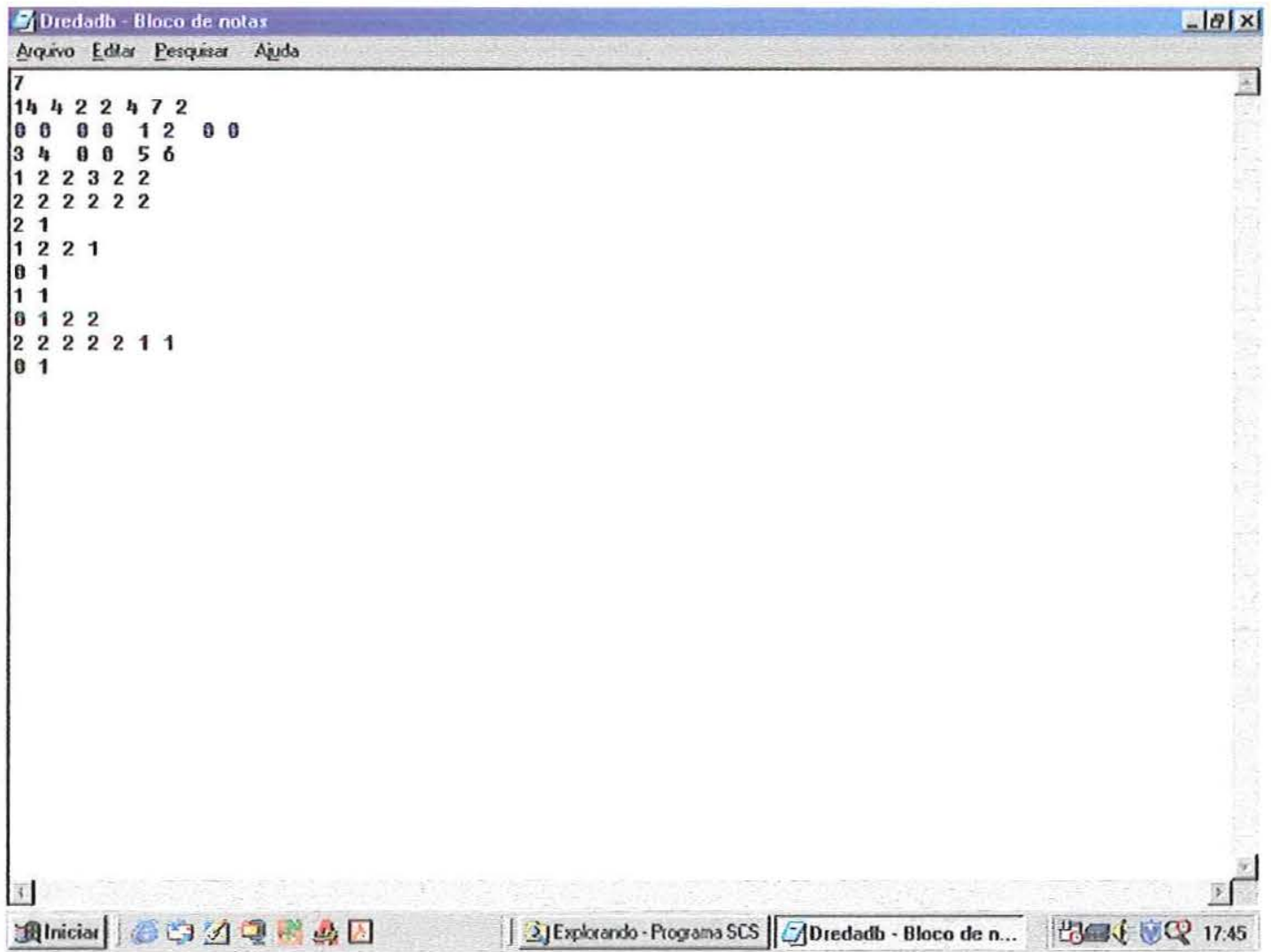




\section{ARQUIVO DE DADOS SUBDADB}

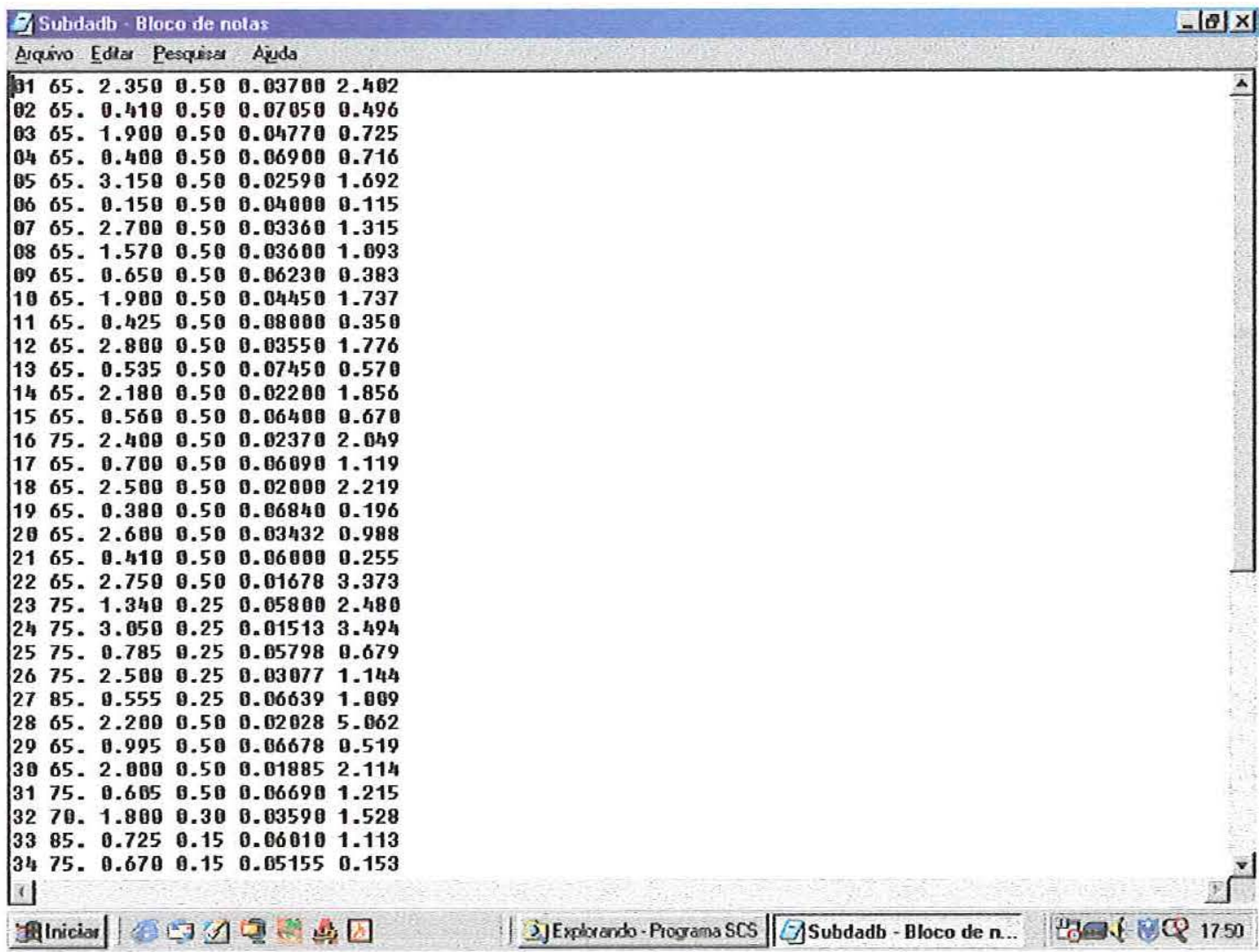

\section{ARQUIVO DE DADOS SUBDADB (CONTINUAÇÃO)}

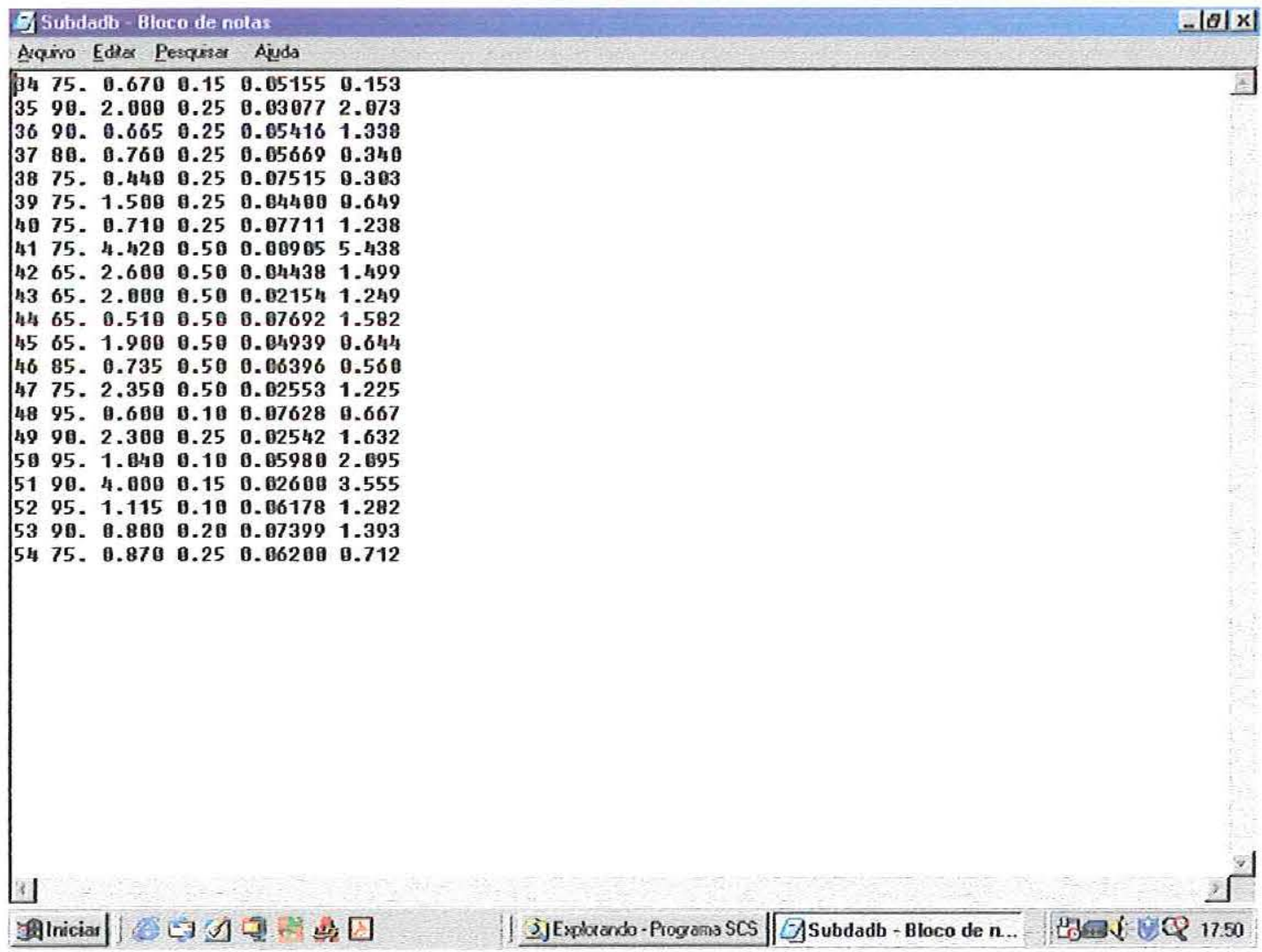




\section{ARQUIVO DE DADOS TREDADB}

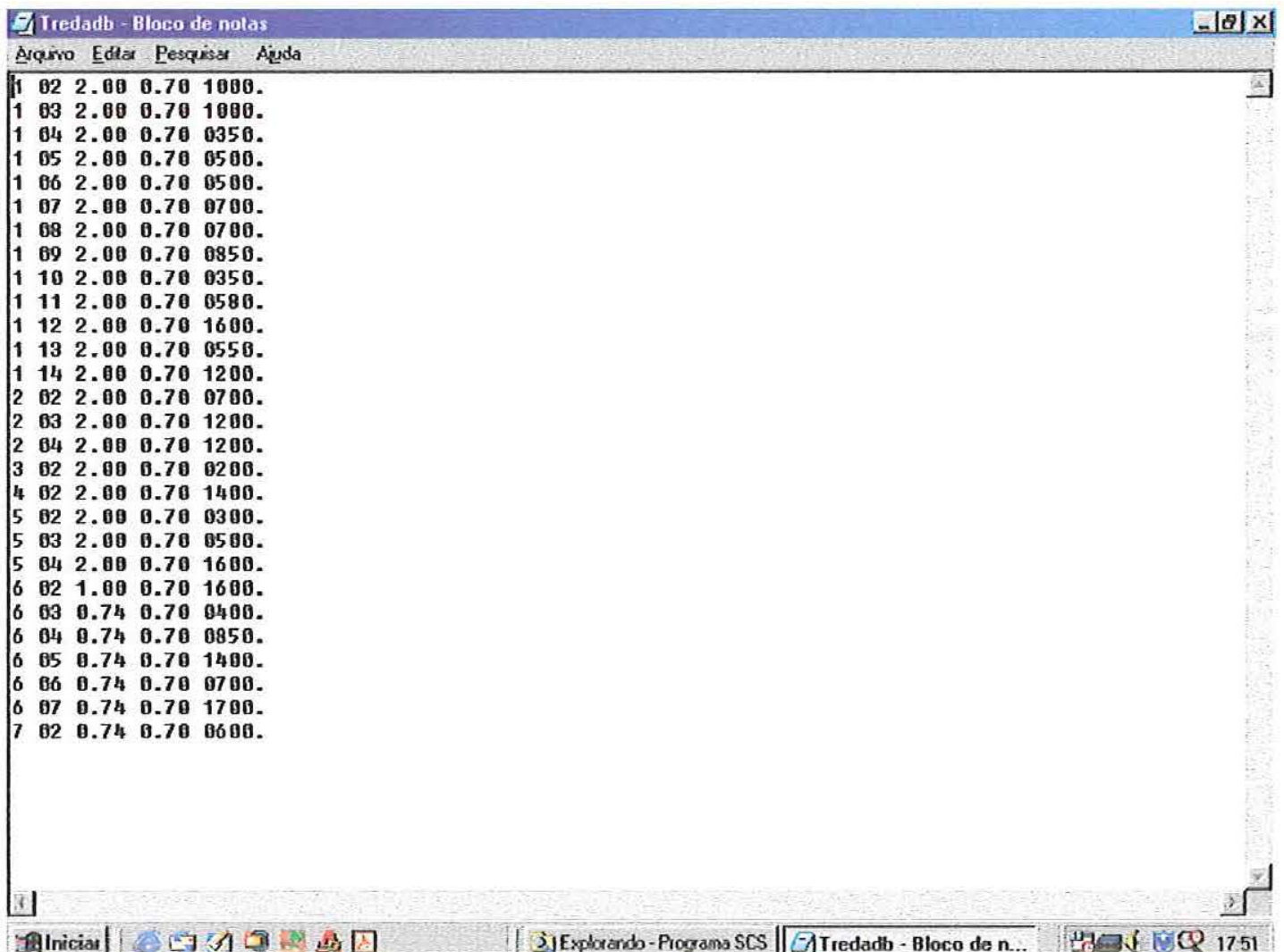

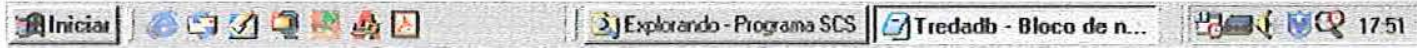


ANEXO G - Programa do modelo EESC - Disquete 
"DISQUETE DISPONÍVEL PARA EMPRËSTTMO NO BALCÃO DE ATENDTMENTO." 
ANEXO H - Perfil da seção utilizada neste estudo e retirada do relatório elaborado pelo escritório de consultoria e projetos de engenharia Itda - Shs 


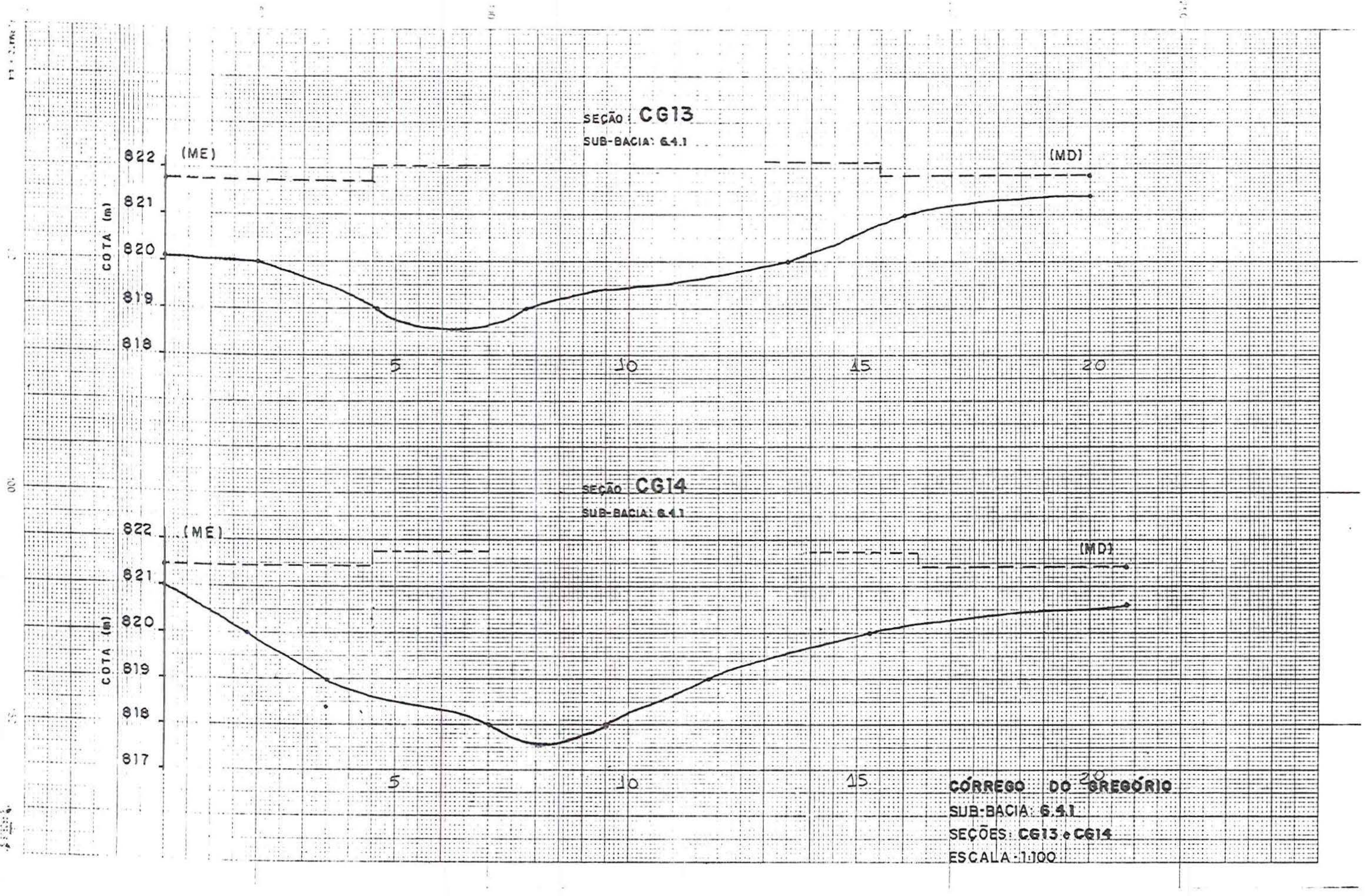




\section{REFERÊNCIAS BIBLIOGRÁFICAS}

BARBASSA, A.P. (1991). Simulação do Efeito da Urbanização sobre a Drenagem Pluvial na Cidade de São Carlos/SP. p.327. Tese (Doutorado) - Escola de Engenharia de São Carlos - Universidade de São Paulo (USP), Departamento de Hidráulica e Saneamento. São Carlos, 1991.

BISINOTO, D.A. (1988). Evolução Urbana de São Carlos. São Carlos. Dissertação (Mestrado) - Escola de Engenharia de São Carlos - USP, Departamento de Arquitetura.

BUTLER, D.; PARKINSON, J. (1997). Towards Sustainable Urban Drainage. Water Science Technology. Vol.35, № 09, p.53-63, Ed. Elsevier Science Ltd.

CHOW, V.T. (1959). Open Channel Hydraulics. McGraw Hill, p.680.

CONFERÊNCIA DA CIDADE (2002). Prefeitura Municipal de São Carlos-SP. São Carlos, 24 de Agosto de 2002. 1CD.

COSTA JUNIOR, L.L. (2003). Avaliação da Ocupação e Impermeabilização do Solo e do Emprego de Medidas de Controle de Inundação no Lote Bacia Hidrográfica Ponte Seca - Jaboticabal/SP. p.150. Dissertação (Mestrado) - Universidade Federal de São Carlos (UFSCAR), Curso de Pós-Graduação em Engenharia Urbana. São Carlos, 2003.

DEVESCOVI, R.C.B. (1987). Urbanização e Acumulação: Um Estudo Sobre a Cidade de São Carlos. São Carlos: Arquivo de História Contemporânea - UFSCar, 1987, p.261.

DIAZ, O.B.P.; TUCCI, C.E. (1989). Regionalização de Hidrogramas Unitários de Bacias Brasileiras. R.B.E. Vol. 7, p.19-29.

FERREIRA, A.B.H. (1986). Novo Dicionáio da Língua Portuguesa. Nova fronteira. $2^{\mathrm{a}}$ ed., Rio de Janeiro.

FIGUEIREDO, G.A.B.G. (2000). Sistemas Urbanos de Água: Avaliação de Método para Análise de Sustentabilidade Ambiental de Projetos.Dissertação (Mestrado) Universidade Federal de São Carlos (UFSCAR), Curso de Pós-Graduação em Engenharia Urbana, São Carlos. 2000.

GRADSHTEIN, J.S. e RYZHIK, J.M. (1965). Table of Integral Séries and Products. Academic Press, New York, $4^{\mathrm{a}}$ Ed., p.1086. 
HALL, M.J. (1984). Urban Hydrology. Elsevier Applied Publishers, London and Swindon, UK, p.299.

LI, R.M.; SIMONS, D.B.; STEVENS, M.A. (1975). Nonlinear Kinematic Wave Approxomation. Water Resources Research, Vol. 11, № 2: p.245-252.

LINDLEY, R.W. (1976). A Case Study: Green Trail Development, Lisle Illinois. Proceedings National Symposium on Urban Hydrology, Hydraulics, and Sediment Control. Univ of Kentucky.

LINSLEY, R.K.; FRANZINI, J.B. (1978). Engenharia de Recursos Hídricos. São Paulo: Mcgraw-Hill do Brasil, p.798.

MACHADO, E.S. (1981). Modelo Hidrológico Determinístico para Bacias Urbanas. p.286. Tese (Doutorado) - Escola de Engenharia de São Carlos - Universidade de São Paulo (USP), Departamento de Hidráulica e Saneamento. São Carlos, 1981.

MAIA, A.G. (2002). Simulação em Tempo Real como Ferramenta de Decisão no Gerenciamento de Estoques de Água de Reservatórios. p.143. Dissertação (Mestrado) - Escola de Engenharia de São Carlos - Universidade de São Paulo. São Carlos, 2002.

NASH, J.E. (1959). The Form of the Instantaneos Unit Hydrograph. IAHS, Assemblee Generale de Toronto, Tome III, p.114-121.

NASH, J.E. (1960). A Unit Hydrograph Study, with Particular Reference to British Catchments. Proceedinngs of Institution of Civil Engineers. Vol. 17, p.249-282.

PEREZ JUNIOR, O.R. (2003). Características Físicas da Cidade de São Carlos. Disponível em http://educar.sc.usp.br/biologia/textos/m_a_txt6.html. Acesso em PORTO, R.M.; RIGHETTO, A.M. (1995). Análise Comparativa de Métodos Hidrológicos Simples em Drenagem Urbana. XI Simpósio Brasileiro de Recursos Hídricos. Recife, 7 a 12 de Novembro de 1995. Vol. 3, p.505-514.

RELATÓRIO PÓLIS (2002). Assessoria Técnica para Elaboração do Plano Diretor de São Carlos. Leitura técnica da cidade (Produto 1), São Paulo, Outubro de 2002.

RIBEIRO, G. (1961). Acerca do Cálculo da Vazão de Obras D'Arte. Revista do Clube de Engenharia. № 249 , Rio de Janeiro, p.16-19.

RIGHETTO, A.M. (1998). Hidrologia e Recursos Hídricos. Departamento de Hidráulica e Saneamento - Escola de Engenharia de São Carlos, Universidade de São Paulo. Publicação EESC/USP, São Carlos-SP, p.819. 
RIGHETTO, A.M.; PORTO, R.M. (1994). Seminário sobre Hidráulica Computacional Aplicada a Problemas de Drenagem Urbana. ABRH, 16 de Agosto de 1994, São Paulo, p.30.

SADOUN, B. (2000). Applied System Simulation: a review study. Informayion Science. Elsevier Science Inc. Vol. 124. p.173-192.

SHS-CONSULTORIA E PROJETOS DE ENGENHARIA LTDA (1993). Plano Diretor de Macrodrenagem da Cidade de São Carlos. Relatório de Andamento, № 3, Modelo Hidrológico, Julho de 1993, p.77.

SILVA, K.A. (2003). Análise da Variabilidade Espacial da Precipitação e Parâmetros Hidrológicos em uma Bacia Experimental: Estudo Teórico-Experimental da Transformação da Chuva em uma Pequena Bacia Hidrográfica Urbana. São Carlos. Dissertação (Doutorado) - Escola de Engenharia de São Carlos, Departamento de Hidráulica e Saneamento, Universidade de São Paulo, Volume I - p.163 e Volume II - p.256.

TUCCI, C.E.M. (2001). Hidrologia Ciência e Aplicação. Associação Brasileira de Recursos Hídricos (ABRH). Porto Alegre: Ed. Universidade/UFRGS, $2^{\mathrm{a}}$ ed., p.943.

TUCCI, C.E.M. et al (1995). Drenagem Urbana. ABRH. Editora da Universidade. UFRGS. Porto Alegre/RS.

TUCCI, C.E.M. (1998). Modelos Hidrológicos. Associação Brasileira de Recursos Hídricos (ABRH), Ed. Universidade/UFRGS, Porto Alegre/RS, p.669.

TUCCI, C.E.M.; MARQUES, D.M.L.M. (2001). Avaliação e Controle da Drenagem Urbana. Porto Alegre: Ed. ABRH, Vol. 2, $1^{\text {a }}$ ed., p.548.

VAZ FILHO, P. (2000). Sistema de Micro-Drenagem Urbana: Análise de Aspectos de Funcionamento para Elaboração de Plano Gerencial. p.181. Dissertação (Mestrado) - Universidade Federal de São Carlos (UFSCAR). São Carlos, 2000.

VICENTINI, T.A. (2000). Análise do Efeito da Urbanização nas Cheias Urbanas Monitoramento de Bacias Experimentais. p.171. Tese (Doutorado) - Universidade Estadual de Campinas (UNICAMP). Campinas, 2000.

VIESSMAN JUNIOR, W.; KNAPP, J.W.; LEWIS, G.L. (1977). Introduction to Hydrology. Harper e Row Publishers, New York, $2^{\mathrm{a}}$ ed., p.704.

WILKEN, P.S. (1978). Engenharia de Drenagem Superficial, CETESB, São Paulo, p.477.

WILSON, P.S. (1983). Engineering hydrology. Macmillan, London, $3^{\mathrm{a}}$ ed., p.309. 


\section{OBRAS CONSULTADAS}

AZEVEDO NETTO, J.M. (1969). Manual de Hidráulica. 5a edição revista e ampliada, Editora Edgard Blücher Ltda, Volume II: 382-825.

BARTH, R.T. (1997). Planos Diretores em Drenagem Urbana: Proposição de Medidas para sua Implementação. São Paulo. Tese (Doutorado) - Escola Politécnica. Departamento de Engenharia Hidráulica e Sanitária, Universidade de São Paulo.

BACIA ESCOLA (2002). Disponível em: <http://baciaescola.hpg.ig.com.br/html. Acesso em 03 de abril de 2003.

CETESB (1980). Drenagem Urbana: Manual de Projeto. Departamento de Águas e Energia Elétrica e Companhia de Tecnologia de Saneamento Ambiental. $2^{\mathrm{a}}$ ed. corrigida. DAEE/CETESB. São Paulo.

CORDEIRO, J.S.; VAZ FILHO, P. (1999). Gerenciamento de Sistemas de Drenagem Urbana - uma necessidade cada dia mais intensa in Anais do XIII Simpósio Brasileiro de Recursos Hídricos.

FONTES, A.R.M. (2000) - Estudo Analítico da Morfologia Urbana no Processo de Urbanização Visando o Planejamento de Sistema de Drenagem na Cidade de São Carlos. São Carlos. Dissertação (Mestrado). - Curso de Pós-Graduação em Engenharia Urbana - UFSCAR.

GENZ, F. (1994). Parâmetros para a Previsão e Controle de Cheias Urbanas. Porto Alegre: UFRGS Dissertação (Mestrado) - Curso de Pós-Graduação em Recursos Hídricos e Saneamento Ambiental. D180.

LORANDI, R. (1981). Caracterização dos Solos das Áreas Urbanas e Suburbanas de São Carlos/SP e suas Aplicações. Tese (Doutorado). Apresentada a Escola Superior de Agricultura Luiz de Queiroz.

MACHADO, E.S.; RIGHETTO, A. M. (1981). Modelo Hidrológico Determinístico para Bacias Urbanas. Anais do IV Simpósio Brasileiro de Hidrologia e Recursos Hídricos, Volume 3: $561-580$.

MANUAL DE SANEAMENTO, CAPÍTULO 5. [...] drenagem. Um sistema geral de drenagem urbana é constituído pelos sistemas de macrodrenagem e microdrenagem. $\quad 5.2 \quad$ Importância $\quad[\ldots] . \quad$ Disponível em: 
$<$ http://www.funasa.gov.br/pub/manusane/mansan05.PDF. Acesso 10 de maio de 2003.

OLIVEIRA, R.C. (1999) - Medidas não Estruturais na Prevenção e Controle de Enchentes em Áreas Urbanas, como Subsídios para o Planejamento de Uso e Ocupação do Solo: Estudo de Caso - Bacia do Córrego do Gregório - São Carlos/SP. São Carlos. Dissertação (Mestrado) - Escola de Engenharia de São Carlos, Departamento de Hidráulica e Saneamento, Universidade de São Paulo.

PINTO, N.L.S. (1978). Hidrologia Básica. Edgar Blücher. Rio de Janeiro. Fundação Nacional de Material Escolar.

PINTO, N.L.S.; HOLTZ, A.C.T.; MASSUCCI, C.J.J. - Vazão de Dimensionamento de Bueiros. Rio de Janeiro, IPR, reimp. 1975. 56p (publ. 478).

PORTO, R.M. (2001). Hidráulica Básica. São Carlos, 2º ed., 2001, p.519.

PORTO, R.M.; RIGHETTO, A.M.. Análise Comparativa de Métodos Hidrológicos Simples em Drenagem Urbana - XI Simpósio Brasileiro de Recursos Hídricos. Recife, 7 a 12 de Novembro de 1995. Volume 3, página 505 - 514.

REBELATTO, D.A.N. (1991). A Influência do Processo de Ocupação do Solo na Bacia do Rio Gregório em São Carlo/SP, sobre a Incidência de Enchentes nas Áreas Próximas ao Mercado Municipal. São Carlos. Dissertação (Mestrado) - Escola de Engenharia de São Carlos - EESC, Universidade de São Paulo.

RIGHETTO, A.M.; PORTO, R.M.; VILLELA, S.M. (1993). Adequação de Metodologia para Estudos de Drenagem Urbana - Aplicação para a Cidade de São Carlos. Anais do X Simpósio Brasileiro de Recursos Hídricos. Gramado, Rio Grande do Sul, 7 a 12 de Novembro de 1993. Volume 3, página 505 - 514.

TASSI, R. (2002). Efeito dos Microreservatórios de Lote sobre a Macrodrenagem Urbana. Porto Alegre/RS. Dissertação (Mestrado) - Universidade Federal do Rio Grande do Sul - UFRGS, 142p.

TUCCI, C.E.M.; MARQUES, D.M.L..M. (2000). Avaliação e Controle da Drenagem Urbana. Porto Alegre: Ed. Universidade/UFRGS, Volume 1, $1^{\text {a }}$ edição, 558 p.

VILLELA, S.M.; MATTOS, A. (1975). Hidrologia básica. Ed. McGraw-Hill do Brasil, São Paulo. 